\title{
Mineralogy of phosphate accumulations in the Huber stock, Krásno ore district, Slavkovský les area, Czech Republic
}

\author{
Mineralogie akumulací fosfátů oblasti Huberova pně, rudní revír Krásno, \\ Slavkovský les, Česká republika
}

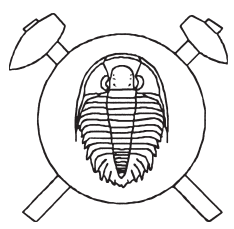

\author{
(91 figs, 31 tabs) \\ JIŘÍ SEJKORA ${ }^{1}-$ RADEK ŠKODA ${ }^{2}-$ PETR ONDRUŠ $^{3}-$ PAVEL BERAN $^{4}-$ CTIBOR SÜSSER $^{5}$ \\ ${ }^{1}$ Department of Mineralogy and Petrology, National Museum, Václavské nám. 68, CZ-115 79 Praha 1, Czech Republic \\ 2 Institute of Geological Sciences, Masaryk University, Kotlárská 2, CZ-611 37, Brno, Czech Republic \\ 3 Biskupský dvi̊r 2, CZ-110 00 Praha 1, Czech Republic \\ ${ }^{4}$ Regional Museum Sokolov, Zámecká 1, Sokolov, CZ-356 00, Czech Republic \\ 5 Karla Čapka 1357, Sokolov, CZ-356 01, Czech Republic
}

\begin{abstract}
The present detailed research is focused on minerals of phosphate accumulations collected in the Huber open pit and at the $5^{\text {th }}$ level of the Huber shaft, Krásno ore district, Slavkovský les area, Czech Republic. The following minerals have been identified at the studied localities: benyacarite, beraunite, cacoxenite, chalcosiderite, crandallite, dufrénite, earlshannonite, fluellite, fluorapatite, frondelite, goyazite, isokite, kolbeckite, leucophosphite, morinite, natrodufrénite, phosphosiderite, rockbridgeite, strengite, triplite, turquoise, vivianite, wavellite, waylandite, whitmoreite and zwieselite. A brief review of evolution of the phosphate mineral associations at the two studied localities is presented.
\end{abstract}

Key words: Huber stock; Krásno near Horní Slavkov; Slavkovský les area; greisen; phosphate minerals; mineralogy; X-ray powder diffraction data; chemical data.

\section{Introduction}

Phosphate accumulations of variable size represent a relatively common minor component of greisen bodies and associated quartz veins (Beran - Sejkora 2006). Their occurrence in greisen is localized in masses of white compact quartz, showing at places coarse-grained structure. Our research included a detailed study of phosphate accumulations exposed at various places of the floor of the Huber open pit. The accumulations vary in size from several millimetres up to $30 \mathrm{~cm}$. Late hydrothermal to probably supergene alterations are a characteristic feature.

The second set of samples studied comes from a welldocumented phosphate accumulation encountered at the $5^{\text {th }}$ level of the Huber shaft of the Stannum mine. No indications of historical mining have been found in this subarea. The crossing of P-5025030 and M-5025034 galleries exposed an irregular mass of white compact quartz. The observed part of this quartz body was triangular in plan, with dimensions of 10 by 5 to $6 \mathrm{~m}$, sited in greisen and in greisenized granite. One meter wide mass of coarse-grained topaz greisen, at places replaced by hematite and carrying oxidic Bi minerals, was exposed in the margin of the quartz mass in the M-5025034 gallery. Phosphate masses consisting of dominant fluorapatite and triplite from $10 \mathrm{~cm}$ to $1 \mathrm{~m}$ in size were excentrically located in white quartz mass at the right side of the same gallery. Aggregates of dark Fe-Mn phosphates with predominating frondelite occurred along contacts of phosphate accumulations with white quartz and cavernous corroded portions carrying crystals of younger phosphates (strengite, turquoise-chalcosiderite etc.). For comparison, two historical museum samples have been studied: NMCR
P1N 18.583 collected by F. X. Zippe before 1842 and sample 18.585 collected by V. Wraný before 1902). The samples with original labels "triplite, Horní Slavkov" probably come from the Gellnauer vein system, as indicated by the time of collection.

Beran (1999) described other large phosphate accumulations from the VIII ${ }^{\text {th }}$ level of the Schnöd stock. At this place, white quartz carried $1 \mathrm{~m}$ large triplite blocks associated with fluorapatite. The phosphate masses were deformed and partly brecciated. At the $\mathrm{X}^{\text {th }}$ level of the same mine triplite aggregates (up to some $\mathrm{dm}$ in size) occurred in association with fluorapatite and siderite. However, no samples were available for our study from these occurrences.

\section{Methods of mineral identification}

The surface morphology of samples was studied with the optical microscope Nikon SMZ1500 in combination with the digital camera Nikon DXM1200F, used for photography in incadescent light. Detailes of surface morphology were studied in secondary electron images using the scanning electron microscopes Jeol JSM T-20 (Z. Mach, Institute of fine ceramics, Karlovy Vary) and Jeol JSM6380 (J. Sejkora and J. Plášil, Faculty of Science, Charles University, Prague).

If not stated otherwise, all minerals described in this paper were identified by X-ray powder diffraction analysis. To minimize complicated shape of background due to classic glass sample holder, the samples studied were placed on the surface of flat silicon wafer from suspension in ethanol. Step-scanned powder diffraction data were collected using following instruments: 
HZG4-AREM/Seifert diffractometer (National Museum, Prague) with a copper tube was operated at high-voltage $50 \mathrm{kV}$ and tube current of $40 \mathrm{~mA}$; and Philips X'Pert MPD diffractometer (Czech Geological Survey, Prague) with a metallo-ceramic copper tube was operated at highvoltage of $40 \mathrm{kV}$ and tube current of $40 \mathrm{~mA}$. A graphite secondary monochromator has been used to produce $\mathrm{CuK \alpha _{1 }} \alpha_{2}$ radiation. The results were processed using X-ray analysis software ZDS for DOS (Ondruš 1993), Bede ZDS Search/Match ver. 4.5 (Ondruš - Skála 1997); unit-cell parameters were refined by program of Burnham (1962) and by program FullProf (Rodríguez - Carvajal 2005).

Quantitative chemical data were collected with the electron microprobe Cameca SX 100 (J. Sejkora and R. Škoda, Laboratory of electron microscopy and microanalysis of Masaryk University and Czech Geological Survey, Brno). Studied samples were mounted in the epoxide resin discs and polished. The polished surfaces were coated with carbon layer $250 \AA$ thick. Wavelength dispersion mode and operating voltage of $15 \mathrm{kV}$ were used in all analyses. The beam current and diameter were adjusted to stability of analyzed phases under the electron beam. Stable phases were analyzed using $20 \mathrm{nA}$ current and $2 \mu \mathrm{m}$ beam diameter. Less stable and highly hydrated minerals were analyzed using 10-4 nA and $10-30 \mu \mathrm{m}$ beam diameter. For smaller aggregates $(<10 \mu \mathrm{m})$ of unstable minerals the beam diameter was as large as possible and the applied beam current was only 1-2 nA. The sequence of analyzed elements was adjusted to particular composition of the analyzed mineral. Volatile and major elements were analyzed first, followed by stable, minor and trace elements. Elevated analytical totals of minerals containing a large amount of hydroxyl group or crystal water are generally caused by two factors: a) water evaporation under high vacuum conditions, well documented by collapsed crystals; b) water evaporation due to heating of the analyzed spot by electron beam. The dehydrated domain is seen as a notably brighter spot in backscattered electron images. Lower analytical totals for some samples are primarily caused by their porous nature or by poorly polished surface of soft or cryptocrystalline minerals.

In order to minimize peak overlapping the following analytic lines and crystals were selected: $\mathrm{K} \alpha$ lines: F (PC1, fluorapatite/topaz), Mg (TAP, forsterite), Na (TAP, albite), Al (TAP, sanidine), As (TAP, InAs), Si (TAP, sanidine), Cu (TAP, dioptase), K (PET, sanidine), $\mathrm{P}$ (PET, fluorapatite) Ca (PET, andradite), S (PET, barite), Ti (PET, TiO), Cl (PET, vanadinite), Fe (LIF, andradite), Mn (LIF, rhodonite), Ni (LIF, NiO), Zn (LIF, ZnO); L $\alpha$ lines: Y (TAP, YAG), Sr (PET, $\left.\mathrm{SrSO}_{4}\right), \mathrm{La}(\mathrm{PET}$, $\left.\mathrm{LaB}_{6}\right), \mathrm{Ce}\left(\mathrm{PET}, \mathrm{CeAl}_{2}\right), \mathrm{Sm}\left(\mathrm{LIF}, \mathrm{SmF}_{3}\right)$; Lß lines: $\mathrm{Ba}$ (PET, benitoite), $\operatorname{Pr}\left(\mathrm{LIF}, \mathrm{PrF}_{3}\right), \mathrm{Nd}$ (LIF, $\left.\mathrm{NdF}_{3}\right) ; \mathrm{M} \alpha$ lines: $\mathrm{Th}\left(\mathrm{PET}, \mathrm{ThO}_{2}\right), \mathrm{Pb}$ (PET, vanadinite); $\mathrm{MB}$ lines: Bi (PET, metallic Bi), U (PET, metallic U). Peak counting times $(\mathrm{CT})$ were 10 to $20 \mathrm{~s}$ for main elements and
30 to $60 \mathrm{~s}$ for minor and trace elements. CT for each background was $1 / 2$ of peak time. In case that background was measured only one side of the peak, the counting time was the same as counting on the peak. As far as possible, elements present in minor and trace abundances were measured with highly sensitive crystals LPET a LLIF. Raw intensities were converted to the concentrations using automatic PAP (Pouchou - Pichoir 1985) matrix correction software package.

Accurate determination of fluorine content in some of the studied phases is important. Where possible, determination of fluorine was verified by measuring peak area (integrated intensity); however, this procedure cannot be applied to triplite-like and apatite-like minerals. This control was done irrespective of the note by Raundsep (1995) that with multilayer crystal monochomators (PC1) the effect of matrix is minimal. Fluorine contents measured by the two methods are closely similar.

\section{Review of identified mineral species}

\section{Benyacarite $\mathrm{KMn}_{2}^{2+} \mathrm{Fe}_{2}^{3+}{ }_{2} \mathrm{Ti}\left(\mathrm{PO}_{4}\right)_{4}(\mathrm{OH}, \mathrm{F})_{3} \cdot 15 \mathrm{H}_{2} \mathrm{O}$}

The rare mineral has been found in small cavities in frondelite from phosphate acumulation at the $5^{\text {th }}$ level of the Huber shaft. Benyacarite forms small brittle and imperfectly developed crystals $0.1 \mathrm{~mm}$ in maximum size. The mineral shows one perfect cleavage (Fig. 1) and a greasy lustre.

Owing to small size of the crystals, the Ti-rich Fe-Mn phosphate from Krásno has been identified as a mineral close to benyacarite only on the basis of quantitative chemical analyses (Table 1). After including the theoretical content of $\mathrm{H}_{2} \mathrm{O}$ (c. 32 wt.\%) the chemical analyses show high totals in the range of 116-120 wt.\%. Fransolet et al. (1984) found in the course of analysis of the structurally related mineral mantienneite dehydration in

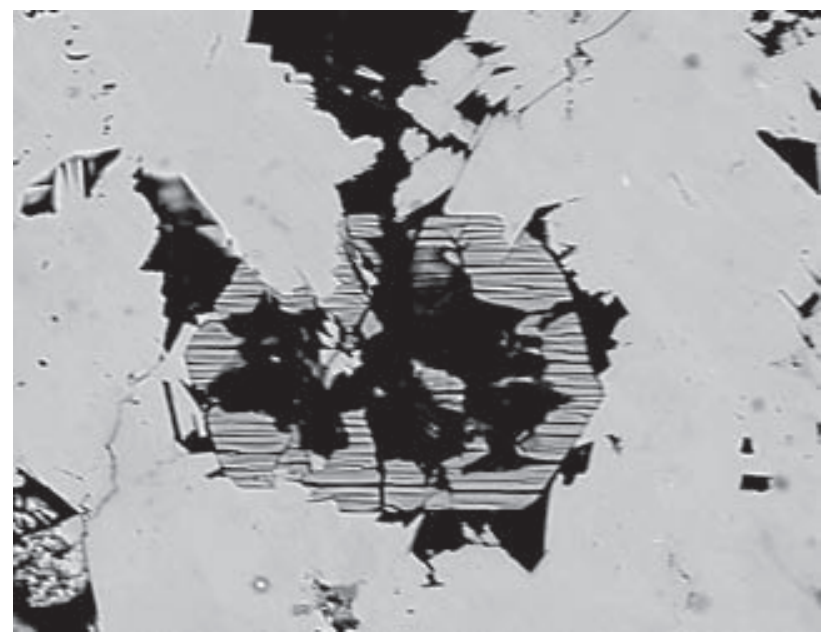

Fig. 1 Imperfect benyacarite crystals in a cavity in frondelite aggregate; dehydration in vacuum resulted in fracturing of the crystal along a single set of perfect cleavages. Width of photo $200 \mu \mathrm{m}$. Cameca SX100, BSE photograph by J. Sejkora and R. Škoda. 
Table 1 Chemical composition of benyacarite (in wt. \%)

\begin{tabular}{|c|c|c|c|c|c|c|c|c|}
\hline & 1 & $\begin{array}{c}\text { Krásno* } \\
2 \\
\end{array}$ & 3 & mean & $\begin{array}{c}\text { Cerro Blanco } \\
\text { Argentina*2 }\end{array}$ & $\begin{array}{l}\text { Hagendorf } \\
\text { Germany*3 }\end{array}$ & $\begin{array}{l}\text { Chelyabinsk } \\
\text { Russia*4 }\end{array}$ & $\begin{array}{l}\text { theor. } \\
\quad * 5\end{array}$ \\
\hline $\mathrm{Na}_{2} \mathrm{O}$ & 0.12 & 0.02 & 0.05 & 0.06 & 0.20 & & & \\
\hline $\mathrm{K}_{2} \mathrm{O}$ & 4.75 & 4.21 & 3.58 & 4.18 & 1.60 & 3.91 & 2.11 & 4.66 \\
\hline $\mathrm{MnO}$ & 14.03 & 15.55 & 15.89 & 15.16 & 11.20 & 9.63 & 8.06 & 14.05 \\
\hline $\mathrm{CaO}$ & & & & & 0.10 & 0.34 & & \\
\hline $\mathrm{PbO}$ & 0.14 & 0.00 & 0.09 & 0.08 & & & & \\
\hline $\mathrm{CuO}$ & 0.00 & 0.07 & 0.08 & 0.05 & & & & \\
\hline $\mathrm{BaO}$ & 0.32 & 0.03 & 0.23 & 0.19 & & & & \\
\hline $\mathrm{MgO}$ & 0.69 & 0.52 & 0.45 & 0.55 & 0.30 & & 3.51 & \\
\hline $\mathrm{ZnO}$ & 0.10 & 0.00 & 0.33 & 0.15 & & & & \\
\hline $\mathrm{FeO}^{*}$ & 0.73 & 0.90 & 0.49 & 0.71 & 3.38 & 5.01 & 0.00 & \\
\hline $\mathrm{Fe}_{2} \mathrm{O}_{3} *$ & 9.98 & 10.97 & 11.74 & 10.90 & 10.32 & 9.91 & 9.18 & 15.81 \\
\hline $\mathrm{Al}_{2}^{2} \mathrm{O}_{3}$ & 3.59 & 2.43 & 2.32 & 2.78 & 0.70 & 1.60 & 4.25 & \\
\hline $\mathrm{As}_{2} \mathrm{O} 5$ & 0.00 & 0.00 & 0.06 & 0.02 & & & & \\
\hline $\mathrm{P}_{2} \mathrm{O}_{5}$ & 35.14 & 35.10 & 36.68 & 35.64 & 28.10 & 28.12 & 29.37 & 28.11 \\
\hline $\mathrm{TiO}_{2}$ & 14.05 & 14.85 & 15.63 & 14.84 & 12.30 & 11.32 & 8.54 & 7.91 \\
\hline $\mathrm{F}$ & 0.35 & 0.23 & 0.28 & 0.29 & 1.50 & & & \\
\hline $\mathrm{O}-\mathrm{F}_{2}$ & -0.15 & -0.10 & -0.12 & -0.12 & -0.63 & 0.00 & 0.00 & \\
\hline $\mathrm{H}_{2} \mathrm{O}^{2} * *$ & 31.86 & 31.88 & 32.18 & 31.98 & 29.51 & 30.21 & 31.41 & 29.45 \\
\hline total & 115.70 & 116.65 & 119.95 & 117.44 & 98.58 & 100.05 & 96.43 & 100.00 \\
\hline $\mathrm{Na}$ & 0.032 & 0.005 & 0.012 & 0.016 & 0.065 & 0.000 & 0.000 & \\
\hline $\mathrm{K}$ & 0.815 & 0.723 & 0.588 & 0.707 & 0.343 & 0.838 & 0.433 & \\
\hline total $\mathrm{M}^{1+}$ & 0.847 & 0.728 & 0.601 & 0.723 & 0.408 & 0.838 & 0.433 & \\
\hline $\mathrm{Ca}$ & 0.000 & 0.000 & 0.000 & 0.000 & 0.018 & 0.061 & 0.000 & \\
\hline $\mathrm{Ba}$ & 0.017 & 0.001 & 0.012 & 0.010 & 0.000 & 0.000 & 0.000 & \\
\hline $\mathrm{Mg}$ & 0.138 & 0.104 & 0.086 & 0.109 & 0.075 & 0.000 & 0.842 & \\
\hline $\mathrm{Pb}$ & 0.005 & 0.000 & 0.003 & 0.003 & 0.000 & 0.000 & 0.000 & \\
\hline $\mathrm{Cu}$ & 0.000 & 0.007 & 0.008 & 0.005 & 0.000 & 0.000 & 0.000 & \\
\hline $\mathrm{Mn}^{2+}$ & 1.598 & 1.773 & 1.732 & 1.701 & 1.595 & 1.371 & 1.098 & \\
\hline $\mathrm{Zn}$ & 0.010 & 0.000 & 0.031 & 0.014 & 0.000 & 0.000 & 0.000 & \\
\hline $\mathrm{Fe}^{2+}$ & 0.082 & 0.102 & 0.052 & 0.078 & 0.476 & 0.705 & & \\
\hline total $\mathrm{M}^{2+}$ & 1.850 & 1.987 & 1.924 & 1.920 & 2.164 & 2.136 & 1.940 & \\
\hline $\mathrm{Al}$ & 0.569 & 0.386 & 0.351 & 0.434 & 0.139 & 0.317 & 0.806 & \\
\hline $\mathrm{Fe}^{3+}$ & 1.010 & 1.111 & 1.137 & 1.087 & 1.306 & 1.253 & 1.111 & \\
\hline $\mathrm{Ti}^{4+}\left(\right.$ in $\left.\mathrm{M}^{3+}\right)$ & 0.421 & 0.503 & 0.512 & 0.479 & 0.555 & 0.430 & 0.033 & \\
\hline total $\mathrm{M}^{3+}$ & 2.000 & 2.000 & 2.000 & 2.000 & 2.000 & 2.000 & 1.950 & \\
\hline $\mathrm{Ti}^{4+}$ (all) & 1.421 & 1.503 & 1.512 & 1.479 & 1.555 & 1.430 & 1.033 & \\
\hline $\mathrm{Ti}^{4+}\left(\right.$ in $\left.\mathrm{M}^{4+}\right)$ & 1.000 & 1.000 & 1.000 & 1.000 & 1.000 & 1.000 & 1.000 & \\
\hline $\mathrm{As}^{5+}$ & 0.000 & 0.000 & 0.004 & 0.001 & 0.000 & 0.000 & 0.000 & \\
\hline $\mathrm{P}^{5+}$ & 4.000 & 4.000 & 3.996 & 3.999 & 4.000 & 4.000 & 4.000 & \\
\hline total $\mathrm{P}+\mathrm{As}$ & 4.000 & 4.000 & 4.000 & 4.000 & 4.000 & 4.000 & 4.000 & \\
\hline $\mathrm{F}$ & 0.148 & 0.098 & 0.115 & 0.120 & 0.798 & 0.000 & 0.000 & \\
\hline $\mathrm{H}$ & 32.820 & 33.109 & 32.842 & 32.929 & 32.495 & 33.541 & 32.192 & \\
\hline $\mathrm{OH}$ & 2.820 & 3.107 & 2.845 & 2.923 & 2.494 & 3.541 & 2.197 & \\
\hline $\mathrm{OH}+\mathrm{F}$ & 2.967 & 3.206 & 2.960 & 3.043 & 3.291 & 3.541 & 2.197 & \\
\hline $\mathrm{H}_{2} \mathrm{O}$ & 15.000 & 15.001 & 15.000 & 15.003 & 15.001 & 15.000 & 14.998 & \\
\hline
\end{tabular}

$* 1$ - this paper; *2 - Demartin et al. (1993); *3 - Pollmann et al. (1998); *4 - Kydryashova - Rozhdestvenskaya (1991); *5 - theoretical composition of benyacarite $\mathrm{KMn}_{2} \mathrm{Fe}_{2} \mathrm{Ti}\left(\mathrm{PO}_{4}\right)_{4}(\mathrm{OH})_{3} .15 \mathrm{H}_{2} \mathrm{O}$

Empirical formulas were calculated on the basis of $\mathrm{P}+\mathrm{As}=4.00$.

* $-\mathrm{Fe}_{\text {tot }}$ calculated to $\mathrm{FeO}$ and $\mathrm{Fe}_{2} \mathrm{O}_{3}$ on the basis of $\mathrm{M}^{3+}$ and $\mathrm{M}^{2+}$ occupancy of the general formula

$* *-\mathrm{H}_{2} \mathrm{O}$ content calculated from the general formula $\left(\mathrm{H}_{2} \mathrm{O}=15.00\right)$ and charge balance

the vacuum of electron microanalyzer; at the same time, dehydration thermal analysis indicates that $\mathrm{H}_{2} \mathrm{O}$ begins to escape under relatively low temperatures, including loss of 15 wt. $\% \mathrm{H}_{2} \mathrm{O}$ below $180{ }^{\circ} \mathrm{C}$. The high totals of analyses, after inclusion of the theoretical content of $\mathrm{H}_{2} \mathrm{O}$, can be explained by dehydration of the studied mineral during preparation of the sample for analysis in vacuum. These conclusions are supported by the presence of regular "dehydration" fractures in the studied sample (Fig. 1).

Data published by Fransolet et al. (1984) and Peacor et al. (1984) can be used to define a general formula
$\mathrm{M}^{1+} \mathrm{M}_{2}^{2+}{ }_{2} \mathrm{M}_{2}^{3+} \mathrm{M}^{4+}\left(\mathrm{PO}_{4}\right)_{4}(\mathrm{OH}, \mathrm{F})_{3} \cdot 15 \mathrm{H}_{2} \mathrm{O}$ for benyacarite and related minerals (mantienneite, paulkerrite). The $\mathrm{M}^{1+}$ position of benyacarite from Krásno contains K (0.590.82 apfu) and minor Na. Demartin et al. (1993) supposed on the basis of crystal structure study of benyacarite that $\mathrm{K}$ occupies cavities existing within the network of octahedra and tetrahedra, in a similar way as $\mathrm{H}_{2} \mathrm{O}$ molecules, and he proposed, in difference with other authors, two $\mathrm{M}^{1+}$ positions $p f u$ (with $\mathrm{H}_{2} \mathrm{O}>\mathrm{K}$ ). However, no mineral related to benyacarite contains in the $\mathrm{M}^{1+}$ position $(\mathrm{K}+\mathrm{Na})$ higher than 1 apfu (the known maximum is 0.95 


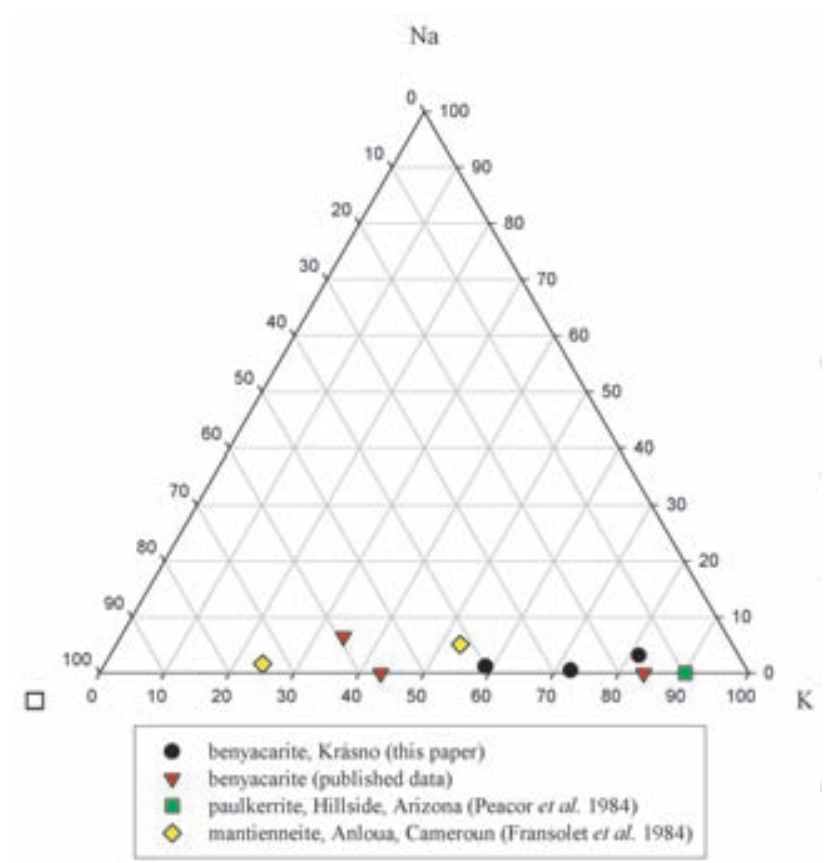

Fig. 2 Ternary plot of $\mathrm{M}^{1+}$ site occupancy (atomic ratio) in benyacarite-related minerals; $\square$ - vacancy or $\mathrm{H}_{2} \mathrm{O}$. The published benyacarite data are from Cerro Blanco, Argentina (Demartin et al. 1993); Hagendorf, Germany (Pollmann et al. 1998); Chelyabinsk, Russia (Kydryashova - Rozhdestvenskaya 1991).

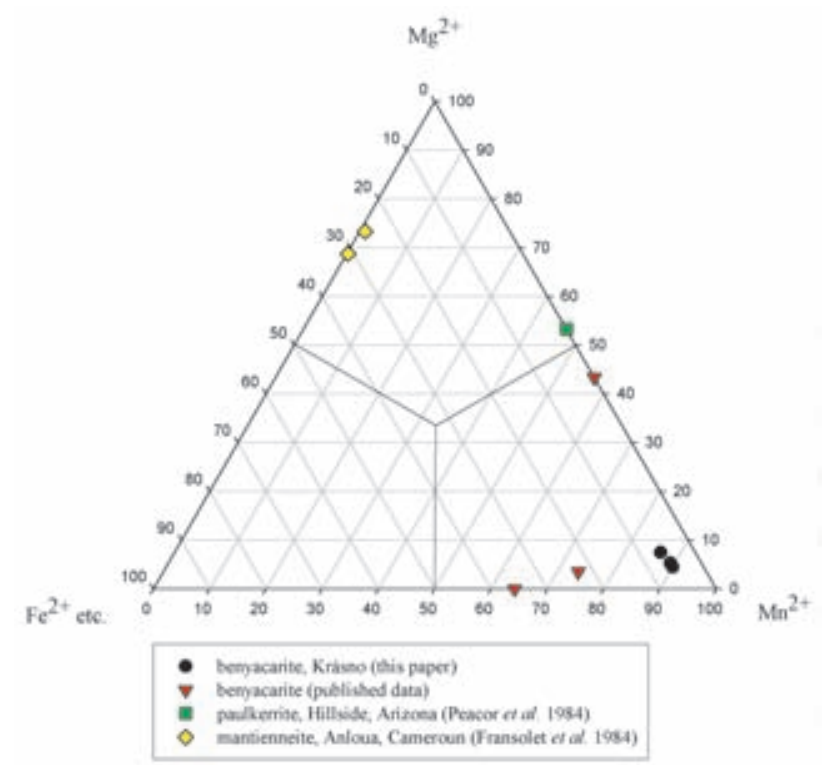

Fig. 3 Ternary plot of $\mathrm{M}^{2+}$ site occupancy (atomic ratio) in benyacarite-related minerals; published benyacarite data are from Cerro Blanco, Argentina (Demartin et al. 1993); Hagendorf, Germany (Pollmann et al. 1998) and Chelyabinsk, Russia (Kydryashova-Rozhdestvenskaya 1991). apfu). Alternatively, besides the $\mathrm{H}_{2} \mathrm{O}$ content (derived solely from the crystal structure study), Fransolet et al. (1984) and Peacor et al. (1984) prefer the role of vacancies. According to the current rules of the mineralogical system two additional mineral species (Table 2) would be possible to define on the basis of occupancy of the $\mathrm{M}^{1+}$ site (Fig. 2). Benyacarite from Krásno exhibits $\mathrm{K}$ contents in the $\mathrm{M}^{1+}$ position similar to the mineral from Hagendorf (Pollmann et al. 1998). The other published analyses of this mineral contain only $0.41-0.43$ apfu $\mathrm{K}+\mathrm{Na}$.

In contrast to published benyacarite analyses (Fig. 3), the material from Krásno has the $\mathrm{M}^{2+}$ site strongly dominated by Mn (1.60-1.78) apfu (paulkerrite and mantienneite are $\mathrm{Mg}$-dominated). Other elements occur in minor quantities - Mg 0.09-0.14apfu, $\mathrm{Fe}^{2+}$ 0.05-0.10apfu,

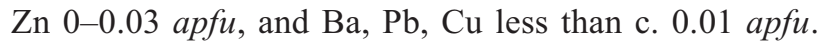
In the site $\mathrm{M}^{3+}$, occupied mainly by $\mathrm{Fe}^{3+}$ (1.01-1.14 apfu), significant quantities of $\mathrm{Al}$ (range of 0.35-0.57 apfu) and $\mathrm{Ti}^{4+}(0.42-0.51$ apfu $)$ were found. The site $\mathrm{M}^{4+}$ is occupied exclusively by $\mathrm{Ti}$ in all benyacarite-related minerals. Surplus Ti contents, reported in majority of published analyses of benyacarite-related minerals, enter the site $\mathrm{M}^{3+}$ as indicated above (Fig. 4).

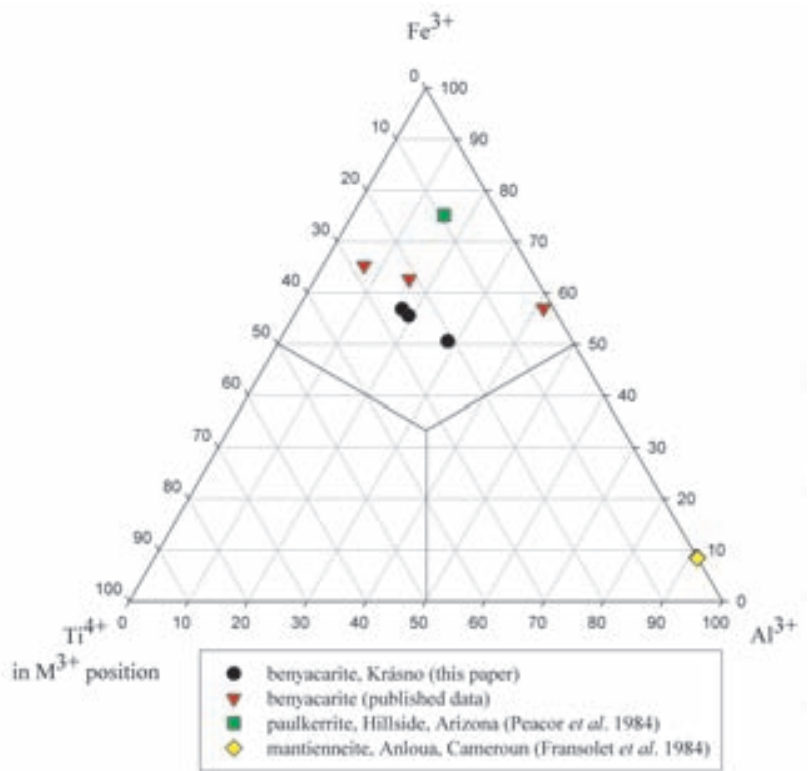

Fig. 4 Ternary plot of $\mathrm{M}^{3+}$ position occupancy (atomic ratio) in benyacarite-related minerals; published benyacarite data are from Cerro Blanco, Argentina (Demartin et al. 1993); Hagendorf, Germany (Pollmann et al. 1998) and Chelyabinsk, Russia (Kydryashova - Rozhdestvenskaya 1991).

Table 2 Possible new mineral species related to benyacarite

\begin{tabular}{|llllll|}
\hline & & $\mathrm{M}^{1+}$ & $\mathrm{M}^{2+}$ & $\mathrm{M}^{3+}$ & $\mathrm{M}^{4+}$ \\
\hline benyacarite & Demartin et al. $(1998)$, & $\square$ or $\mathrm{H}_{2} \mathrm{O}$ & $\mathrm{Mn}$ & $\mathrm{Fe}$ & $\mathrm{Ti}$ \\
& Kydryashova - Rozhdestvenskaya (1991) & & & & \\
new & Pollmann et al. $(1998)$; this paper & $\mathrm{K}$ & $\mathrm{Mn}$ & $\mathrm{Fe}$ & $\mathrm{Ti}$ \\
paulkerrite & Peacor et al. $(1984)$ & $\mathrm{K}$ & $\mathrm{Mg}$ & $\mathrm{Fe}$ & $\mathrm{Ti}$ \\
mantienneite & Fransolet et al. $(1984)$ - part of analyses & $\mathrm{K}$ & $\mathrm{Mg}$ & $\mathrm{Al}$ & $\mathrm{Ti}$ \\
new & Fransolet et al. $(1984)$ - part of analyses & $\square$ & $\mathrm{Mg}$ & $\mathrm{Al}$ & $\mathrm{Ti}$ \\
\hline
\end{tabular}


The anion group in benyacarite-related minerals contains almost exclusively P. The studied sample from Krásno contains minor local As to max. of 0.004 apfu. Fluorine substitutes for a part of $(\mathrm{OH})$ anions in some benyacarite-related minerals (Fig. 5). In the sample from Krásno F contents correspond to 0.10 to 0.15 apfu.

On the basis of site occupancy, the empirical formula of benyacarite from Krásno on the $4(\mathrm{P}+\mathrm{As}) p f u$ content correspond to $\left(\mathrm{K}_{0.71} \mathrm{Na}_{0.02} \square_{0.27}\right)_{\Sigma 1.00}\left(\mathrm{Mn}_{1.70} \mathrm{Mg}_{0.11} \mathrm{Fe}_{0.08} \mathrm{Zn}_{0.01}\right.$ $\left.\mathrm{Ba}_{0.01} \mathrm{Cu}_{0.01}\right)_{\Sigma 1.92}\left(\mathrm{Fe}_{1.09} \mathrm{Ti}_{0.48} \mathrm{Al}_{0.43}\right)_{\Sigma 2.00} \mathrm{Ti}_{1.00}\left(\mathrm{PO}_{4}\right)_{4.00}\left(\mathrm{OH}_{2.92} \mathrm{~F}_{0.12}\right)_{\Sigma 3.04}$ . $15 \mathrm{H}_{2} \mathrm{O}$.

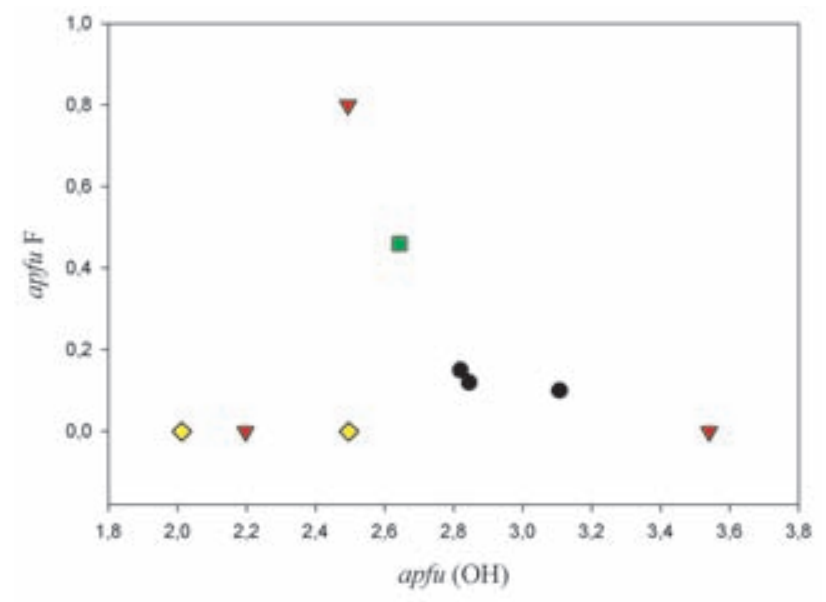

- benyacarite, Krảsno (this paper)

- benyacarite (published data)

- paulkerrite, Hillside, Arizona (Peacor ef al. 1984)

$\checkmark$ mantienneite, Anloua, Cameroun (Fransolet et af. 1984)

Fig. 5 A plot of $a p f u(\mathrm{OH}) v s$. apfu $\mathrm{F}$ in benyacarite-related minerals. The published benyacarite data are from Cerro Blanco, Argentina (Demartin et al. 1993); Hagendorf, Germany (Pollmann et al. 1998) and Chelyabinsk, Russia (Kydryashova - Rozhdestvenskaya 1991).

\section{Beraunite $\mathrm{Fe}^{2+} \mathrm{Fe}_{5}^{3+}\left(\mathrm{PO}_{4}\right)_{4}(\mathrm{OH})_{5} \cdot 6 \mathrm{H}_{2} \mathrm{O}$}

Beraunite was first described from Krásno (Huber open pit) by Korbel (1991) as spheroidal radiating aggregates, up to $3 \mathrm{~mm}$ in diameter, showing a dirty green colour. The study cited gives also X-ray powder diffraction data and spectral analysis. Minor contents of $\mathrm{Si}, \mathrm{Al}, \mathrm{As}$ and $\mathrm{Zn}$ are notable.

In the course of our study, $\mathrm{Zn}$ - and Al-rich beraunite have been found as long acicular crystals (Fig. 6), partly grouped in radiating aggregates up to $1 \mathrm{~cm}$ in size on samples from the Huber open pit. The mineral has a silvery to olive grey-green colour, grading to brown, and pearly lustre (with indications of cat's eye effect). Other samples carry porous, dark green aggregates with indistinct radiating and fibrous structure (Fig. 7), overgrown by abundant K-deficient leucophosphite, fluorapatite and microscopic aggregates of UNK3 (Sejkora et al. 2006). Brownish radiating aggregates up to $4 \mathrm{~mm}$ in diameter,

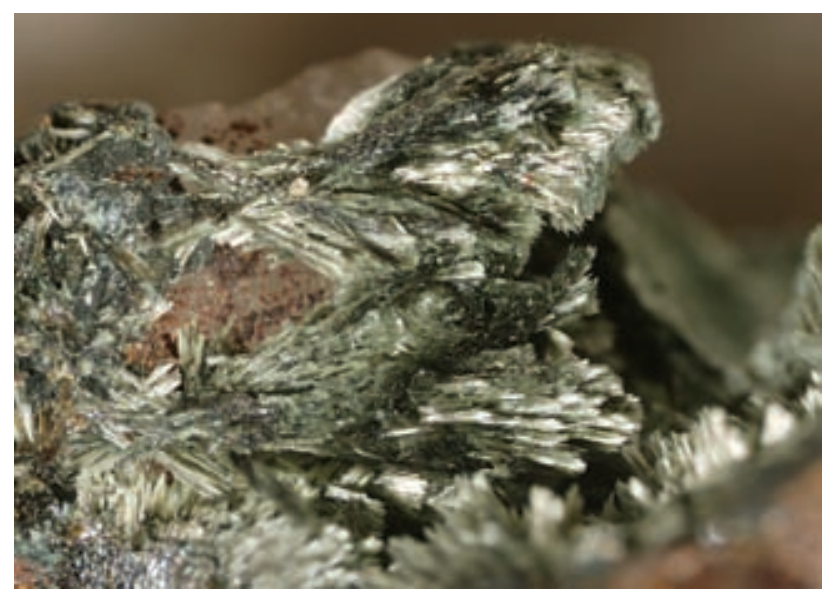

Fig. 6 Aggregates of acicular crystals of $\mathrm{Zn}$ - and Al-rich beraunite; Huber open pit, Krásno. Width of photo $5 \mathrm{~mm}$ Nicon SMZ1500 microphotography (J. \& E. Sejkora)

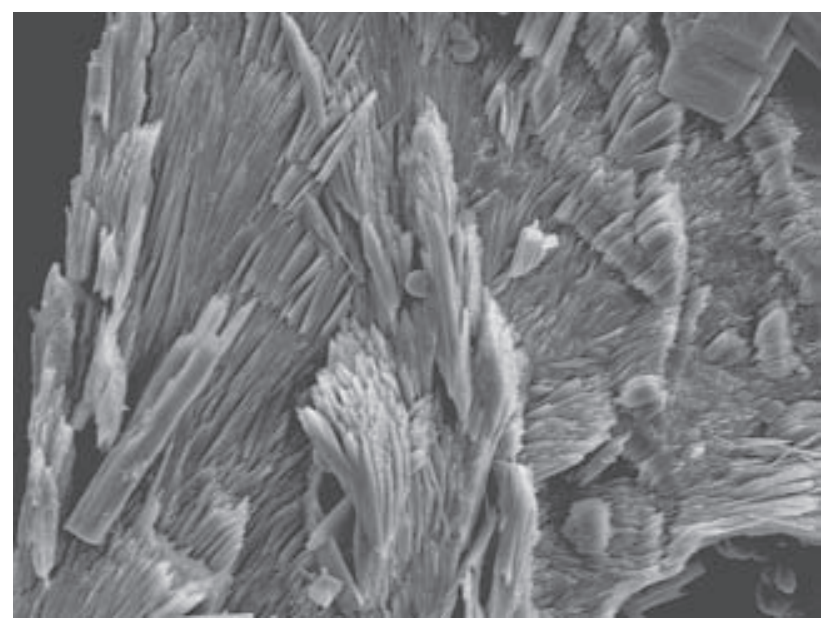

Fig. 7 Fibrous aggregate of $\mathrm{Zn}$ - and Al-rich beraunite, Huber open pit, Krásno. Width of photo $75 \mu \mathrm{m}$. SEM photograph by J. Sejkora.

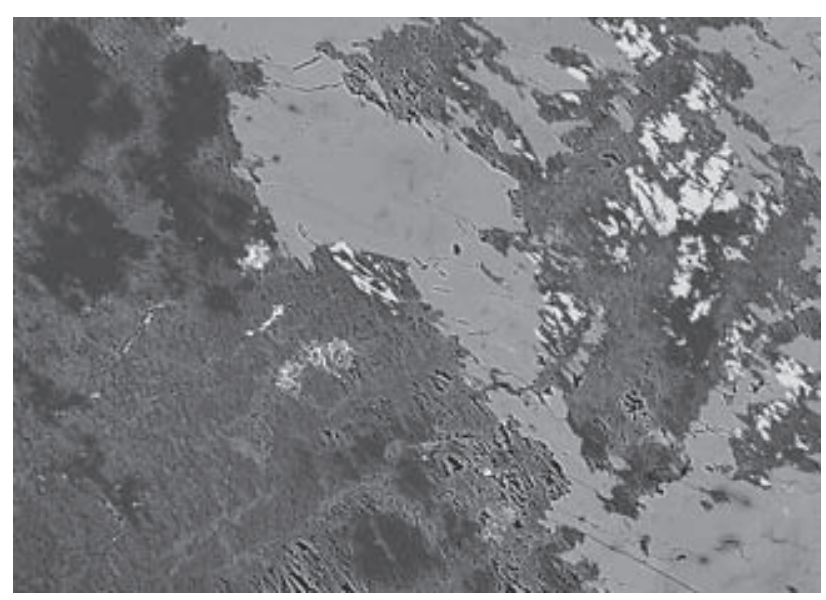

Fig. 8 Fibrous Mn-beraunite (grey) replacing older $\mathrm{Zn}$-rich rockbridgeite (light) and triplite (white). Mn-beraunite is itself partly altered to younger phoshosiderite (the darkest mineral). $5^{\text {th }}$ level of the Huber shaft. Width of photo $400 \mu \mathrm{m}$. Cameca SX100, BSE photograph by J. Sejkora and R. Škoda. 
Table 3 X-ray powder diffraction pattern of Zn- and Al-rich beraunite from Krásno

\begin{tabular}{|c|c|c|c|c|c|c|c|c|c|c|c|c|c|c|}
\hline$I_{r e l}$ & $d$ & $h$ & $k$ & $l$ & $I_{r e l}$ & $d$ & $h$ & $k$ & $l$ & $I_{r e l}$ & $d$ & $h$ & $k$ & $l$ \\
\hline 100 & 10.295 & 2 & 0 & 0 & 1 & 2.3079 & 4 & 2 & 0 & 1 & 1.7328 & 8 & 2 & 3 \\
\hline 5 & 9.594 & 0 & 0 & 2 & 2 & 2.2991 & -4 & 2 & 1 & 1 & 1.7297 & -8 & 2 & 4 \\
\hline 17 & 7.250 & -2 & 0 & 2 & 3 & 2.2838 & 4 & 2 & 1 & 1 & 1.7215 & -6 & 0 & 10 \\
\hline 3 & 6.808 & 2 & 0 & 2 & 1 & 2.2695 & 6 & 0 & 6 & 1 & 1.7158 & 12 & 0 & 0 \\
\hline 12 & 5.147 & 4 & 0 & 0 & 2 & 2.2584 & -4 & 2 & 2 & 1 & 1.7093 & -1 & 3 & 1 \\
\hline 1 & 4.865 & -1 & 1 & 1 & 2 & 2.2062 & 2 & 2 & 4 & 1 & 1.7077 & 1 & 3 & 1 \\
\hline 2 & 4.797 & 0 & 0 & 4 & 1 & 2.2062 & 7 & 1 & 4 & 1 & 1.7046 & 6 & 2 & 6 \\
\hline 2 & 4.468 & -1 & 1 & 2 & 2 & 2.0924 & -9 & 1 & 1 & 1 & 1.6837 & 10 & 0 & 6 \\
\hline 1 & 4.422 & 4 & 0 & 2 & 1 & 2.0917 & 9 & 1 & 0 & 2 & 1.6757 & -8 & 2 & 5 \\
\hline 2 & 4.412 & 1 & 1 & 2 & 1 & 2.0756 & 7 & 1 & 5 & 2 & 1.6696 & 3 & 3 & 0 \\
\hline 1 & 4.247 & 2 & 0 & 4 & 8 & 2.0632 & 6 & 2 & 0 & 1 & 1.6546 & 1 & 3 & 3 \\
\hline 1 & 4.126 & 3 & 1 & 0 & 3 & 2.0596 & -6 & 2 & 1 & 4 & 1.6491 & -3 & 3 & 2 \\
\hline 1 & 3.914 & 1 & 1 & 3 & 1 & 2.0329 & -6 & 2 & 2 & 2 & 1.6439 & 0 & 2 & 9 \\
\hline 8 & 3.740 & 3 & 1 & 2 & 1 & 1.9877 & 10 & 0 & 2 & 2 & 1.6358 & -2 & 2 & 9 \\
\hline 1 & 3.625 & -4 & 0 & 4 & 2 & 1.9856 & -6 & 2 & 3 & 1 & 1.6214 & 11 & 1 & 4 \\
\hline 1 & 3.529 & -3 & 1 & 3 & 1 & 1.9572 & 2 & 2 & 6 & 1 & 1.6095 & 3 & 3 & 3 \\
\hline 29 & 3.438 & 1 & 1 & 4 & 1 & 1.9536 & 4 & 2 & 5 & 1 & 1.6005 & -10 & 2 & 2 \\
\hline 1 & 3.432 & 6 & 0 & 0 & 1 & 1.9509 & 1 & 1 & 9 & 1 & 1.5885 & -4 & 2 & 9 \\
\hline 15 & 3.298 & -6 & 0 & 2 & 2 & 1.9422 & 6 & 2 & 3 & 1 & 1.5607 & 5 & 3 & 2 \\
\hline 2 & 3.220 & 5 & 1 & 0 & 1 & 1.9367 & -10 & 0 & 4 & 1 & 1.5345 & -2 & 2 & 10 \\
\hline 2 & 3.188 & -3 & 1 & 4 & 3 & 1.9239 & -3 & 1 & 9 & 1 & 1.5187 & -5 & 3 & 4 \\
\hline 8 & 3.169 & 6 & 0 & 2 & 2 & 1.9080 & -2 & 0 & 10 & 1 & 1.49630 & -4 & 2 & 10 \\
\hline 16 & 3.150 & 5 & 1 & 1 & 2 & 1.8970 & -4 & 2 & 6 & 1 & 1.48939 & -3 & 3 & 6 \\
\hline 3 & 3.110 & -2 & 0 & 6 & 1 & 1.8794 & 0 & 2 & 7 & 1 & 1.48017 & -5 & 3 & 5 \\
\hline 2 & 3.071 & 3 & 1 & 4 & 1 & 1.8698 & 6 & 2 & 4 & 1 & 1.47885 & -7 & 1 & 11 \\
\hline 5 & 3.069 & -1 & 1 & 5 & 1 & 1.8631 & -2 & 2 & 7 & 2 & 1.47082 & 3 & 3 & 6 \\
\hline 1 & 3.024 & 1 & 1 & 5 & 2 & 1.8504 & 10 & 0 & 4 & 1 & 1.46112 & 7 & 3 & 2 \\
\hline 3 & 2.865 & -3 & 1 & 5 & 2 & 1.8469 & 4 & 2 & 6 & 1 & 1.44172 & -2 & 2 & 11 \\
\hline 1 & 2.796 & -4 & 0 & 6 & 1 & 1.8204 & 7 & 1 & 7 & 1 & 1.43633 & -5 & 3 & 6 \\
\hline 3 & 2.714 & -1 & 1 & 6 & 1 & 1.8192 & -5 & 1 & 9 & 1 & 1.43569 & -3 & 3 & 7 \\
\hline 1 & 2.712 & 6 & 0 & 4 & 1 & 1.8124 & -8 & 0 & 8 & 1 & 1.43229 & -6 & 2 & 10 \\
\hline 2 & 2.677 & 1 & 1 & 6 & 1 & 1.8056 & -8 & 2 & 2 & 1 & 1.43202 & -7 & 3 & 4 \\
\hline 3 & 2.582 & 0 & 2 & 0 & 1 & 1.8010 & -1 & 1 & 10 & 1 & 1.43066 & -12 & 2 & 1 \\
\hline 15 & 2.575 & -3 & 1 & 6 & 1 & 1.7892 & 6 & 2 & 5 & 1 & 1.42905 & 12 & 2 & 0 \\
\hline 1 & 2.574 & 8 & 0 & 0 & 1 & 1.7829 & -10 & 0 & 6 & 1 & 1.41082 & -4 & 2 & 11 \\
\hline 3 & 2.528 & -5 & 1 & 5 & 1 & 1.7827 & 1 & 1 & 10 & 1 & 1.39868 & -1 & 3 & 8 \\
\hline 1 & 2.4476 & 8 & 0 & 2 & 1 & 1.7763 & 8 & 2 & 2 & 1 & 1.39177 & 1 & 3 & 8 \\
\hline 1 & 2.4142 & 2 & 2 & 2 & 1 & 1.7655 & -3 & 1 & 10 & 1 & 1.39010 & -7 & 1 & 12 \\
\hline 1 & 2.3690 & -2 & 0 & 8 & 1 & 1.7643 & -6 & 2 & 6 & 1 & 1.37565 & -9 & 3 & 1 \\
\hline 1 & 2.3442 & -2 & 2 & 3 & 1 & 1.7572 & 0 & 2 & 8 & 1 & 1.36738 & -5 & 1 & 13 \\
\hline 1 & 2.3299 & 7 & 1 & 3 & 1 & 1.7493 & -11 & 1 & 2 & & & & & \\
\hline 1 & 2.3240 & -3 & 1 & 7 & 1 & 1.7414 & 4 & 2 & 7 & & & & & \\
\hline
\end{tabular}

Table 4 Unit-cell parameters of beraunite (for monoclinic space group $C 2 / c$ )

\begin{tabular}{|c|c|c|c|c|c|}
\hline colour & $\begin{array}{l}\text { beraunite } \\
\text { green } \\
\text { this paper }\end{array}$ & $\begin{array}{c}\text { beraunite } \\
\text { green } \\
\text { Moore - Kampf (1992) }\end{array}$ & $\begin{array}{c}\text { Mn-beraunite } \\
\text { red } \\
\text { di Cossato et al. }(1989)\end{array}$ & $\begin{array}{l}\text { beraunite } \\
\text { green } \\
\text { Moore (1970) }\end{array}$ & $\begin{array}{c}\text { beraunite } \\
\text { red } \\
\text { Fanfani - Zanazzi (1967) }\end{array}$ \\
\hline $\mathrm{a}[\AA]$ & $20.630(6)$ & $20.953(5)$ & $20.760(3)$ & $20.80(3)$ & $20.646(5)$ \\
\hline $\mathrm{b}[\AA]$ & $5.164(2)$ & $5.171(1)$ & $5.153(1)$ & $5.156(3)$ & $5.129(7)$ \\
\hline c $[\AA]$ & $19.225(8)$ & $19.226(4)$ & $19.248(2)$ & $19.22(6)$ & $19.213(5)$ \\
\hline$\beta\left[^{\circ}\right]$ & $93.61(4)$ & $93.34(2)$ & $93.55(1)$ & $93.3(4)$ & $93.62(8)$ \\
\hline $\mathrm{V}\left[\AA^{3}\right]$ & 2044.0 & 2083.89 & 2055.13 & 2057.8 & 2030.5 \\
\hline
\end{tabular}

megascopically similar to frondelite, represent a rare example. The X-ray diffraction pattern obtained for $\mathrm{Zn}$ - and Al-rich beraunite (Table 3) and its refined unit-cell parameters (Table 4) are close the published data for this mineral.

Numerous samples from the $5^{\text {th }}$ level of the Huber mine carry fibrous aggregates, up to $200 \mu \mathrm{m}$, which extensively replace older rockbridgeite and triplite (Fig. 8). They in turn show alteration of variable intensity to the youngest phosphosiderite (Fig. 9). Fluorapatite and mem- bers of the rockbridgeite - frondelite series closely associated. This mineral phase could not be examined by $\mathrm{X}$-ray powder diffraction due to its small size. The similarity in chemical composition of the studied phase to Mn-rich beraunite, described by di Cossato et al. (1989) from Mangualde, Portugal, and its fibrous character, suggest that the mineral is probably Mn-rich beraunite. The chemical composition could also correspond to anomalously Mn-rich ludlamite, but this mineral is tabular, compact or granular. 


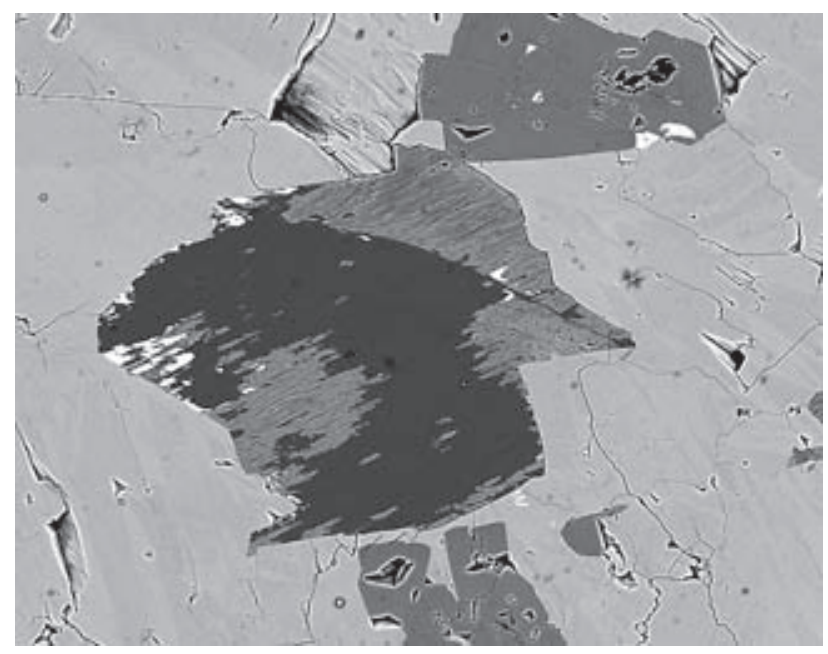

Fig. 9 Relics of fibrous Mn-rich beraunite aggregates (grey) intensively replaced by phosphosiderite (dark), intergrown in aggregates of $\mathrm{Zn}$-rich rockbridgeite (light); the homogeneous, clearly bound aggregates (light grey) are fluorapatite; minute white inclusions are Fe oxi-hydroxides. $5^{\text {th }}$ level of the Huber shaft. Width of photo $300 \mu \mathrm{m}$. Cameca SX100, BSE photograph by J. Sejkora and R. Škoda.

These two types of beraunite from Krásno (Table 5) clearly show a wider range of compositional variation than indicate data in the available literature. The general formula of beraunite can be written as $\mathrm{M}_{(\mathrm{a})} \mathrm{M}_{(\mathrm{b}) 5}\left(\mathrm{PO}_{4}\right)_{4}(\mathrm{OH})_{5}$ . $6 \mathrm{H}_{2} \mathrm{O}$. The results of structure analysis (Fanfani Zanazzi 1967; di Cossato et al. 1989; Moore - Kampf 1992) show $\mathrm{Fe}^{2+}$ (greenish black beraunite), $\mathrm{Fe}^{3+}$ (yellow, orange and red beraunite) and partly also $\mathrm{Mn}^{2+}$ (Mn-bearing beraunite) are present in the octahedral site $M_{(a)}$. The five octahedral sites $M_{(b)}$ (one M(2) site and two M(3) and M(4) sites, following the symbols of Moore - Kampf 1992), are occupied mainly by $\mathrm{Fe}^{3+}$ and small amounts of $\mathrm{Al}^{3+}$ and $\mathrm{Mn}^{2+}$ (or $\mathrm{Mn}^{3+}$ ?) in the known minerals related to beraunite. The preferential occupation of $M_{(b)}$-sites by Mn was described by di Cossato et al. (1989); however, Moore - Kampf (1992) proposed a disorder in Mn occupation of these sites using the same set of data. The chemical analyses of both types of beraunite from Krásno were recalculated on the basis of $(\mathrm{P}+\mathrm{As}+\mathrm{Si}+\mathrm{S})=4$ and interpreted using the assumption that all the following cations - Mn, $\mathrm{Zn}, \mathrm{Ca}$ etc. and $\mathrm{Fe}^{2+}-$ enter the $\mathrm{M}_{(\mathrm{a})}$ site (the content of $\mathrm{Fe}^{2+}$ was calculated to the ideal occupancy of 1.00 apfu in the site). The $M_{(b)}$-sites, not individually specified, are occupied by $\mathrm{Fe}^{3+}, \mathrm{Al}$ and $\mathrm{Ti}^{4+}$. The indicated water content was calculated from the theoretical content of $6.00 \mathrm{H}_{2} \mathrm{O}$ in beraunite and charge balance.

In $\mathrm{Zn}$ - and Al-rich beraunite from Krásno (Fig. 10) the $M_{(a)}$-site is dominated by $\mathrm{Fe}$ (probably $\mathrm{Fe}^{2+}$ ), corresponding to 0.46-0.69 apfu. Two spot-analyses show a slight predominance of $\mathrm{Zn}$ (the whole range is $0.24-0.48 \mathrm{apfu}$ ) and the total of other elements (Na, Mn, Ca etc.) does not exceed 0.1 apfu. The $M_{(b)}$-sites are dominated by $\mathrm{Fe}^{3+}$ (Fig. 11) ranging from 2.91 to $4.36 \mathrm{apfu}$. Also significant is the $\mathrm{Al}$ content $\left(0.53-1.79\right.$ apfu); the total for $M_{(b)}$-sites is 4.59-4.97 apfu. In the anion group (Fig. 12), P is strongly

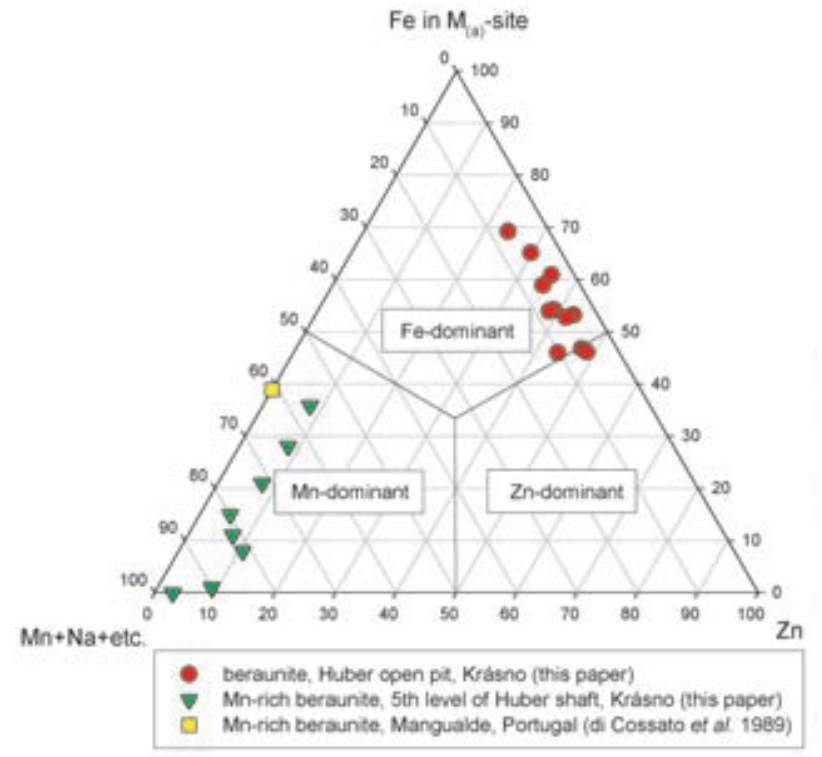

Fig. 10 Ternary plot of $M_{(a)}$-site occupancy of beraunites from Krásno and Mn-rich beraunite from Mangualde (di Cossato et al. 1989).

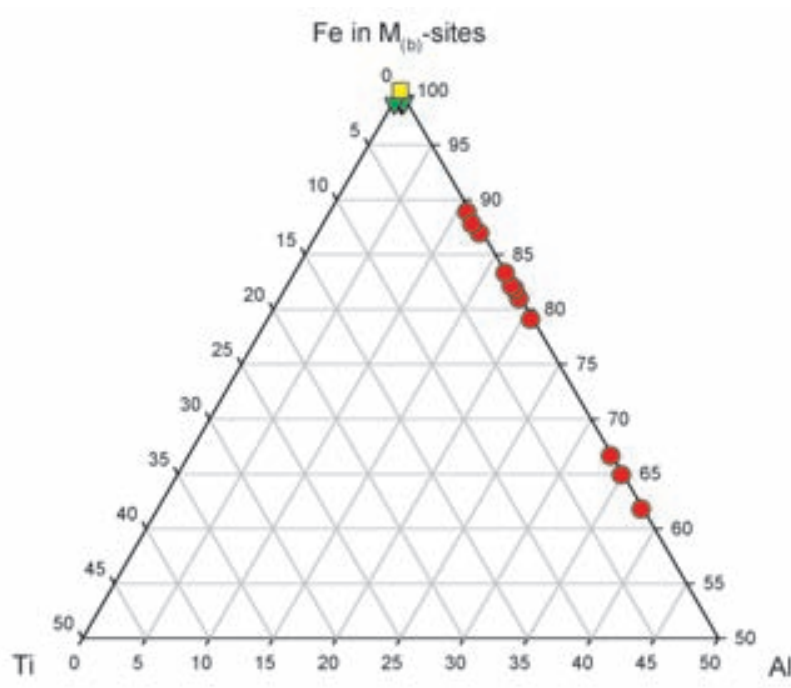

- beraunite, Huber open pit, Krásno (this paper)

Mn-rich beraunite, 5th level of Huber shaft, Krásno (this paper)

Mn-rich beraunite, Mangualde, Portugal (di Cossato et al. 1989)

Fig. 11 Part of ternary plot of $M_{(b)}$-sites occupancy of beraunites from Krásno and Mn-rich beraunite from Mangualde (di Cossato et al. 1989).

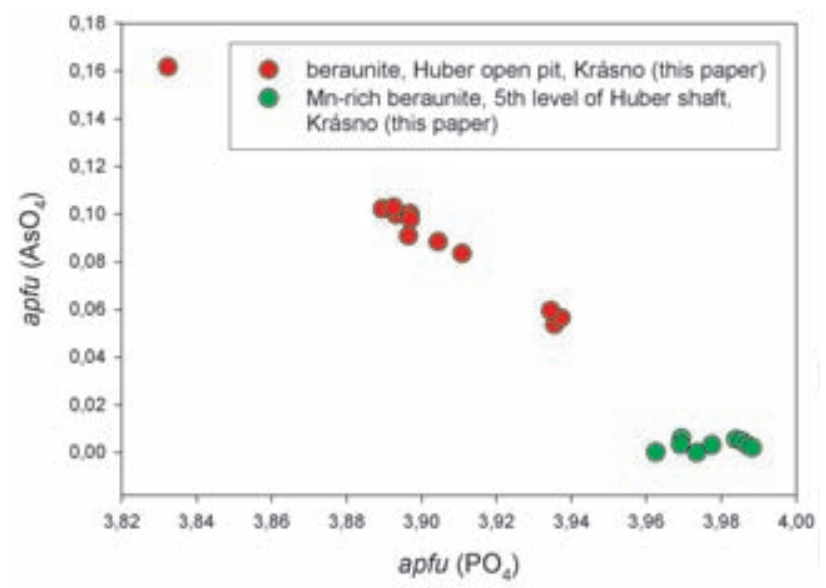

Fig. 12 A plot of $\left(\mathrm{PO}_{4}\right)$ vs. $\left(\mathrm{AsO}_{4}\right)(a p f u)$ in beraunites from Krásno. 
Table 5 Chemical composition of beraunites from Krásno (in wt. \%)

\begin{tabular}{|c|c|c|c|c|c|c|c|c|c|c|}
\hline & 1 & 2 & 3 & 4 & 5 & 6 & 7 & 8 & 9 & 10 \\
\hline $\mathrm{Na}_{2} \mathrm{O}$ & 0.09 & 0.10 & 0.14 & 0.16 & 0.13 & 0.07 & 0.48 & 0.35 & 0.55 & 0.78 \\
\hline $\mathrm{K}_{2} \mathrm{O}$ & 0.00 & 0.00 & 0.00 & 0.00 & 0.00 & 0.00 & 0.16 & 0.18 & 0.16 & 0.13 \\
\hline $\mathrm{CaO}$ & 0.05 & 0.00 & 0.10 & 0.16 & 0.00 & 0.03 & 0.38 & 0.41 & 0.44 & 0.30 \\
\hline $\mathrm{FeO}^{*}$ & 4.59 & 5.43 & 4.45 & 3.73 & 3.77 & 3.76 & 1.22 & 2.98 & 0.93 & 0.00 \\
\hline $\mathrm{BaO}$ & 0.04 & 0.07 & 0.02 & 0.00 & 0.08 & 0.00 & 0.05 & 0.00 & 0.09 & 0.13 \\
\hline $\mathrm{SrO}$ & 0.00 & 0.00 & 0.00 & 0.00 & 0.00 & 0.00 & 0.03 & 0.12 & 0.00 & 0.02 \\
\hline $\mathrm{MgO}$ & 0.02 & 0.01 & 0.01 & 0.04 & 0.00 & 0.03 & 0.05 & 0.00 & 0.10 & 0.08 \\
\hline $\mathrm{CuO}$ & 0.07 & 0.00 & 0.11 & 0.15 & 0.00 & 0.00 & 0.02 & 0.00 & 0.03 & 0.00 \\
\hline $\mathrm{MnO}$ & 0.11 & 0.14 & 0.06 & 0.04 & 0.14 & 0.16 & 4.44 & 3.01 & 4.28 & 5.60 \\
\hline $\mathrm{ZnO}$ & 3.51 & 2.80 & 3.59 & 4.02 & 4.37 & 4.46 & 0.69 & 0.75 & 0.69 & 0.29 \\
\hline $\mathrm{Al}_{2} \mathrm{O}_{3}$ & 5.88 & 5.17 & 10.49 & 9.87 & 3.03 & 3.35 & 0.18 & 0.18 & 0.23 & 0.03 \\
\hline $\mathrm{Fe}_{2} \mathrm{O}_{3} *$ & 34.57 & 34.86 & 26.75 & 28.73 & 39.16 & 39.42 & 44.00 & 42.09 & 44.51 & 45.11 \\
\hline $\mathrm{SiO}_{2}$ & 0.05 & 0.08 & 0.02 & 0.04 & 0.06 & 0.05 & 0.08 & 0.07 & 0.13 & 0.11 \\
\hline $\mathrm{TiO}_{2}$ & 0.09 & 0.07 & 0.08 & 0.08 & 0.14 & 0.22 & 0.21 & 0.19 & 0.07 & 0.50 \\
\hline $\mathrm{As}_{2} \mathrm{O}_{5}$ & 1.16 & 0.71 & 1.33 & 1.27 & 1.33 & 1.30 & 0.04 & 0.03 & 0.00 & 0.04 \\
\hline $\mathrm{P}_{2} \mathrm{O}_{5}$ & 31.56 & 32.35 & 31.79 & 31.22 & 31.16 & 31.27 & 32.73 & 32.94 & 32.09 & 31.91 \\
\hline $\mathrm{SO}_{3}$ & 0.00 & 0.00 & 0.00 & 0.00 & 0.00 & 0.00 & 0.07 & 0.00 & 0.17 & 0.10 \\
\hline $\mathrm{H}_{2} \mathrm{O}^{* *}$ & 16.88 & 16.62 & 16.67 & 16.98 & 16.91 & 17.22 & 17.00 & 16.38 & 17.07 & 17.39 \\
\hline total & 98.66 & 98.41 & 95.59 & 96.50 & 100.27 & 101.34 & 101.84 & 99.66 & 101.52 & 102.53 \\
\hline $\mathrm{Na}^{+}$ & 0.026 & 0.029 & 0.040 & 0.045 & 0.037 & 0.021 & 0.135 & 0.096 & $5 \quad 0.155$ & 0.222 \\
\hline $\mathrm{K}^{+}$ & 0.000 & 0.000 & 0.000 & 0.000 & 0.000 & 0.000 & 0.029 & 0.033 & 0.030 & 0.025 \\
\hline $\mathrm{Ca}^{2+}$ & 0.007 & 0.000 & 0.015 & 0.025 & 0.000 & 0.004 & 0.059 & 0.062 & 0.069 & 0.048 \\
\hline $\mathrm{Fe}^{2+}$ & 0.561 & 0.653 & 0.539 & 0.460 & 0.465 & 0.463 & 0.146 & 0.356 & 0.113 & 0.000 \\
\hline $\mathrm{Ba}^{2+}$ & 0.002 & 0.004 & 0.001 & 0.000 & 0.005 & 0.000 & 0.003 & 0.000 & 0.005 & 0.008 \\
\hline $\mathrm{Sr}^{2+}$ & 0.000 & 0.000 & 0.000 & 0.000 & 0.000 & 0.000 & 0.002 & 0.010 & 0.000 & 0.002 \\
\hline $\mathrm{Mg}^{2+}$ & 0.003 & 0.001 & 0.003 & 0.009 & 0.000 & 0.007 & 0.010 & 0.000 & 0.021 & 0.017 \\
\hline $\mathrm{Cu}^{2+}$ & 0.008 & 0.000 & 0.011 & 0.017 & 0.000 & 0.000 & 0.002 & 0.000 & 0.003 & 0.000 \\
\hline $\mathrm{Mn}^{2+}$ & 0.013 & 0.016 & 0.007 & 0.005 & 0.017 & 0.020 & 0.540 & 0.365 & 0.529 & 0.697 \\
\hline $\mathrm{Zn}^{2+}$ & 0.379 & 0.297 & 0.384 & 0.438 & 0.476 & 0.484 & 0.073 & 0.079 & 0.074 & 0.032 \\
\hline$M_{(a)}$ site & 1.000 & 1.000 & 1.000 & 1.000 & 1.000 & 1.000 & 1.000 & 1.000 & 1.000 & 1.050 \\
\hline $\mathrm{Al}^{3+}$ & 1.013 & 0.876 & 1.789 & 1.715 & 0.526 & 0.581 & 0.030 & 0.030 & 0.039 & 0.005 \\
\hline $\mathrm{Fe}^{3+}$ & 3.800 & 3.769 & 2.914 & 3.187 & 4.344 & 4.362 & 4.753 & 4.528 & 4.885 & 4.987 \\
\hline $\mathrm{Ti}^{4+}$ & 0.010 & 0.008 & 0.008 & 0.009 & 0.016 & 0.024 & 0.022 & 0.021 & 0.007 & 0.055 \\
\hline$M_{(b)}$ site & 4.824 & 4.653 & 4.712 & 4.911 & 4.887 & 4.968 & 4.806 & 4.579 & 4.931 & 5.047 \\
\hline $\mathrm{As}^{5+}$ & 0.088 & 0.054 & 0.100 & 0.098 & 0.102 & 0.100 & 0.003 & 0.002 & 0.000 & 0.003 \\
\hline $\mathrm{P}^{5+}$ & 3.904 & 3.936 & 3.897 & 3.897 & 3.890 & 3.893 & 3.978 & 3.988 & 3.963 & 3.969 \\
\hline$S^{6+}$ & 0.000 & 0.000 & 0.000 & 0.000 & 0.000 & 0.000 & 0.008 & 0.000 & 0.019 & 0.011 \\
\hline $\mathrm{Si}^{4+}$ & 0.007 & 0.011 & 0.003 & 0.005 & 0.008 & 0.007 & 0.012 & 0.010 & 0.019 & 0.017 \\
\hline $\mathrm{T}$ sites & 4.000 & 4.000 & 4.000 & 4.000 & 4.000 & 4.000 & 4.000 & 4.000 & 4.000 & 4.000 \\
\hline $\mathrm{OH}$ & 4.448 & 3.927 & 4.103 & 4.692 & 4.630 & 4.899 & 4.275 & 3.620 & 4.616 & 5.042 \\
\hline $\mathrm{H}_{2} \mathrm{O}$ & 6.003 & 6.002 & 6.000 & 6.003 & 6.001 & 5.998 & 6.002 & 6.002 & 5.997 & 6.000 \\
\hline
\end{tabular}

$\mathrm{Zn}$ - and Al-rich beraunite: 1 - mean of 12 spot analyses; 2-6 - representative spot analyses;

Mn-rich beraunite: 7 - mean of 8 spot analyses; 8-10 - representative spot analyses.

Empirical formulas were calculated on the basis of $(\mathrm{P}+\mathrm{As}+\mathrm{Si}+\mathrm{S})=4.00$;

* - calculation of $\mathrm{Fe}_{\text {tot }}$ to $\mathrm{Fe}^{2+}$ and $\mathrm{Fe}^{3+}$ is based on the assumption that $\mathrm{Fe}^{2+}$ (together with $\mathrm{M}^{1+}$ and

$\mathrm{M}^{2+}$ elements) completely fills the $\mathrm{M}_{(\mathrm{a})}$ position and only the surplus Fe (above $1 p f u$ ) enters the sites

$\mathrm{M}(\mathrm{b})$ as $\mathrm{Fe}^{3+}$;

** $-\mathrm{H}_{2} \mathrm{O}$ content is calculated from the general formula $\left(\mathrm{H}_{2} \mathrm{O}=6.00\right)$ and charge balance.

dominating, As is low (0.05-0.16 apfu) and Si is below $0.01 \mathrm{apfu}$. The average empirical formula (12 spot analyses) of the $\mathrm{Zn}$ - and Al-rich beraunite from Krásno, based on $4(\mathrm{P}+\mathrm{As}+\mathrm{S}+\mathrm{Si})$ and the above noted assumptions, is $\left(\mathrm{Fe}_{0.56} \mathrm{Zn}_{0.38} \mathrm{Na}_{0.03} \mathrm{Mn}_{0.01} \mathrm{Ca}_{0.01} \mathrm{Cu}_{0.01}\right)_{\Sigma 1.00}\left(\mathrm{Fe}_{3.80} \mathrm{Al}_{1.01} \mathrm{Ti}_{0.01}\right)_{\Sigma 4.82}$ $\left[\left(\mathrm{PO}_{4}\right)_{3.90}\left(\mathrm{AsO}_{4}\right)_{0.09}\left(\mathrm{SiO}_{4}\right)_{0.01}\right]_{\Sigma 4.00}(\mathrm{OH})_{4.45} \cdot 6.00 \mathrm{H}_{2} \mathrm{O}$.

The $M_{(a)}$-site in Mn-rich beraunite from Krásno (Fig. 10) is dominated by Mn (0.36-0.70 apfu). In addition, the site contains significant $\mathrm{Fe}^{2+}$ (max. 0.36 apfu) and increased $\mathrm{Na}$ in the range of 0.09 to 0.22 apfu. The group of $M_{(b)}$-sites (Fig. 11) is filled dominantly by $\mathrm{Fe}^{3+}$ (4.53-4.99 apfu), while Al and Ti contents are minor (max. $0.05 a p f u)$. The tetrahedral sites are almost exclusively occupied by P (Fig. 12), As, Si and $\mathrm{S}$ contents reach max. 0.01 apfu. The average empirical formula ( 8 spot analyses) for Mn-rich beraunite from Krásno can be presented on the basis of $4(\mathrm{P}+\mathrm{As}+\mathrm{S}+\mathrm{Si})$ and the above assumptions as $\left(\mathrm{Mn}_{0.54} \mathrm{Fe}_{0.14} \mathrm{Na}_{0.13} \mathrm{Zn}_{0.07} \mathrm{Ca}_{0.06} \mathrm{~K}_{0.03} \mathrm{Mg}_{0.01}\right)_{\Sigma 0.98}\left(\mathrm{Fe}_{4.75} \mathrm{Al}_{0.03}\right.$ $\left.\mathrm{Ti}_{0.02}\right)_{\Sigma 4.80}\left[\left(\mathrm{PO}_{4}\right)_{3.98}\left(\mathrm{SiO}_{4}\right)_{0.01}\left(\mathrm{SO}_{4}\right)_{0.01}\right]_{\Sigma 4.00}(\mathrm{OH})_{4.27} \cdot 6.00 \mathrm{H}_{2} \mathrm{O}$. The complicated composition of Mn-rich beraunite from Krásno can be demonstrated by comparison with the empirical formula (calculated on the same basis) of Mnrich beraunite from Mangualde (di Cossato et al. 1989) $\left(\mathrm{Mn}_{0.54} \mathrm{Fe}_{0.38} \mathrm{Na}_{0.04} \mathrm{Ca}_{0.03} \mathrm{Li}_{0.01}\right)_{\Sigma 1.00} \mathrm{Fe}_{5.18}\left(\mathrm{PO}_{4}\right)_{4.00}(\mathrm{OH})_{5.54}$. $4.92 \mathrm{H}_{2} \mathrm{O}$. 


\section{Cacoxenite $\mathrm{Fe}^{3+}{ }_{24} \mathrm{Al}\left(\mathrm{PO}_{4}\right)_{17} \mathrm{O}_{6}(\mathrm{OH})_{12} \cdot 75 \mathrm{H}_{2} \mathrm{O}$}

It has been found as tufts or radiating aggregates (Fig. 13), up to $5 \mathrm{~mm}$ in diameter, of typical golden yellow colour in samples from the Huber open pit. A similar material occurs in cavities in phosphate accumulations at the $5^{\text {th }}$ level of the Huber mine. At this place, cacoxenite belongs to the youngest minerals. The mineral was identified by $\mathrm{X}$-ray powder diffraction.

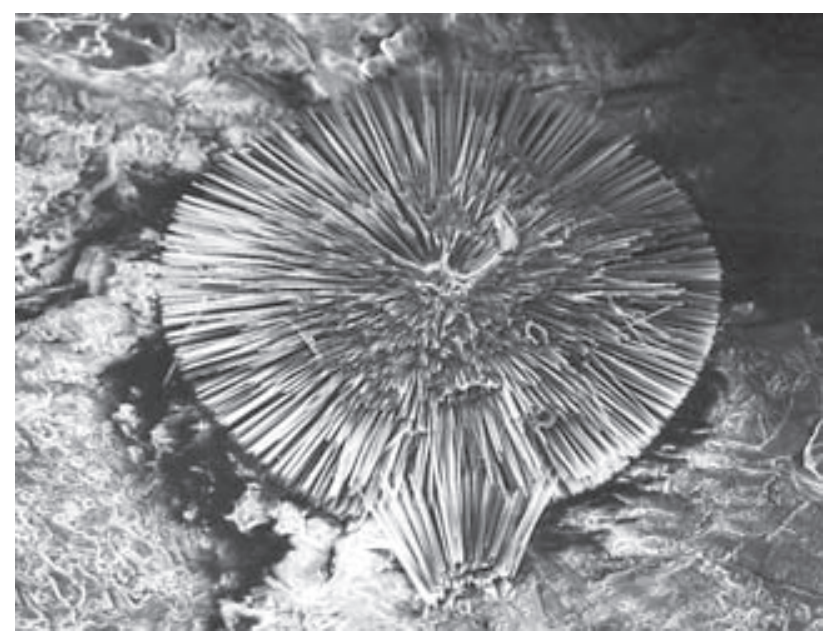

Fig. 13 A radiating fibrous aggregate of cacoxenite, Huber open pit, Krásno. Width of photo $500 \mu \mathrm{m}$. SEM photograph by Z. Mach.

\section{Chalcosiderite $\mathrm{CuFe}_{6}^{3+}\left[\mathrm{PO}_{4}(\mathrm{OH})_{2}\right]_{4} \cdot 4 \mathrm{H}_{2} \mathrm{O}$ Turquoise $\mathrm{CuAl}_{6}\left[\mathrm{PO}_{4}(\mathrm{OH})_{2}\right]_{4} \cdot 4 \mathrm{H}_{2} \mathrm{O}$ (turqouise group)}

Chalcosiderite has been described by Mach (1979) and later by Korbel (1991) at the Huber open pit as rare green rosette-shaped agreggates, up to $1.5 \mathrm{~mm}$. It occurs in cavities of quartz gangue with wolframite.

During the present study, members of the turquoise group have been found as relatively widespread minerals at various places of the Huber open pit in phosphate accumulations (or in their proximity) showing a strong supergene alteration. The phosphate accumulations, from $\mathrm{mm}$ up to dm in size and located in massive white quartz, consist of fluorapatite, locally with abundant compact isokite and triplite relics. Minor weathered cavities in these accumulations are coated by minute crystalline aggregates of the turquoise group minerals. Macroscopically indistinguishable members of this group are accompanied by fluorapatite of the youngest generation, leucophosphite, pharmacosiderite, rare kolbeckite, whitmoreite and unnamed mineral phases UNK1, UNK3, UNK6, UNK7, $U N K 8$ and $U N K 10$ (Sejkora et al. 2006). Minerals of the turquoise group form crystals (Fig. 14) grouped to irregular spheroidal aggregates deposited individually or grouped in small crystalline coatings (Fig. 15) as the youngest minerals in the phosphate association. Individual aggregates are usually less than $1 \mathrm{~mm}$ in size (fre-

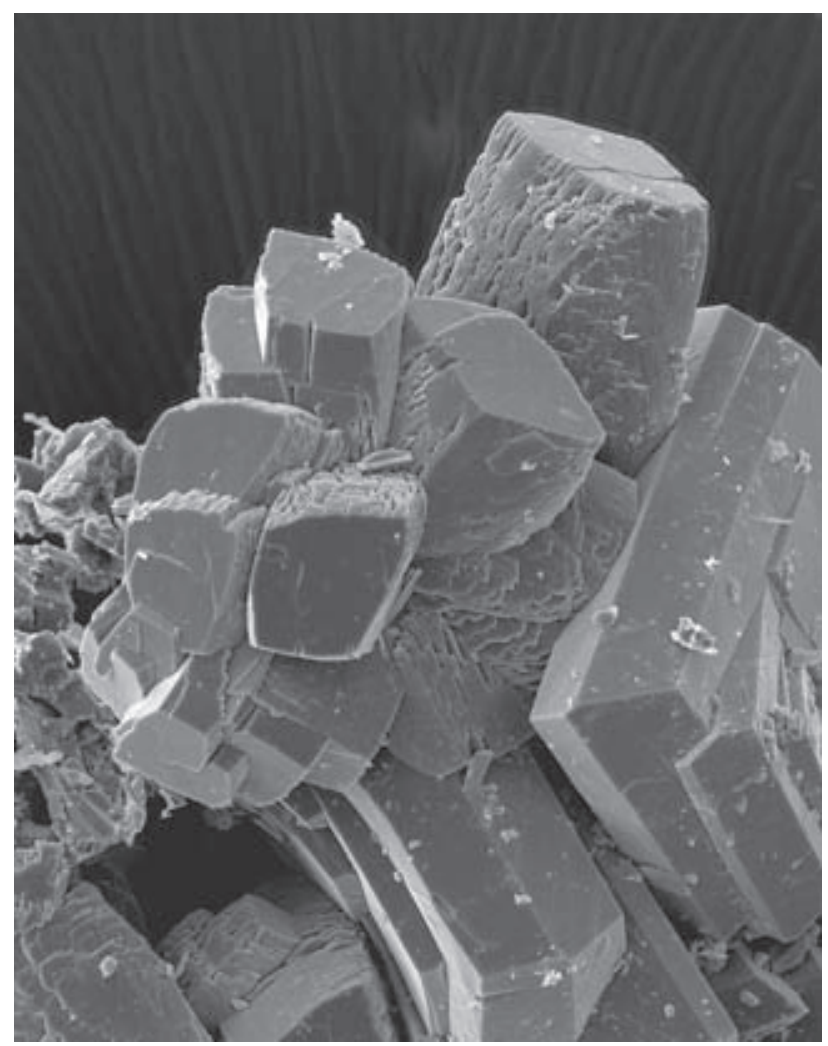

Fig. 14 Crystals of chalcosiderite-turqouise series minerals on tabular crystals of leucophosphite, Huber open pit, Krásno. Width of photo $130 \mu \mathrm{m}$. SEM photograph by J. Sejkora and J. Plášil.

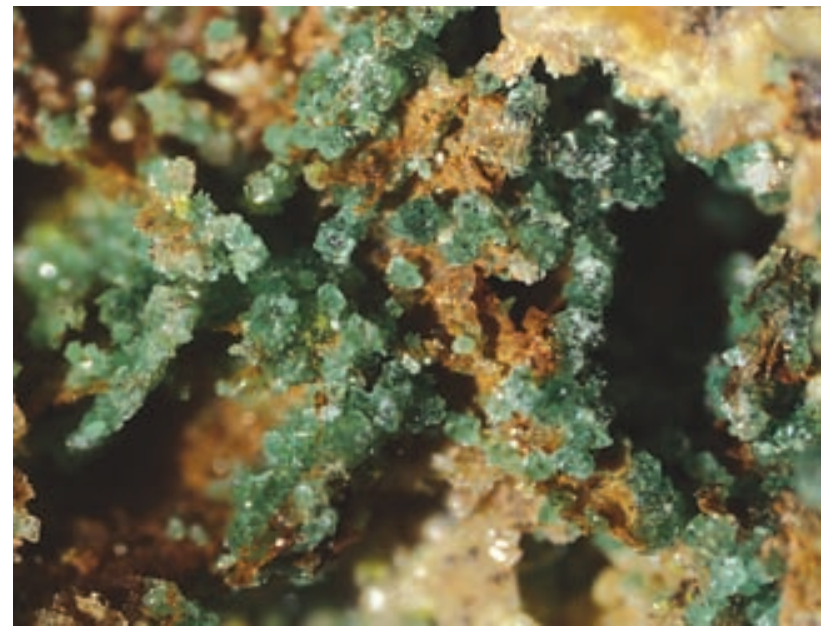

Fig. 15 Semi-spheroidal aggregates of members of the series chalcosiderite - turquoise; Huber open pit, Krásno. Width of photo $4 \mathrm{~mm}$. Microphotography Nicon SMZ1500 by J.\&E. Sejkora.

quently $0.1-0.3 \mathrm{~mm}$ ), exceptionally up to $1.8 \mathrm{~mm}$. The colour is usually deep bright green with various shades, lustre is vitreous, only small fragments are partly transparent. The individual aggregates always show compositional zoning (Fig. 16). Zones with predominance of Fe (chalcosiderite) or Al (turquoise) are usually present in a single aggregate.

At present, chalcosiderite occurrence has been confirmed at the $5^{\text {th }}$ level of the Huber shaft as green spheres 


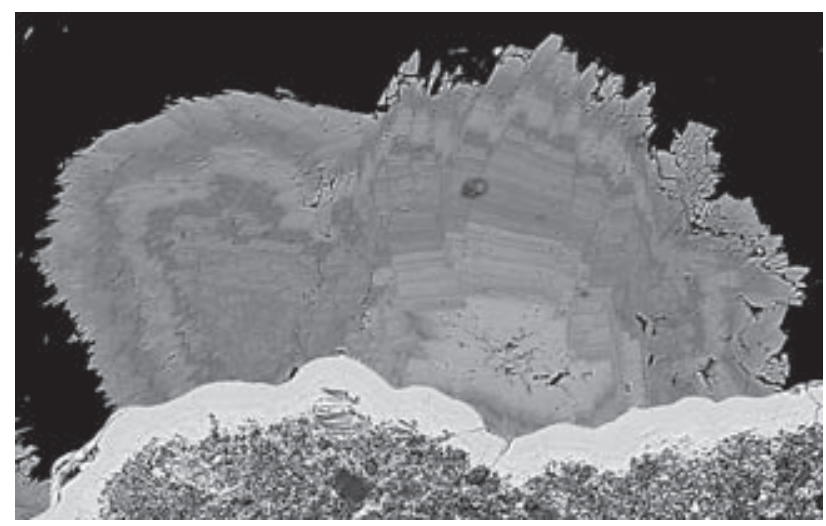

Fig. 16 Complicated zoning in semi-spheroidal aggregates of chalcosiderite (light zones) - turquoise (dark zones) growing on limonite crust (light), Huber open pit, Krásno. Width of photo $300 \mu \mathrm{m}$. BSE photograph, Cameca SX100, by J. Sejkora and R. Škoda.

to $0.5 \mathrm{~mm}$ in diameter, associated with crystalline and porous aggregates of isokite. Rare aggregates of chalcopyrite and chalcocite, intergrown in the primary phosphates (triplite), served as the source of copper.

All recorded occurrences of the turquoise group minerals have been verified by X-ray powder diffraction. The present study shows prominent chemical zoning of samples from the Huber open pit. The analyses document the presence of members ranging through nearly the whole isomorphous series chalcosiderite - turquoise (Fig. 17). From the minimal contents of $\mathrm{Fe}$ in chalcosiderite at c. 0.88 apfu to the minimal contents of $\mathrm{Al}$ in turquoise at c. 0.43 apfu. The occupancy of the $\mathrm{M}^{2+}$ site attains 1.0 to 1.4 apfu $\mathrm{Cu}$. This indicates that the studied minerals do not exhibit heterovalent isomorphism of planerite type $\mathrm{Cu}-\square \rightarrow\left(\mathrm{PO}_{4}\right)-\left(\mathrm{PO}_{3} \mathrm{OH}\right)$ (Foord Taggart 1998). The anion group contains regular amounts of As in the range of 0.03-0.11 (turqouise) and up to 0.58 apfu (chalcosiderite) (Fig. 18). The first record of elevated Ti content up to 0.12 apfu and the presence of fluorine in rare examples

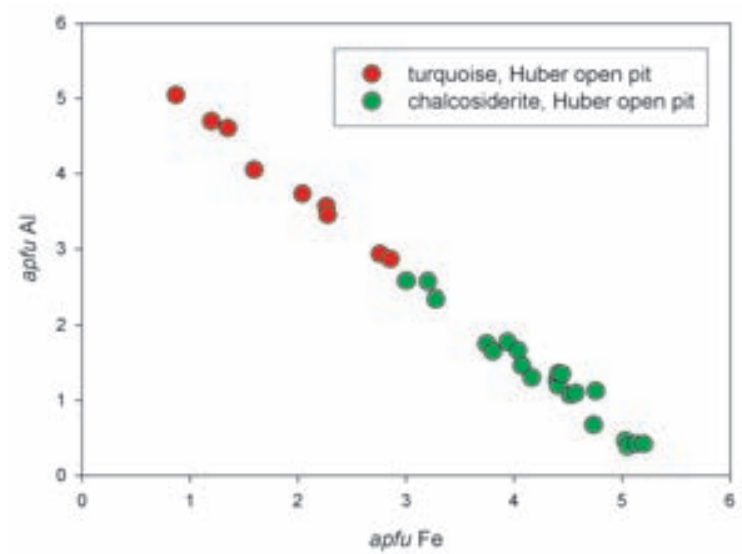

Fig. 17 A plot of Fe apfu vs. Al apfu in minerals of the turquoise group. Huber open pit, Krásno.

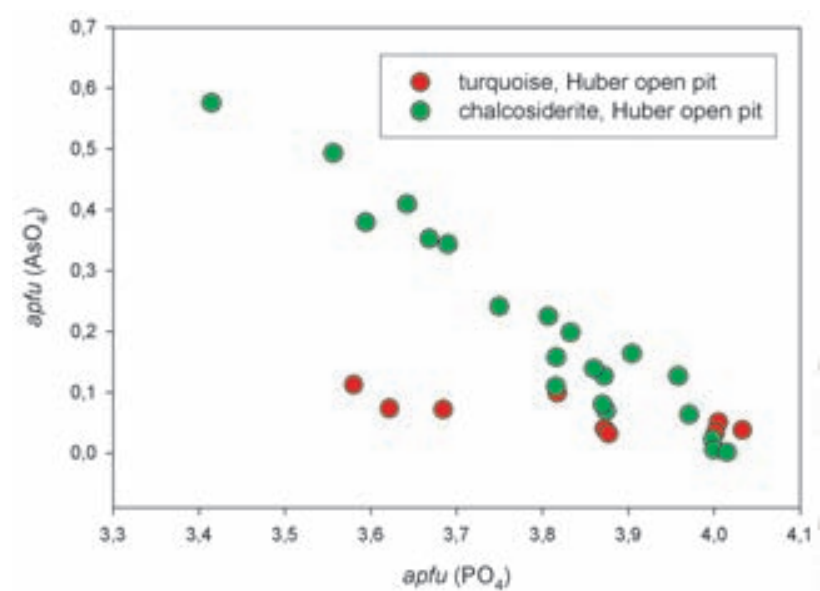

Fig. 18 A plot of $\left(\mathrm{PO}_{4}\right)$ apfu vs. $\left(\mathrm{AsO}_{4}\right)$ apfu in the turquoise group minerals. Huber open pit, Krásno.

up to 0.20 apfu in minerals of the turquoise group were given in this study. The representative compositions of members of this group (Table 6), with empirical formulas, document the wide variation. The high totals of some analyses are probably due to sample dehydration by electron beam in vacuum.

Table 6 Chemical composition of members of the isomorphous series chalcosiderite - turquoise (in wt. \%)

\begin{tabular}{|l|rrrrrrrc|}
\hline & 1. & \multicolumn{1}{c}{2.} & \multicolumn{1}{c}{3.} & \multicolumn{1}{c}{4.} & \multicolumn{1}{c}{5.} & \multicolumn{1}{c}{6.} & \multicolumn{1}{c}{7.} & \multicolumn{1}{c|}{8.} \\
\hline $\mathrm{CuO}$ & 9.78 & 10.12 & 11.85 & 10.53 & 9.45 & 8.94 & 9.97 & 8.06 \\
$\mathrm{PbO}$ & & 0.14 & 0.25 & 0.25 & 0.07 & & 0.25 & \\
$\mathrm{ZnO}$ & & 0.23 & 0.12 & 0.06 & 0.43 & 0.41 & 0.17 & \\
$\mathrm{CaO}$ & & 0.06 & 0.02 & 0.06 & 0.09 & 0.03 & 0.06 & \\
$\mathrm{BaO}$ & & 0.21 & & & & 0.21 & & \\
$\mathrm{SrO}$ & & 0.09 & & & & & 0.02 & \\
$\mathrm{Al}_{2} \mathrm{O}_{3}$ & 37.60 & 33.00 & 22.30 & 16.00 & 13.87 & 7.30 & 2.15 & \\
$\mathrm{Fe}_{2} \mathrm{O}_{3}$ & & 8.95 & 19.17 & 25.08 & 27.14 & 37.19 & 41.47 & 48.56 \\
$\mathrm{TiO}_{2}$ & & 0.31 & & & & 0.04 & & \\
$\mathrm{P}_{2} \mathrm{O}_{5}$ & 34.90 & 33.51 & 32.22 & 31.14 & 27.56 & 27.57 & 25.56 & 28.77 \\
$\mathrm{As}_{2} \mathrm{O}_{5}$ & & 1.06 & 0.54 & 0.43 & 4.29 & 4.16 & 4.37 & \\
$\mathrm{SO}_{3}$ & & & & & 0.09 & 0.12 & 0.85 & \\
$\mathrm{~F}$ & & 0.49 & 0.04 & & & & & \\
$-\mathrm{O}=\mathrm{F}$ & & 0.21 & 0.02 & & & & & \\
$\mathrm{H}_{2} \mathrm{O}^{*}$ & 17.72 & 17.80 & 16.50 & 15.38 & 15.12 & 14.52 & 13.88 & 14.61 \\
total & 100.00 & 105.77 & 102.98 & 98.94 & 98.10 & 100.51 & 99.00 & 100.00 \\
\hline
\end{tabular}

* $\mathrm{H}_{2} \mathrm{O}$ content calculated from the ideal formula $\mathrm{CuM}_{6}\left[\mathrm{PO}_{4}(\mathrm{OH})_{2}\right]_{4} \cdot 4 \mathrm{H}_{2} \mathrm{O}(\mathrm{M}=\mathrm{Fe}, \mathrm{Al})$ and charge balance; empirical formulas were calculated on the basis of $28(\mathrm{O}, \mathrm{OH})$.

1. theoretical composition of turquoise $\mathrm{CuAl}_{6}\left[\mathrm{PO}_{4}(\mathrm{OH})_{2}\right]_{4} \cdot 4 \mathrm{H}_{2} \mathrm{O}$

2. turquoise with the highest $\mathrm{Al}$ content analyzed, corresponding to empirical formula: $\left(\mathrm{Cu}_{1.00} \mathrm{Zn}_{0.02} \mathrm{Ba}_{0.01} \mathrm{Sr}_{0.01}\right)_{\Sigma 1.04}\left(\mathrm{Al}_{5.10} \mathrm{Fe}_{0.88} \mathrm{Ti}_{0.03}\right)_{\Sigma 6.01}\left[\left(\mathrm{PO}_{4}\right)_{3.72}\left(\mathrm{AsO}_{4}\right)_{0.07} \mathrm{~F}_{0.20}\right]_{\Sigma 3.99}(\mathrm{OH})_{8.47}$. $4.00 \mathrm{H}_{2} \mathrm{O}$.

3. turquoise of an intermediate composition, corresponding to empirical formula: $\left(\mathrm{Cu}_{1.28} \mathrm{Zn}_{0.01}\right)_{\Sigma 1.29}\left(\mathrm{Al}_{3.76} \mathrm{Fe}_{2.06}\right)_{\Sigma 5.82}\left[\left(\mathrm{PO}_{4}\right)_{3.99}\left(\mathrm{AsO}_{4}\right)_{0.04} \mathrm{~F}_{0.02}\right]_{\Sigma 4.05}(\mathrm{OH})_{8.21} \cdot 4.00 \mathrm{H}_{2} \mathrm{O}$.

4. turquoise with composition near the turquoise/chalcosiderite limit, corresponding to empirical formula:

$\left(\mathrm{Cu}_{1.22} \mathrm{Ca}_{0.01} \mathrm{~Pb}_{0.01}\right)_{\Sigma 1.24}\left(\mathrm{Al}_{2.90} \mathrm{Fe}_{2.90}\right)_{\Sigma 5.80}\left[\left(\mathrm{PO}_{4}\right)_{4.06}\left(\mathrm{AsO}_{4}\right)_{0.03}\right]_{\Sigma 4.09}(\mathrm{OH})_{7.62} \cdot 4.00 \mathrm{H}_{2} \mathrm{O}$.

5. chalcosiderite with composition near the limit chalcosiderite/turquoise, corresponding to empirical formula:

$\left(\mathrm{Cu}_{1.13} \mathrm{Zn}_{0.05} \mathrm{Ca}_{0.02}\right)_{\Sigma 1.20}\left(\mathrm{Fe}_{3.24} \mathrm{Al}_{2.60}\right)_{\Sigma 5.84}\left[\left(\mathrm{PO}_{4}\right)_{3.70}\left(\mathrm{AsO}_{4}\right)_{0.36}\right]_{\Sigma 4.06}(\mathrm{OH})_{7.71} \cdot 4.00 \mathrm{H}_{2} \mathrm{O}$

6. chalkosiderite of an intermediate composition, corresponding to empirical formula: $\left(\mathrm{Cu}_{1.08} \mathrm{Zn}_{0.05} \mathrm{Ba}_{0.01}\right)_{\Sigma 1.14}\left(\mathrm{Fe}_{4.48} \mathrm{Al}_{1.38}\right)_{\Sigma 5.86}\left[\left(\mathrm{PO}_{4}\right)_{3.74}\left(\mathrm{AsO}_{4}\right)_{0.35}\right]_{\Sigma 4.09}(\mathrm{OH})_{7.59} \cdot 4.00 \mathrm{H}_{2} \mathrm{O}$.

7. chalcosiderite with the highest analyzed content, corresponding to empirical formula:

$\left(\mathrm{Cu}_{1.27} \mathrm{Zn}_{0.02} \mathrm{~Pb}_{0.01}\right)_{\Sigma 1.30}\left(\mathrm{Fe}_{5.29} \mathrm{Al}_{0.43}\right)_{\Sigma 5.72}\left[\left(\mathrm{PO}_{4}\right)_{3.64}\left(\mathrm{AsO}_{4}\right)_{0.39}\left(\mathrm{SO}_{4}\right)_{0.10}\right]_{\Sigma 4.13}(\mathrm{OH})_{7.44} \cdot 4.00 \mathrm{H}_{2} \mathrm{O}$. 8. theoretical composition of chalcosiderite $\mathrm{CuFe}_{6}\left[\mathrm{PO}_{4}(\mathrm{OH})_{2}\right]_{4} \cdot 4 \mathrm{H}_{2} \mathrm{O}$ 


\section{Crandallite $\mathrm{CaAl}_{3}\left(\mathrm{PO}_{4}\right)\left(\mathrm{PO}_{3} \mathrm{OH}\right)(\mathrm{OH})_{6}$ Goyazite $\mathrm{SrAl}_{3}\left(\mathrm{PO}_{4}\right)\left(\mathrm{PO}_{3} \mathrm{OH}\right)(\mathrm{OH})_{6}$ Waylandite $\mathrm{BiAl}_{3}\left(\mathrm{PO}_{4}\right)_{2}(\mathrm{OH})_{6}$ (crandallite group)}

\section{Crandallite $\mathrm{CaAl}_{3}\left(\mathrm{PO}_{4}\right)\left(\mathrm{PO}_{3} \mathrm{OH}\right)(\mathrm{OH})_{6}$}

Mrázek (1981) published the first description of crandallite from the Huber open pit as orange semi-spheroidal aggregates to $1 \mathrm{~mm}$. It includes X-ray data, a qualitative chemical analysis and IR spectrum, confirming the presence of the group $\left(\mathrm{PO}_{3} \mathrm{OH}\right)^{2-}$ in crandallite. Bi-rich crandallite has been described by Novák et al. (2001) from greisen dump material deposited behind the former Stannum mine. It forms cryptocrystalline, in part porous, light yellow white or yellow brown aggregates among quartz crystals and earthy crusts, up to $3 \mathrm{~mm}$ thick, on cassiterite and quartz. It represents a mixture with unnamed phase UNK11 (Sejkora et al. 2006). Novák et al. (2001) presented its unit-cell parameters (Table 7) and chemical analysis, which, based on $2(\mathrm{P}+\mathrm{As}+\mathrm{S}+\mathrm{Si})$, gives the empirical formula: $\left(\mathrm{Ca}_{0.50} \mathrm{Sr}_{0.34} \mathrm{Bi}_{0.17}\right)_{\Sigma 1.01}\left(\mathrm{Al}_{2.66} \mathrm{Fe}_{0.25} \mathrm{Cu}_{0.02}\right)_{\Sigma 2.93}$ $\left[\left(\mathrm{PO}_{4}\right)_{1.13}\left(\mathrm{PO}_{3} \mathrm{OH}\right)_{0.68}\left(\mathrm{AsO}_{4}\right)_{0.13}\left(\mathrm{SO}_{4}\right)_{0.05}\right]_{\Sigma 1.99}(\mathrm{OH})_{6.00}$.

We have studied samples collected at different places of the Huber open pit. The mineral occurs in minute, less than $1 \mathrm{~mm}$, irregular semi-spheroidal aggregates (Fig. 19) composed of very thin tabular crystals up to $100 \mu \mathrm{m}$ long (Fig. 20). The mineral is associated with turquoise-group minerals (Fig. 21), young fluorapatite and fluorite in small cavities of coarse-grained quartz

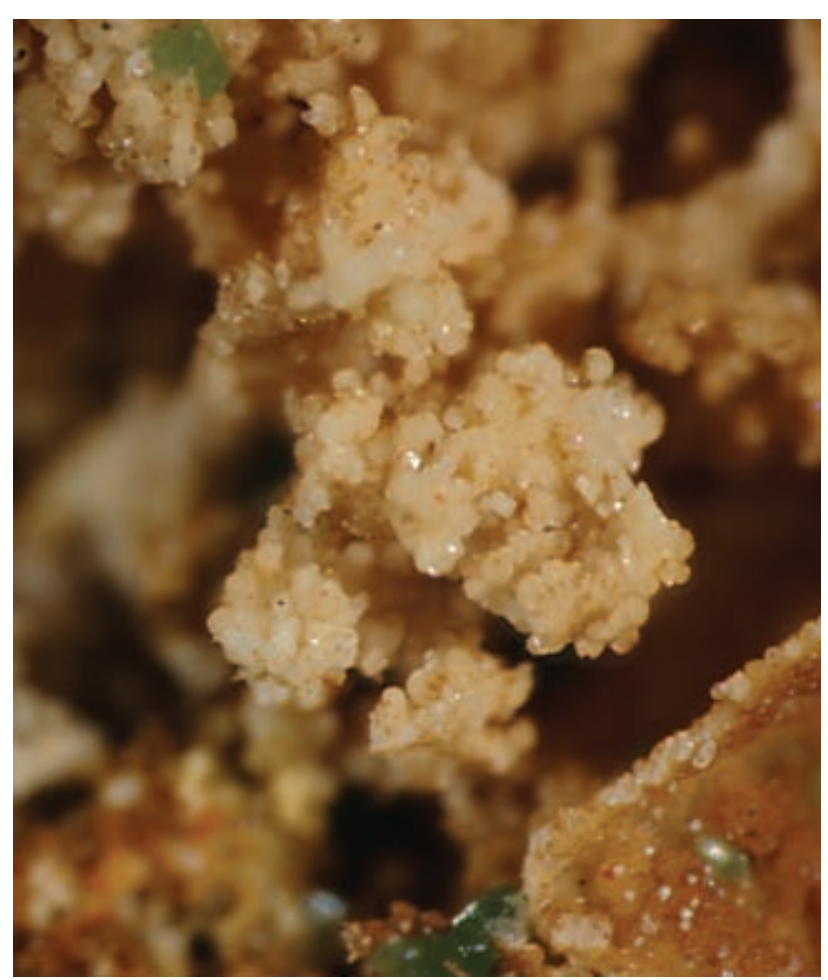

Fig. 19 Irregular semi-spheroidal crandallite aggregates to $1 \mathrm{~mm}$, composed of minute tabular crystals. Huber open pit, Krásno. Width of photo $2.5 \mathrm{~mm}$. Nicon SMZ1500 microphotography by J. \& E. Sejkora.

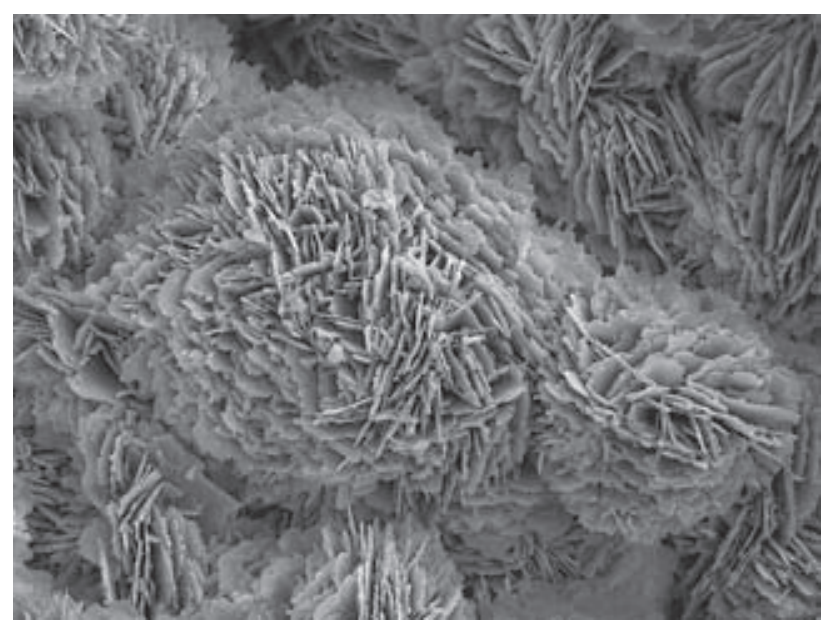

Fig. 20 Thin tabular crandallite crystals composing semi-spheroidal aggregates. Huber open pit, Krásno. Width of photo $130 \mu \mathrm{m}$. SEM photograph by J. Sejkora.

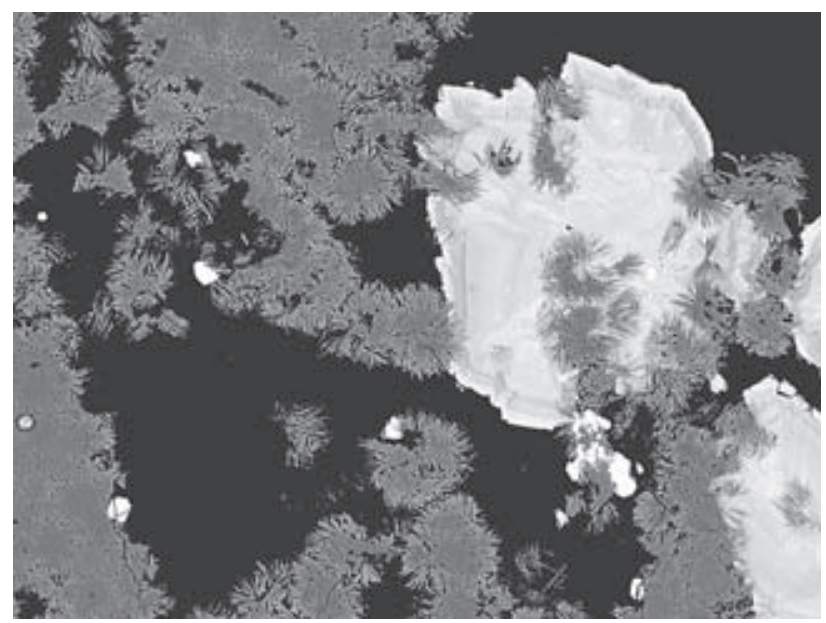

Fig. 21 Semi-spheroidal crandallite aggregates composed of minute tabular crystals (dark) in association with zoned aggregates of the turquoise-group minerals (light). Width of photo $400 \mu \mathrm{m}$. Huber open pit, Krásno. BSE photograph, Cameca SX100 by J. Sejkora and R. Škoda.

gangue. The crandallite aggregates are whitish or light pink to light orange with vitreous lustre and transparent only in thin splinters. Crandallite has also been identified as a component in strongly zoned goyazite and crandallite aggregates (see goayzite for detailed description).

$\mathrm{X}$-ray powder data as well as refined unit-cell parameters (Table 7) compare well with data for minerals of the crandallite - goyazite series. Comparison of the refined unit-cell parameters, as well as X-ray powder patterns, shows that distinguishing these two mineral species solely by X-ray methods is problematic, owing to wide isomorphism.

The chemical composition of the crandallite-type minerals is characterized by wide isomorphous substitution in all structural sites of the general formula $\mathrm{AB}_{3}\left(\mathrm{TO}_{4}\right)\left(\mathrm{TO}_{3} \mathrm{OH}\right)(\mathrm{OH}, \mathrm{F})_{6}$. Possible substitutions by individual elements in large ${ }^{[12]} A-$, medium ${ }^{[6]} B$ - and small ${ }^{[4]} T$-fold positions are shown in Fig. 22 . The chemical analyses of crandallite-type minerals from Krásno (Table 8) were recalculated on the basis of $(\mathrm{P}+\mathrm{As}+\mathrm{S}+\mathrm{Si})=2$. 


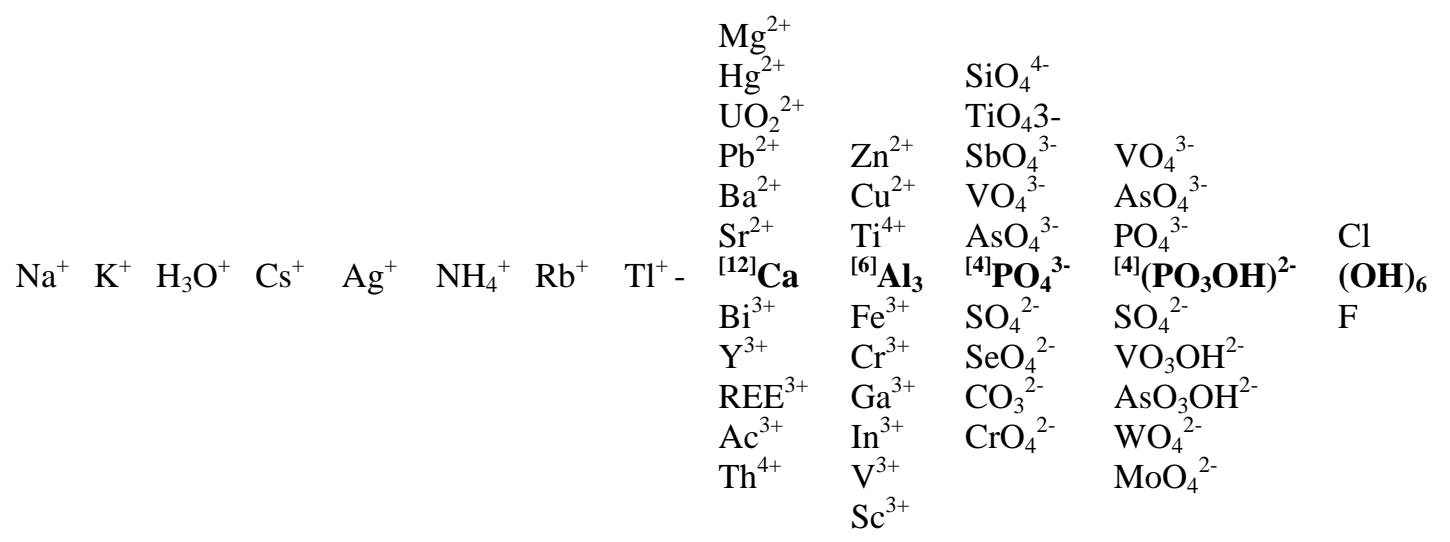

Fig. 22 Possible substitutions in crandallite-type minerals (alunite, beudantite and crandallite groups), modified following Schwab et al. (2004), with the use of data by Scott (1987), Novák et al. (1994), Pe-Piper - Dolansky (2005).

Calcium (0.52-0.85 apfu) is the dominant element in $A$-site of crandallite (Fig. 23) and significant quantities of $\mathrm{Sr}(0.07-0.43 \mathrm{apfu})$ are also present. The contents of other elements, in particular $\mathrm{Ba}$ and $\mathrm{K}$, are up to 0.04 apfu. Relative to the data published by Novák et al. (2001), our samples contained only negligible Bi (below 0.01 apfu). The $B$-site in crandallite (Fig. 24) is filled dominantly by Al (2.80-2.91 apfu), whereas Fe contents

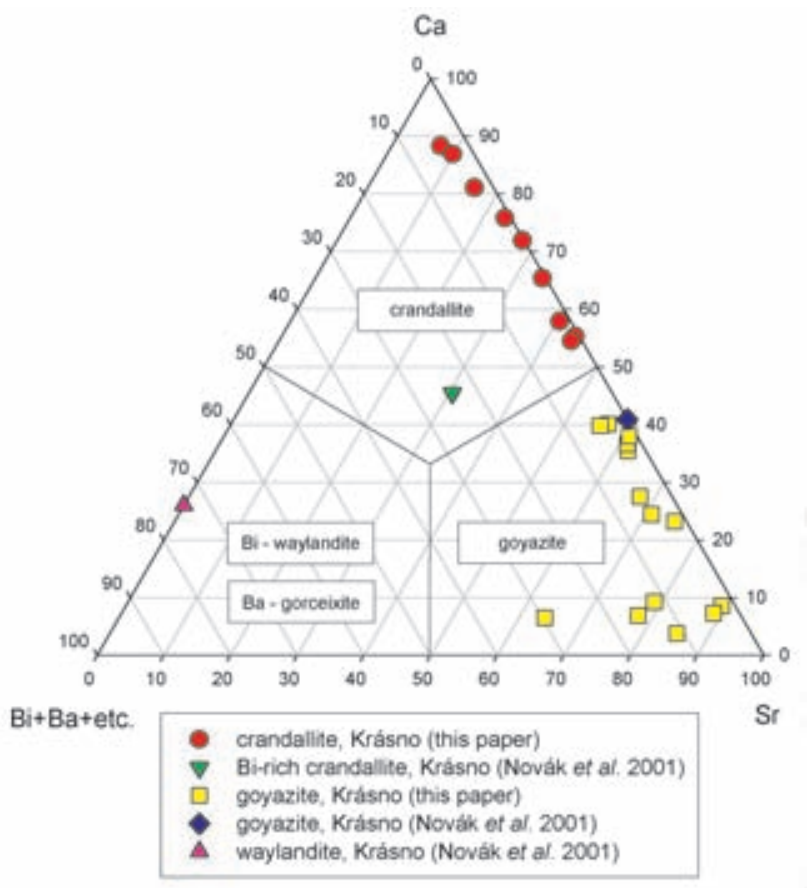

Fig. 23 Ternary plot of $A$-site occupancy (atomic ratio) in crandallitetype minerals from the Huber open pit, Krásno. reach only exceptionally $0.02 \mathrm{apfu}$, in difference to analyses presented by Novák et al. (2001). There is relatively small deficiency in the $B$-site, with total ranging from 2.82 to 2.95 apfu. The tetrahedral $T$-sites (Fig. 25) are dominated by $\mathrm{P}$ (1.82-2.00 apfu) and there are variable contents of S to 0.18 apfu (in difference to data by Novák et al. 2001). The (OH) position contains significant fluorine concentrations (Fig. 26), ranging from 0.51 to 1.08 apfu. Baldwin et al. (2000) reported similar high fluorine contents in crandallites from pegmatites in Namibia. The coefficients in empirical formulas corresponding to selected spot analyses of crandallite from Krásno are given in Table 8.

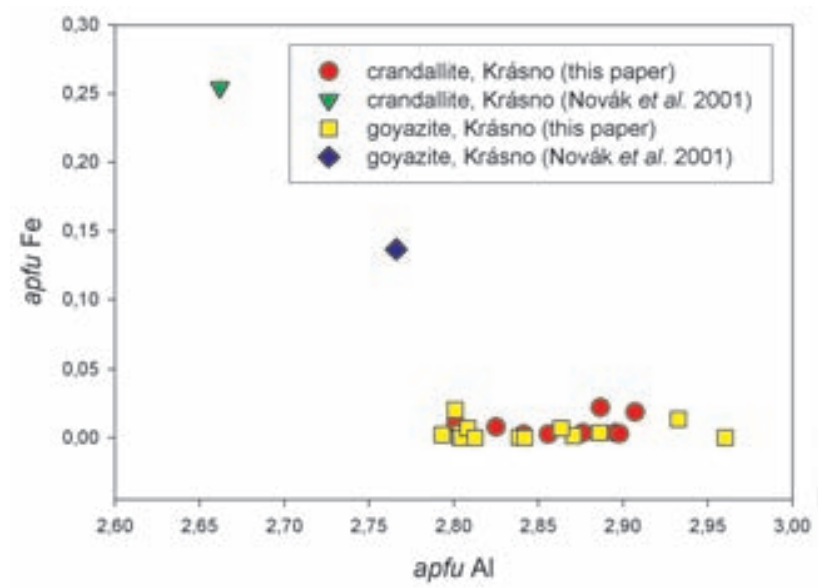

Fig. 24 A plot of apfu Al vs. Fe in B-site of crandallite-type minerals from the Huber open pit, Krásno. The deviation from ideal correlation $\mathrm{Al}+\mathrm{Fe}=3$ is caused by the content of small amounts of $\mathrm{Cu}$ and $\mathrm{Zn}$ and especially the deficit in $B$-site.

Table 7 Unit-cell parameters for crandallite group minerals (for trigonal space group $R-3 m$ )

\begin{tabular}{|lllll|}
\hline & & $\mathrm{a}[\AA]$ & $\mathrm{c}[\AA]$ & $\mathrm{V}\left[\AA^{3}\right]$ \\
\hline crandallite & this paper & $7.000(2)$ & $16.226(9)$ & 688.5 \\
crandallite & Mrázek (1981) & $7.011(2)$ & $16.56(1)$ & 704.9 \\
crandallite Bi- and Sr-rich & Novák et al. $(2001)$ & $7.012(2)$ & $16.650(6)$ & 708.9 \\
goayzite & Novák et al. $(2001)$ & $7.008(2)$ & $16.608(6)$ & 706.4 \\
goayzite & this paper (Schnöd stock) & $6.992(2)$ & $16.537(7)$ & 700.1 \\
goyazite & this paper (Huber stock) & $7.0214(8)$ & $16.507(3)$ & 704.8 \\
\hline
\end{tabular}




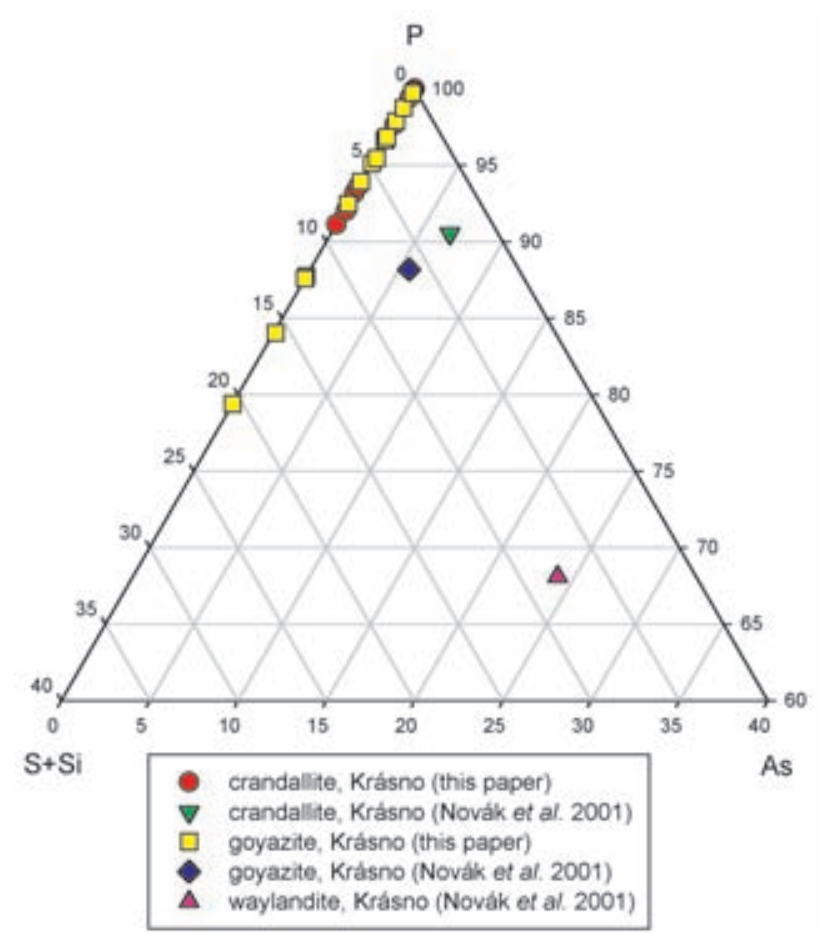

Fig. 25 Part of ternary plot of $T$-sites occupancy (atomic ratio) of crandallite-type minerals from the Huber open pit, Krásno.

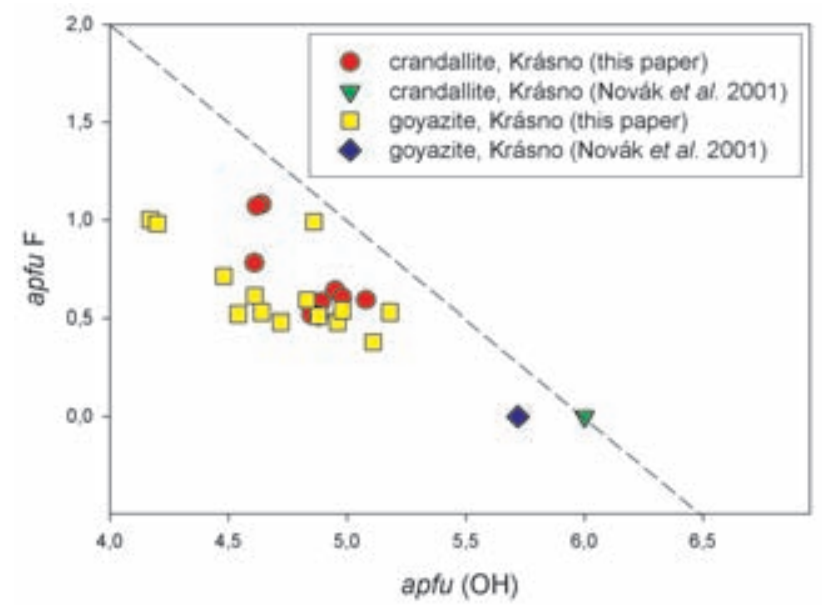

Fig. 26 A plot of apfu $\mathrm{OH} v s$. F in crandallite-type minerals from the Huber open pit, Krásno. The dashed line corresponds to the theoretical relation $(\mathrm{OH})+\mathrm{F}=6$.

\section{Goyazite $\mathrm{SrAl}_{3}\left(\mathrm{PO}_{4}\right)\left(\mathrm{PO}_{3} \mathrm{OH}\right)(\mathrm{OH})_{6}$}

Novák et al. (2001) published the first description of Bi-rich goyazite on the material from the Huber open pit as light pinkish brown or brownish - greyish white kidney-shaped cryptocrystalline aggregates, up to $1 \mathrm{~mm}$ in diameter. They presented its unit-cell parameters (Table 7), and chemical analysis with the following empirical formula based on $2(\mathrm{P}+\mathrm{As}+\mathrm{S}+\mathrm{Si})$ : $\left(\mathrm{Sr}_{0.55} \mathrm{Ca}_{0.38} \mathrm{Bi}_{0.26}\right)_{\Sigma 1.19}\left(\mathrm{Al}_{2.76} \mathrm{Fe}_{0.14} \mathrm{Cu}_{0.07}\right)_{\Sigma 2.97}\left[\left(\mathrm{PO}_{4}\right)_{0.88}\left(\mathrm{PO}_{3} \mathrm{OH}\right)_{0.88}\right.$ $\left.\left(\mathrm{AsO}_{4}\right)_{0.11}\left(\mathrm{SO}_{4}\right)_{0.12}\right]_{\Sigma 1.99}(\mathrm{OH})_{5.72}$.
The present study includes numerous goyazite samples collected at different places of the Huber open pit. Goyazite occurs as equant to spheroidal aggregates (Fig. 27), usually with crystalline surface, up to $2 \mathrm{~mm}$ in size (Fig. 28), on quartz crystals in cavities of coarsegrained quartz gangue. Cassiterite, wolframite and clay minerals are associated. The goyazite aggregates are white or whitish-grey, orange colour of some aggregates is probably caused by film of Fe-oxides. Luster is greasy to vitreous, mineral is transparent only in thin splinters. Compact to finely crystalline, light pink goyazite aggre-

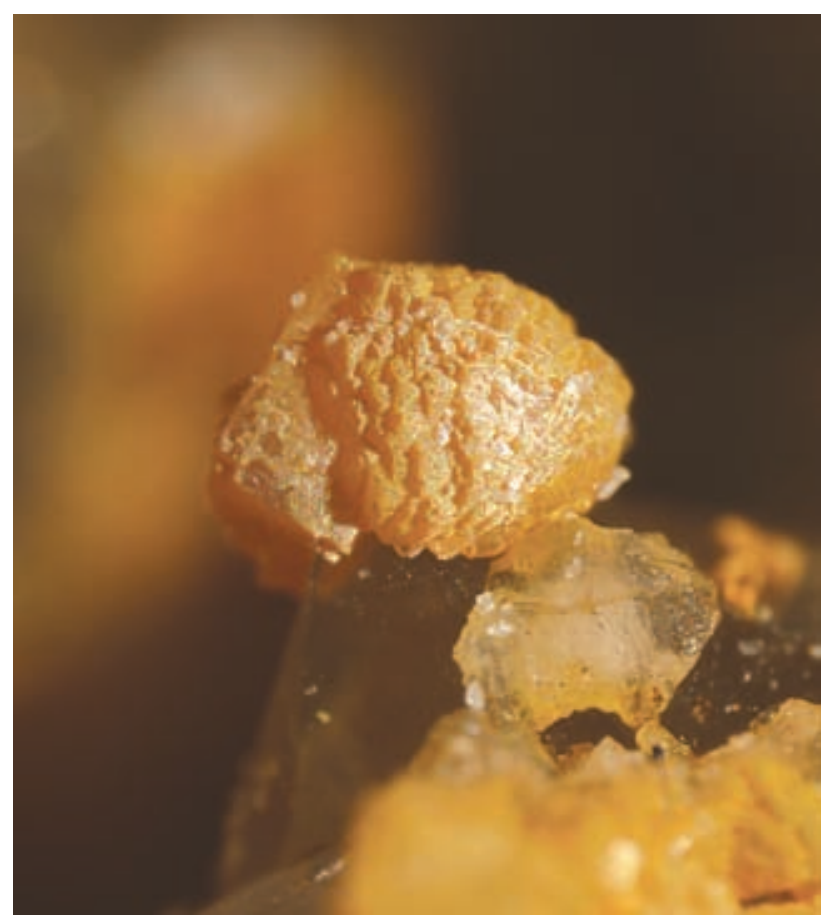

Fig. 27 Semi-spheroidal aggregate of crystalline goyazite growing on quartz crystals. Huber open pit, Krásno. Width of photo $3 \mathrm{~mm}$. Nicon SMZ1500 microphotography by J. \& E. Sejkora.

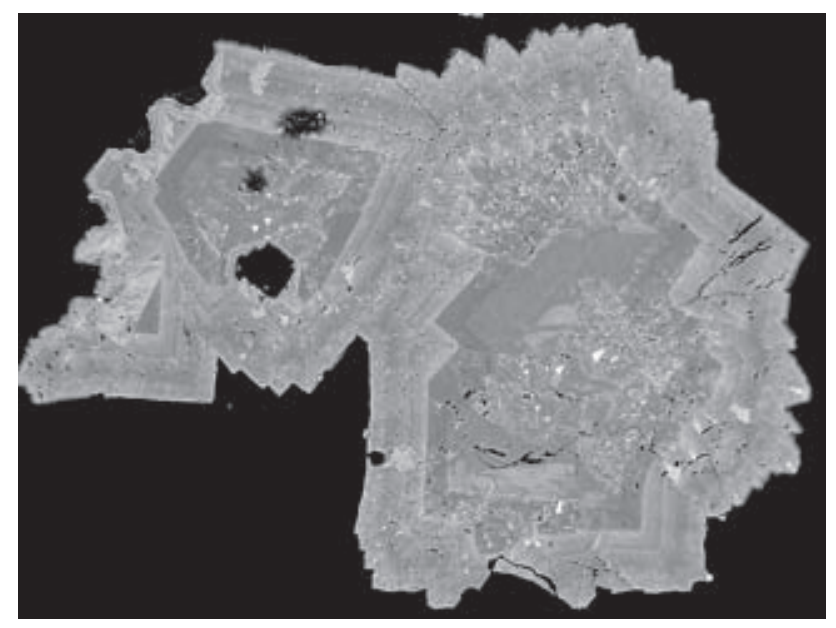

Fig. 28 Strongly zoned aggregate of goyazite crystals (the lighter zones contain higher $\mathrm{Ba}$, darker contain increased $\mathrm{Sr}$ and $\mathrm{Ca}$ ), Huber open pit, Krásno. Width of photo $1500 \mu \mathrm{m}$. BSE photo, Cameca SX100 by J. Sejkora and R. Škoda. 
gates, up to $2 \mathrm{~cm}$ in size, with a weak pearl lustre, are composed of very small (less than $100 \mu \mathrm{m}$ ) trigonal crystals (Fig. 29).

Minerals of crandallite group from the Huber open pit (Fig. 30) include samples with well-formed individual trigonal crystals (Fig. 31), up to $1 \mathrm{~mm}$ in size, and their rich aggregates, up to $1-2 \mathrm{~cm}$ in size. The aggregates are located in cavities of coarse-grained quartz gangue. They are whitish, buff, light pink to red (due to abundant cassiterite and Fe oxide inclusions) and have a vitreous lustre. The studied crystals show oscillatory zoning (Fig. 32); WD line-scans of $\mathrm{Ca}$ and Sr content (Fig. 33) and compositional profiles (Fig. 34) exhibit that numerous zones, less than $2 \mu \mathrm{m}$ in width, in a single crystal correspond alternatively to goyazite or crandallite.
At the VIII ${ }^{\text {th }}$ level of the Schnöd stock goyazite has been found in unusually large, up to $5 \mathrm{~cm}$ long, grapeshaped crystalline aggregates, deposited in cavities in quartz or cavities after leached triplite. The aggregates are light pinkish to buff in colour. Goyazite is associated with chrysocolla, fluorapatite and clay minerals.

X-ray powder data and refined unit-cell parameters (Table 7) correspond to published data for minerals of the goyazite - crandallite series. These data also show that the extensive isomorphism makes X-ray identification of the two mineral species problematic.

With regard to the regular increased contents of $F$, the chemical analyses of goyazite from Krásno (Table 8) were recalculated on the basis of $(\mathrm{P}+\mathrm{As}+\mathrm{S}+\mathrm{Si})=2$. $\mathrm{Sr}$ (0.47-0.84 apfu) is the dominant element in $A$-site of

Table 8 Chemical composition of crandallite and goayzite (in wt. \%)

\begin{tabular}{|c|c|c|c|c|c|c|c|c|c|}
\hline & 1 & 2 & 3 & 4 & 5 & 6 & 7 & 8 & 9 \\
\hline $\mathrm{K}_{2} \mathrm{O}$ & 0.00 & 0.14 & 0.23 & 0.31 & 0.00 & 0.05 & 0.03 & 0.00 & 0.33 \\
\hline $\mathrm{CaO}$ & 6.91 & 10.08 & 10.82 & 10.97 & 4.17 & 0.77 & 0.78 & 0.87 & 2.60 \\
\hline $\mathrm{BaO}$ & 0.49 & 0.25 & 0.32 & 0.25 & 0.55 & 9.14 & 4.38 & 1.27 & 0.00 \\
\hline $\mathrm{SrO}$ & 10.27 & 3.70 & 2.27 & 1.70 & 13.45 & 14.10 & 16.30 & 19.60 & 0.00 \\
\hline $\mathrm{MgO}$ & 0.00 & 0.05 & 0.00 & 0.00 & 0.06 & 0.05 & 0.00 & 0.00 & 0.00 \\
\hline $\mathrm{PbO}$ & 0.00 & 0.00 & 0.02 & 0.06 & 0.12 & 0.14 & 0.42 & 0.00 & 0.00 \\
\hline $\mathrm{CuO}$ & 0.06 & 0.00 & 0.00 & 0.00 & 0.00 & 0.00 & 0.00 & 0.00 & 0.00 \\
\hline $\mathrm{MnO}$ & 0.03 & 0.03 & 0.00 & 0.00 & 0.00 & 0.00 & 0.00 & 0.00 & 0.00 \\
\hline $\mathrm{ZnO}$ & 0.00 & 0.11 & 0.59 & 0.55 & 0.03 & 0.00 & 0.00 & 0.00 & 0.00 \\
\hline $\mathrm{Al}_{2} \mathrm{O}_{3}$ & 33.13 & 33.88 & 33.98 & 34.31 & 33.23 & 32.48 & 32.04 & 32.61 & 17.88 \\
\hline $\mathrm{Fe}_{2} \mathrm{O}_{3}$ & 0.20 & 0.15 & 0.40 & 0.35 & 0.00 & 0.00 & 0.04 & 0.00 & 12.19 \\
\hline $\mathrm{Bi}_{2} \mathrm{O}_{3}$ & 0.00 & 0.00 & 0.03 & 0.23 & 0.02 & 0.09 & 0.02 & 0.00 & 29.13 \\
\hline $\mathrm{SiO}_{2}$ & 0.00 & 0.00 & 0.00 & 0.00 & 0.00 & 0.00 & 0.00 & 0.00 & 1.66 \\
\hline $\mathrm{As}_{2} \mathrm{O}_{5}$ & 0.02 & 0.00 & 0.00 & 0.00 & 0.00 & 0.00 & 0.06 & 0.00 & 9.71 \\
\hline $\mathrm{P}_{2} \mathrm{O}_{5}$ & 32.16 & 33.20 & 32.73 & 32.86 & 32.58 & 29.52 & 30.49 & 27.98 & 17.00 \\
\hline $\mathrm{SO}_{3}$ & 0.85 & 0.22 & 0.05 & 0.00 & 0.47 & 1.16 & 1.59 & 4.47 & 0.00 \\
\hline $\mathrm{F}$ & 2.25 & 3.47 & 4.71 & 4.74 & 2.68 & 4.06 & 4.19 & 2.52 & 0.00 \\
\hline $\mathrm{H}_{2} \mathrm{O} *$ & 12.19 & 11.86 & 11.68 & 11.76 & 11.70 & 11.23 & 10.36 & 11.31 & 9.04 \\
\hline $\mathrm{O}=\mathrm{F}$ & -0.95 & -1.46 & -1.98 & -2.00 & -1.13 & -1.71 & -1.77 & -1.06 & 0.00 \\
\hline total & 97.61 & 95.67 & 95.86 & 96.09 & 97.921 & 01.09 & 98.93 & 99.58 & 99.54 \\
\hline $\mathrm{K}^{+}$ & 0.000 & 0.013 & 0.021 & 0.029 & 0.000 & 0.005 & 0.003 & 0.000 & 0.040 \\
\hline $\mathrm{Ca}^{2+}$ & 0.531 & 0.764 & 0.836 & 0.845 & 0.320 & 0.064 & 0.062 & 0.069 & 0.264 \\
\hline $\mathrm{Ba}^{2+}$ & 0.014 & 0.007 & 0.009 & 0.007 & 0.015 & 0.277 & 0.127 & 0.037 & 0.000 \\
\hline $\mathrm{Sr}^{2+}$ & 0.427 & 0.152 & 0.095 & 0.071 & 0.558 & 0.632 & 0.699 & 0.841 & 0.000 \\
\hline $\mathrm{Mg}^{2+}$ & 0.000 & 0.006 & 0.000 & 0.000 & 0.006 & 0.006 & 0.000 & 0.000 & 0.000 \\
\hline $\mathrm{Pb}^{2+}$ & 0.000 & 0.000 & 0.000 & 0.001 & 0.002 & 0.003 & 0.008 & 0.000 & 0.000 \\
\hline $\mathrm{Cu}^{2+}$ & 0.003 & 0.000 & 0.000 & 0.000 & 0.000 & 0.000 & 0.000 & 0.000 & 0.000 \\
\hline $\mathrm{Mn}^{2+}$ & 0.002 & 0.002 & 0.000 & 0.000 & 0.000 & 0.000 & 0.000 & 0.000 & 0.000 \\
\hline $\mathrm{Zn}^{2+}$ & 0.000 & 0.006 & 0.032 & 0.029 & 0.002 & 0.000 & 0.000 & 0.000 & 0.000 \\
\hline $\mathrm{Bi}^{3+}$ & 0.000 & 0.000 & 0.001 & 0.004 & 0.000 & 0.002 & 0.000 & 0.000 & 0.711 \\
\hline$A$-site & 0.977 & 0.948 & 0.994 & 0.986 & 0.904 & 0.988 & 0.899 & 0.946 & 1.015 \\
\hline $\mathrm{Al}^{3+}$ & 2.801 & 2.825 & 2.887 & 2.907 & 2.804 & 2.960 & 2.793 & 2.842 & 1.995 \\
\hline $\mathrm{Fe}^{3+}$ & 0.011 & 0.008 & 0.022 & 0.019 & 0.000 & 0.000 & 0.002 & 0.000 & 0.868 \\
\hline$B$-site & 2.812 & 2.833 & 2.909 & 2.926 & 2.804 & 2.960 & 2.795 & 2.842 & 2.863 \\
\hline $\mathrm{Si}^{4+}$ & 0.000 & 0.000 & 0.000 & 0.000 & 0.000 & 0.000 & 0.000 & 0.000 & 0.157 \\
\hline $\mathrm{As}^{5+}$ & 0.001 & 0.000 & 0.000 & 0.000 & 0.000 & 0.000 & 0.002 & 0.000 & 0.481 \\
\hline $\mathrm{P}^{5+}\left(\mathrm{PO}_{4}\right)$ & 0.999 & 1.000 & 1.001 & 1.004 & 1.000 & 1.002 & 0.998 & 1.000 & 1.073 \\
\hline $\mathrm{P}^{5+}\left(\mathrm{PO}_{3} \mathrm{OH}\right)$ & 0.954 & 0.989 & 0.997 & 0.996 & 0.975 & 0.931 & 0.911 & 0.752 & 0.289 \\
\hline$S^{6+}$ & 0.046 & 0.011 & 0.003 & 0.000 & 0.025 & 0.067 & 0.088 & 0.248 & 0.000 \\
\hline$T$-site & 2.000 & 2.000 & 2.000 & 2.000 & 2.000 & 2.000 & 2.000 & 2.000 & 2.000 \\
\hline $\mathrm{F}$ & 0.511 & 0.777 & 1.074 & 1.079 & 0.606 & 0.992 & 0.981 & 0.590 & 0.000 \\
\hline $\mathrm{OH}$ & 4.879 & 4.606 & 4.618 & 4.643 & 4.614 & 4.861 & 4.201 & 4.828 & 5.422 \\
\hline $\mathrm{OH}+\mathrm{F}$ site & 5.391 & 5.383 & 5.692 & 5.722 & 5.220 & 5.853 & 5.182 & 5.418 & 5.422 \\
\hline
\end{tabular}

1-4 - representative spot analyses of crandallite, Krásno (this paper)

5-8 - representative spot analyses of goyazite, Krásno (this paper)

9 - waylandite, Krásno (Novák et al. 2001)

Empirical formulas were calculated on the basis of $(\mathrm{P}+\mathrm{As}+\mathrm{Si}+\mathrm{S})=2.00$;

$\mathrm{H}_{2} \mathrm{O}^{*}$ - content is calculated from the ideal formula and charge balance. 


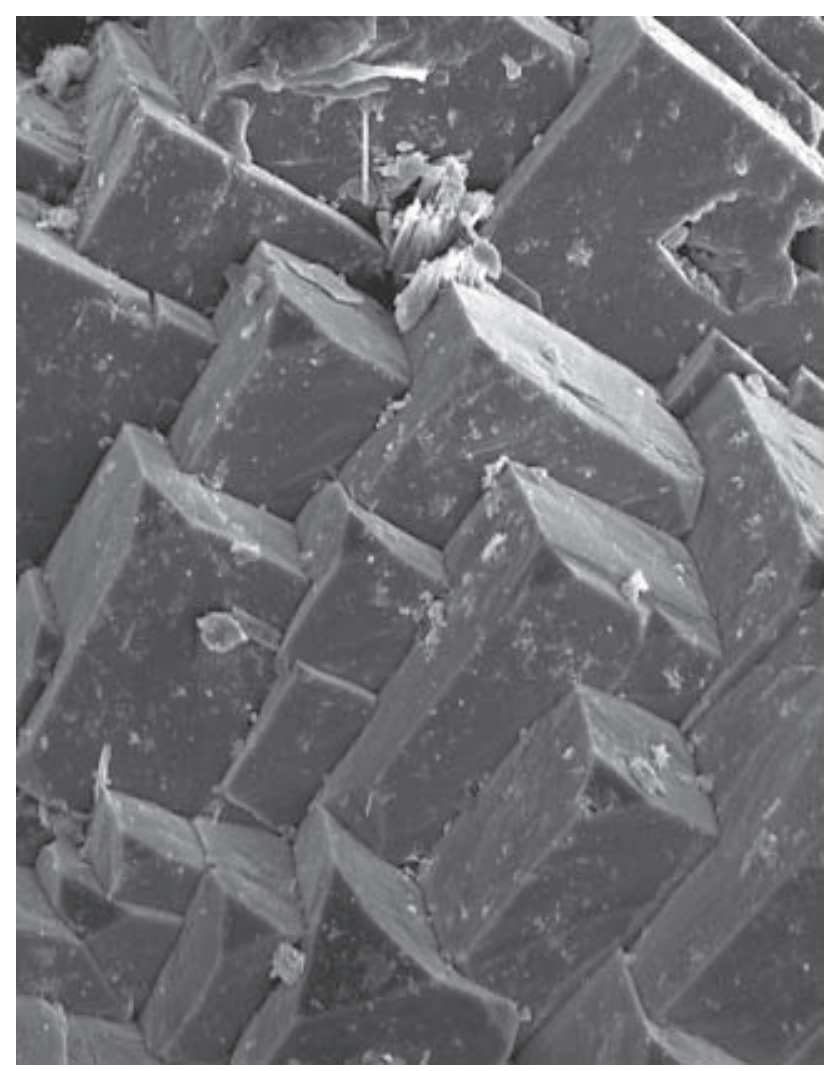

Fig. 29 Trigonal goyazite crystals, Huber open pit, Krásno. Width of photo $60 \mu \mathrm{m}$. SEM photograph by J. Sejkora and J. Plášil.

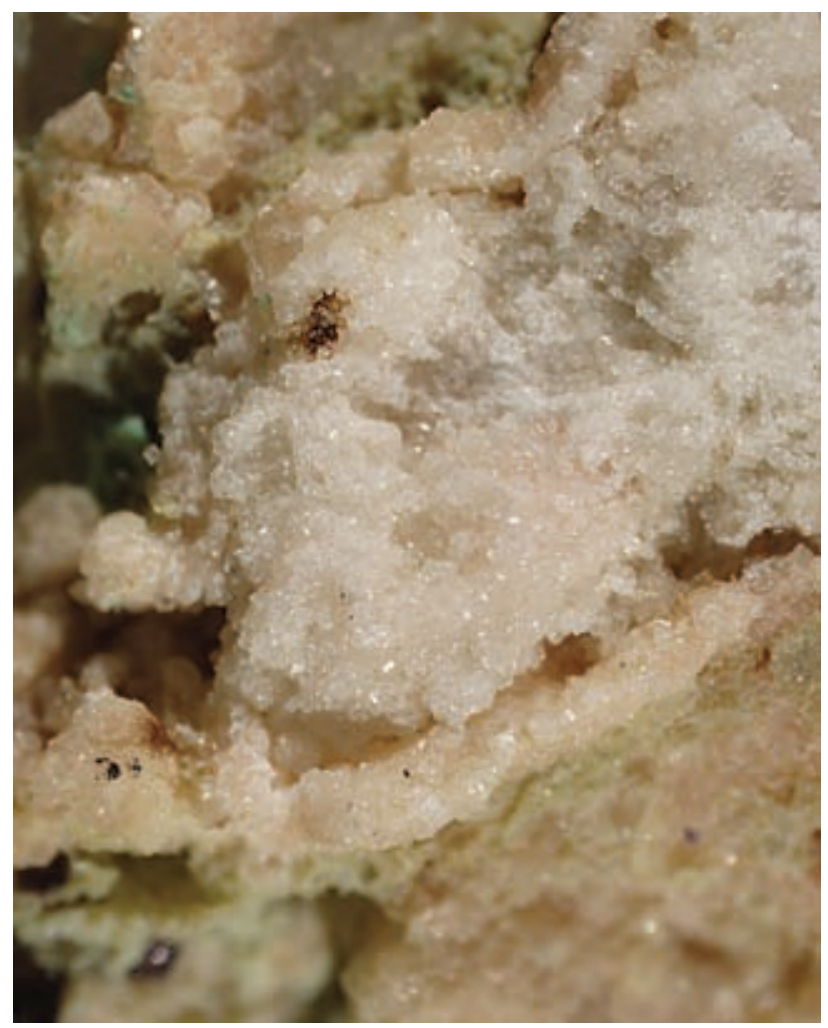

Fig. 30 Rich aggregates of trigonal crystals of crandallite-group minerals, Huber open pit, Krásno. Width of photo $4.5 \mathrm{~mm}$. Nicon SMZ1500 microphotography by J. \& E. Sejkora.

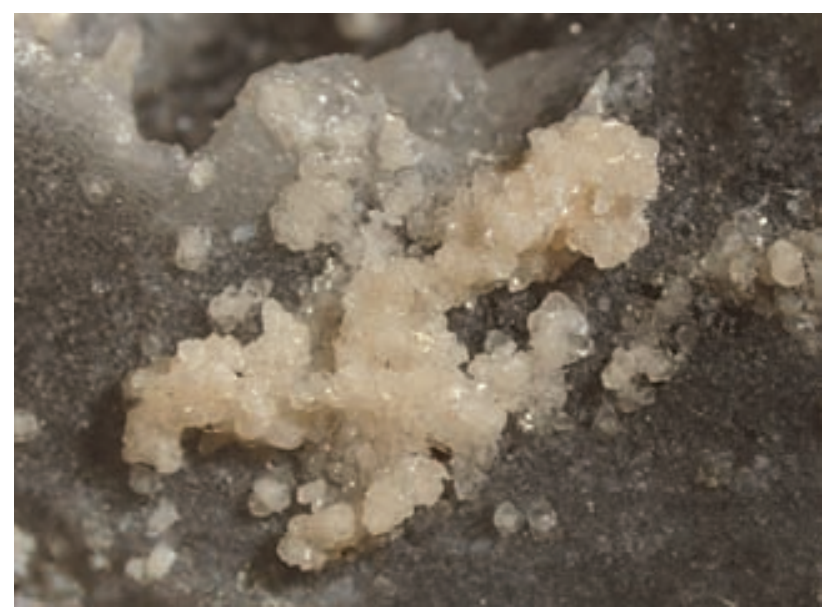

Fig. 31 Strongly zoned crystals of crandallite-goyazite, Huber open pit, Krásno. Width of photo $7 \mathrm{~mm}$. Nicon SMZ1500 microphotography by J. \& E. Sejkora.

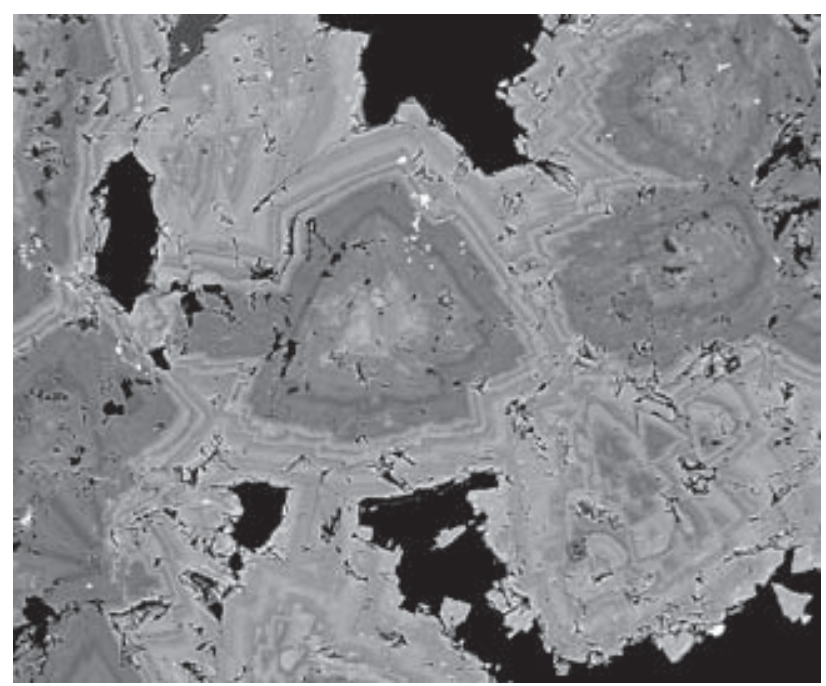

Fig. 32 Group of strongly zoned "crystals" of crandallite-group minerals. The light zones are rich in $\mathrm{Sr}$ (goayzite), dark in $\mathrm{Ca}$ (crandallite); the light minute inclusions belong to cassiterite. Huber open pit, Krásno. Width of photo $600 \mu \mathrm{m}$. BSE photo, Cameca SX100, by J. Sejkora and R. Škoda.

goyazite (Fig. 23), but the contents of the crandallite component (Ca 0.03-0.35 apfu) and gorceixite component (Ba 0.01 to 0.27 apfu) are also significant. The $B$-site in goyazite (Fig. 24), is dominated by $\mathrm{Al}(2.79-2.96 a p f u)$. In difference to data reported by Novák et al. (2001), the Fe contents rarely attain $0.02 \mathrm{apfu}$; the total for atoms in the $B$-site (2.80-2.96 apfu) shows a small deficit compared to the theoretical value. The As-content reported by Novák et al. (2001) has not been found in the present study. Fluorine contents (Fig. 26), ranging from 0.38 to 1.00 apfu, substitute for $(\mathrm{OH})$. Similar contents of $\mathrm{F}$ were reported in goyazite from pegmatites in Namibia (Baldwin et al. 2000) and from carbonatites in Tanzania (McKie 1962). The coefficients in empirical formulas corresponding to selected spot analyses of goyazite from Krásno are given in Table 8. 


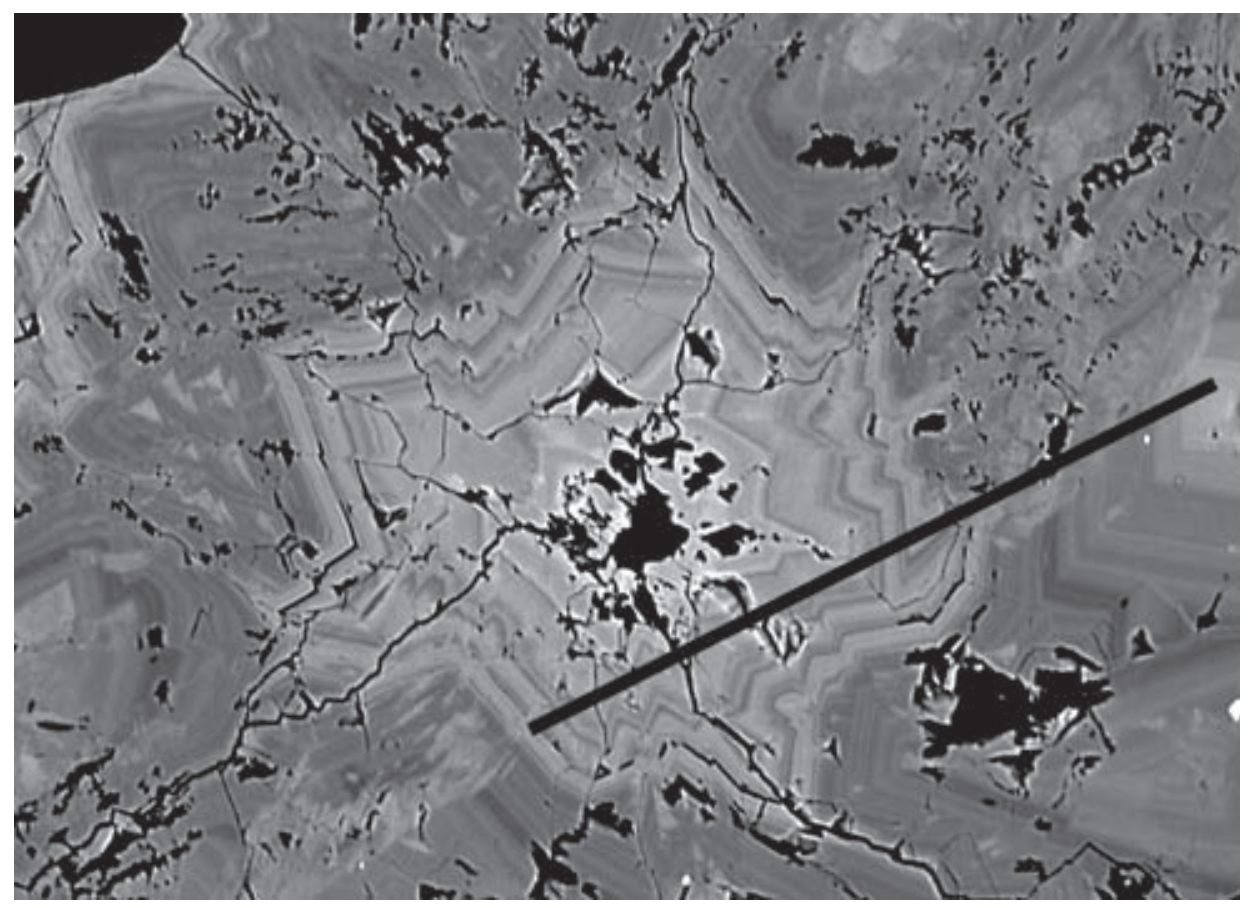

Fig. 33 WD scan of Sr and Ca contents in strongly zoned aggregate composed of goyazite (lighter) and crandallite (darker zones), Huber open pit, Krásno. Width of photo $220 \mu \mathrm{m}$. BSE photo, Cameca SX100, by J. Sejkora and R. Škoda.

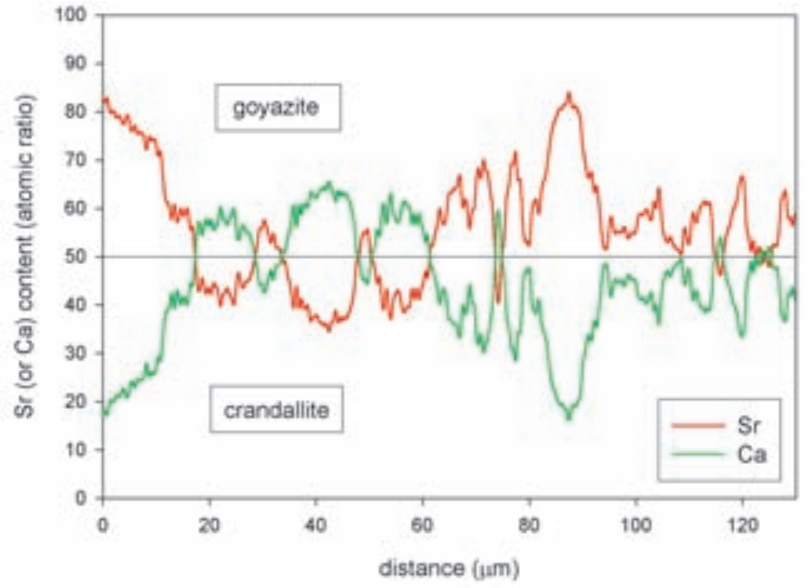

Fig. 34 Profile of $\mathrm{Ca} v s$. Sr contents $(\mathrm{Ca}+\mathrm{Sr}$ atoms $=100$, WD analysis) in strongly zoned "crystal" of crandallite-group minerals. Huber open pit, Krásno.

\section{Waylandite $\mathrm{BiAl}_{3}\left(\mathrm{PO}_{4}\right)_{2}(\mathrm{OH})_{6}$}

Novák et al. (2001) have described waylandite in a sample from the Huber open pit. It forms light yellow brown, mat and partly porous cryptocrystalline aggregates of earthy appearance on cassiterite and quartz. The association includes "varlamoffite" with ca 8 wt. \% Fe, dick-

Table 9 Unit-cell parameters of waylandite (for trigonal space group $R-3 m$ )

\begin{tabular}{|llllrr|}
\hline & & & \multicolumn{1}{c}{$\mathrm{a}[\AA]$} & $\mathrm{c}[\AA]$ & $\mathrm{V}\left[\AA^{3}\right]$ \\
\hline waylandite & Krásno & Novák et al. $(2001)$ & $6.984(2)$ & $16.304(6)$ & 688.7 \\
waylandite & Cornwall & Clark et al. $(1986)$ & $6.9834(3)$ & $16.175(1)$ & 684.1 \\
waylandite & Uganda & Bayliss (1986) & $6.974(1)$ & $16.293(4)$ & 686.3 \\
zairite & Zaire (Congo) & Wambeke (1975) & $7.015(5)$ & $16.37(1)$ & 697.6 \\
\hline
\end{tabular}

ite with muscovite admixture and coatings of rusty brown Fe oxides-hydroxides ("limonite").

Novák et al. (2001) gave for waylandite X-ray powder diffraction data and refined unit-cell parameters (Table 9), which fall between the published data for waylandite and zairite (Bi-Fe-P-dominant member of the crandallite group), closer to waylandite. It is in agreement with the chemical composition of waylandite from Krásno. The chemical analysis of waylandite (Table 8, Novák et al. 2001) yielded on the basis of $2(\mathrm{P}+\mathrm{As}+\mathrm{Si})$ the following crystallochemical formula: $\left(\mathrm{Bi}_{0.71} \mathrm{Ca}_{0.26} \mathrm{~K}_{0.04}\right)_{\Sigma 1.01}$ $\left(\mathrm{Al}_{1.99} \mathrm{Fe}_{0.87}\right)_{\Sigma 2.86}\left[\left(\mathrm{PO}_{4}\right)_{1.07}\left(\mathrm{AsO}_{4}\right)_{0.48}\left(\mathrm{PO}_{3} \mathrm{OH}\right)_{0.29}\left(\mathrm{SiO}_{4}\right)_{0.16}\right]_{\Sigma 2.00}$ $(\mathrm{OH})_{5.42}$. A similar content of crandallite component (0.26 apfu $\mathrm{Ca}$ in $A$-site in sample from Krásno) in waylandite was reported in samples from Uganda (Knorring - Mrose 1963) and Namibia (Blass - Wittern 1994). The $B$-site contains notable Fe (0.87 apfu), which has not been reported yet for waylandite.

\section{Earlshannonite $\mathrm{Mn}^{2+} \mathrm{Fe}^{3+}{ }_{2}\left(\mathrm{PO}_{4}\right)_{2}(\mathrm{OH})_{2} \cdot 4 \mathrm{H}_{2} \mathrm{O}$ Whitmoreite $\mathrm{Fe}^{2+} \mathrm{Fe}^{3+}{ }_{2}\left(\mathrm{PO}_{4}\right)_{2}(\mathrm{OH})_{2} \cdot 4 \mathrm{H}_{2} \mathrm{O}$ (arthurite group)}

Minerals of the arthurite group occur in samples of phosphate accumulations from the Huber open pit in two different mineral associations. The first one consists of irregular whitmoreite aggregates, up to $100 \mu \mathrm{m}$ in size (Fig. 35), which are replaced by younger phases UNK1 and UNK3 (Sejkora et al. 2006), and themself replace aggregates of older isokite and fluorapatite. 
Fig. 35 Complicated aggregate of phosphates from the Huber open pit, Krásno. The oldest mineral fluorapatite $(\mathrm{F})$ is replaced by isokite (I), aggregate of these two minerals is in turn replaced by whitmoreite $(*)$, which contains abundant grains of $U N K 3$ (very light) and it is itself replaced by the youngest phase UNK1 (aggregates of dark tabular crystals). Width of photo $600 \mu \mathrm{m}$. Cameca SX100, BSE photograph by J. Sejkora and R. Škoda.

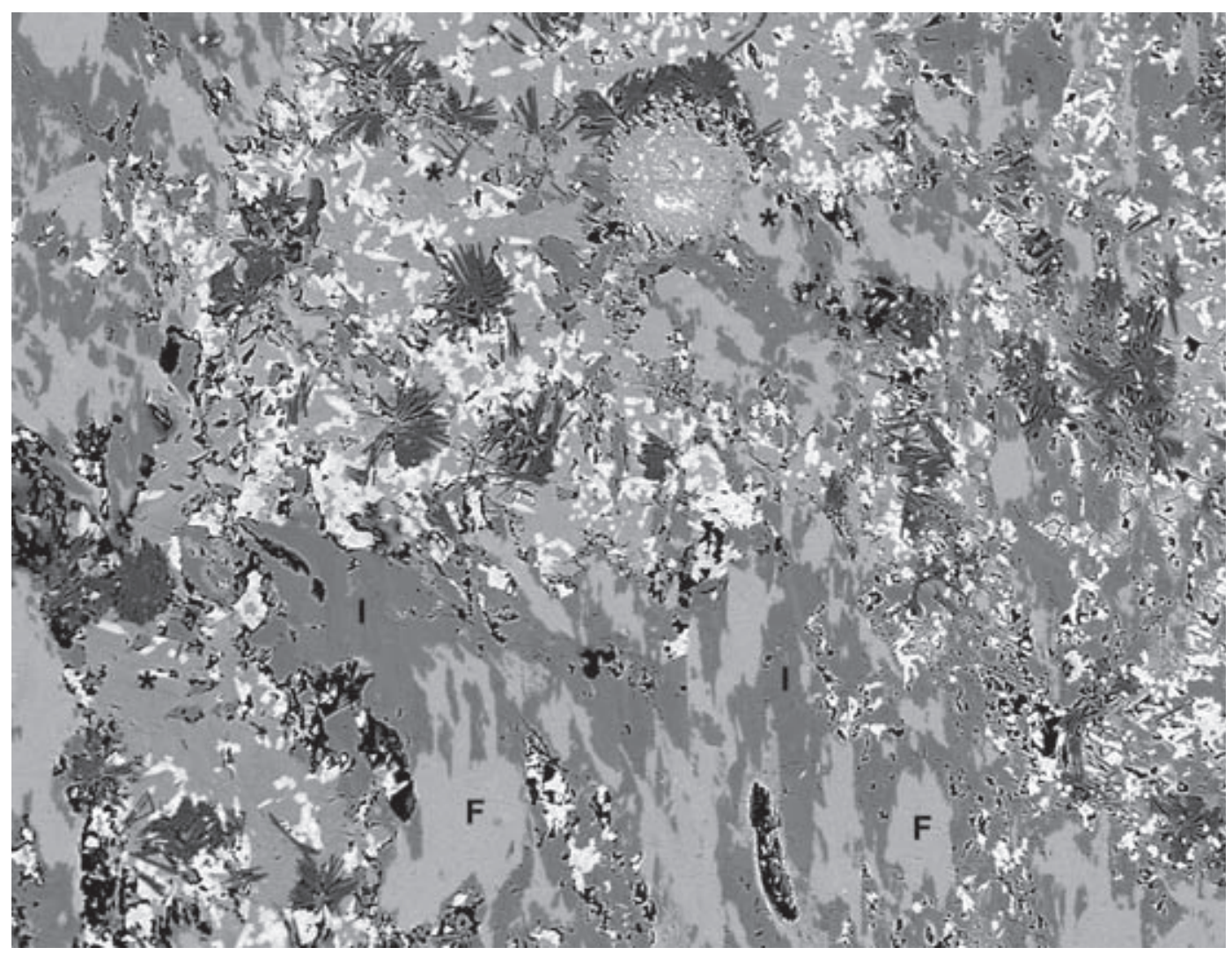

The second mineral association occurs in cavities, 2 up to $3 \mathrm{~cm}$ in diameter, in triplite accumulations, almost completely altered to compact pink brown fluorapatite. Minerals of the arthurite group are accompanied by abundant, well-formed translucent leucophosphite crystals, younger fluorapatite crystals or aggregates, less common minerals of the chalkosiderite - turquoise group, and rare white skeletal aggregates of UNK1. Whitmoreite forms rare translucent, colourless to very light yellow-green tabular to lath-shaped crystals, up to $0.1 \mathrm{~mm}$ long. It is intergrown with yellow-green phase UNK6 showing the same morphology, and darker green $U N K 7$ grouped to small radiating aggregates or random crystal clusters. Crystals show distinct colour zoning, with lighter green zones (whitmoreite, earlshannonite, UNK8) and darker green zones (UNK7). Material with chemical composition corresponding to $\mathrm{Zn}$ - and $\mathrm{Mg}$-rich earlshannonite has been found in this association only as very tiny and irregular (to $10 \mu \mathrm{m}$ ) zone in aggregate of whitmoreite and UNK7 (Sejkora et al. 2006).

Due to small dimensions of earlshannonite and whitmoreite, it was not possible to examine these phases by $\mathrm{X}$-ray powder diffraction. Their classification with the arthurite group is based mainly on stoichiometry and their intergrowths with, and even distinct zones within, crystals of other members of the arthurite group (UNK6, UNK7, UNK8 - Sejkora et al. 2006).

The chemical composition of the arthurite group minerals can be expressed by a general formula
$A B_{2}\left(\mathrm{TO}_{4}\right)_{2}(\mathrm{OH}, \mathrm{O})_{2} \cdot 4 \mathrm{H}_{2} \mathrm{O}$. A detailed characteristics of occupancy of individual sites is given in description of the new mineral species UNK6 (Sejkora et al. 2006). Two chemically distinct verieties of whitmoreite from Krásno have been found (Table 10). The $A$-site in $\mathrm{Cu}$-rich whitmoreite (Fig. 36) contains dominant $\mathrm{Fe}^{2+}(0.84-0.88$ apfu)

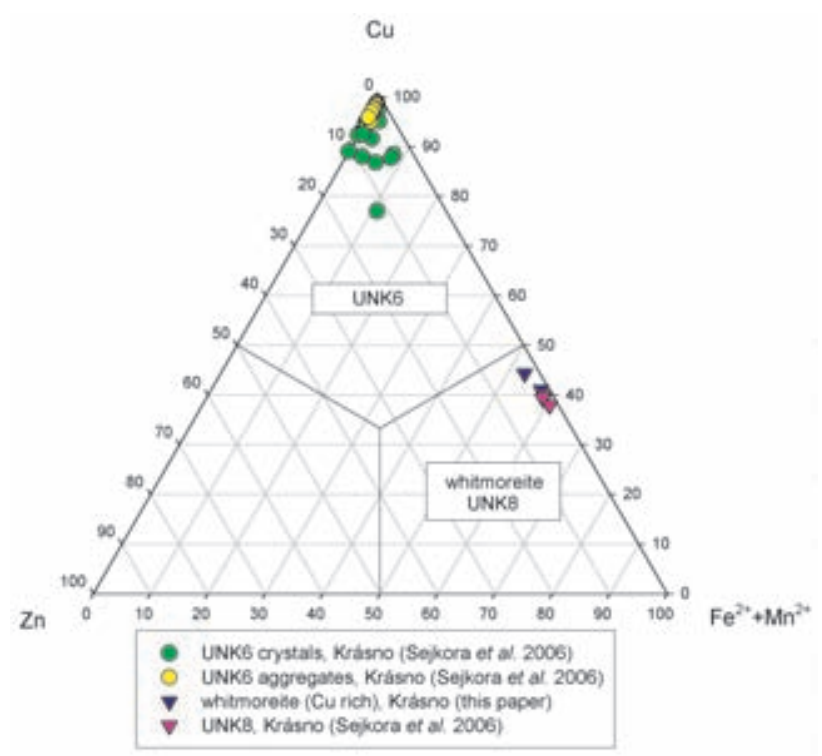

Fig. 36 Ternary plot of $A$-site occupancy by $\mathrm{Cu}-\mathrm{Zn}-\left(\mathrm{Fe}^{2+}+\mathrm{Mn}^{2+}\right)$ (atomic ratio) for arthurite group mineral phases (Cu-rich whitmoreite, UNK6, UNK8) from Krásno. 
and significant $\mathrm{Cu}$ ranging from 0.63 to 0.71 apfu. The $B$-site contains $\mathrm{Fe}^{3+}$ (1.32-1.49 apfu), Al (0.44-0.55 apfu) and Ti (0.06-0.13 apfu). Phosphorus in tetrahedral $T$-site (1.94 apfu) strongly predominates over As (0.06 apfu). The chemical composition of $\mathrm{Cu}$-rich whitmoreite can be expressed by the empirical formula $\left(\mathrm{Fe}^{2+}{ }_{0.87} \mathrm{Cu}_{0.67} \mathrm{Zn}_{0.03}\right)_{\Sigma 1.57}$ $\left(\mathrm{Fe}^{3+}{ }_{1.41} \mathrm{Al}_{0.50} \mathrm{Ti}_{0.10}\right)_{\Sigma 2.01}\left[\left(\mathrm{PO}_{4}\right)_{1.94}\left(\mathrm{AsO}_{4}\right)_{0.06}\right]_{\Sigma 2.00}(\mathrm{OH})_{3.27}$. $4.00 \mathrm{H}_{2} \mathrm{O}$.

$\mathrm{Cu}$-poor whitmoreite contains in $A$-site (Fig. 37) only a minor amounts of $\mathrm{Cu}$ (up to $0.02 \mathrm{apfu}$ ) and increased $\mathrm{Zn}\left(0.15-0.41\right.$ apfu), besides the dominant $\mathrm{Fe}^{2+}(0.40$ 0.69 apfu). This probably suggests only a limited isomorphous substitution of $\mathrm{Fe}^{2+}$ by $\mathrm{Cu}$ and $\mathrm{Zn}$ in arthurite group minerals. $\mathrm{Fe}^{3+}(1.40-1.95$ apfu $)$ is the dominant element in the $B$-site (Fig. 38). The tetrahedral $T$-site is commonly dominated by $\mathrm{P}$ (1.96-1.98 apfu) but As-rich members (As 0.56-0.79 apfu) containing $\mathrm{P}$ in the range 1.20-1.43 apfu also occur (Fig. 39). The empirical formula of As-rich members is on the basis of $(\mathrm{P}+\mathrm{As}+\mathrm{S}+\mathrm{Si})=2$ $\left(\mathrm{Fe}^{2+}{ }_{0.49} \mathrm{Zn}_{0.37} \mathrm{Na}_{0.03} \mathrm{Mn}_{0.02} \mathrm{Mg}_{0.01} \mathrm{Cu}_{0.01}\right)_{\Sigma 0.93}\left(\mathrm{Fe}^{3+}{ }_{1.91} \mathrm{Al}_{0.07} \mathrm{Ti}_{0.01}\right)_{\Sigma 1.99}$ $\left[\left(\mathrm{PO}_{4}\right)_{1.28}\left(\mathrm{AsO}_{4}\right)_{0.72}\right]_{\Sigma 2.00}(\mathrm{OH})_{1.86} \cdot 4.00 \mathrm{H}_{2} \mathrm{O}$.

The $A$-site in $\mathrm{Zn}$ - and $\mathrm{Mg}$-rich earlshannonite (Table 10) is dominated by $\mathrm{Mn}^{2+}(0.37 \mathrm{apfu})$ and contains significant $\mathrm{Zn}$ (0.33 apfu), $\mathrm{Mg}$ (0.22 apfu) and $\mathrm{Fe}^{2+}(0.12$ apfu). The $B$-site is occupied mainly by $\mathrm{Fe}^{3+}$ (1.94 apfu) and the tetrahedral $T$-site contains P (1.80 apfu) predominating over As (0.19 apfu). The empirical formula on the basis of $(\mathrm{P}+\mathrm{As}+\mathrm{S}+\mathrm{Si})=2$ is $\left(\mathrm{Mn}_{0.37} \mathrm{Zn}_{0.33} \mathrm{Mg}_{0.22} \mathrm{Fe}^{2+}{ }_{0.13}\right.$ $\left.\mathrm{Cu}_{0.03} \mathrm{Na}_{0.02}\right)_{\Sigma 1.10}\left(\mathrm{Fe}_{1.94} \mathrm{Al}_{0.03} \mathrm{Ti}_{0.03}\right)_{\Sigma 2.00}\left[\left(\mathrm{PO}_{4}\right)_{1.80}\left(\mathrm{AsO}_{4}\right)_{1.20}\right]_{\Sigma 2.00}$ $(\mathrm{OH})_{2.29} \cdot 4.00 \mathrm{H}_{2} \mathrm{O}$.

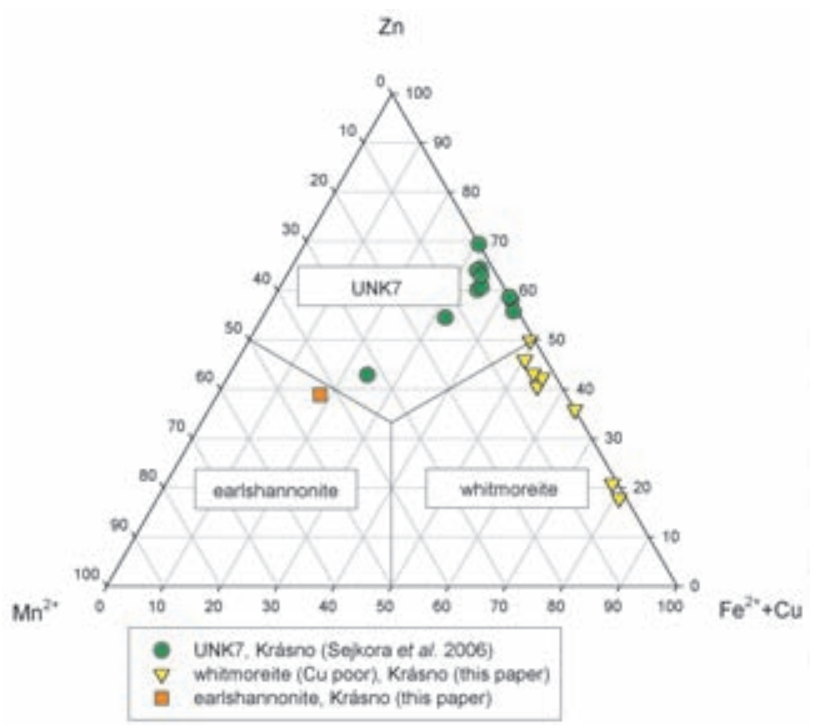

Fig. 37 Ternary plot of $A$-site occupancy by $\mathrm{Zn}-\mathrm{Mn}^{2+}-\left(\mathrm{Fe}^{2+}+\mathrm{Cu}\right)$ (atomic ratio) for arthurite group mineral phases ( $\mathrm{Cu}$-poor whitmoreite, earlshannonite, UNK7) from Krásno.

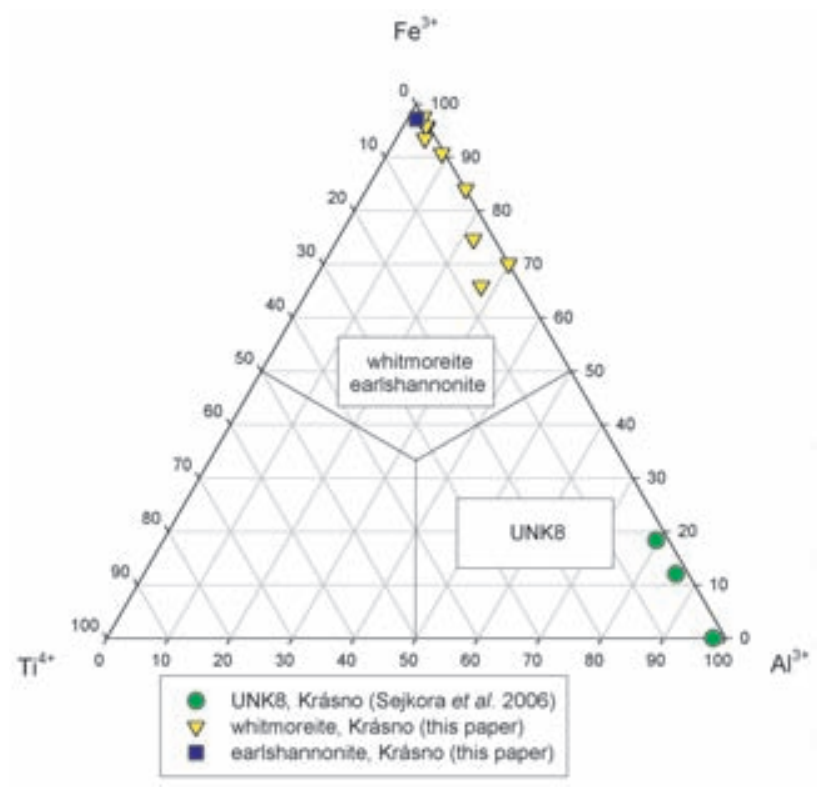

Fig. 38 Ternary plot of $B$-site occupancy by $\mathrm{Fe}^{3+}-\mathrm{Ti}-\mathrm{Al}$ (atomic ratio) for arthurite-group mineral phases (whitmoreite, earlshannonite, UNK8) from Krásno.

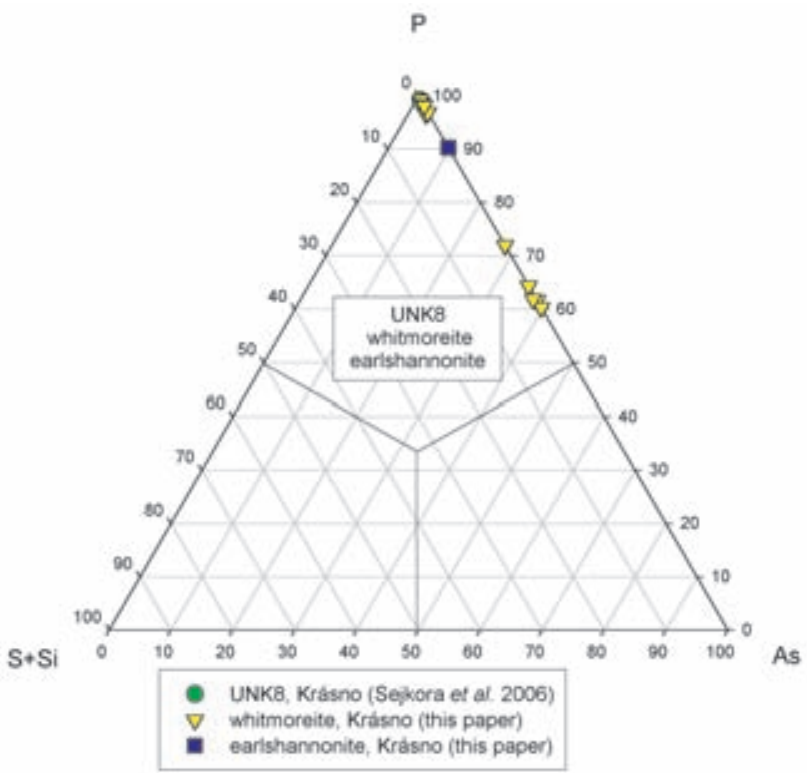

Fig. 39 Ternary plot of $T$-site occupancy by $\mathrm{P}-(\mathrm{S}+\mathrm{Si})-\mathrm{As}$ (atomic ratio) for arthurite group mineral phases (whitmoreite, earlshannonite, $U N K 8)$ from Krásno.

\section{Fluellite $\mathrm{Al}_{2}\left(\mathrm{PO}_{4}\right) \mathrm{F}_{2}(\mathrm{OH}) \cdot 7 \mathrm{H}_{2} \mathrm{O}$}

Fluellite has been rarely found in cavities, 1 to $5 \mathrm{~cm}$ across, in coarse-grained quartz at several places of the Huber open pit. It usually forms inconspicuous perfect 
Table 10 Chemical composition of whitmoreite and earlshannonite (in wt. \%)

\begin{tabular}{|c|c|c|c|c|c|c|c|c|}
\hline & 1 & 2 & 3 & 4 & 5 & 6 & 7 & 8 \\
\hline $\mathrm{Na}_{2} \mathrm{O}$ & 0.16 & 0.01 & 0.00 & 0.02 & 0.20 & 0.21 & 0.14 & 0.33 \\
\hline $\mathrm{K}_{2} \mathrm{O}$ & 0.06 & 0.06 & 0.05 & 0.07 & 0.03 & 0.01 & 0.05 & 0.07 \\
\hline $\mathrm{CuO}$ & 0.48 & 10.72 & 10.13 & 11.32 & 0.18 & 0.09 & 0.38 & 0.00 \\
\hline $\mathrm{MnO}$ & 5.51 & 0.02 & 0.00 & 0.03 & 0.34 & 0.52 & 0.31 & 0.45 \\
\hline $\mathrm{ZnO}$ & 5.68 & 0.55 & 0.38 & 0.71 & 5.95 & 5.61 & 5.88 & 6.35 \\
\hline $\mathrm{BaO}$ & 0.09 & 0.06 & 0.00 & 0.13 & 0.04 & 0.09 & 0.00 & 0.00 \\
\hline $\mathrm{SrO}$ & 0.01 & 0.05 & 0.11 & 0.00 & 0.02 & 0.00 & 0.02 & 0.02 \\
\hline $\mathrm{CaO}$ & 0.45 & 0.04 & 0.06 & 0.02 & 0.07 & 0.06 & 0.10 & 0.03 \\
\hline $\mathrm{PbO}$ & 0.00 & 0.12 & 0.11 & 0.13 & 0.01 & 0.00 & 0.00 & 0.04 \\
\hline $\mathrm{MgO}$ & 1.90 & 0.00 & 0.00 & 0.00 & 0.11 & 0.02 & 0.00 & 0.14 \\
\hline $\mathrm{FeO}^{*}$ & 1.89 & 12.49 & 12.81 & 12.18 & 6.97 & 6.69 & 6.43 & 6.14 \\
\hline $\mathrm{Fe}_{2} \mathrm{O}_{3} *$ & 32.72 & 22.55 & 23.92 & 21.17 & 30.53 & 30.62 & 31.15 & 30.66 \\
\hline $\mathrm{Al}_{2} \mathrm{O}_{3}$ & 0.32 & 5.08 & 4.49 & 5.66 & 0.76 & 0.79 & 0.81 & 0.97 \\
\hline $\mathrm{SiO}_{2}$ & 0.05 & 0.02 & 0.02 & 0.02 & 0.04 & 0.05 & 0.05 & 0.02 \\
\hline $\mathrm{TiO}_{2}$ & 0.48 & 1.60 & 1.09 & 2.11 & 0.22 & 0.18 & 0.16 & 0.61 \\
\hline $\mathrm{As}_{2} \mathrm{O}_{5}$ & 4.70 & 1.40 & 1.35 & 1.45 & 16.47 & 16.42 & 17.97 & 13.24 \\
\hline $\mathrm{P}_{2} \mathrm{O}_{5}$ & 26.98 & 27.60 & 27.54 & 27.66 & 18.16 & 18.28 & 17.81 & 20.94 \\
\hline $\mathrm{SO}_{3}$ & 0.02 & 0.05 & 0.11 & 0.00 & 0.00 & 0.00 & 0.00 & 0.00 \\
\hline $\mathrm{H}_{2} \mathrm{O}^{* *}$ & 19.92 & 20.31 & 20.24 & 20.38 & 18.57 & 18.56 & 18.50 & 18.90 \\
\hline total & 101.40 & 102.73 & 102.40 & 103.06 & 98.63 & 98.19 & 99.75 & 98.90 \\
\hline $\mathrm{Na}$ & 0.024 & 0.002 & 0.000 & 0.004 & 0.032 & 0.033 & 0.022 & 0.052 \\
\hline $\mathrm{K}$ & 0.006 & 0.006 & 0.005 & 0.008 & 0.003 & 0.001 & 0.005 & 0.007 \\
\hline $\mathrm{Ca}$ & 0.038 & 0.003 & 0.005 & 0.002 & 0.006 & 0.006 & 0.009 & 0.003 \\
\hline $\mathrm{Fe}^{2+}$ & 0.125 & 0.865 & 0.888 & 0.842 & 0.485 & 0.464 & 0.439 & 0.417 \\
\hline $\mathrm{Ba}$ & 0.003 & 0.002 & 0.000 & 0.004 & 0.001 & 0.003 & 0.000 & 0.000 \\
\hline $\mathrm{Sr}$ & 0.000 & 0.003 & 0.005 & 0.000 & 0.001 & 0.000 & 0.001 & 0.001 \\
\hline $\mathrm{Mg}$ & 0.223 & 0.000 & 0.000 & 0.000 & 0.013 & 0.002 & 0.000 & 0.017 \\
\hline $\mathrm{Pb}$ & 0.000 & 0.003 & 0.003 & 0.003 & 0.000 & 0.000 & 0.000 & 0.001 \\
\hline $\mathrm{Cu}$ & 0.028 & 0.671 & 0.634 & 0.707 & 0.011 & 0.005 & 0.023 & 0.000 \\
\hline $\mathrm{Mn}$ & 0.368 & 0.001 & 0.000 & 0.002 & 0.024 & 0.036 & 0.021 & 0.031 \\
\hline $\mathrm{Zn}$ & 0.331 & 0.033 & 0.023 & 0.043 & 0.365 & 0.344 & 0.354 & 0.380 \\
\hline$A$ total & 1.146 & 1.589 & 1.564 & 1.614 & 0.941 & 0.895 & 0.874 & 0.908 \\
\hline $\mathrm{Al}^{3+}$ & 0.030 & 0.495 & 0.439 & 0.552 & 0.074 & 0.077 & 0.078 & 0.093 \\
\hline $\mathrm{Fe}^{3+}$ & 1.942 & 1.405 & 1.493 & 1.317 & 1.912 & 1.911 & 1.912 & 1.870 \\
\hline $\mathrm{Ti}^{4+}$ & 0.028 & 0.100 & 0.068 & 0.131 & 0.014 & 0.011 & 0.010 & 0.037 \\
\hline$B$ total & 2.000 & 2.000 & 2.000 & 2.000 & 2.000 & 2.000 & 2.000 & 2.000 \\
\hline $\mathrm{Si}$ & 0.004 & 0.001 & 0.002 & 0.001 & 0.003 & 0.004 & 0.004 & 0.002 \\
\hline As & 0.194 & 0.061 & 0.058 & 0.063 & 0.717 & 0.712 & 0.766 & 0.561 \\
\hline $\mathrm{P}$ & 1.801 & 1.935 & 1.933 & 1.936 & 1.280 & 1.284 & 1.230 & 1.437 \\
\hline $\mathrm{S}$ & 0.001 & 0.003 & 0.007 & 0.000 & 0.000 & 0.000 & 0.000 & 0.000 \\
\hline$T$ total & 2.000 & 2.000 & 2.000 & 2.000 & 2.000 & 2.000 & 2.000 & 2.000 \\
\hline $\mathrm{H}$ & 10.282 & 11.271 & 11.197 & 11.345 & 9.854 & 9.769 & 9.726 & 9.795 \\
\hline $\mathrm{OH}$ & 2.287 & 3.272 & 23.196 & 3.348 & 1.859 & 1.762 & 1.727 & 1.792 \\
\hline $\mathrm{H}_{2} \mathrm{O}$ & 3.997 & 3.999 & 4.000 & 3.998 & 3.998 & 4.003 & 4.000 & 4.001 \\
\hline
\end{tabular}

Empirical formulas were calculated on the basis of $(\mathrm{P}+\mathrm{As}+\mathrm{Si}+\mathrm{S})=2.00$;

* - calculation of $\mathrm{Fe}_{\text {tot }}$ to $\mathrm{Fe}^{2+}$ and $\mathrm{Fe}^{3+}$ is based on the assumption that $\mathrm{Fe}^{3+}$ (together with $\mathrm{Al}^{3+}$ and $\mathrm{Ti}^{4+}$ ) completely fills the $\mathrm{B}^{3+}$ position and only the surplus $\mathrm{Fe}$ (above 2 pfu) enters the site $\mathrm{A}^{2+}$ as $\mathrm{Fe}^{2+}$;

$* *-\mathrm{H}_{2} \mathrm{O}$ content is calculated from the ideal formula $\left(\mathrm{H}_{2} \mathrm{O}=4.00\right)$ and charge balance. 1 - earlshannonite (spot analysis); 2 - Cu-rich whitmoreite (mean of two spot analyses); 5 - Cu-poor whitmoreite (mean of nine spot analyses); 3, 4, 6, 7, 8- selected spot analyses of whitmoreite.

dipyramidal crystals, up to $1 \mathrm{~cm}$ in size (Fig. 40). They are very brittle, water-clear and translucent or slightly turbid to white and transparent, with an intense vitreous lustre. Fluellite is associated with quartz, white and violet fluorite, colourless to light yellowish topaz crystals, cassiterite, wavellite and dickite.

X-ray powder data of fluellite from Krásno (Table 11) and its refined unit-cell parameters (Table 12) are in good agreement with published data. The quantitative chemical analyses yielded $\mathrm{Al}_{2} \mathrm{O}_{3}, \mathrm{P}_{2} \mathrm{O}_{5}$ and $\mathrm{F}$ only (Table 13). Calculation of the theoretical content of $\mathrm{H}_{2} \mathrm{O}$ corresponding to ideal formula provided the total near $120 \mathrm{wt} . \%$.
It indicates a strong dehydration, corresponding to loss of two $\mathrm{H}_{2} \mathrm{O}$ molecules during sample coating in vacuum and analysis. This loss is indicated by irregular fracturing of the analyzed samples. The empirical formula of fluellite calculated on the basis of $14(\mathrm{O}, \mathrm{OH}, \mathrm{F})$ is $\mathrm{Al}_{1.98}\left(\mathrm{PO}_{4}\right)_{1.07} \mathrm{~F}_{1.99}(\mathrm{OH})_{0.75} \cdot 7 \mathrm{H}_{2} \mathrm{O}$, close to the ideal formula.

\section{Fluorapatite $\mathrm{Ca}_{5}\left(\mathrm{PO}_{4}\right)_{3}(\mathrm{~F}, \mathrm{Cl}, \mathrm{OH})$}

Fluorapatite is the most widespread phosphate in the Krásno ore district. It occurs in a variety of morphological forms and is abundant in all its parts (Beran 1999; Beran - Sejkora 2006). In the course of the present study fluorapatite occurrences in phosphate accumulations and their surrounding have been examined in detail. Four types of fluorapatite were recognized with regard to morphological character and position in mineral association:

a) Fluorapatite I forms dark green, exceptionally yellow, grey to black coarse-grained aggregates with grains up to $5 \mathrm{~cm}$, intergrown in white quartz in proximity of phosphate accumulations. In contrast to phosphate accumulation located only 5-20 $\mathrm{mm}$ aside, this fluorapatite is not altered by hydrothermal or supergene processes.

b) Fluorapatite II is represented by compact to very fine-grained aggregates of red-brown to brown colour, from several $\mathrm{mm}$ to over $1 \mathrm{~m}$ in size. Light pink, pink-brown and light brown colour of the aggregates is less common. This fluorapatite is intergrown with white compact or coarse-grained quartz. Aggregates often contain relics and nests of triplite (or zwieselite) of variable colour. Detailed study indicates that fluorapatite II intensively replaced triplite (or zwieselite) and it is in turn extensively replaced by isokite. This process results in aggregates composed of predominant isokite and showing variable textures. Compact fluorapatite aggregates of white, grey or light green colour, replaced in some instances by minerals of the rockbridgeite - frondelite series, morinite, phosphosiderite, and UNK3 are less common. The compact type of fluorapatite II shows tendency to late hydrothermal or supergene alterations, resulting in cavities more than $10 \mathrm{~cm}$ across.

c) Fluorapatite III was found in leached cavities in phosphate accumulations. It forms abundant corroded relics, aggregates and particularly white powdery coatings or filling. Fluorapatite III here also forms colourless, grey, or light pink fine acicular crystals with a silky lustre and colourless, white beige, grey, light pink or greenish tabular to columnar crystals to $1 \mathrm{~mm}$ in size, grouped in small aggregates. Leucophosphite, pharmaco- 


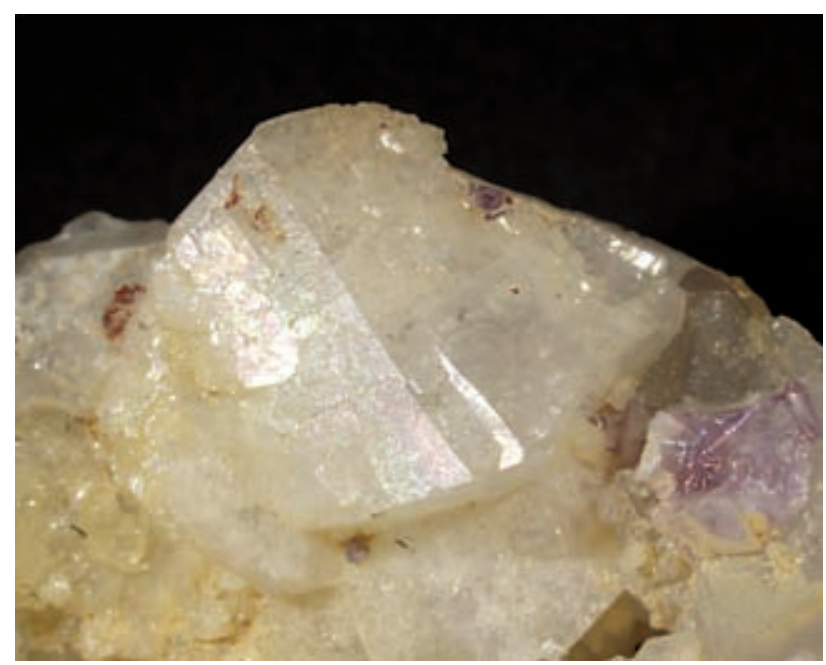

Fig. 40 Translucent fluellite crystals near $1 \mathrm{~cm}$ in size in cavity of coarse-grained quartz, Huber open pit, Krásno. Nicon SMZ1500 microphotography by J.\&E. Sejkora.

siderite, kolbeckite, minerals of the turquoise group, and UNK1, UNK3, UNK4, UNK6, UNK7, UNK8 (Sejkora et al. 2006) occur in close association with fluorapatite III.

d) Fluorapatite IV occurs in cavities of quartz gangue, without apparent relation to phosphate accumulations. It forms irregular crystalline aggregates or minute acicular to columnar crystals, sometimes grouped in radiating ag- gregates. It is colourless, white, grey, yellowish, pink or light violet and is associated with goyazite, crandallite, pharmacosiderite, cassiterite, wolframite, fluorite and clay minerals. Old historical finds of well-crystallized fluorapatite specimens showing variety of colours and crystal morphology (Beran 1999), probably belong to this type of occurrence.

All the described fluorapatite types were confirmed by $\mathrm{X}$-ray powder diffraction, in more than 70 individual samples. Minor deviations from ideal fluorapatite diffraction patterns are probably caused by elevated contents of $\mathrm{Mn} \mathrm{a} \mathrm{Fe}$ in the particular samples.

The general formula of fluorapatite can be presented as $\mathrm{A}_{5}\left(\mathrm{TO}_{4}\right)_{3} \mathrm{Z}$, with $A$-site dominanted by $\mathrm{Ca}$, and variable quantities of $\mathrm{Mn}, \mathrm{Fe}, \mathrm{Sr}, \mathrm{REE}, \mathrm{Pb}$, Na etc. (Leroy Bres 2001; Chen et al. 2002; Hughes et al. 2004). The tetrahedral $T$-site contains $\mathrm{P}$ as strongly dominating elements besides As, V, C, Si, S, $\mathrm{Mn}^{5+}$ and $\mathrm{Cr}^{5+}$ (Hughes et al. 2004). In the $Z$-site, the fluorine content must be higher than $(\mathrm{OH})$ or $\mathrm{Cl}$ (hydroxylapatite and chlorapatite).

Fluorapatites of all the morphological (or genetic) types from the Huber open pit, from the $5^{\text {th }}$ level of the Huber shaft and from samples probably coming from the Gellnauer vein system have been studied by electron microprobe (Table 14). It is interesting that chemical composition in all studied samples shows small variation, irrespective of their morphological or genetic type or actual

Table 11 X-ray powder diffraction data of fluellite

\begin{tabular}{|c|c|c|c|c|c|c|c|c|c|c|c|c|c|c|}
\hline$I_{r e l}$ & $d$ & $h$ & $k$ & $l$ & $I_{r e l}$ & $d$ & $h$ & $k$ & $l$ & $I_{r e l}$ & $d$ & $h$ & $k$ & $l$ \\
\hline 100 & 6.491 & 1 & 1 & 1 & 5 & 2.3162 & 3 & 1 & 5 & 7 & 1.6985 & 2 & 6 & 2 \\
\hline 3 & 5.290 & 0 & 0 & 4 & 5 & 2.2978 & 2 & 4 & 2 & 3 & 1.6863 & 5 & 1 & 1 \\
\hline 9 & 4.982 & 0 & 2 & 2 & 12 & 2.2590 & 3 & 3 & 1 & 7 & 1.6820 & 4 & 4 & 2 \\
\hline 1 & 4.910 & 1 & 1 & 3 & 26 & 2.1637 & 3 & 3 & 3 & 5 & 1.6585 & 0 & 6 & 6 \\
\hline 8 & 3.964 & 2 & 0 & 2 & 7 & 2.1505 & 2 & 4 & 4 & 7 & 1.6327 & 3 & 5 & 5 \\
\hline 6 & 3.409 & 2 & 2 & 0 & 13 & 2.1403 & 4 & 0 & 0 & 6 & 1.5715 & 5 & 1 & 5 \\
\hline 43 & 3.244 & 2 & 2 & 2 & 6 & 2.0414 & 3 & 1 & 7 & 4 & 1.5673 & 2 & 2 & 12 \\
\hline 18 & 3.094 & 1 & 3 & 3 & 5 & 1.9833 & 0 & 2 & 10 & 5 & 1.5462 & 2 & 6 & 6 \\
\hline 8 & 2.991 & 0 & 2 & 6 & 7 & 1.9579 & 2 & 4 & 6 & 7 & 1.5271 & 3 & 5 & 7 \\
\hline 11 & 2.867 & 2 & 2 & 4 & 2 & 1.9437 & 1 & 3 & 9 & 5 & 1.4964 & 0 & 4 & 12 \\
\hline 11 & 2.766 & 1 & 1 & 7 & 7 & 1.9391 & 1 & 5 & 5 & 5 & 1.4724 & 1 & 3 & 13 \\
\hline 17 & 2.743 & 3 & 1 & 1 & 6 & 1.8167 & 3 & 3 & 7 & 6 & 1.4331 & 4 & 4 & 8 \\
\hline 3 & 2.728 & 2 & 0 & 6 & 8 & 1.7987 & 2 & 2 & 10 & 6 & 1.3847 & 5 & 3 & 7 \\
\hline 15 & 2.670 & 1 & 3 & 5 & 7 & 1.7636 & 0 & 0 & 12 & 6 & 1.3720 & 6 & 2 & 2 \\
\hline 2 & 2.648 & 0 & 0 & 8 & 4 & 1.7611 & 3 & 5 & 1 & 9 & 1.3608 & 4 & 0 & 12 \\
\hline 6 & 2.489 & 0 & 4 & 4 & 5 & 1.7407 & 4 & 2 & 6 & & & & & \\
\hline 10 & 2.452 & 2 & 2 & 6 & 11 & 1.7040 & 4 & 4 & 0 & & & & & \\
\hline
\end{tabular}

Table 13 Chemical composition of fluellite (in wt. \%)

Table 12 Unit-cell parameters of fluellite (for orthorhombic space group Fddd)

\begin{tabular}{|lcccc|}
\hline & $\begin{array}{c}\text { Krásno } \\
\text { this paper }\end{array}$ & $\begin{array}{c}\text { Cornwall } \\
\text { Guy }\end{array}$ & $\begin{array}{c}\text { Cornwall } \\
\text { Jeffrey (1966) }\end{array}$ & $\begin{array}{c}\text { ACDD } 1 \text { 19-0038 } \\
\text { ICDD 37-0450 }\end{array}$ \\
\hline $\mathrm{a}[\AA]$ & $8.558(1)$ & $8.546(8)$ & 8.546 & $8.5726(8)$ \\
$\mathrm{b}[\AA]$ & $11.274(1)$ & $11.222(5)$ & 11.259 & $11.255(1)$ \\
$\mathrm{c}[\AA]$ & $21.179(2)$ & $21.158(5)$ & 21.151 & $21.186(2)$ \\
$\mathrm{V}\left[\AA^{3}\right]$ & $2043.5(3)$ & 2029.12 & 2035.1 & 2044.1 \\
\hline
\end{tabular}

\begin{tabular}{|l|ccc|}
\hline & mean & range (4 analyses) & ideal \\
\hline $\mathrm{Al}_{2} \mathrm{O}_{3}$ & 36.40 & $36.06-36.98$ & 30.89 \\
$\mathrm{P}_{2} \mathrm{O}_{5}$ & 27.29 & $26.93-27.74$ & 21.51 \\
$\mathrm{~F}$ & 13.65 & $13.37-13.96$ & 11.51 \\
$\mathrm{H}_{2} \mathrm{O}$ & 47.95 & & 40.95 \\
$-\mathrm{F}=\mathrm{O}$ & 5.75 & & 4.86 \\
total & 119.54 & & 100.00 \\
\hline
\end{tabular}

Additional elements were analyzed, including $\mathrm{Na}, \mathrm{K}, \mathrm{Mn}, \mathrm{Sr}$, $\mathrm{Ca}, \mathrm{Ba}, \mathrm{Cu}, \mathrm{Zn}, \mathrm{Fe}, \mathrm{Bi}, \mathrm{Si}, \mathrm{As}, \mathrm{S}$ a Cl ; the analysis confirmed their absence or abundances below detection limit of c. 0.010.05 wt. $\%$. 
Table 14 Chemical composition of fluorapatite (in wt. \%)

\begin{tabular}{|c|c|c|c|c|c|c|c|c|c|c|c|c|}
\hline & $\mathrm{M}$ & $\mathrm{M}$ & $\mathrm{M}$ & $\mathrm{M}$ & M & $\mathrm{O}$ & $\mathrm{O}$ & $\mathrm{O}$ & $\mathrm{O}$ & $\mathrm{O}$ & $\mathrm{G}$ & $\mathrm{G}$ \\
\hline $\mathrm{Na}_{2} \mathrm{O}$ & 0.05 & 0.34 & 0.18 & 0.23 & 0.06 & 0.27 & 0.23 & 0.00 & 0.21 & 0.29 & 0.34 & 0.08 \\
\hline $\mathrm{K}_{2} \mathrm{O}$ & 0.00 & 0.00 & 0.00 & 0.00 & 0.00 & 0.00 & 0.00 & 0.00 & 0.03 & 0.03 & 0.00 & 0.00 \\
\hline $\mathrm{PbO}$ & 0.00 & 0.00 & 0.00 & 0.00 & 0.05 & 0.00 & 0.02 & 0.00 & 0.00 & 0.00 & 0.10 & 0.00 \\
\hline $\mathrm{CuO}$ & 0.00 & 0.00 & 0.00 & 0.00 & 0.00 & 0.00 & 0.00 & 0.00 & 0.00 & 0.24 & 0.22 & 0.00 \\
\hline $\mathrm{ZnO}$ & 0.00 & 0.00 & 0.10 & 0.00 & 0.00 & 0.00 & 0.14 & 0.00 & 0.03 & 0.08 & 0.13 & 0.00 \\
\hline $\mathrm{FeO}$ & 1.49 & 0.06 & 1.02 & 2.13 & 0.57 & 2.49 & 1.34 & 0.11 & 1.77 & 4.09 & 2.52 & 0.67 \\
\hline $\mathrm{MnO}$ & 4.06 & 0.20 & 2.93 & 4.76 & 2.56 & 3.90 & 2.55 & 0.51 & 3.72 & 3.15 & 3.59 & 2.12 \\
\hline $\mathrm{BaO}$ & 0.00 & 0.00 & 0.00 & 0.01 & 0.26 & 0.00 & 0.04 & 0.00 & 0.06 & 0.13 & 0.19 & 0.00 \\
\hline $\mathrm{SrO}$ & 0.00 & 0.09 & 0.22 & 0.63 & 0.07 & 0.50 & 0.16 & 0.02 & 0.59 & 0.29 & 0.45 & 0.00 \\
\hline $\mathrm{CaO}$ & 51.40 & 55.87 & 51.84 & 49.42 & 51.99 & 48.36 & 49.81 & 55.00 & 49.52 & 46.26 & 49.02 & 52.84 \\
\hline $\mathrm{MgO}$ & 0.00 & 0.00 & 0.05 & 0.04 & 0.01 & 0.09 & 0.30 & 0.02 & 0.05 & 0.05 & 0.02 & 0.00 \\
\hline $\mathrm{Al}_{2} \mathrm{O}_{3}$ & 0.25 & 0.00 & 0.01 & 0.00 & 0.00 & 0.00 & 0.97 & 0.00 & 0.01 & 0.04 & 0.01 & 0.00 \\
\hline $\mathrm{TiO}_{2}$ & 0.00 & 0.00 & 0.01 & 0.01 & 0.00 & 0.00 & 0.18 & 0.04 & 0.00 & 0.02 & 0.28 & 0.00 \\
\hline $\mathrm{SiO}_{2}$ & 0.00 & 0.00 & 0.00 & 0.00 & 0.00 & 0.00 & 0.03 & 0.00 & 0.01 & 0.08 & 0.02 & 0.00 \\
\hline $\mathrm{P}_{2} \mathrm{O}_{5}$ & 41.51 & 41.54 & 41.79 & 40.82 & 42.93 & 40.49 & 40.63 & 43.12 & 41.32 & 37.48 & 39.50 & 42.00 \\
\hline $\mathrm{As}_{2} \mathrm{O}_{5}$ & 0.00 & 0.00 & 0.00 & 0.00 & 0.00 & 0.00 & 0.00 & 0.00 & 0.00 & 0.00 & 0.00 & 0.00 \\
\hline $\mathrm{SO}_{3}$ & 0.03 & 1.01 & 0.16 & 0.26 & 0.00 & 0.45 & 0.05 & 0.04 & 0.36 & 0.53 & 0.15 & 0.04 \\
\hline $\mathrm{Cl}^{3}$ & 0.00 & 0.03 & 0.51 & 1.11 & 0.01 & 1.22 & 0.00 & 0.08 & 0.88 & 0.89 & 0.68 & 0.00 \\
\hline $\mathrm{F}$ & 3.71 & 3.05 & 3.65 & 2.51 & 3.44 & 2.62 & 3.26 & 3.68 & 3.13 & 3.09 & 3.29 & 3.37 \\
\hline$-\mathrm{O}=\mathrm{Cl}$ & 0.00 & -0.01 & -0.12 & -0.25 & 0.00 & -0.28 & -0.15 & -0.02 & -0.20 & -0.20 & -0.15 & 0.00 \\
\hline$-\mathrm{O}=\mathrm{F}$ & -1.56 & -1.28 & -1.54 & -1.06 & -1.45 & -1.10 & -1.37 & -1.55 & -1.32 & -1.30 & -1.39 & -1.42 \\
\hline$* \mathrm{H}_{2} \mathrm{O}$ & 0.99 & 1.27 & 0.00 & 1.50 & 0.00 & 0.57 & 0.29 & 0.00 & 0.00 & 1.85 & 1.77 & 0.22 \\
\hline total & 101.93 & 102.17 & 100.811 & 102.131 & 100.49 & 99.58 & 98.48 & 101.051 & 100.16 & 97.09 & 100.74 & 99.92 \\
\hline$S^{6+}$ & 0.002 & 0.064 & $4 \quad 0.010$ & 0.017 & 0.000 & 0.029 & 0.020 & 0.002 & 0.023 & 0.037 & 0.010 & 0.002 \\
\hline $\mathrm{P}^{5+}$ & 2.998 & 2.936 & 2.990 & 2.983 & 3.000 & 2.971 & 2.980 & 2.998 & 2.976 & 2.956 & 2.988 & 2.998 \\
\hline $\mathrm{As}^{5+}$ & 0.000 & 0.000 & 0.000 & 0.000 & 0.000 & 0.000 & 0.000 & 0.000 & 0.000 & 0.000 & 0.000 & 0.000 \\
\hline $\mathrm{Si}^{4+}$ & 0.000 & 0.000 & 0.000 & 0.000 & 0.000 & 0.000 & 0.000 & 0.000 & 0.001 & 0.007 & 0.002 & 0.000 \\
\hline subtot & 3.000 & 3.000 & 3.000 & 3.000 & 3.000 & 3.000 & 3.000 & 3.000 & 3.000 & 3.000 & 3.000 & 3.000 \\
\hline $\mathrm{Ti}^{4+}$ & 0.000 & 0.000 & 0.001 & 0.001 & 0.000 & 0.000 & 0.000 & 0.002 & 0.000 & 0.001 & 0.018 & 0.000 \\
\hline $\mathrm{Al}^{3+}$ & 0.025 & 0.000 & 0.001 & 0.000 & 0.000 & 0.000 & 0.002 & 0.000 & 0.001 & 0.004 & 0.001 & 0.000 \\
\hline $\mathrm{Pb}^{2+}$ & 0.000 & 0.000 & 0.000 & 0.000 & 0.001 & 0.000 & 0.000 & 0.000 & 0.000 & 0.000 & 0.002 & 0.000 \\
\hline $\mathrm{Cu}^{2+}$ & 0.000 & 0.000 & 0.000 & 0.000 & 0.000 & 0.000 & 0.000 & 0.000 & 0.000 & 0.017 & 0.015 & 0.000 \\
\hline $\mathrm{Zn}^{2+}$ & 0.000 & 0.000 & 0.006 & 0.000 & 0.000 & 0.000 & 0.001 & 0.000 & 0.002 & 0.005 & 0.009 & 0.000 \\
\hline $\mathrm{Fe}^{2+}$ & 0.106 & 0.004 & 0.072 & 0.154 & 0.039 & 0.181 & 0.096 & 0.008 & 0.126 & 0.319 & 0.189 & 0.047 \\
\hline $\mathrm{Mn}^{2+\cdot \cdot}$ & 0.294 & 0.014 & 0.209 & 0.348 & 0.179 & 0.286 & 0.232 & 0.035 & 0.268 & 0.248 & 0.271 & 0.151 \\
\hline $\mathrm{Ba}^{2+}$ & 0.000 & 0.000 & 0.000 & 0.000 & 0.008 & 0.000 & 0.003 & 0.000 & 0.002 & 0.005 & 0.007 & 0.000 \\
\hline $\mathrm{Sr}^{2+}$ & 0.000 & 0.004 & 0.011 & 0.031 & 0.003 & 0.025 & 0.020 & 0.001 & 0.029 & 0.016 & 0.023 & 0.000 \\
\hline $\mathrm{Ca}^{2+}$ & 4.698 & 4.999 & 4.695 & 4.571 & 4.599 & 4.490 & 4.643 & 4.840 & 4.513 & 4.618 & 4.692 & 4.773 \\
\hline $\mathrm{Mg}^{2+}$ & 0.000 & 0.000 & 0.006 & 0.005 & 0.002 & 0.011 & 0.006 & 0.002 & 0.006 & 0.007 & 0.003 & 0.000 \\
\hline $\mathrm{Na}^{+}$ & 0.008 & 0.056 & 0.029 & 0.038 & 0.009 & 0.045 & 0.038 & 0.000 & 0.034 & 0.053 & 0.059 & 0.013 \\
\hline $\mathrm{K}^{+}$ & 0.000 & 0.000 & 0.000 & 0.000 & 0.000 & 0.000 & 0.001 & 0.000 & 0.003 & 0.004 & 0.000 & 0.000 \\
\hline subtot & 5.131 & 5.077 & 5.031 & 5.148 & 4.841 & 5.039 & 5.043 & 4.888 & 4.984 & 5.297 & 5.290 & 4.985 \\
\hline $\mathrm{Cl}^{-}$ & 0.001 & 0.004 & 0.073 & 0.163 & 0.001 & 0.179 & 0.100 & 0.011 & 0.126 & 0.141 & 0.104 & 0.001 \\
\hline $\mathrm{F}^{-}$ & 1.002 & 0.805 & 0.975 & 0.686 & 0.897 & 0.718 & 0.889 & 0.956 & 0.842 & 0.911 & 0.930 & 0.897 \\
\hline$* \mathrm{OH}^{-}$ & 0.278 & 0.353 & 0.000 & 0.429 & 0.000 & 0.163 & 0.084 & 0.000 & 0.000 & 0.523 & 0.534 & 0.061 \\
\hline subtot & 1.281 & 1.162 & 1.049 & 1.278 & 0.898 & 1.061 & 1.073 & 0.967 & 0.968 & 1.574 & 1.567 & 0.958 \\
\hline
\end{tabular}

$\mathrm{O}-$ Huber open pit; $\mathrm{M}-5^{\text {th }}$ level of the Huber shaft; $\mathrm{G}-$ Gellnauer vein system.

Empirical formulas were calculated on the basis of $(\mathrm{P}+\mathrm{As}+\mathrm{S}+\mathrm{Si})=3$ and charge balance; water content is calculated from charge balance.

location. On the other hand, compositional variation in one type of fluorapatite from a single location may exceed differences among fluorapatite samples from other localities.

The $A$-site in fluorapatite from Krásno contains, in addition to dominating $\mathrm{Ca}$, only $\mathrm{Mn}$ and $\mathrm{Fe}$ as important elements entering via homeovalent substitution $(\mathrm{Mn}, \mathrm{Fe}) \mathrm{Ca}_{-1}$. Manganese shows the range of 0-0.39 apfu. The iron content is almost always lower than Mn content (Fig. 41), but it is rather high (up to 0.32 apfu) in comparison with fluorapatites from pegmatites and granitic rocks (Moore 1982). Similar Fe contents in apatite were observed from beryl-columbite-phosphate pegmatite in Olary Block,
Australia (up to 0.33 apfu), where apatite is associated with triplite (Lottermoser - Lu 1997). Sr contents do not exceed $0.05 \mathrm{apfu}$. The total of $\mathrm{Mn}+\mathrm{Fe}+\mathrm{Sr}$ in part of specimens correlates with $\mathrm{Cl}$ content (Fig. 42). The $T$-site contains only minor As and $\mathrm{Si}$, the content of $\mathrm{S}$ is in the range of 0 to 0.03 (a singular case with 0.07) apfu in addition to dominating P. Regarding the $Z$-site occupancy, all studied samples belong to fluorapatite (Fig. 43); F always dominates over $\mathrm{Cl}$ and the content of $(\mathrm{OH})$ was calculated by stoichiometry. Empirical formulas calculated on the basis of $(\mathrm{P}+\mathrm{As}+\mathrm{S}+\mathrm{Si})=3$, corresponding to selected spot analyses of fluorapatite from Krásno, are given in Table 14. 


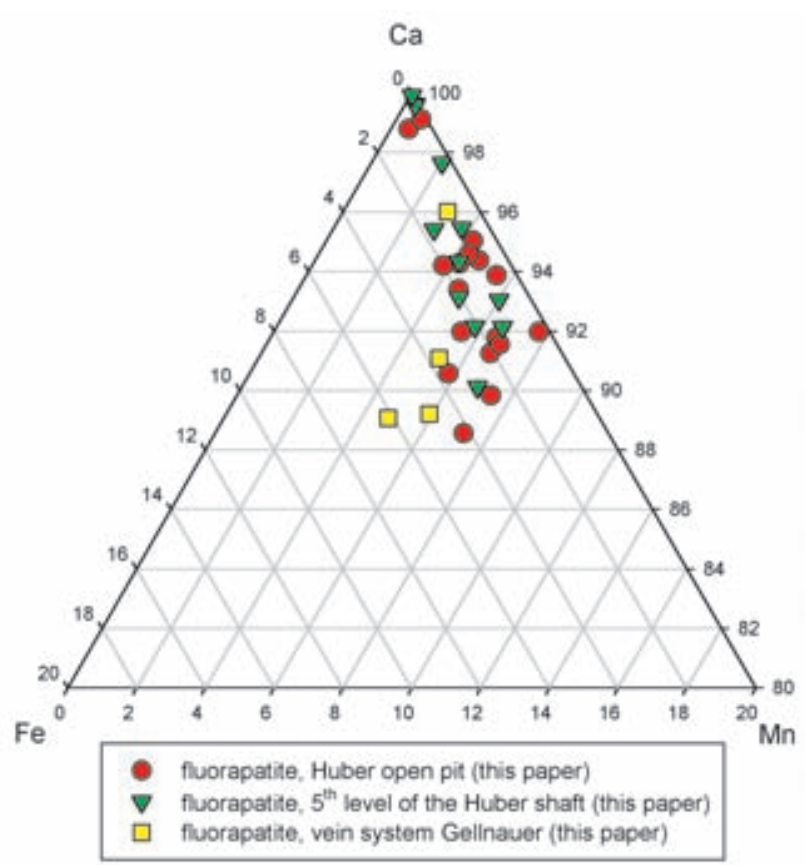

Fig. 41 Part of ternary plot of $A$-site occupancy (atomic ratio) in fluorapatite from Krásno.

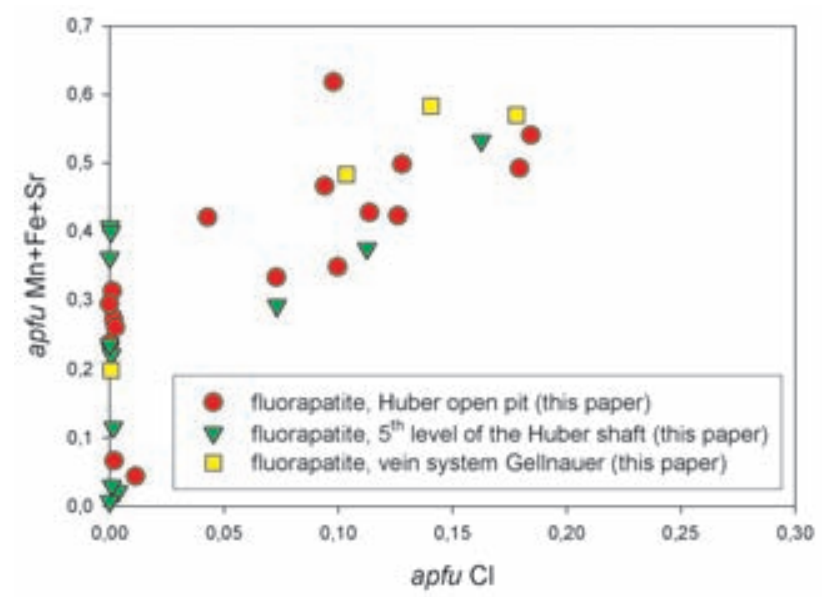

Fig. 42 A plot of apfu $\mathrm{Cl}$ vs. $(\mathrm{Mn}+\mathrm{Fe}+\mathrm{Sr})$ in fluorapatite from Krásno.

Minerals of the frondelite - rockbridgeite series
$\mathrm{Mn}^{2+} \mathrm{Fe}^{3+}{ }_{4}\left(\mathrm{PO}_{4}\right)_{3}(\mathrm{OH})_{5}-\mathrm{Fe}^{2+} \mathrm{Fe}^{3+}{ }_{4}(\mathrm{PO})_{3}(\mathrm{OH})_{5}$

Minerals of the frondelite - rockbridgeite series were encountered during the present study only in samples from phosphate accumulation at the $5^{\text {th }}$ level of the $\mathrm{Hu}-$ ber shaft. Identification of rare rockbridgeite from more abundant frondelite is possible only by quantitative study of chemical composition.

Rockbridgeite occurs as fine-grained to compact aggregates, up to several $\mathrm{cm}$ across, composed of tiny equant grains less than $0.1 \mathrm{~mm}$. The aggregates have dark black-green or black colour with a dark green streak. This mineral replaced older reddish brown fluorapatite and probably also triplite (however, their contacts were rare-

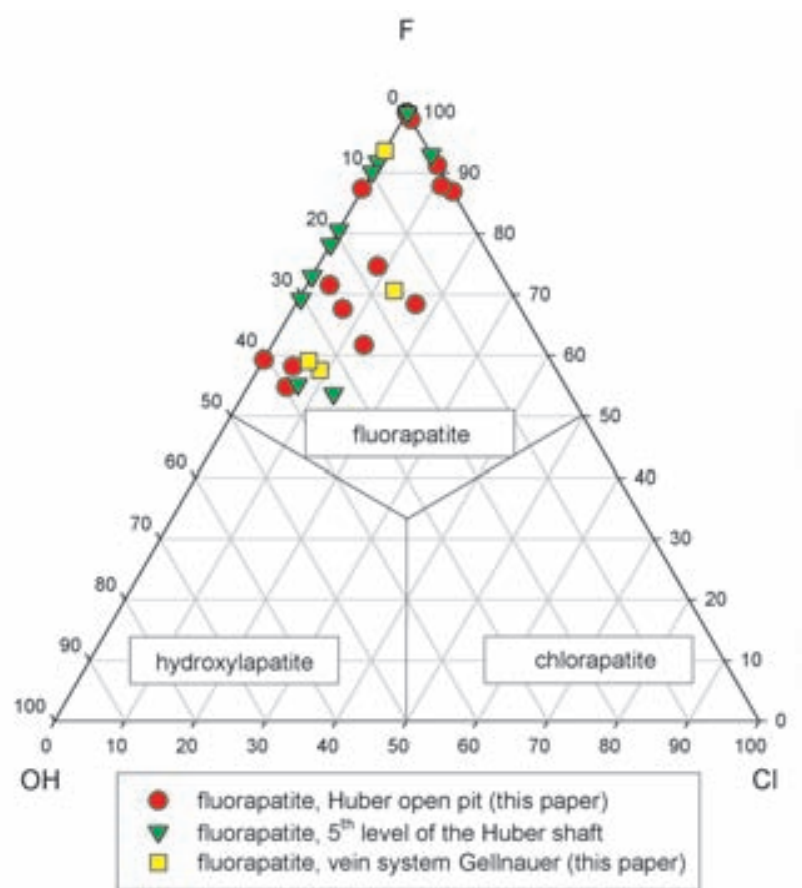

Fig. 43 Ternary plot of $Z$-site occupancy (F-Cl-OH by difference) in fluorapatite from Krásno.

ly observed) and it is intensively replaced by younger beraunite, UNK9 and partly by the youngest light blue phosphosiderite and Mn oxides. In triplite and rockbridgeite aggregates, younger phosphosiderite preferentially replaced triplite (Fig. 44). Also observed was white, fine-grained to compact fluorapatite IV, as one of the youngest minerals in this association.

Frondelite forms up to $15 \mathrm{~cm}$ long aggregates replacing older triplite and reddish-brown fluorapatite (partly replaced by younger isokite). Frondelite occurs in two distinct varieties showing differences in morfology and colour. The older frondelite I forms crystalline aggregates of dark black-green or black colour and dark green streak,

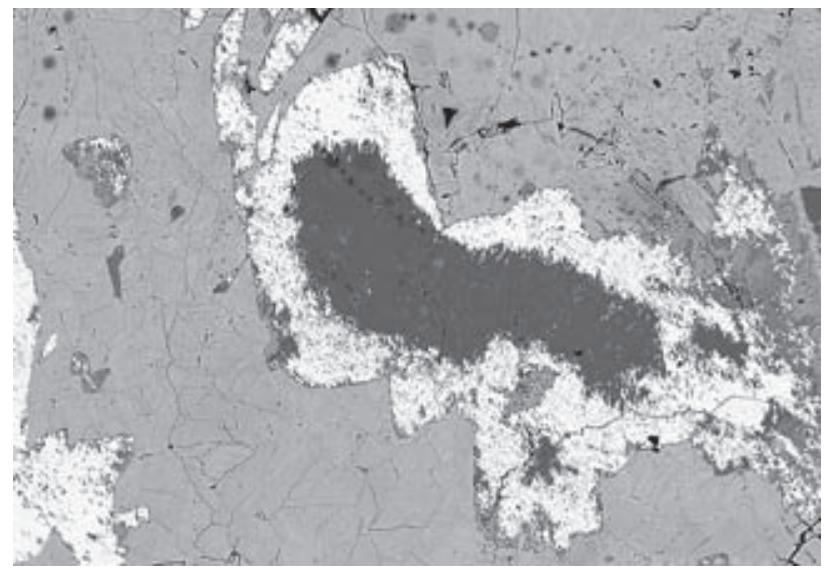

Fig. 44 Rockbridgeite (grey groundmass) with triplite relics (light) intensively replaced by phosphosiderite (dark). $5^{\text {th }}$ level of the Huber shaft, Krásno. Width of photo $1200 \mu \mathrm{m}$. Cameca SX100, BSE photograph by J. Sejkora and R. Škoda. 
with grain-size less than $0.1 \mathrm{~mm}$ (Fig. 45). Small cavities, $2-3 \mathrm{~mm}$ in size, rarely contain black minute, highly lustrous prismatic crystals $0.1 \mathrm{~mm}$ in size (Fig. 46). The younger type of frondelite II has been found as finegrained radiating aggregates, up to $1 \mathrm{~cm}$ in diameter, redbrown to brown in colour (Fig. 47). Some of the aggregates show colour zoning in various shades of brown. The younger frondelite II is usually deposited directly on the older green type I; in some cases, there are aggregates of UNK9 at the boundary of the two types. Both types of frondelite were replaced by beraunite and later on, all these minerals by the youngest phosphosiderite (Fig. 48). Morinite and purple-coloured strengite are closely associated.

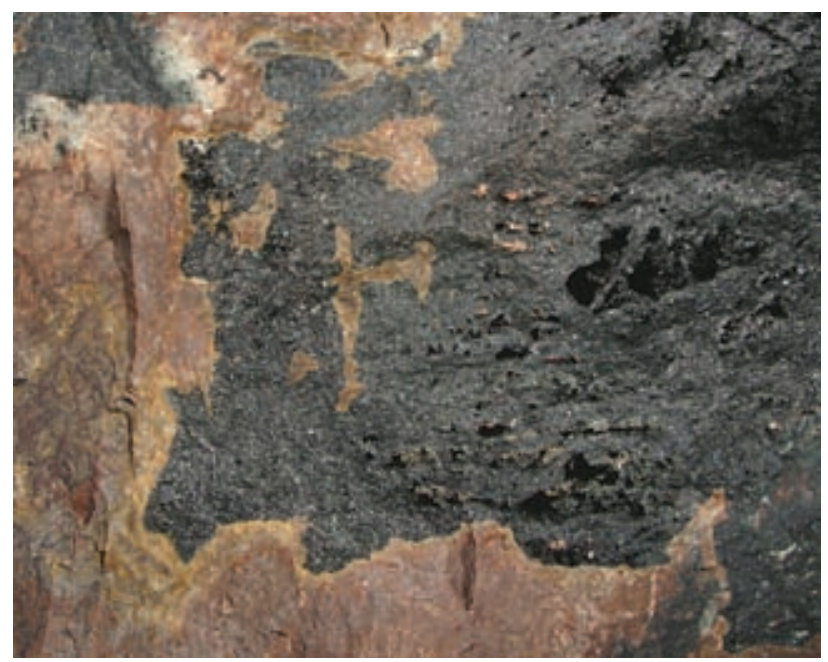

Fig. 45 Black frondelite I aggregates in compact mass of fluorapatite partly replaced by isokite. $5^{\text {th }}$ level of the Huber shaft, Krásno. Width of $31 \mathrm{~mm}$. Nicon SMZ1500 microphotography by J. \& E. Sejkora.

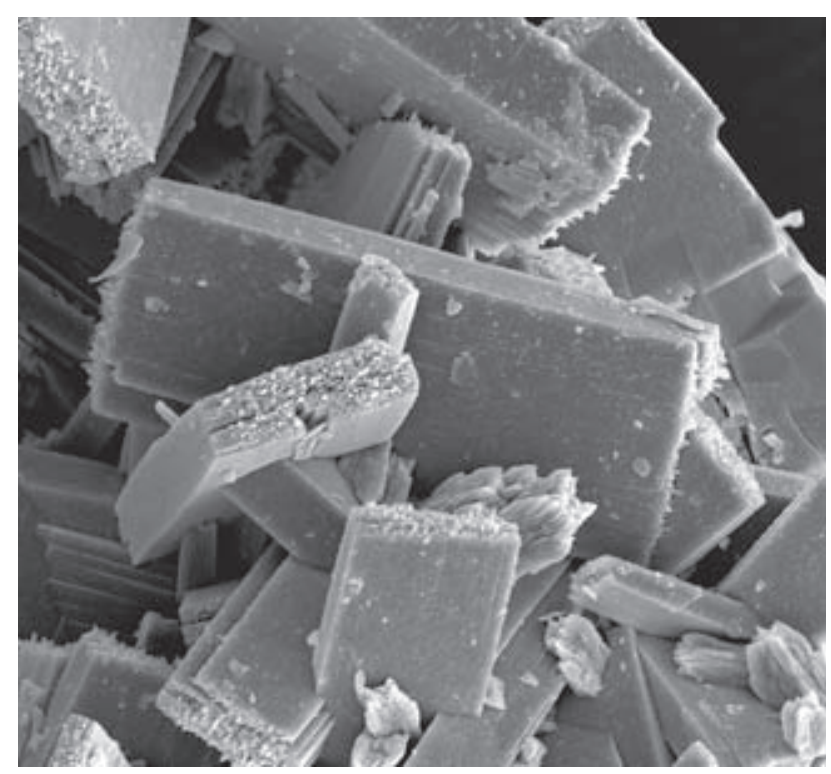

Fig. 46 Prismatic crystals of frondelite I. $5^{\text {th }}$ level of the Huber shaft, Krásno. Width of $60 \mu \mathrm{m}$. SEM photograph by J. Sejkora and J. Plášil.

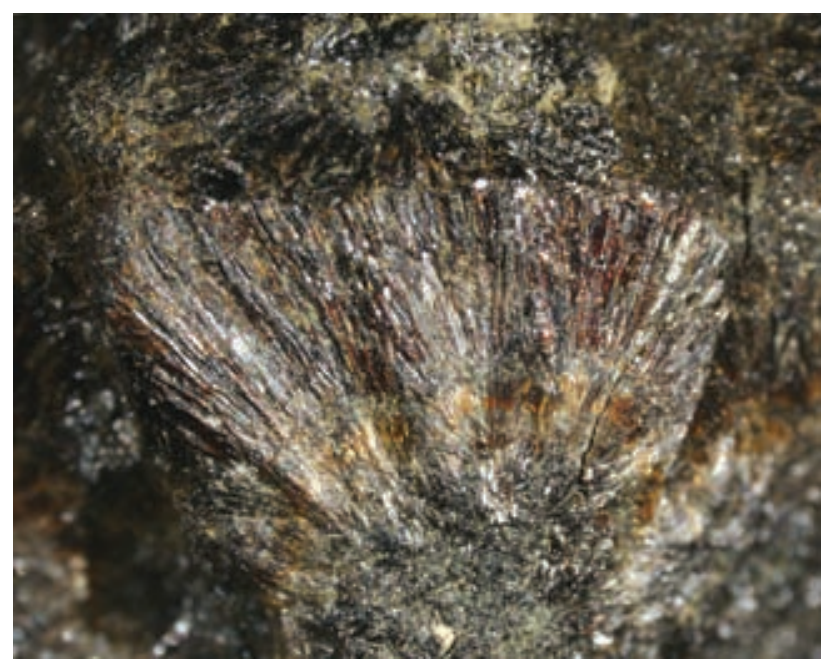

Fig. 47 Radiating aggregates of younger frondelite II. $5^{\text {th }}$ level of the Huber shaft, Krásno. Width of $6 \mathrm{~mm}$. Nicon SMZ1500 microphotography by J. \& E. Sejkora.

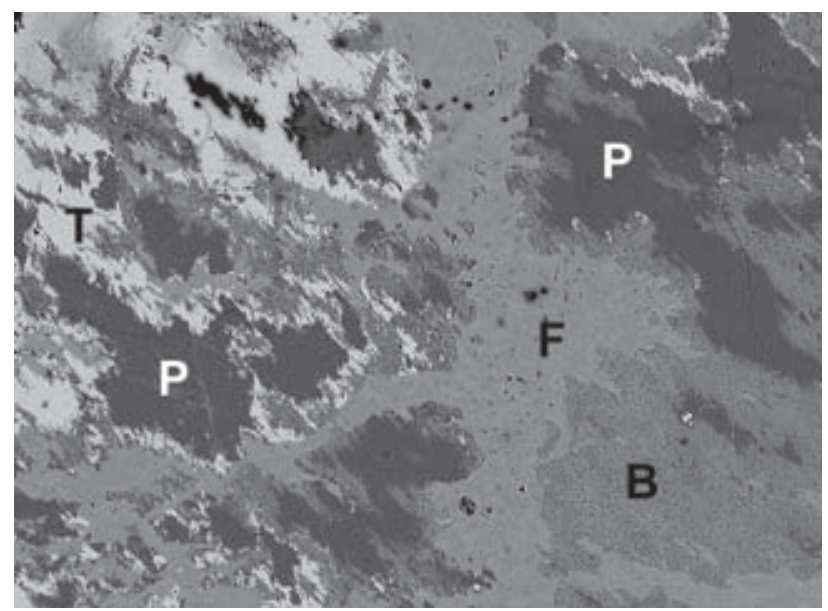

Fig. 48 Agregates of frondelite $(\mathrm{F})$ and triplite $(\mathrm{T})$; beraunite (B) replaces frondelite; in the same sample beraunite and triplite are replaced by younger phosphosiderite (P). $5^{\text {th }}$ level of the Huber shaft, Krásno. Width of photo $1000 \mu \mathrm{m}$. Cameca SX100, BSE photograph by J. Sejkora and R. Škoda.

It is not possible to identify rockbridgeite from frondelite on the basis of X-ray diffraction data, as can be seen from diffraction patterns of over 15 samples of chemically defined material. The variation observed in one species exceeds differences between the two species (Table 15). The refined unit-cell parameters (Table 16) correspond to the published data for minerals of rockbridgeite - frondelite series.

The chemical composition of minerals of the rockbridgeite - frondelite series can be expressed by the general formula $\mathrm{AB}_{4}\left(\mathrm{TO}_{4}\right)_{3}(\mathrm{OH})_{5}$. In order to simplify calculation, it is assumed that the $A$-site is filled by $\mathrm{Mn}$ (exclusively as $\mathrm{Mn}^{2+}$ ), $\mathrm{Zn}^{2+}$ and other $\mathrm{M}^{+}$and $\mathrm{M}^{2+}$ cations. The $\mathrm{Fe}^{2+}$ content is derived from filling the $A$-site to ideal $\mathrm{A}=1$. The remaining $\mathrm{Fe}\left(\right.$ as $\mathrm{Fe}^{3+}$ ), $\mathrm{Al}^{3+}$ and $\mathrm{Ti}^{4+}$ fill the $B$-site. It should be noted that Lindberg (1949) and 
Moore (1970) include in $A$-site also $\mathrm{Fe}^{3+}$ and in $B$-site also $\mathrm{Mn}^{3+}$; Lindberg - Frondel (1950) considered entry of $\mathrm{Zn}^{2+}$ exclusively in $B$-site in $\mathrm{Zn}$-rich rockbridgeite, without any supporting evidence.

The $A$-site occupancy indicates that majority of studied samples from Krásno (Fig. 49) corresponds to fron-

Table 15 X-ray powder diffraction data of minerals in the series rockbridgeite - frondelite.

\begin{tabular}{|c|c|c|c|c|c|c|c|c|}
\hline \multicolumn{2}{|c|}{ sample A } & \multicolumn{2}{|c|}{ sample B } & \multicolumn{2}{|c|}{ sample C } & \multirow[b]{2}{*}{$h$} & \multirow[b]{2}{*}{$k$} & \multirow[b]{2}{*}{$l$} \\
\hline$I_{r e l}$ & $d$ & $I_{r e l}$ & $d$ & $I_{r e l}$ & $d$ & & & \\
\hline 64 & 6.913 & 61 & 6.967 & 63 & 6.929 & 0 & 2 & 0 \\
\hline 17 & 4.840 & 15 & 4.846 & 27 & 4.842 & 1 & 1 & 0 \\
\hline 18 & 4.623 & 12 & 4.658 & 25 & 4.652 & 1 & 1 & 1 \\
\hline 21 & 4.367 & 11 & 4.366 & 30 & 4.366 & 0 & 2 & 3 \\
\hline 31 & 4.208 & 15 & 4.209 & 41 & 4.221 & 0 & 0 & 4 \\
\hline 33 & 3.665 & 21 & 3.673 & 37 & 3.665 & 1 & 1 & 3 \\
\hline 53 & 3.595 & 41 & 3.602 & 71 & 3.605 & 0 & 2 & 4 \\
\hline 51 & 3.447 & 49 & 3.456 & 50 & 3.444 & 1 & 3 & 0 \\
\hline \multirow[t]{2}{*}{83} & 3.386 & 100 & 3.413 & 87 & 3.392 & 0 & 4 & 1 \\
\hline & 3.386 & 23 & 3.389 & 29 & 3.377 & 1 & 3 & 1 \\
\hline 100 & 3.184 & 88 & 3.198 & 100 & 3.189 & 1 & 3 & 2 \\
\hline 34 & 3.027 & 33 & 3.030 & 51 & 3.037 & 0 & 2 & 5 \\
\hline 26 & 2.957 & 22 & 2.964 & 31 & 2.960 & 0 & 4 & 3 \\
\hline 38 & 2.798 & 23 & 2.805 & 35 & 2.817 & 0 & 0 & 6 \\
\hline \multirow[t]{2}{*}{41} & 2.763 & 31 & 2.763 & 42 & 2.770 & 1 & 1 & 5 \\
\hline & 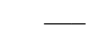 & 22 & 2.683 & 34 & 2.677 & 0 & 4 & 4 \\
\hline 29 & 2.588 & 19 & 2.589 & 33 & 2.583 & 2 & 0 & 0 \\
\hline \multirow[t]{2}{*}{37} & 2.4269 & 47 & 2.4259 & 54 & 2.4319 & 1 & 1 & 6 \\
\hline & 2.4269 & & 2.4259 & 33 & 2.4178 & 1 & 5 & 1 \\
\hline 29 & 2.4083 & 31 & 2.4101 & 61 & 2.4117 & 1 & 3 & 5 \\
\hline 23 & 2.2720 & 17 & 2.2671 & 38 & 2.2781 & 0 & 2 & 7 \\
\hline 21 & 2.1759 & 17 & 2.1783 & 29 & 2.1804 & 1 & 3 & 6 \\
\hline \multirow[t]{2}{*}{20} & 2.1537 & 20 & 2.1529 & 37 & 2.1601 & 1 & 1 & 7 \\
\hline & - & 19 & 2.1180 & 38 & 2.1127 & 1 & 5 & 4 \\
\hline 23 & 2.0601 & 17 & 2.0662 & 36 & 2.0575 & 2 & 4 & 1 \\
\hline 21 & 2.0227 & 20 & 2.0340 & 35 & 2.0257 & 0 & 6 & 4 \\
\hline 31 & 1.9647 & 21 & 1.9681 & 33 & 1.9678 & 2 & 2 & 5 \\
\hline 16 & 1.8487 & 17 & 1.8599 & 36 & 1.8491 & 1 & 7 & 0 \\
\hline 15 & 1.8308 & 16 & 1.8347 & 34 & 1.8317 & 2 & 2 & 6 \\
\hline 13 & 1.7312 & 9 & 1.7420 & 33 & 1.7329 & 0 & 8 & 0 \\
\hline 19 & 1.7136 & 11 & 1.7143 & 32 & 1.7174 & 1 & 5 & 7 \\
\hline 14 & 1.6933 & 9 & 1.6903 & 19 & 1.6892 & 2 & 6 & 2 \\
\hline 13 & 1.6813 & 7 & 1.6804 & 18 & 1.6866 & 0 & 0 & 10 \\
\hline 21 & 1.6425 & 16 & 1.6464 & 31 & 1.6496 & 0 & 4 & 9 \\
\hline 17 & 1.6055 & 19 & 1.6092 & 33 & 1.6035 & 0 & 8 & 4 \\
\hline 15 & 1.5938 & 17 & 1.5947 & 29 & 1.5976 & 2 & 6 & 4 \\
\hline \multirow[t]{2}{*}{13} & 1.5876 & 11 & 1.5889 & 19 & 1.5912 & 3 & 3 & 2 \\
\hline & 1.5876 & & 1.5889 & & 1.5912 & 2 & 2 & 8 \\
\hline
\end{tabular}

A - Mn-rich rockbridgeite ( $A$-site: $\mathrm{Fe}_{056} \mathrm{Mn}_{038} \mathrm{Zn}_{004} \mathrm{Ca}_{002}$ )

$\mathrm{B}$ - black-green granular frondelite I ( $A$-site: $\left.\mathrm{Mn}_{0.82} \mathrm{Fe}_{0.07} \mathrm{Zn}_{0.07} \mathrm{Ca}_{0.02} \mathrm{Na}_{0.01}\right)$

$\mathrm{C}$ - brown-black frondelite II from radiating aggregate

$\left(A\right.$-site: $\left.\mathrm{Mn}_{0.90} \mathrm{Zn}_{0.07} \mathrm{Ca}_{0.02} \mathrm{Na}_{0.01}\right)$

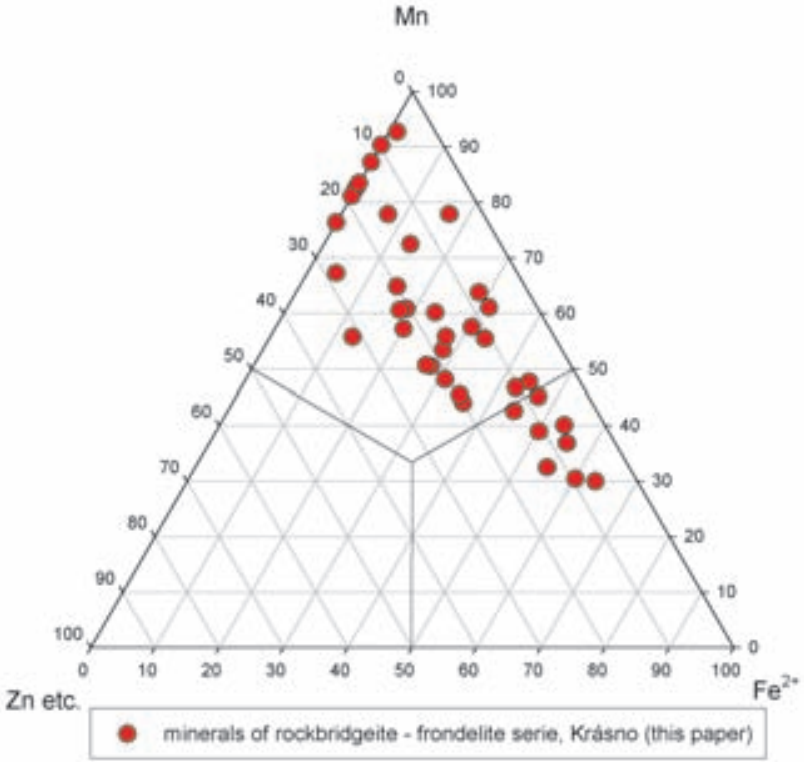

Fig. 49 Ternary plot of $A$-site occupancy (atomic ratio) in minerals of the rockbridgeite - frondelite series from Krásno. Zn etc. = $\mathrm{Zn}+\mathrm{Na}+\mathrm{K}+\mathrm{Ca}+\mathrm{Ba}+\mathrm{Sr}+\mathrm{Mg}+\mathrm{Pb}+\mathrm{Cu}$.

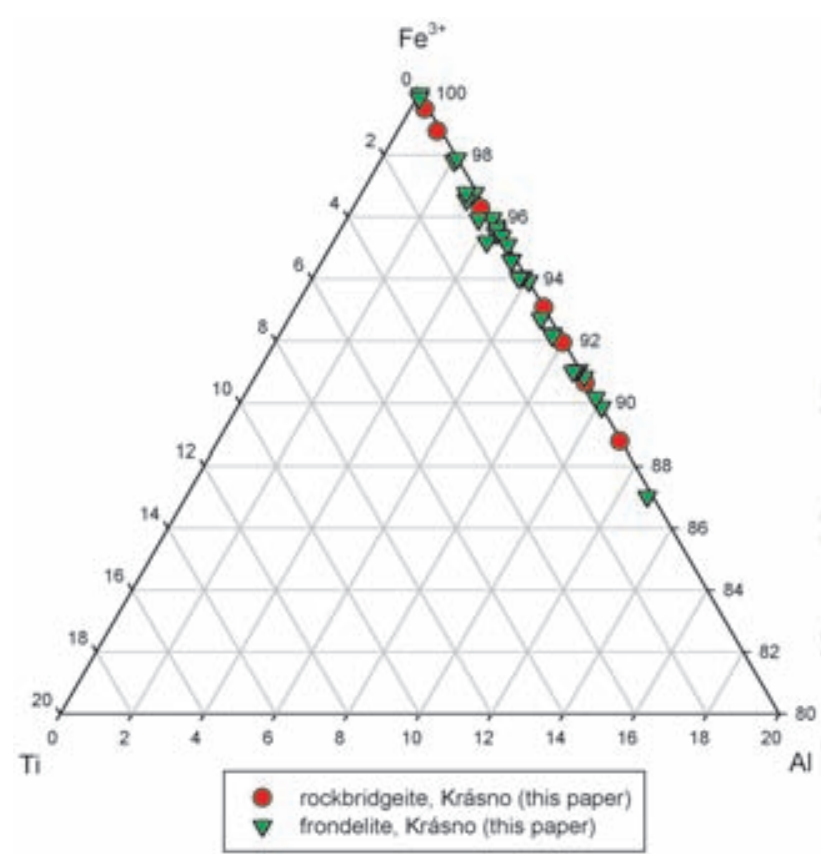

Fig. 50 Part of ternary plot of $B$-site occupancy (atomic ratio) in minerals of the rockbridgeite - frondelite series from Krásno.

Tab le 16 Unit-cell parameters of minerals of the rockbridgeite - frondelite series (for orthorhombic space group Cmcm)

\begin{tabular}{|c|c|c|c|c|c|c|c|}
\hline & $\begin{array}{l}\text { Krásno A } \\
\text { this paper }\end{array}$ & $\begin{array}{l}\text { Krásno B } \\
\text { this paper }\end{array}$ & $\begin{array}{l}\text { Krásno C } \\
\text { this paper }\end{array}$ & $\begin{array}{l}\text { rockbridgeite } \\
\text { ICDD } 34-150\end{array}$ & $\begin{array}{l}\text { rockbridgeite } \\
\text { Moore (1970) }\end{array}$ & $\begin{array}{l}\text { frondelite } \\
\text { ICDD 35-625 }\end{array}$ & $\begin{array}{l}\text { frondelite } \\
\text { ICDD 8-83 }\end{array}$ \\
\hline $\mathrm{a}[\AA ⿻ \circ$ & $5.176(3)$ & $5.176(2)$ & $5.177(2)$ & $5.185(1)$ & $5.172(4)$ & $5.182(1)$ & 5.21 \\
\hline $\mathrm{b}[\AA]$ & $13.873(7)$ & $13.932(5)$ & $13.864(5)$ & $13.846(2)$ & $13.78(1)$ & $13.810(1)$ & 13.89 \\
\hline c [̊] & $16.810(8)$ & $16.811(6)$ & $16.878(5)$ & $16.782(2)$ & $16.805(9)$ & $16.968(3)$ & 17.01 \\
\hline $\mathrm{V}\left[\AA^{3}\right]$ & $1207.1(8)$ & $1212.4(6)$ & $1211.4(5)$ & 1204.8 & 1198.0 & 1214.3 & 1231.0 \\
\hline
\end{tabular}

$\mathrm{A}$ - Mn-rich rockbridgeite ( $A$-site: $\left.\mathrm{Fe}_{0.56} \mathrm{Mn}_{0.38} \mathrm{Zn}_{0.04} \mathrm{Ca}_{0.02}\right)$

B - black-green granular frondelite I $\left(A\right.$-site: $\left.\mathrm{Mn}_{0.82} \mathrm{Fe}_{0.07} \mathrm{Zn}_{0.07} \mathrm{Ca}_{0.02} \mathrm{Na}_{0.01}\right)$

$\mathrm{C}$ - brown-black frondelite II from radiating aggregate $\left(A\right.$-site: $\left.\mathrm{Mn}_{0.90} \mathrm{Zn}_{0.07} \mathrm{Ca}_{0.02} \mathrm{Na}_{0.01}\right)$ 


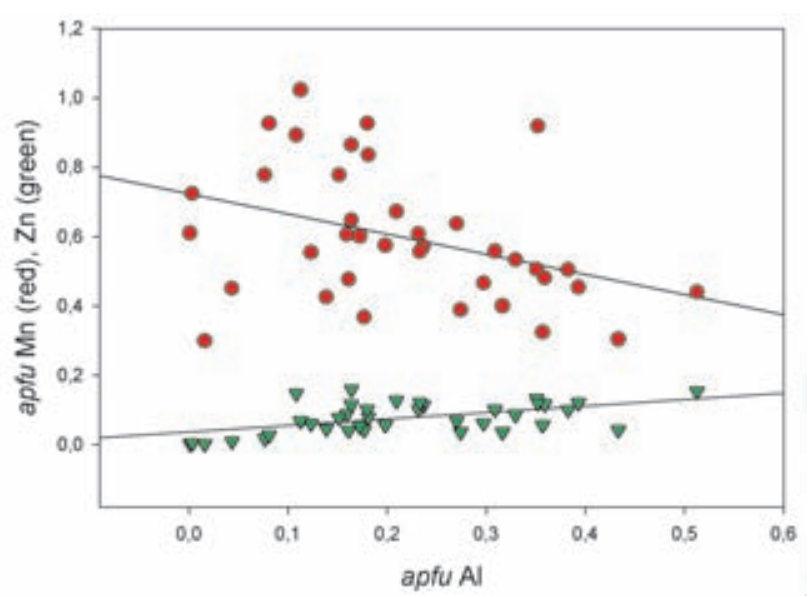

Fig. 51 Correlation of $\mathrm{Al}$ vs. $\mathrm{Mn}$ and $\mathrm{Zn}$ in minerals of the rockbridgeite - frondelite series from Krásno, expressed by regression curves. delite with Mn content 0.44-1.02 apfu Mn, $\mathrm{Fe}^{2+}$ (up to 0.44), $\mathrm{Zn}$ (up to 0.16), $\mathrm{Na}, \mathrm{Ca}$ and $\mathrm{Mg}$ (max. 0.08 apfu). Only several samples correspond to Mn-rich rockbridgeite with $\mathrm{Fe}^{2+}(0.45-0.63$ apfu) predominating above $\mathrm{Mn}(0.30-0.45 a p f u)$ and only minor $\mathrm{Zn}$ (up to 0.06 apfu). The $B$-site in frondelite and rockbridgeite (Fig. 50) contains in addition to $\mathrm{Fe}^{3+}$ also $\mathrm{Al}$ (up to 0.51 apfu) and minor Ti to $0.02 a p f u$. It is interesting that increasing Al in $B$-site correlates with decrease in $\mathrm{Mn}$ and increase in $\mathrm{Zn}$ in $A$-site (Fig. 51). The tetrahedral $T$-site contains besides predominating $\mathrm{P}$ only minor contents of $\mathrm{As}, \mathrm{Si}$ and S (max. 0.01-0.02 apfu). None of the studied samples shows substitution of $(\mathrm{OH})$ by $\mathrm{Cl}$ or $\mathrm{F}$. The empirical formulas calculated on the basis of $(\mathrm{P}+\mathrm{As}+\mathrm{S}+\mathrm{Si})=3$, corresponding to representative spot analyses of minerals of the rockbridgeite - frondelite series from Krásno, are presented in Table 17.
Table 17 Chemical composition of minerals of rockbridgeite - frondelite series (in wt. \%).

\begin{tabular}{|c|c|c|c|c|c|c|c|c|c|c|}
\hline & 1 & 2 & 3 & 4 & 5 & 6 & 7 & 8 & 9 & 10 \\
\hline $\mathrm{Na}_{2} \mathrm{O}$ & 0.01 & 0.02 & 0.00 & 0.03 & 0.07 & 0.00 & 0.00 & 0.07 & 0.12 & 0.16 \\
\hline $\mathrm{K}_{2} \mathrm{O}$ & 0.00 & 0.00 & 0.01 & 0.00 & 0.00 & 0.00 & 0.00 & 0.01 & 0.01 & 0.00 \\
\hline $\mathrm{CaO}$ & 0.24 & 0.15 & 0.12 & 0.00 & 0.08 & 0.07 & 0.07 & 0.37 & 0.02 & 0.31 \\
\hline $\mathrm{FeO}^{*}$ & 6.79 & 6.16 & 5.97 & 5.13 & 4.00 & 3.75 & 3.14 & 0.78 & 0.00 & 0.00 \\
\hline $\mathrm{BaO}$ & 0.15 & 0.07 & 0.13 & 0.04 & 0.00 & 0.28 & 0.03 & 0.00 & 0.11 & 0.00 \\
\hline $\mathrm{SrO}$ & 0.00 & 0.00 & 0.01 & 0.01 & 0.03 & 0.00 & 0.00 & 0.02 & 0.00 & 0.10 \\
\hline $\mathrm{MgO}$ & 0.03 & 0.03 & 0.03 & 0.11 & 0.11 & 0.07 & 0.00 & 0.04 & 0.03 & 0.05 \\
\hline $\mathrm{PbO}$ & 0.15 & 0.06 & 0.01 & 0.00 & 0.11 & 0.01 & 0.00 & 0.00 & 0.04 & 0.00 \\
\hline $\mathrm{CuO}$ & 0.09 & 0.02 & 0.00 & 0.51 & 0.00 & 0.21 & 0.00 & 0.00 & 0.00 & 0.00 \\
\hline $\mathrm{MnO}$ & 3.39 & 4.03 & 4.40 & 4.86 & 4.85 & 6.11 & 6.95 & 8.16 & 11.22 & 8.86 \\
\hline $\mathrm{ZnO}$ & 0.55 & 0.54 & 0.47 & 0.13 & 1.96 & 0.78 & 0.86 & 0.95 & 0.87 & 0.97 \\
\hline $\mathrm{Al}_{2} \mathrm{O}_{3}$ & 3.47 & 1.39 & 2.50 & 0.34 & 4.05 & 0.98 & 2.12 & 1.14 & 0.89 & 1.38 \\
\hline $\mathrm{Fe}_{2} \mathrm{O}_{3} *$ & 43.11 & 46.24 & 44.93 & 47.31 & 43.10 & 47.03 & 43.88 & 46.69 & 44.33 & 44.81 \\
\hline $\mathrm{TiO}_{2}$ & 0.02 & 0.03 & 0.02 & 0.06 & 0.08 & 0.04 & 0.13 & 0.20 & 0.19 & 0.01 \\
\hline $\mathrm{SiO}_{2}^{2}$ & 0.03 & 0.07 & 0.02 & 0.07 & 0.02 & 0.00 & 0.05 & 0.05 & 0.00 & 0.11 \\
\hline $\mathrm{As}_{2} \mathrm{O}_{5}$ & 0.07 & 0.00 & 0.01 & 0.00 & 0.26 & 0.23 & 0.09 & 0.01 & 0.00 & 0.00 \\
\hline $\mathrm{P}_{2} \mathrm{O}_{5}$ & 33.29 & 32.80 & 32.93 & 32.34 & 32.71 & 32.77 & 32.48 & 31.45 & 32.90 & 31.82 \\
\hline $\mathrm{SO}_{3}$ & 0.06 & 0.00 & 0.04 & 0.00 & 0.00 & 0.04 & 0.11 & 0.00 & 0.00 & 0.00 \\
\hline $\mathrm{H}_{2} \mathrm{O}^{*}$ & 6.54 & 6.63 & 6.77 & 6.58 & 7.02 & 6.72 & 6.35 & 7.12 & 6.15 & 6.37 \\
\hline total & 97.98 & 98.23 & 98.35 & 97.50 & 98.43 & 99.08 & 96.24 & 97.05 & 96.89 & 94.95 \\
\hline $\mathrm{Na}^{+}$ & 0.001 & 0.004 & 0.000 & 0.006 & 0.014 & 0.000 & 0.000 & 0.014 & 0.025 & 0.035 \\
\hline $\mathrm{K}^{+}$ & 0.000 & 0.000 & 0.001 & 0.000 & 0.000 & 0.000 & 0.000 & 0.002 & 0.002 & 0.000 \\
\hline $\mathrm{Ca}^{2+}$ & 0.028 & 0.017 & 0.014 & 0.000 & 0.009 & 0.008 & 0.008 & 0.045 & 0.003 & 0.037 \\
\hline $\mathrm{Fe}^{2+}$ & 0.602 & 0.556 & 0.537 & 0.470 & 0.359 & 0.336 & 0.285 & 0.074 & 0.000 & 0.000 \\
\hline $\mathrm{Ba}^{2+}$ & 0.006 & 0.003 & 0.005 & 0.002 & 0.000 & 0.012 & 0.001 & 0.000 & 0.004 & 0.000 \\
\hline $\mathrm{Sr}^{2+}$ & 0.000 & 0.000 & 0.001 & 0.001 & 0.002 & 0.000 & 0.000 & 0.001 & 0.000 & 0.006 \\
\hline $\mathrm{Mg}^{2+}$ & 0.004 & 0.005 & 0.004 & 0.018 & 0.018 & 0.011 & 0.000 & 0.007 & 0.005 & 0.008 \\
\hline $\mathrm{Pb}^{2+}$ & 0.004 & 0.002 & 0.000 & 0.000 & 0.003 & 0.000 & 0.000 & 0.000 & 0.001 & 0.000 \\
\hline $\mathrm{Cu}^{2+}$ & 0.007 & 0.001 & 0.000 & 0.042 & 0.000 & 0.017 & 0.000 & 0.000 & 0.000 & 0.000 \\
\hline $\mathrm{Mn}^{2+}$ & 0.304 & 0.369 & 0.400 & 0.451 & 0.440 & 0.555 & 0.638 & 0.778 & 1.024 & 0.836 \\
\hline $\mathrm{Zn}^{2+}$ & 0.043 & 0.043 & 0.037 & 0.010 & 0.155 & 0.061 & 0.069 & 0.079 & 0.069 & 0.080 \\
\hline subtotal & 1.000 & 1.000 & 1.000 & 1.000 & 1.000 & 1.000 & 1.000 & 1.000 & 1.133 & 1.001 \\
\hline $\mathrm{Al}^{3+}$ & 0.433 & 0.177 & 0.316 & 0.043 & 0.513 & 0.123 & 0.270 & 0.151 & 0.113 & 0.181 \\
\hline $\mathrm{Fe}^{3+}$ & 3.438 & 3.760 & 3.634 & 3.901 & 3.480 & 3.791 & 3.579 & 3.957 & 3.592 & 3.755 \\
\hline $\mathrm{Ti}^{4+}$ & 0.002 & 0.002 & 0.002 & 0.005 & 0.006 & 0.003 & 0.010 & 0.017 & 0.015 & 0.001 \\
\hline subtotal & 3.874 & 3.938 & 3.952 & 3.949 & 3.999 & 3.917 & 3.860 & 4.125 & 3.721 & 3.937 \\
\hline $\mathrm{Si}^{4+}$ & 0.003 & 0.008 & 0.002 & 0.008 & 0.002 & 0.000 & 0.005 & 0.006 & 0.000 & 0.012 \\
\hline $\mathrm{As}^{5+}$ & 0.004 & 0.000 & 0.000 & 0.000 & 0.014 & 0.013 & 0.005 & 0.001 & 0.000 & 0.000 \\
\hline $\mathrm{P}^{5+}$ & 2.988 & 2.992 & 2.994 & 2.992 & 2.983 & 2.984 & 2.981 & 2.993 & 3.000 & 2.987 \\
\hline$S^{6+}$ & 0.005 & 0.000 & 0.003 & 0.000 & 0.000 & 0.003 & 0.009 & 0.000 & 0.000 & 0.000 \\
\hline subtotal & 3.000 & 3.000 & 3.000 & 3.000 & 3.000 & 3.000 & 3.000 & 3.000 & 3.000 & 3.000 \\
\hline $\mathrm{OH}$ & 4.624 & 4.778 & 4.854 & 4.810 & 5.025 & 4.801 & 4.591 & 5.349 & 4.418 & 4.732 \\
\hline
\end{tabular}

1-4 rockbridgeite, Krásno; 5-10 frondelite, Krásno

$\mathrm{FeO}^{*}$ and $\mathrm{Fe}_{2} \mathrm{O}_{3} *$ - calculated on the basis of assumed occupancy of $A$ - and $B$ - sites, $\mathrm{H}_{2} \mathrm{O}^{*}$ - calculated on the basis of charge balance.

\section{Goyazite}

see minerals of the crandallite group

\section{Isokite $\mathrm{CaMg}\left(\mathrm{PO}_{4}\right) \mathrm{F}$}

Fischer (1957) described isokite in samples collected by J. Kutina on dumps in the Horní Slavkov ore district (mining area at the Schnöd stock) as fine-grained compact aggregates in association with triplite and (fluor)apatite. Fisher (1957) in his somewhat tentative interpretation assumed that isokite was formed by a late hydrothermal alteration of dark ("light brown") type of triplite and mentioned its formation in the sequence triplite - isokite - apatite. Information obtained in the present study indicates that some data presented by Fisher (1957) are somewhat problematic, in particular the position of apatite, which he considered as younger than isokite, and particularly the suggestion concerning quartz: ("... quartz formed post-isokite.").

During our research, isokite has been identified as one of the most widespread phosphates in the Krásno ore district. It is probable that in the past, isokite was considered compact fluorapatite, due to its inconspicuous appearance. Newly studied isokite samples come from numerous places in the Huber open pit, from phosphate accumulations at the $5^{\text {th }}$ level of Huber shaft and it was identified in historical museum specimens from the Gellnauer vein system. No differences have been noted in macroscopic and microscopic properties among isokite samples collected at various partial localities. 
The most common and inconspicuous form of isokite is as rather hard and compact fine-grained aggregates of light pink, pink-brown to light brown colour with a weak greasy lustre, up to $10 \mathrm{~cm}$ across (Fig. 52). Isokite is intergrown with variable quantity of older fluorapatite in these aggregates, which are macroscopically indistinquishable from aggregates of fluorapatite around older triplite (with various colour), always intergrown in massive and coarse-grained quartz. The microscopic observations show that isokite always replaced only fluorapatite and not directly triplite (Fig. 53). The observed interfaces triplite - isokite are free of indications of alteration, but isokite aggregates often contain fluorapatite relics (Fig. 54). Hochleitner - Fehr (2005) described a similar occurrence of compact isokite formed in the sequnce triplite - Mn-rich fluorapatite - isokite from pegmatite at Senhora de Assunçăo (Portugal).

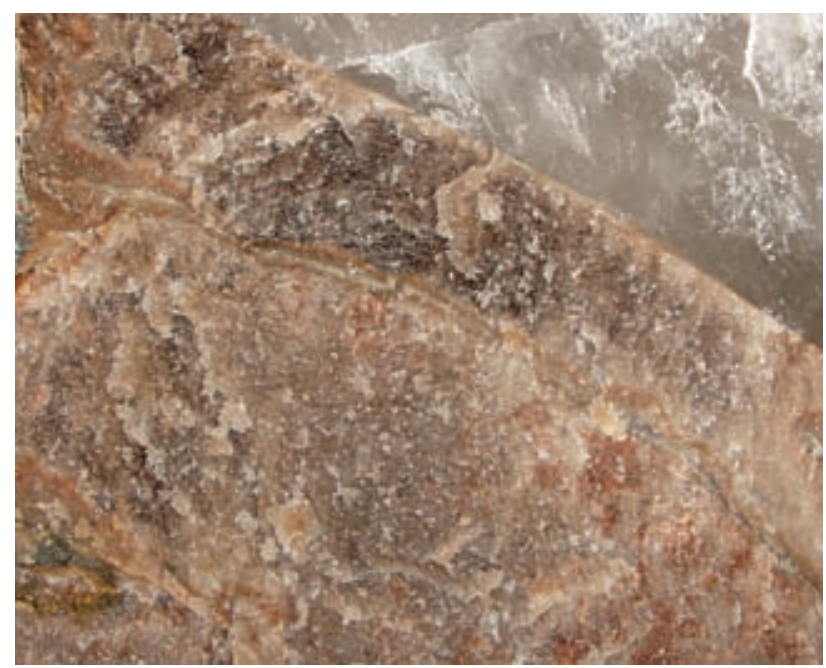

Fig. 52 Aggregates of compact isokite (intergrown with fluorapatite) around aggregates of older triplite with white quartz. $5^{\text {th }}$ level of the Huber shaft, Krásno. Width of photo $20 \mathrm{~mm}$. Nicon SMZ1500 microphotography by J. \& E. Sejkora.

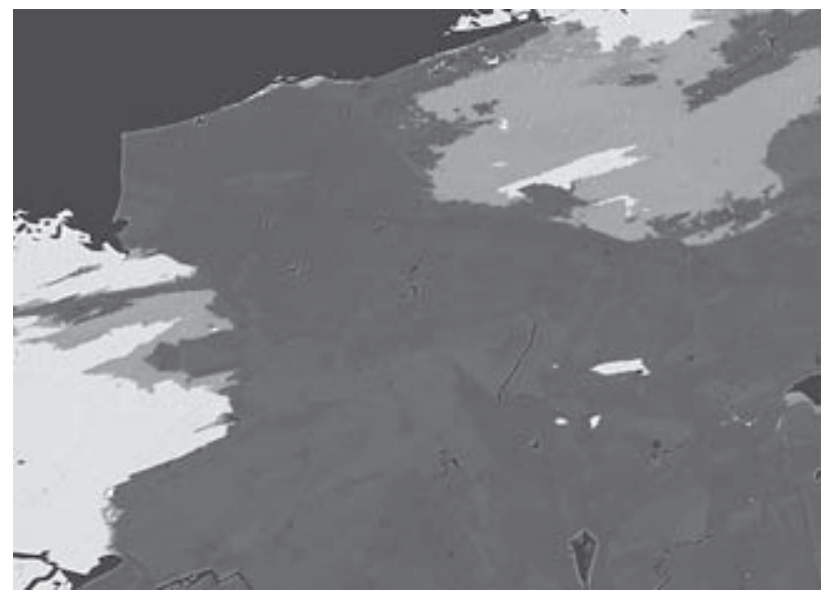

Fig. 53 Irregular zoned aggregate of isokite (dark) replacing fluorapatite (grey), which replaced the oldest mineral triplite (white), Huber open pit, Krásno. Width of photo $500 \mu \mathrm{m}$. BSE photograph Cameca SX100 by J. Sejkora and R. Škoda.
A second type of isokite forms soft, incoherent to earthy aggregates, up to $5 \mathrm{~cm}$ in size, of whitish, yellowish, light pink to yellow-brown colour. It is macroscopically more conspicuous than isokite of the first type. It is associated with compact isokite aggregates of the first type, fluorapatite and triplite. The soft isokite II aggregates are composed of fine, equant and usually corroded grains less than $0.1 \mathrm{~mm}$ in size (Fig. 55). Analyses of both types of isokite from various places show chemical and X-ray diffraction identity. In the preferred interpretation, soft isokite II was produced by weathering of less stable fluorapatite in compact isokite+fluorapatite aggregates, not formed as a younger (second) generation of isokite. Isokite I and II are associated with fluorapatite, triplite (zwieselite), minerals of the rockbridgeite - frondelite series, rare whitmoreite, turquoise group minerals, strengite, $U N K 3$, zircon, $\mathrm{Nb}$-rich rutile and sulfides (arsenopyrite, chalcopyrite etc.). Small parallel aggregates of acicular isokite III crystals of mm scale have been observed in cavities of phosphate accumulations (Fig. 56). This very rare type of isokite III probably rep-

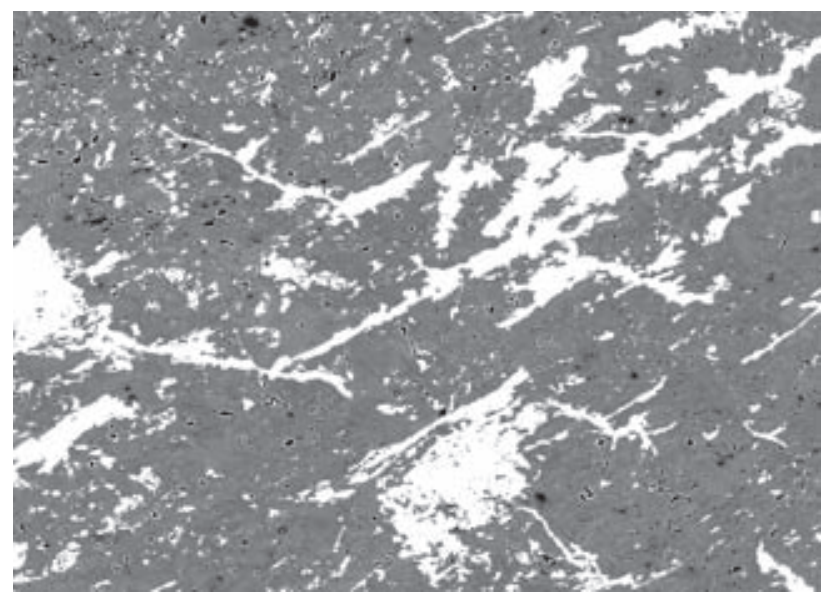

Fig. 54 Isokite aggregate (darker groundmass) with numerous replacement relics of fluorapatite (light). Huber open pit, Krásno. Width of photo $800 \mu \mathrm{m}$. BSE photograph Cameca SX100 by J. Sejkora and R. Škoda.

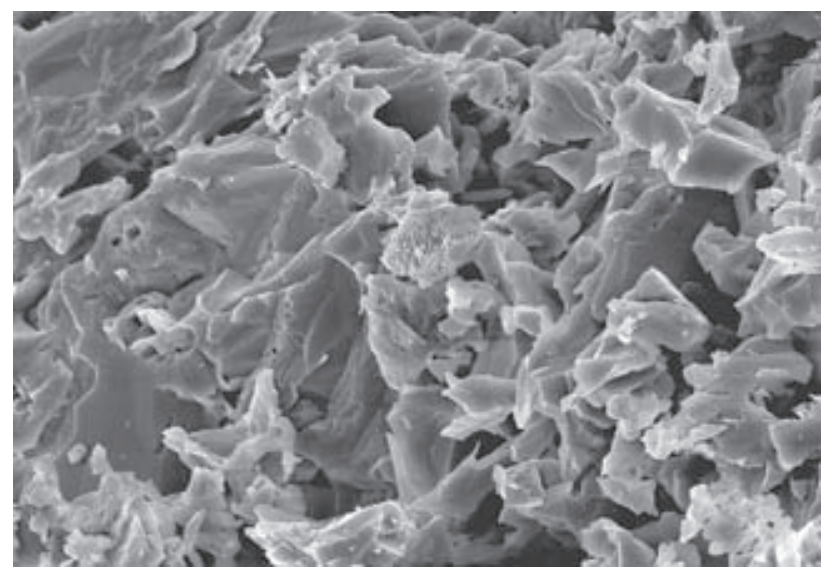

Fig. 55 Irregular isokite grains. $5^{\text {th }}$ level of the Huber shaft, Krásno. Width of photo $60 \mu \mathrm{m}$. SEM photograph by J. Sejkora. 


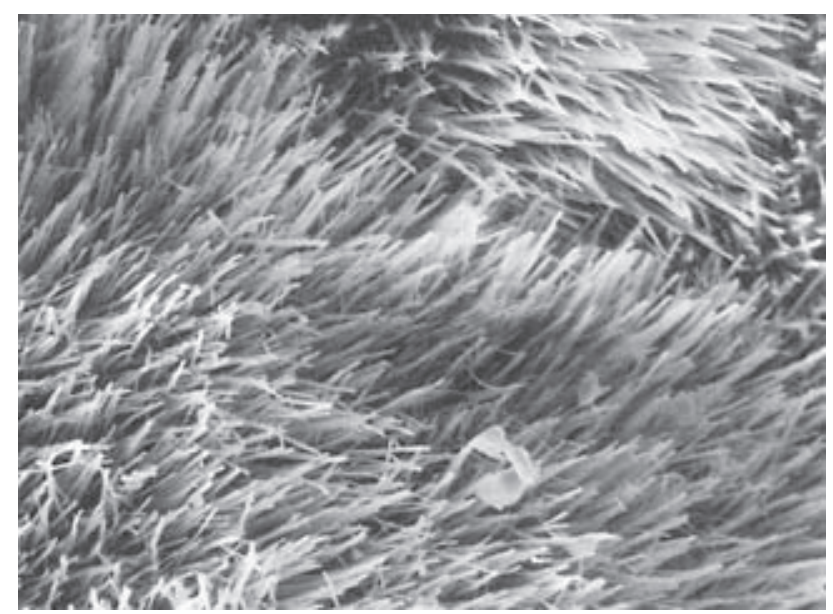

Fig. 56 Aggregate of isokite acicular crystals in parallel growth. Huber open pit, Krásno. Width of photo $130 \mu \mathrm{m}$. SEM photograph by M. Fikar.
Ca, $B$-site by $\mathrm{Mg}$, tetrahedral $T$-site by $\mathrm{P}$ and $Z$-site by $\mathrm{F}$ (isokite) or OH (panasqueiraite, Isaacs - Peacor 1981). The isokite chemical composition in all analyzed samples is rather similar and is very close to the end member composition (Table 20). Fluorine content shows a higher variability (Fig. 57), from the Huber open pit $(0.68-0.84)$ to the $5^{\text {th }}$ level of the Huber shaft $(0.78-0.91$ apfu F). Ca and $\mathrm{Mg}$ contents ( $A$ - and $B$ - site) are near the theoretical ratio $1: 1(0.95-1.01$ apfu $\mathrm{Ca} ; 0.86-1.01$ apfu $\mathrm{Mg})$. The minor contents of Fe (0.01-0.08 apfu, in samples from the Gellnauer vein system 0.10-0.12 apfu) and $\mathrm{Mn}$ (0.01-0.02 apfu) enter the isokite structure by substitutions (Fe, Mn) Ca $\mathrm{C}_{-1}$ and (Fe, Mn) Mg $\mathrm{Mg}_{-1}$, without showing a preference for one of the alternatives (Fig. 58). Analyzed samples from the $5^{\text {th }}$ level of the Huber shaft show slightly increased contents of $\mathrm{Na}$ (Fig. 59) and $\mathrm{S}$ (Fig. 60) in comparison with other samples. The Na con-

Table 18 X-ray powder diffraction pattern of isokite

\begin{tabular}{|c|c|c|c|c|c|c|c|c|c|c|c|c|c|c|}
\hline$I_{r e l}$ & $d$ & $h$ & $k$ & $l$ & $I_{r e l}$ & $d$ & $h$ & $k$ & $l$ & $I_{r e l}$ & $d$ & $h$ & $k$ & $l$ \\
\hline 17 & 4.377 & 0 & 2 & 0 & 26 & 2.0690 & 0 & 4 & 1 & 13 & 1.5368 & 1 & 3 & -4 \\
\hline 13 & 3.614 & 0 & 2 & 1 & 25 & 2.0393 & 3 & 1 & -1 & 13 & 1.5199 & 4 & 2 & -2 \\
\hline 39 & 3.198 & 0 & 0 & 2 & 14 & 1.9598 & 3 & 1 & -3 & 9 & 1.5073 & 4 & 0 & -4 \\
\hline 100 & 3.177 & 1 & 1 & 1 & 19 & 1.8829 & 1 & 3 & -3 & 10 & 1.4949 & 3 & 3 & -4 \\
\hline 68 & 3.016 & 2 & 0 & -2 & 16 & 1.8709 & 2 & 0 & -4 & 22 & 1.4795 & 1 & 3 & 3 \\
\hline 31 & 2.7833 & 2 & 0 & 0 & 24 & 1.8052 & 0 & 4 & 2 & 5 & 1.4505 & 3 & 1 & -5 \\
\hline 86 & 2.6253 & 1 & 3 & -1 & 12 & 1.7710 & 1 & 1 & -4 & 11 & 1.4269 & 1 & 5 & -3 \\
\hline 49 & 2.5829 & 0 & 2 & 2 & 11 & 1.7387 & 3 & 3 & -2 & 9 & 1.4214 & 2 & 4 & -4 \\
\hline 49 & 2.5829 & 1 & 3 & 0 & 63 & 1.7192 & 2 & 2 & -4 & 15 & 1.3917 & 4 & 0 & 0 \\
\hline 7 & 2.4845 & 2 & 2 & -2 & 27 & 1.7052 & 2 & 0 & 2 & 11 & 1.3863 & 3 & 3 & 1 \\
\hline 2 & 2.3782 & 1 & 1 & -3 & 7 & 1.6850 & 1 & 1 & 3 & 14 & 1.3435 & 3 & 5 & -1 \\
\hline 44 & 2.2987 & 1 & 3 & -2 & 9 & 1.6693 & 1 & 5 & 0 & 17 & 1.3127 & 2 & 6 & -2 \\
\hline 33 & 2.2287 & 1 & 1 & 2 & 28 & 1.6552 & 3 & 3 & -3 & 12 & 1.3026 & 4 & 4 & -2 \\
\hline 35 & 2.2155 & 1 & 3 & 1 & 12 & 1.6020 & 0 & 0 & 4 & 13 & 1.2769 & 1 & 3 & -5 \\
\hline 29 & 2.1035 & 3 & 1 & -2 & 25 & 1.5564 & 1 & 5 & 1 & 15 & 1.2343 & 2 & 0 & -6 \\
\hline
\end{tabular}

Table 19 Unit-cell parameters of isokite (for monoclinic space group $C 2 / c$ )

\begin{tabular}{|l|ccc|}
\hline & $\begin{array}{c}\text { Krásno } \\
\text { this paper }\end{array}$ & $\begin{array}{c}\text { Senhora de Assunção } \\
\text { Hochleitner - Fehr (2005) }\end{array}$ & $\begin{array}{c}\text { Isoka } \\
\text { Deans - McConnell (1955) }\end{array}$ \\
\hline $\mathrm{a}[\AA]$ & $6.517(1)$ & $6.527(5)$ & $6.52(5)$ \\
$\mathrm{b}[\AA]$ & $8.746(1)$ & $8.744(5)$ & $8.75(5)$ \\
$\mathrm{c}[\AA]$ & $7.499(1)$ & $7.501(6)$ & $7.51(5)$ \\
$\beta\left[{ }^{\circ}\right]$ & $121.35(1)$ & $121.34(1)$ & $121.5(2)$ \\
$\mathrm{V}\left[\AA^{3}\right]$ & $365.0(1)$ & 365.68 & 365.3 \\
\hline
\end{tabular}

resents a true younger, remobilized generation of this mineral.

X-ray powder diffraction data for isokite from Krásno (Table 18) correspond to published data. The unit-cell parameters were refined in the space group $C 2 / c$ (Table 19). The alternative of non-standard space group $A 2 / a$, proposed by Jaffe et al. (1992) with regard to probable isostructural relation of isokite to titanite (Povarennykh 1972), yields on theoretical calculation of diffraction maxima intensity values which do not correspond to experimentally obtained patterns.

The general chemical formula for isokite-related minerals is $\mathrm{AB}\left(\mathrm{TO}_{4}\right) \mathrm{Z}$. The $A$-site is occupied dominantly by

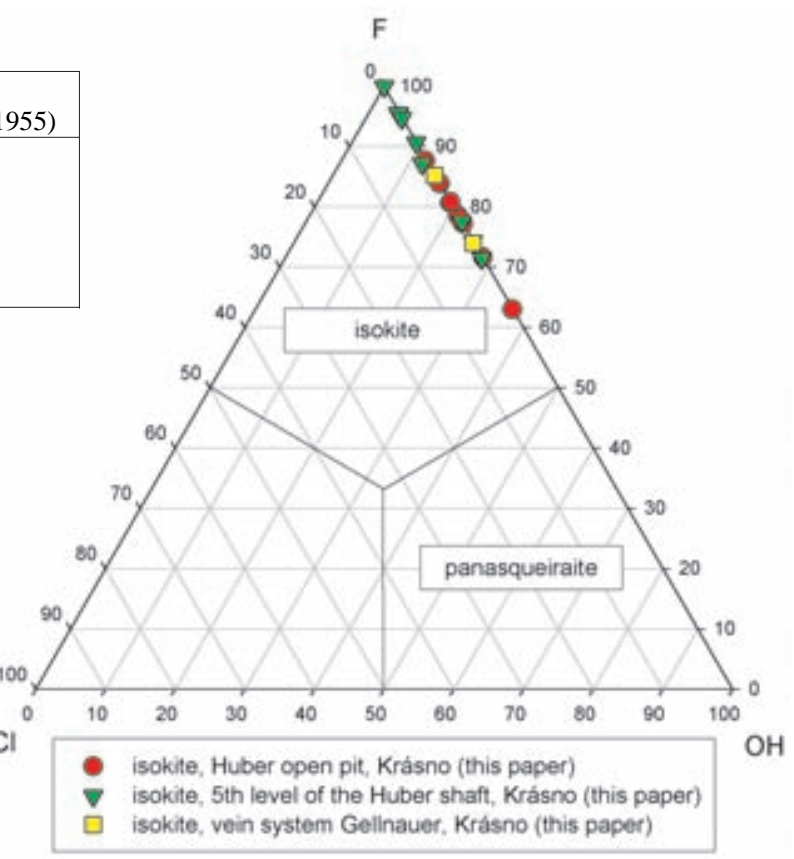

Fig. 57 Ternary plot of F-Cl-OH occupancy in Z-site (atomic ratio) for isokite from Krásno. 
Table 20 Chemical composition of isokite (in wt. \%)

\begin{tabular}{|c|c|c|c|c|c|c|c|c|}
\hline & M & $\mathrm{O}$ & M & $\mathrm{M}$ & $\mathrm{G}$ & G & $\mathrm{M}$ & $\mathrm{M}$ \\
\hline $\mathrm{Na}_{2} \mathrm{O}$ & 0.34 & 0.04 & 0.18 & 0.08 & 0.11 & 0.15 & 0.07 & 0.06 \\
\hline $\mathrm{K}_{2} \mathrm{O}$ & 0.02 & 0.01 & 0.01 & 0.01 & 0.00 & 0.00 & 0.02 & 0.02 \\
\hline $\mathrm{CaO}$ & 30.75 & 31.05 & 30.33 & 30.84 & 29.19 & 29.97 & 31.53 & 32.11 \\
\hline $\mathrm{SrO}$ & 0.01 & 0.07 & 0.12 & 0.00 & 0.06 & 0.04 & 0.02 & 0.06 \\
\hline $\mathrm{BaO}$ & 0.00 & 0.13 & 0.00 & 0.00 & 0.00 & 0.04 & 0.13 & 0.00 \\
\hline $\mathrm{MgO}$ & 21.32 & 21.68 & 20.83 & 19.74 & 20.68 & 18.97 & 20.91 & 21.24 \\
\hline $\mathrm{MnO}$ & 0.73 & 0.52 & 0.44 & 0.70 & 0.32 & 0.50 & 0.27 & 0.38 \\
\hline $\mathrm{FeO}$ & 1.73 & 1.44 & 1.32 & 2.31 & 4.86 & 4.17 & 1.48 & 1.01 \\
\hline $\mathrm{CuO}$ & 0.00 & 0.00 & 0.24 & 0.01 & 0.23 & 0.07 & 0.00 & 0.10 \\
\hline $\mathrm{ZnO}$ & 0.06 & 0.08 & 0.00 & 0.00 & 0.00 & 0.09 & 0.04 & 0.11 \\
\hline $\mathrm{PbO}$ & 0.04 & 0.02 & 0.00 & 0.07 & 0.00 & 0.03 & 0.14 & 0.00 \\
\hline $\mathrm{Al}_{2} \mathrm{O}_{3}$ & 0.00 & 0.00 & 0.00 & 0.03 & 0.07 & 0.00 & 0.05 & 0.03 \\
\hline $\mathrm{TiO}_{2}$ & 0.13 & 0.01 & 0.25 & 0.04 & 0.08 & 0.14 & 0.01 & 0.07 \\
\hline $\mathrm{SiO}_{2}$ & 0.00 & 0.00 & 0.04 & 0.04 & 0.06 & 0.00 & 0.05 & 0.10 \\
\hline $\mathrm{P}_{2} \mathrm{O}_{5}$ & 39.36 & 40.27 & 39.38 & 38.68 & 38.10 & 37.96 & 40.19 & 40.13 \\
\hline $\mathrm{As}_{2} \mathrm{O}_{5}$ & 0.02 & 0.08 & 0.00 & 0.00 & 0.02 & 0.13 & 0.00 & 0.00 \\
\hline $\mathrm{SO}_{3}$ & 0.51 & 0.14 & 0.34 & 0.25 & 0.25 & 0.13 & 0.00 & 0.00 \\
\hline $\mathrm{Cl}$ & 0.19 & 0.02 & 0.04 & 0.02 & 0.06 & 0.03 & 0.02 & 0.01 \\
\hline $\mathrm{F}$ & 9.36 & 8.02 & 9.36 & 9.45 & 8.56 & 8.89 & 9.40 & 9.48 \\
\hline$-\mathrm{O}=\mathrm{F} \cdot \mathrm{Cl}$ & -3.98 & -3.38 & -3.95 & -3.98 & -3.62 & -3.75 & -3.96 & -3.99 \\
\hline$* \mathrm{H}_{2} \mathrm{O}$ & 0.57 & 1.02 & 0.20 & 0.24 & 1.32 & 0.66 & 0.23 & 0.42 \\
\hline total & 101.141 & 101.22 & 99.11 & 98.521 & 100.35 & 98.231 & 100.611 & 101.32 \\
\hline $\mathrm{Na}^{+}$ & 0.020 & 0.002 & 0.010 & 0.005 & 0.006 & 0.009 & 0.004 & 0.003 \\
\hline $\mathrm{K}^{+}$ & 0.001 & 0.000 & 0.000 & 0.001 & 0.000 & 0.000 & 0.001 & 0.001 \\
\hline $\mathrm{Ca}^{2+}$ & 0.974 & 0.969 & 0.964 & 0.999 & 0.959 & 0.991 & 0.989 & 1.007 \\
\hline $\mathrm{Sr}^{2+}$ & 0.000 & 0.001 & 0.002 & 0.000 & 0.001 & 0.001 & 0.000 & 0.001 \\
\hline $\mathrm{Ba}^{2+}$ & 0.000 & 0.001 & 0.000 & 0.000 & 0.000 & 0.000 & 0.002 & 0.000 \\
\hline $\mathrm{Mg}^{2+}$ & 0.940 & 0.941 & 0.921 & 0.890 & 0.945 & 0.873 & 0.912 & 0.926 \\
\hline $\mathrm{Mn}^{2+}$ & 0.018 & 0.013 & 0.011 & 0.018 & 0.008 & 0.013 & 0.007 & 0.009 \\
\hline $\mathrm{Fe}^{2+}$ & 0.043 & 0.035 & 0.033 & 0.058 & 0.125 & 0.108 & 0.036 & 0.025 \\
\hline $\mathrm{Cu}^{2+}$ & 0.000 & 0.000 & 0.005 & 0.000 & 0.005 & 0.002 & 0.000 & 0.002 \\
\hline $\mathrm{Zn}^{2+}$ & 0.001 & 0.002 & 0.000 & 0.000 & 0.000 & 0.002 & 0.001 & 0.002 \\
\hline $\mathrm{Pb}^{2+}$ & 0.000 & 0.000 & 0.000 & 0.001 & 0.000 & 0.000 & 0.001 & 0.000 \\
\hline $\mathrm{Al}^{3+}$ & 0.000 & 0.000 & 0.000 & 0.001 & 0.002 & 0.000 & 0.002 & 0.001 \\
\hline $\mathrm{Ti}^{4+}$ & 0.003 & 0.000 & 0.006 & 0.001 & 0.002 & 0.003 & 0.000 & 0.002 \\
\hline subtotal & 1.998 & 1.965 & 1.946 & 1.973 & 2.052 & 1.999 & 1.954 & 1.977 \\
\hline $\mathrm{Si}^{4+}$ & 0.000 & 0.000 & 0.001 & 0.001 & 0.002 & 0.000 & 0.002 & 0.003 \\
\hline $\mathrm{P}^{5+}$ & 0.988 & 0.996 & 0.991 & 0.993 & 0.992 & 0.995 & 0.998 & 0.997 \\
\hline $\mathrm{As}^{5+}$ & 0.000 & 0.001 & 0.000 & 0.000 & 0.000 & 0.002 & 0.000 & 0.000 \\
\hline $\mathrm{S}^{6+}$ & 0.011 & 0.003 & 0.007 & 0.006 & 0.006 & 0.003 & 0.000 & 0.000 \\
\hline subtotal & 1.000 & 1.000 & 1.000 & 1.000 & 1.000 & 1.000 & 1.000 & 1.000 \\
\hline $\mathrm{F}^{-}$ & 0.875 & 0.738 & 0.878 & 0.903 & 0.830 & 0.867 & 0.870 & 0.877 \\
\hline $\mathrm{Cl}^{-}$ & 0.009 & 0.001 & 0.002 & 0.001 & 0.003 & 0.002 & 0.001 & 0.001 \\
\hline$* \mathrm{OH}^{-}$ & 0.113 & 0.199 & 0.040 & 0.050 & 0.266 & 0.136 & 0.045 & 0.083 \\
\hline subtotal & 0.998 & 0.939 & 0.920 & 0.954 & 1.100 & 1.005 & 0.915 & 0.960 \\
\hline
\end{tabular}

$\mathrm{M}-5^{\text {th }}$ level, Huber shaft; $\mathrm{O}-$ Huber open pit; $\mathrm{G}-$ Gellnauer vein system. Empirical formulas were calculated on the basis of $(\mathrm{P}+\mathrm{As}+\mathrm{S}+\mathrm{Si})=1$ and charge balance; $\mathrm{H}_{2} \mathrm{O}$ content is calculated from charge balance.

tent is probably not controlled by the substitution NaAl$\mathrm{Ca}_{-1} \mathrm{Mg}_{-1}$, as could be suggested by structural relationship with lacroixite $\mathrm{NaAlPO}_{4}(\mathrm{~F}, \mathrm{OH})$ ), but probably by substitution of the type $\mathrm{NaSR}^{2+}{ }_{-1} \mathrm{P}_{-1}$ (Fig. 59), which is related to a hypothetic end-member composition $\mathrm{NaR}^{2+} \mathrm{SO}_{4}(\mathrm{~F}, \mathrm{OH})$. The empirical formulas of isokite from Krásno calculated on the basis of $(\mathrm{P}+\mathrm{As}+\mathrm{S}+\mathrm{Si})=1$ are given in Table 20 .

\section{Kolbeckite $\mathrm{ScPO}_{4} \cdot 2 \mathrm{H}_{2} \mathrm{O}$}

The uncommon occurences of kolbeckite are tied to irregular cavities (up to $6 \mathrm{~cm}$ ) in strongly altered phosphate accumulations (fluorapatite and isokite; rarely with triplite relics) in the Huber open pit. The mineral forms

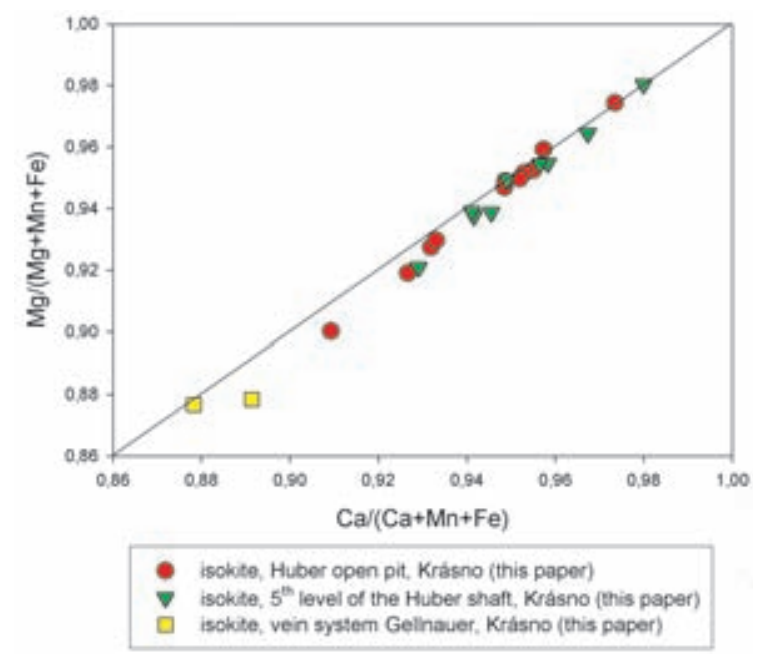

Fig. 58 Correlation of $\mathrm{Ca} /(\mathrm{Ca}+\mathrm{Mn}+\mathrm{Fe})$ and $\mathrm{Mg} /(\mathrm{Mg}+\mathrm{Mn}+\mathrm{Fe})$ for isokite from Krásno close to 1:1 (indicated by line) shows no preference in entry of $\mathrm{Mn}$ and $\mathrm{Fe}$ in the Ca-site or the $\mathrm{Mg}$-site, respectively. Concentrations of elements are in apfu.

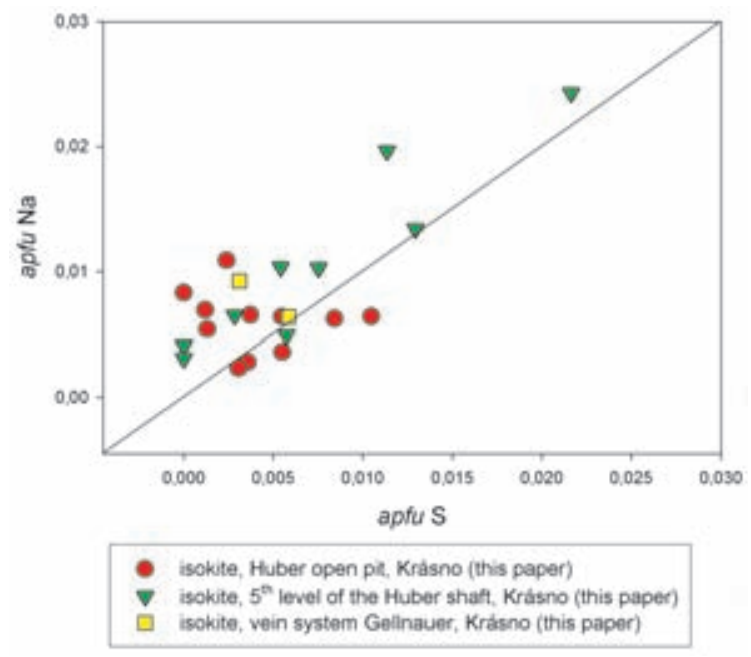

Fig. 59 A plot of apfu $\mathrm{S}$ vs. Na in isokite from Krásno. Positive corelation of $\mathrm{Na}$ and $\mathrm{S}$ close to $1: 1$ (indicated by line) suggests substitution $\mathrm{NaSR}_{-1}^{2+} \mathrm{P}_{-1}$.

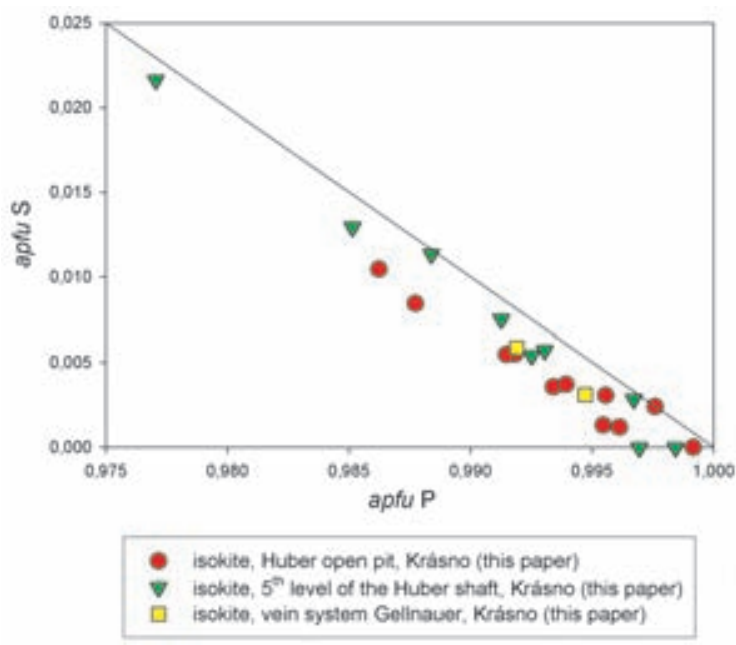

Fig. 60 A plot of apfu P vs. apfu S for isokite from Krásno. The line corresponds to an ideal correlation $\mathrm{P}+\mathrm{S}=1$. 
minute crystalline aggregates of whitish colour, up to $200 \mu \mathrm{m}$ large. The white colour of kolbeckite, relative to distinctly blue kolbeckite crystals from the nearby locality Vysoký kámen (Sejkora et al. 2006), makes the min-

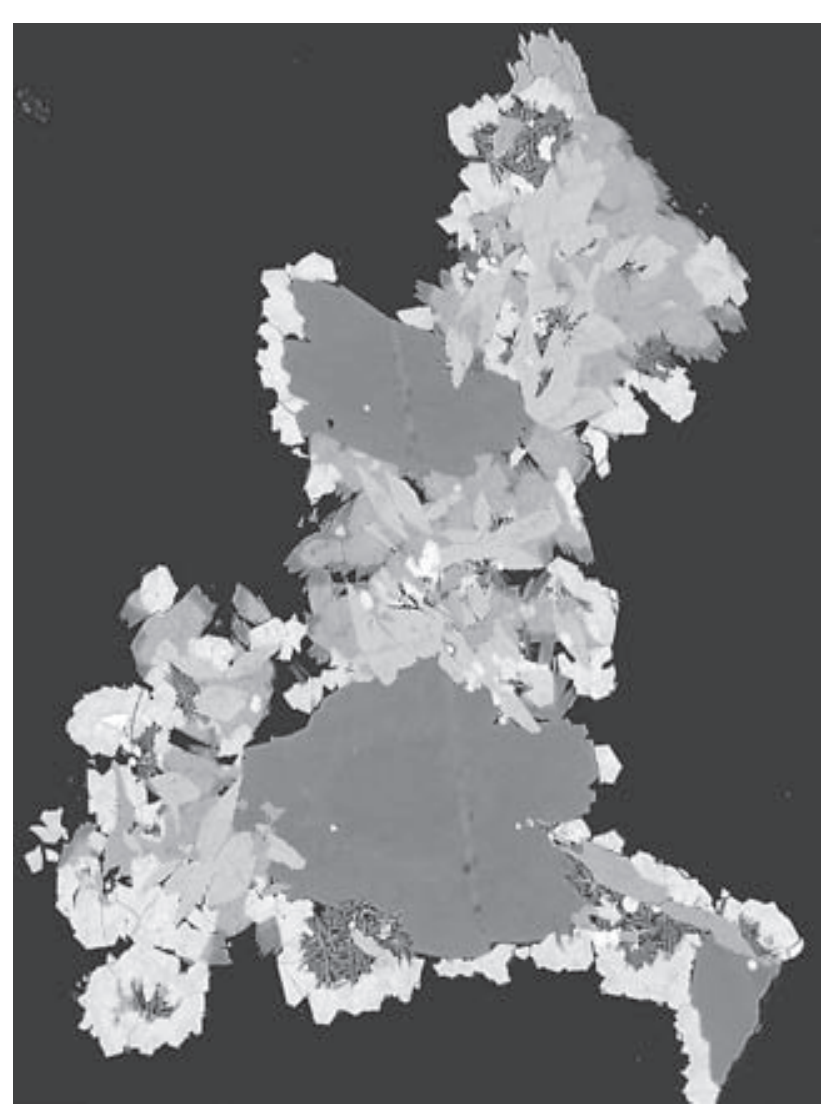

Fig. 61 Kolbeckite aggregates (dark grey) overgrown by elongated crystals of UNK3 (in places with rhombic shapes), zoned aggregates of mineral of the turquoise group (darker) and pharmacosiderite crystals (light); also present are distinctly tabular aggregates of $U N K 1$. Huber open pit, Krásno. Width of photo $400 \mu \mathrm{m}$. Cameca SX100, BSE photograph by J. Sejkora and R. Škoda.

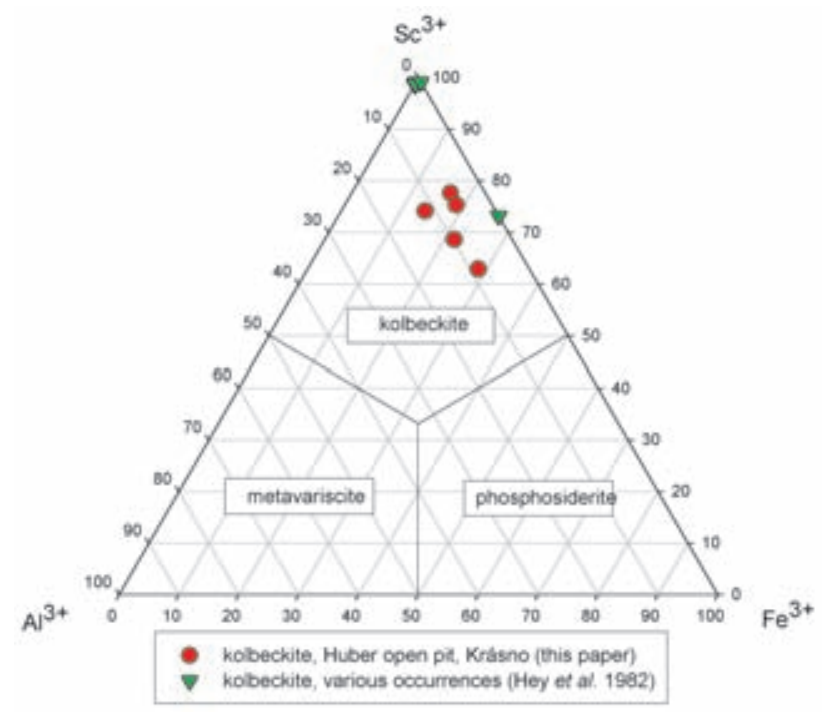

Fig. 62 Ternary plot of Sc-Fe-Al occupancy of cation site (atomic ratio) for kolbeckite. eral inconspicuous and similar, both macroscopically and microscopically, to aggregates of late fluorapatite or leucophosphite. Kolbeckite aggregates (Fig. 61) are usually intergrown with minerals of the turquoise group, $U N K 3$, pharmacosiderite, UNK1 and closely associated with fluorapatite, leucophosphite and rutile.

Due to the small size of the aggregates, kolbeckite samples were examined only by electron microprobe (Table 21). The cation-group in kolbeckite (Fig. 62) contains besides the dominant Sc (0.63-0.75 apfu) significant Al (0.06-0.11 apfu) and especially $\mathrm{Fe}^{3+}(0.14-0.28$ apfu). $\mathrm{Up}$ to present, significant $\mathrm{Fe}^{3+}(0.28 \mathrm{apfu})$ contents were reported only in kolbeckite from Potash Sulfur Springs, Arkansas (Hey et al. 1982). In the anion group, dominant $\mathrm{P}$ is accompanied by low As (up to c. 0.02 apfu) and traces of $\mathrm{S}$ and $\mathrm{Si}(\max 0.002 a p f u)$. The empirical formula of kolbeckite from the Huber open pit is $\left(\mathrm{Sc}_{0.70} \mathrm{Fe}_{0.19} \mathrm{Al}_{0.08}\right)_{\Sigma 0.97}\left(\mathrm{PO}_{4}\right)_{1.00} \cdot 2.00 \mathrm{H}_{2} \mathrm{O}$.

Table 21 Chemical composition of kolbeckite (in wt. \%)

\begin{tabular}{|l|rrrrrrr|}
\hline & mean & 1 & 2 & 3 & 4 & 5 & $* 1$ \\
\hline $\mathrm{ZnO}$ & 0.34 & 0.64 & 0.54 & 0.42 & 0.00 & 0.12 & \\
$\mathrm{MnO}$ & 0.06 & 0.00 & 0.00 & 0.03 & 0.09 & 0.17 & \\
$\mathrm{CaO}$ & 0.06 & 0.00 & 0.12 & 0.08 & 0.05 & 0.07 & \\
$\mathrm{PbO}$ & 0.05 & & & & 0.13 & 0.11 & \\
$\mathrm{BaO}$ & 0.04 & 0.00 & 0.00 & 0.06 & 0.00 & 0.15 & \\
$\mathrm{Sc}_{2} \mathrm{O}_{3}$ & 26.53 & 25.83 & 28.65 & 27.38 & 23.49 & 27.32 & 39.19 \\
$\mathrm{Al}_{2} \mathrm{O}_{3}$ & 2.29 & 2.70 & 1.58 & 1.61 & 2.36 & 3.21 & \\
$\mathrm{Fe}_{2} \mathrm{O}_{3}$ & 8.55 & 9.45 & 7.07 & 7.88 & 12.35 & 6.01 & \\
$\mathrm{SiO}_{2}$ & 0.03 & 0.00 & 0.03 & 0.03 & 0.03 & 0.05 & \\
$\mathrm{As}_{2} \mathrm{O}_{5}$ & 0.60 & 0.75 & 0.54 & 0.92 & 0.69 & 0.11 & \\
$\mathrm{P}_{2} \mathrm{O}_{5}$ & 39.03 & 39.37 & 39.29 & 38.30 & 38.25 & 39.94 & 40.33 \\
$\mathrm{SO}_{3}$ & 0.04 & 0.03 & 0.08 & 0.00 & 0.00 & 0.09 & \\
$\mathrm{H}_{2} \mathrm{O}^{*}$ & 20.28 & 20.31 & 20.30 & 20.15 & 20.12 & 20.44 & 20.48 \\
$\mathrm{total}_{\mathrm{Ca}}$ & 97.91 & 99.06 & 98.21 & 96.86 & 97.54 & 97.78 & 100.00 \\
$\mathrm{Ba}$ & 0.002 & 0.000 & 0.004 & 0.003 & 0.002 & 0.002 & 0.000 \\
$\mathrm{~Pb}_{\mathrm{Mn}}$ & 0.000 & 0.000 & 0.000 & 0.001 & 0.000 & 0.002 & 0.000 \\
$\mathrm{Zn}$ & 0.000 & 0.000 & 0.000 & 0.000 & 0.001 & 0.001 & 0.000 \\
$\mathrm{Al}$ & 0.002 & 0.000 & 0.000 & 0.001 & 0.002 & 0.004 & 0.000 \\
$\mathrm{Fe}^{3+}$ & 0.008 & 0.014 & 0.012 & 0.009 & 0.000 & 0.003 & 0.000 \\
$\mathrm{Sc}^{3+}$ & 0.082 & 0.095 & 0.056 & 0.058 & 0.085 & 0.113 & 0.000 \\
$\mathrm{Si}^{3+}$ & 0.194 & 0.212 & 0.160 & 0.182 & 0.284 & 0.135 & 0.000 \\
$\mathrm{As}^{5+}$ & 0.699 & 0.671 & 0.751 & 0.733 & 0.625 & 0.714 & 1.000 \\
$\mathrm{P}^{5+}$ & 0.001 & 0.000 & 0.001 & 0.001 & 0.001 & 0.002 & 0.000 \\
$\mathrm{~S}^{6+}$ & 0.999 & 0.994 & 1.001 & 0.996 & 0.990 & 1.013 & 1.000 \\
$\mathrm{H}^{+}$ & 0.001 & 0.001 & 0.002 & 0.000 & 0.000 & 0.002 & 0.000 \\
$\mathrm{H}_{2} \mathrm{O}$ & 2.002 & 4.004 & 4.002 & 3.998 & 4.001 & 3.996 & 4.001 \\
& 2.001 & 2.002 & 2.001 & 1.999 & 2.000 & 1.998 & 2.000 \\
\hline & & & & & & & \\
\hline
\end{tabular}

mean and five (1-5) spot analyses; *1 - theoretical composition of kolbeckite $\mathrm{ScPO}_{4} \cdot 2 \mathrm{H}_{2} \mathrm{O}$

Empirical formulas were calculated on the basis of $6 \mathrm{O} a p f u$; $\mathrm{H}_{2} \mathrm{O}^{*}$ - water content calculated from the ideal formula $\left(\mathrm{H}_{2} \mathrm{O}=2.00\right)$.

\section{Leucophosphite $\mathrm{KFe}_{2}\left(\mathrm{PO}_{4}\right)_{2}(\mathrm{OH}) \cdot 2 \mathrm{H}_{2} \mathrm{O}$}

Common leucophosphite as one of the latest minerals in corroded cavities in phosphate accumulations has been found in samples from the Huber open pit. It typically 
forms rich crystalline aggregates or crusts up to $0.5 \mathrm{~cm}$ in size, composed of well-formed tabular crystals (Figs $63,64)$ only $0.1-1 \mathrm{~mm}$, exceptionally $3 \mathrm{~mm}$ long. Leucophosphite is colourless and translucent, light yellowish, grey or grey green and has a strong vitreous lustre. Fluorapatite, minerals of the turquoise group, pharmacosiderite, kolbeckite, whitmoreite and probable new species UNK1, UNK3, UNK6, UNK7, UNK8, UNK10 (Sejkora et al. 2006) are associated. One cavity contained K-deficient leucophosphite (designated as type b below) in yellowish crystalline aggregates (Figs 65, 66) several $\mathrm{mm}$ in size, intergrown in and overgrown on fibrous beraunite aggregates in association with UNK3 (Fig. 67). The individual tabular crystals are well-formed and similar to those of the first type decribed.

The X-ray powder data and refined unit-cell parameters (Table 22) for the two types of leucophosphite are closely similar and correspond to published data for this species and also to the theoretical pattern calculated from structural data (Dick - Zeiske 1997). For K-deficient leu-

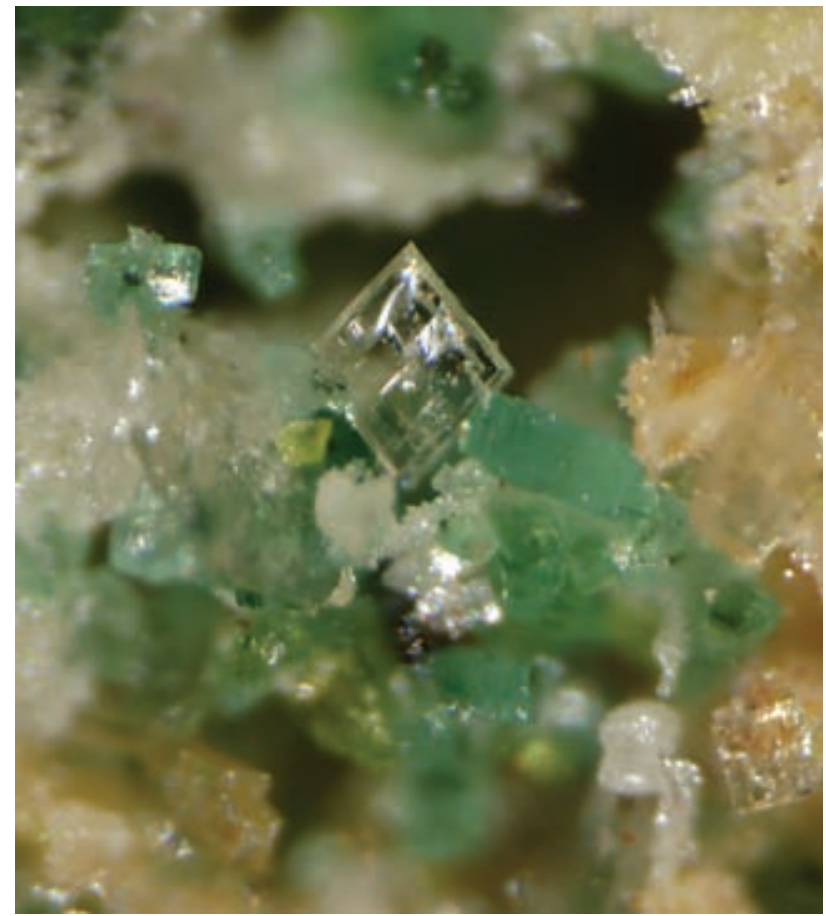

Fig. 63 Leucophosphite (a) crystal in a cavity in phoshate aggregate; Huber open pit, Krásno. Width of photo $2 \mathrm{~mm}$. Microphotography Nicon SMZ1500 by J. \& E. Sejkora.

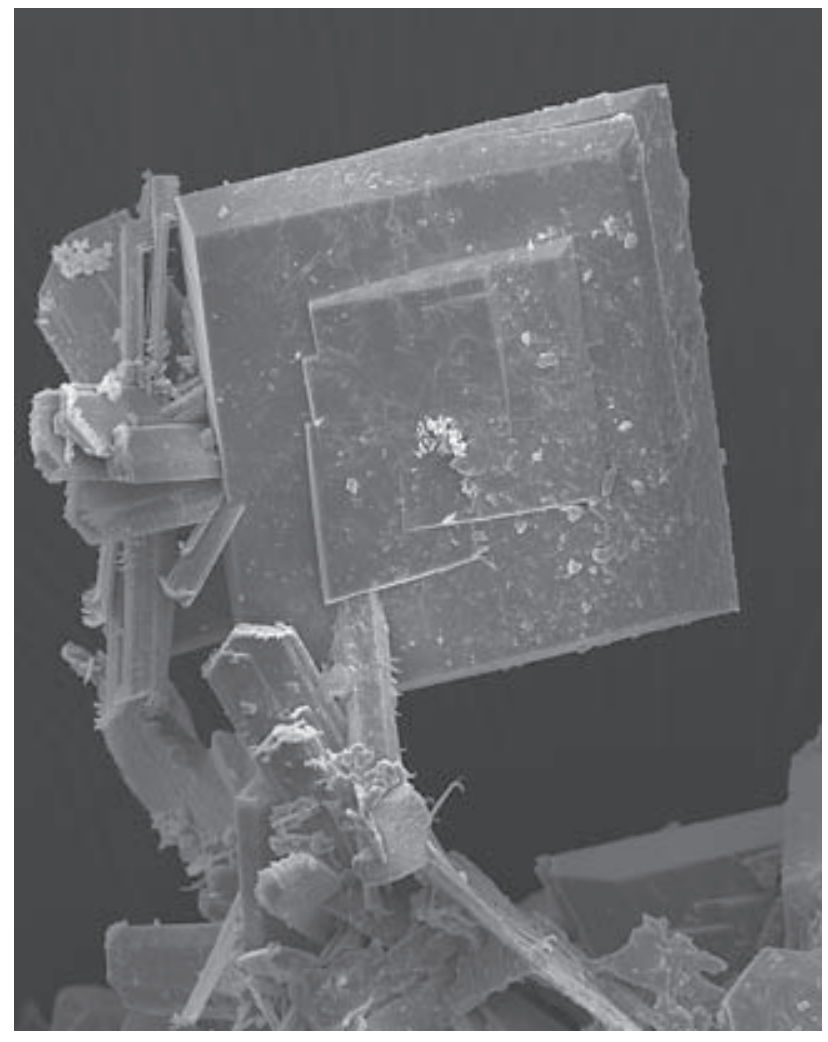

Fig. 64 Tabular leucophosphite (a) crystals; Huber open pit, Krásno. Width of photo $110 \mu \mathrm{m}$. SEM photograph by J. Sejkora.

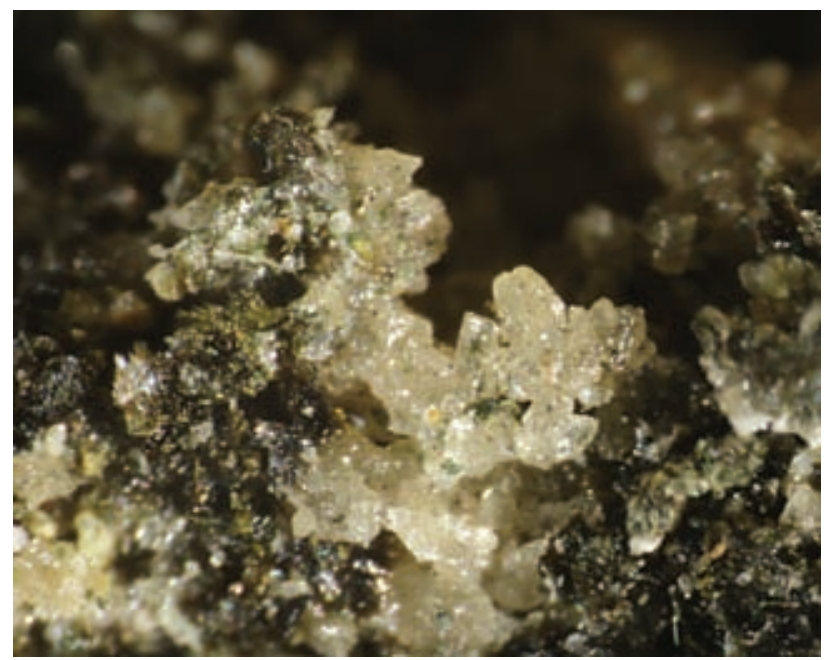

Fig. 65 Crystals of K-deficient leucosphosphite (b) on beraunite; Huber open pit, Krásno. Width of photo $2 \mathrm{~mm}$. Nicon SMZ1500 microphotography by J. \& E. Sejkora.

Table 22 Unit-cell parameters of leucophosphite (for monoclinic space group $P 2_{1} / n$ )

\begin{tabular}{|l|ccccc|}
\hline & $\begin{array}{c}\text { Krásno (a) } \\
\text { this paper }\end{array}$ & $\begin{array}{c}\text { Krásno (b) } \\
\text { this paper }\end{array}$ & $\begin{array}{c}\text { Sapucaia } \\
\text { Lindberg (1957) }\end{array}$ & $\begin{array}{c}\text { Tip Top } \\
\text { Moore (1972) }\end{array}$ & $\begin{array}{c}\text { Těškov } \\
\text { Dick - Zeiske (1997) }\end{array}$ \\
\hline $\mathrm{a}[\AA]$ & $9.770(8)$ & $9.807(5)$ & $9.73(4)$ & $9.782(9)$ & $9.758(4)$ \\
$\mathrm{b}[\AA]$ & $9.649(4)$ & $9.677(3)$ & $9.60(4)$ & $9.658(9)$ & $9.647(4)$ \\
$\mathrm{c}[\AA]$ & $9.683(7)$ & $9.684(4)$ & $9.69(4)$ & $9.751(9)$ & $9.736(4)$ \\
$\beta\left[{ }^{\circ}\right]$ & $102.47(1)$ & $102.36(1)$ & $102.3(3)$ & $102.24(1)$ & $102.50(3)$ \\
$\mathrm{V}\left[\AA^{3}\right]$ & $891.4(5)$ & $897.7(4)$ & 884.4 & 900.2 & 894.8 \\
\hline
\end{tabular}




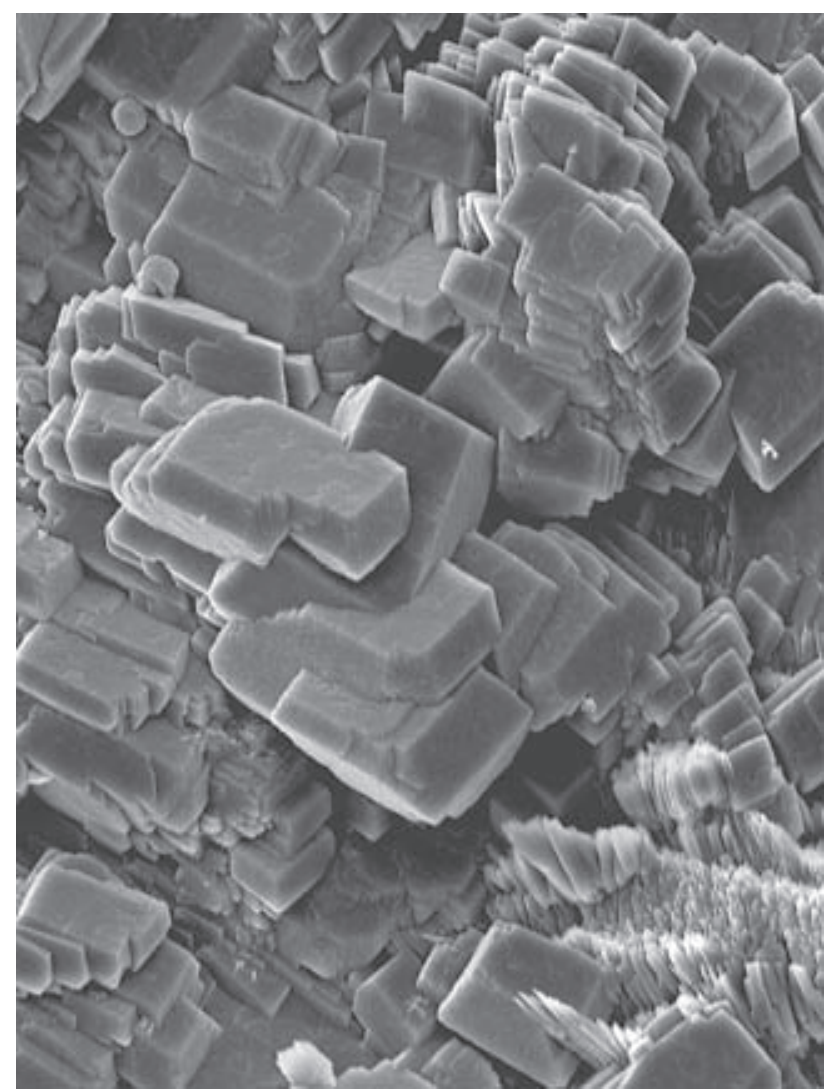

Fig. 66 Crystals of K-deficient leucophosphite (b) on fibrous beraunite; Huber open pit, Krásno. Width of photo $40 \mu \mathrm{m}$. SEM photograph by J. Sejkora.

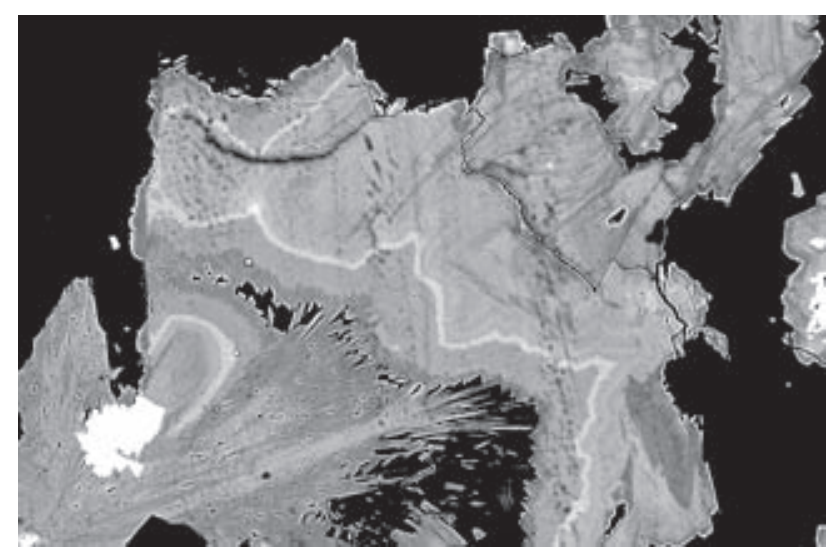

Fig. 67 Zoned crystalline aggregates of K-deficient leucophosphite (b) intergrown with aggregates of fibrous beraunite; (zoning is caused by $\mathrm{Fe} / \mathrm{Al}$ and $\mathrm{P} / \mathrm{As}$ variation, $\mathrm{K}$ content is constant). The white grains correspond to $U N K 3$. Huber open pit, Krásno. Width of photo $300 \mu \mathrm{m}$. Cameca SX100, BSE photograph by J. Sejkora and R. Škoda.

cophosphite (b) the parameter a $(9.807 \AA)$ is higher than the published data (9.73-9.78 $\AA$ ). This increase in a value does not correspond to the trends of known substitution $\left(\mathrm{K}-\mathrm{NH}_{4}, \mathrm{Fe}-\mathrm{Al}\right)$ in leucophosphite-group minerals (Marincea et al. 2002).

The ideal formula for leucophosphite-related minerals (Dick - Zeiske 1997) can be expressed as $\mathrm{M}^{1+} \mathrm{M}^{3+}{ }_{2}$
$\left(\mathrm{PO}_{4}\right)_{2}(\mathrm{OH}) .2 \mathrm{H}_{2} \mathrm{O}$. The $\mathrm{M}^{1+}$ site is filled by $\mathrm{K}$ (leucophosphite, tinsleyite), $\left(\mathrm{NH}_{4}\right)$ group (spheniscidite) and a smaller quantity of $\mathrm{Na}$. The $\mathrm{M}^{3+}$ site is dominated by $\mathrm{Fe}^{3+}$ (leucophosphite, spheniscidite) or $\mathrm{Al}^{3+}$ (tinsleyite). Quantitative chemical analyses of leucophosphite (Table 23) show that there are two varieties with different occupancy of the $\mathrm{M}^{1+}$ site in the general formula (Fig. 68). In the predominating variety (a) the site $\mathrm{M}^{1+}$ is almost completely filled by $\mathrm{K}$ ( 0.84 to 0.98 apfu $)$, accompanied by minor $\mathrm{Na}$ (max. 0.02 apfu) and deficit in $\mathrm{M}^{1+}$ site is in the range of 0.02-0.15 pfu. The less common variety (b) contains in the $\mathrm{M}^{1+}$ site only 0.48 to 0.67 apfu $\mathrm{K}$, accompanied by Na max. 0.01 apfu and a significant deficit in the range of $0.33-0.52 \mathrm{pfu}$. This deficit could be explained by the presence of $\left(\mathrm{NH}_{4}\right)^{+}$ion in place of $\mathrm{K}$, i.e., by substitution toward sphenicsidite. However, this mineral has been described only from guano beds (Wilson - Bain 1976, 1986), from phosphate concretions hosted in Miocene diatomites and diatomaceous shales (Medrano Piper 1997), and from highly fertilized soils (Dick Zeiske 1997). The possible presence of the $\left(\mathrm{NH}_{4}\right)^{+}$group in the two types of leucophosphite from Krásno was examined by infrared absorption spektroskopy (FTIR spectrophotometr Nicolet 740, KBr disk, analyst M. Novotná). However, both samples gave practically identical infrared spectra and there were no absorption bands in regions charakteristic for bond vibrations of $\left(\mathrm{NH}_{4}\right)^{+}$ groups (Farmer et al. 1974). Therefore, presence of vacancies is a probable explanation for deficiency of cations in the $\mathrm{M}^{1+}$ site. The structure of leucophosphite is characterized by position of weakly bonded $\mathrm{K}$ atoms in channels running parallel to the $b$-axis (Dick - Zeiske 1997). Some of the published analyses of leucophosphiterelated minerals also show deficit in $\mathrm{M}^{1+}$ site [leucoph-

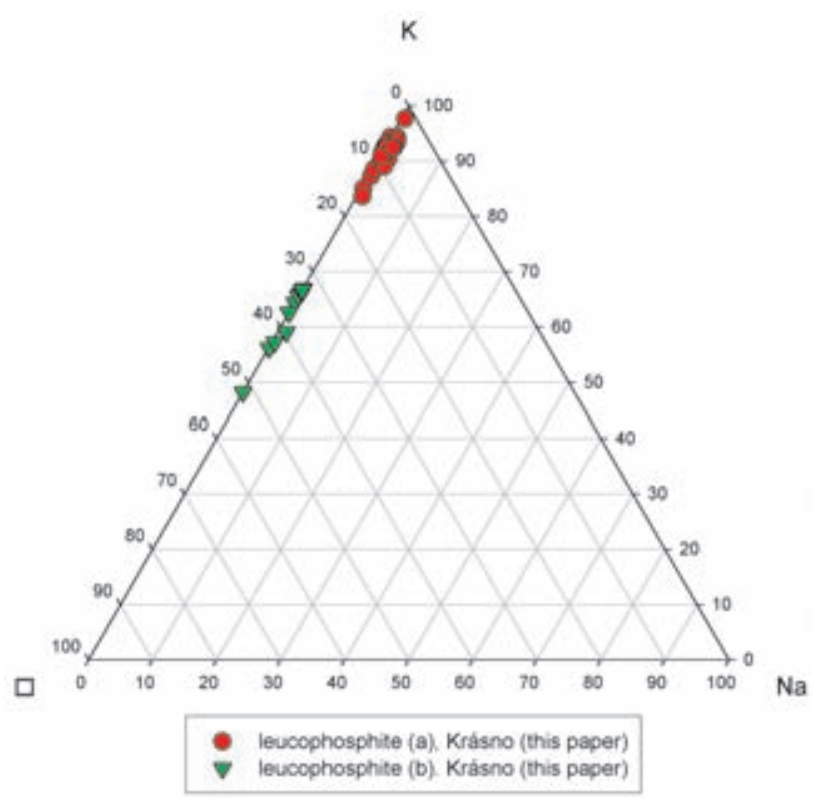

Fig. 68 Ternary plot of occupation of $\mathrm{M}^{1+}$ site (atomic ratio) in leucophosphite, Huber open pit, Krásno. $\square$ - vacancy in $\mathrm{M}^{1+}$ site. 
Table 23 Chemical composition of leucophosphite (wt. \%).

\begin{tabular}{|c|c|c|c|c|c|c|c|c|c|c|}
\hline & \multicolumn{5}{|c|}{ leucophosphite (b) - K-deficient } & \multicolumn{4}{|c|}{ leucophosphite (a) } & \multirow[b]{2}{*}{8} \\
\hline & mean & 1 & 2 & 3 & 4 & mean & 5 & 6 & 7 & \\
\hline $\mathrm{Na}_{2} \mathrm{O}$ & 0.02 & 0.00 & 0.01 & 0.01 & 0.01 & 0.05 & 0.04 & 0.09 & 0.01 & 0.11 \\
\hline $\mathrm{K}_{2} \mathrm{O}$ & 7.75 & 5.95 & 7.19 & 8.37 & 8.37 & 10.87 & 10.46 & 11.49 & 11.09 & 10.91 \\
\hline $\mathrm{CaO}$ & 0.12 & 0.31 & 0.09 & 0.12 & 0.09 & 0.15 & 0.64 & 0.05 & 0.10 & 0.00 \\
\hline $\mathrm{BaO}$ & 0.03 & 0.00 & 0.00 & 0.00 & 0.00 & 0.07 & 0.00 & 0.00 & 0.32 & 0.00 \\
\hline $\mathrm{SrO}$ & 0.00 & 0.00 & 0.00 & 0.00 & 0.00 & 0.03 & 0.11 & 0.00 & 0.00 & 0.00 \\
\hline $\mathrm{MnO}$ & 0.07 & 0.17 & 0.00 & 0.10 & 0.03 & 0.03 & 0.02 & 0.02 & 0.10 & 0.00 \\
\hline $\mathrm{PbO}$ & 0.02 & 0.12 & 0.00 & 0.04 & 0.00 & 0.03 & 0.00 & 0.06 & 0.19 & 0.07 \\
\hline $\mathrm{CuO}$ & 0.00 & & & & & 0.35 & 0.46 & 0.00 & 0.04 & 0.46 \\
\hline $\mathrm{ZnO}$ & 0.56 & 0.82 & 0.34 & 0.68 & 0.32 & 0.37 & 0.24 & 0.13 & 0.30 & 0.12 \\
\hline $\mathrm{Al}_{2} \mathrm{O}_{3}$ & 3.82 & 1.35 & 5.56 & 3.31 & 6.31 & 3.43 & 3.56 & 5.88 & 4.50 & 1.95 \\
\hline $\mathrm{Fe}_{2} \mathrm{O}_{3}$ & 37.23 & 39.18 & 34.35 & 38.11 & 33.97 & 33.21 & 32.16 & 30.93 & 32.14 & 36.32 \\
\hline $\mathrm{SiO}_{2}$ & 0.02 & 0.03 & 0.00 & 0.00 & 0.00 & 0.01 & 0.00 & 0.02 & 0.02 & 0.03 \\
\hline $\mathrm{TiO}_{2}$ & 0.22 & 0.03 & 0.51 & 0.20 & 0.34 & 0.25 & 0.11 & 0.17 & 0.21 & 0.42 \\
\hline $\mathrm{As}_{2} \mathrm{O}_{5}$ & 1.17 & 1.80 & 0.42 & 1.00 & 0.29 & 0.76 & 2.94 & 0.10 & 0.34 & 0.76 \\
\hline $\mathrm{P}_{2} \mathrm{O}_{5}$ & 37.05 & 35.95 & 38.30 & 37.04 & 37.59 & 35.36 & 35.13 & 36.55 & 36.10 & 35.06 \\
\hline $\mathrm{SO}_{3}$ & 0.02 & 0.08 & 0.00 & 0.03 & 0.04 & 0.06 & 0.15 & 0.09 & 0.16 & 0.00 \\
\hline $\mathrm{H}_{2} \mathrm{O}^{*}$ & 12.02 & 11.50 & 11.95 & 12.12 & 12.36 & 11.74 & 11.20 & 11.98 & 11.75 & 11.92 \\
\hline total & 100.11 & 97.29 & 98.721 & 101.13 & 99.70 & 96.79 & 97.20 & 97.55 & 97.36 & 98.12 \\
\hline $\mathrm{Na}$ & 0.002 & 0.000 & 0.001 & 0.001 & 0.001 & 0.007 & 0.004 & 0.011 & 0.001 & 0.014 \\
\hline K & 0.618 & 0.483 & 0.562 & 0.670 & 0.667 & 0.913 & 0.850 & 0.943 & 0.917 & 0.924 \\
\hline$\square$ & 0.380 & 0.517 & 0.437 & 0.329 & 0.333 & 0.081 & 0.146 & 0.046 & 0.082 & 0.063 \\
\hline total $\mathrm{M}^{1+}$ site & 1.000 & 1.000 & 1.000 & 1.000 & 1.000 & 1.000 & 1.000 & 1.000 & 1.000 & 1.000 \\
\hline $\mathrm{Ca}$ & 0.008 & 0.021 & 0.006 & 0.008 & 0.006 & 0.010 & 0.044 & 0.003 & 0.007 & 0.000 \\
\hline $\mathrm{Ba}$ & 0.001 & 0.000 & 0.000 & 0.000 & 0.000 & 0.002 & 0.000 & 0.000 & 0.008 & 0.000 \\
\hline $\mathrm{Sr}$ & 0.000 & 0.000 & 0.000 & 0.000 & 0.000 & 0.001 & 0.004 & 0.000 & 0.000 & 0.000 \\
\hline $\mathrm{Pb}$ & 0.000 & 0.002 & 0.000 & 0.001 & 0.000 & 0.001 & 0.000 & 0.001 & 0.003 & 0.001 \\
\hline $\mathrm{Cu}$ & 0.000 & 0.000 & 0.000 & 0.000 & 0.000 & 0.018 & 0.022 & 0.000 & 0.002 & 0.023 \\
\hline $\mathrm{Mn}$ & 0.004 & 0.009 & 0.000 & 0.005 & 0.001 & 0.002 & 0.001 & 0.001 & 0.005 & 0.000 \\
\hline $\mathrm{Zn}$ & 0.026 & 0.038 & 0.015 & 0.031 & 0.015 & 0.018 & 0.011 & 0.006 & 0.015 & 0.006 \\
\hline $\mathrm{Al}$ & 0.281 & 0.101 & 0.401 & 0.245 & 0.464 & 0.266 & 0.267 & 0.446 & 0.344 & 0.153 \\
\hline $\mathrm{Fe}^{3+}$ & 1.750 & 1.874 & 1.583 & 1.798 & 1.597 & 1.645 & 1.542 & 1.498 & 1.567 & 1.815 \\
\hline $\mathrm{Ti}^{4+}$ & 0.010 & 0.002 & 0.024 & 0.009 & 0.016 & 0.012 & 0.005 & 0.008 & 0.010 & 0.021 \\
\hline total $\mathrm{M}^{3+}$ sites & 2.080 & 2.048 & 2.030 & 2.098 & 2.099 & 1.976 & 1.896 & 1.963 & 1.961 & 2.019 \\
\hline $\mathrm{Si}^{4+}$ & 0.001 & 0.002 & 0.000 & 0.000 & 0.000 & 0.001 & 0.000 & 0.001 & 0.001 & 0.002 \\
\hline $\mathrm{As}^{5+}$ & 0.038 & 0.060 & 0.013 & 0.033 & 0.010 & 0.026 & 0.098 & 0.003 & 0.011 & 0.026 \\
\hline $\mathrm{P}^{5+}$ & 1.959 & 1.935 & 1.987 & 1.966 & 1.989 & 1.970 & 1.895 & 1.991 & 1.980 & 1.971 \\
\hline $\mathrm{S}^{6+}$ & 0.001 & 0.004 & 0.000 & 0.001 & 0.002 & 0.003 & 0.007 & 0.004 & 0.008 & 0.000 \\
\hline total anion sites & 2.000 & 2.000 & 2.000 & 2.000 & 2.000 & 2.000 & 2.000 & 2.000 & 2.000 & 2.000 \\
\hline $\mathrm{H}$ & 4.827 & 4.553 & 4.653 & 4.933 & 4.961 & 4.818 & 4.474 & 4.849 & 4.780 & 4.989 \\
\hline $\mathrm{OH}$ & 0.832 & 0.559 & 0.655 & 0.931 & 0.961 & 0.809 & 0.474 & 0.844 & 0.777 & 0.983 \\
\hline $\mathrm{H}_{2} \mathrm{O}$ & 1.998 & 1.997 & 1.999 & 2.001 & 2.000 & 2.004 & 2.000 & 2.003 & 2.001 & 2.003 \\
\hline
\end{tabular}

1-4 - representative spot analyses of K-deficient leucophosphite (b); 5-8 - representative spot analyses of leucophosphite (a). $\mathrm{H}_{2} \mathrm{O}^{*}$ calculated from the theoretical content of $\mathrm{H}_{2} \mathrm{O}=2.00$ and charge balance; empirical formulas were calculated on the basis of $(\mathrm{P}+\mathrm{As}+\mathrm{S}+\mathrm{Si})=2$.

osphite: 0.27 pfu - Lottermoser - Lu (1997); tinsleyite: 0.11 pfu - Dunn et al. (1984) and 0.06-0.14 pfu-Marincea et al. (2002)].

Because contents of other elements do not correlate with the magnitude of deficit (vacancy) in the $\mathrm{M}^{1+}$ site, it is possible to discuss occupancy of other structure sites for both varieties of leucophosphite. The $\mathrm{M}^{3+}$ site is always dominated by $\mathrm{Fe}^{3+}$ (1.49-1.98 apfu) over Al (0.050.46 apfu); the $\mathrm{Al}$ content corresponding to tinsleyite component varies in the range c. 3-23 mol. \% (Fig. 69). The contents of $\mathrm{Ca}, \mathrm{Ba}, \mathrm{Sr}, \mathrm{Pb}, \mathrm{Mn}$ and $\mathrm{Zn}$ are irregular and relatively small (max. $0.04 a p f u)$. The total for this position is 1.90 to $2.13 \mathrm{apfu}$. The tetrahedral sites of the anion group (Fig. 70) contain predominating P (1.85-1.99 apfu), with As contents 0-0.14 apfu and minor S and Si (max. 0.01 apfu).

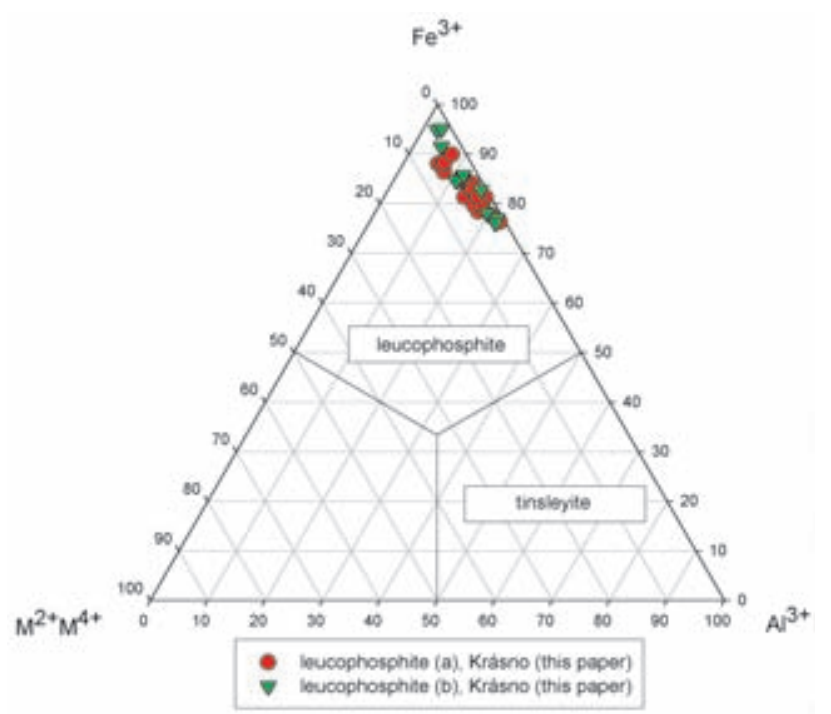

Fig. 69 Ternary plot of occupation of the $\mathrm{M}^{3+}$ sites (atomic ratio) in leucophosphite, Huber open pit, Krásno. 


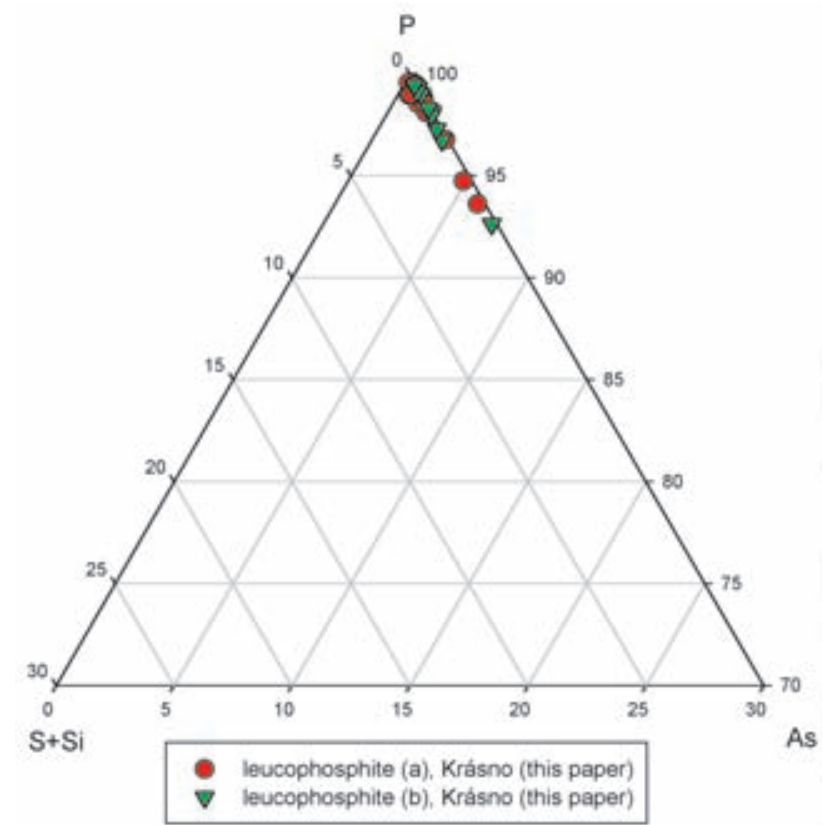

Fig. 70 Part of ternary plot of occupation of the anion sites (in molar unit) in leucophosphite. Huber open pit, Krásno.

The empirical formula for the predominating type (a) of leucophosphite (average of 23 spot analyses) on the basis of $(\mathrm{P}+\mathrm{As}+\mathrm{S}+\mathrm{Si})=2$ is $\left(\mathrm{K}_{0.91} \mathrm{Na}_{0.01}\right)_{\Sigma 0.92}\left(\mathrm{Fe}_{1.65} \mathrm{Al}_{0.27}\right.$ $\left.\mathrm{Cu}_{0.02} \mathrm{Zn}_{0.02} \mathrm{Ti}_{0.01}\right)_{\Sigma 1.97}\left[\left(\mathrm{PO}_{4}\right)_{1.97}\left(\mathrm{AsO}_{4}\right)_{0.03}\right]_{\Sigma 2.00}(\mathrm{OH})_{0.81}$. $2.00 \mathrm{H}_{2} \mathrm{O}$, for the rare $\mathrm{K}$-deficient leukophosphite (b) (average of 11 spot analyses) the formula is $\mathrm{K}_{0.62}\left(\mathrm{Fe}_{1.75}\right.$ $\left.\mathrm{Al}_{0.28} \mathrm{Zn}_{0.03} \mathrm{Ca}_{0.01} \mathrm{Ti}_{0.01}\right)_{\Sigma 2.08}\left[\left(\mathrm{PO}_{4}\right)_{1.96}\left(\mathrm{AsO}_{4}\right)_{0.04}\right]_{\Sigma 2.00}(\mathrm{OH})_{0.83}$ $.2 .00 \mathrm{H}_{2} \mathrm{O}$.

\section{Morinite $\mathrm{NaCa}_{2} \mathrm{Al}_{2}\left(\mathrm{PO}_{4}\right)_{2} \mathrm{~F}_{4}(\mathrm{OH})$. $2 \mathrm{H}_{2} \mathrm{O}$}

Morinite has been found in several samples of phosphate accumulations collected at the $5^{\text {th }}$ level of the Huber shaft. It forms whitish and light pink irregular granular aggregates up to $5 \mathrm{~mm}$ across, with a weak pearly to vitreous lustre (Fig. 71). Closely associated minerals include frondelite, UNK9, beraunite, fluorapatite, bluish phosphosiderite (Fig. 72) and rare purple red strengite. Morinite belongs to the youngest minerals in this association.

Morinite was identified by X-ray powder diffraction data as a phase predominating in a mixture with small quantities of strengite and fluorapatite. The refined unitcell parameters of morinite (Table 24) closely correspond to data published for this mineral. The general chemical formula of morinite can be presented as $\mathrm{A}^{+} \mathrm{B}_{2}^{2+} \mathrm{C}^{3+}{ }_{2}\left(\mathrm{TO}_{4}\right)_{2} \mathrm{~F}_{4}(\mathrm{OH}) \cdot 2 \mathrm{H}_{2} \mathrm{O}$, where $\mathrm{A}=\mathrm{Na}, \mathrm{B}=\mathrm{Ca}$, $\mathrm{C}=\mathrm{Al}$ and $\mathrm{T}=\mathrm{P}$ (Hawthorne 1979). The chemical composition of morinite from Krásno (Table 25) corresponds to the above formula; minor differences are noted in the content of $\mathrm{F}$ and partly in presence of $\mathrm{Fe}$ and $\mathrm{Mn}$. In the $A$-site, Na strongly predominates above $\mathrm{K}$ content. The

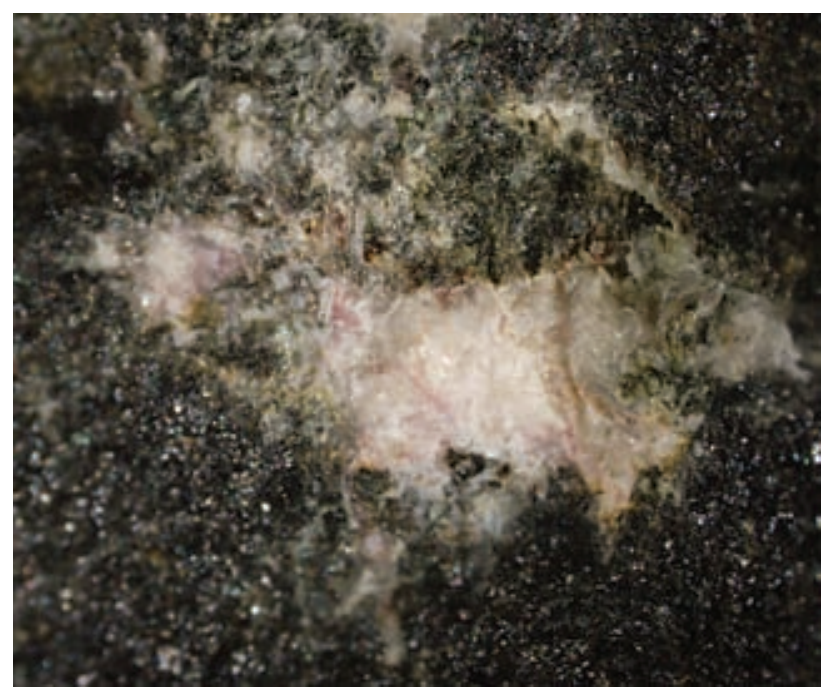

Fig. 71 Light pink morinite aggregates intergrown with dark frondelite. $5^{\text {th }}$ level of the Huber shaft, Krásno. Width of photo $5 \mathrm{~mm}$. Nicon SMZ1500 microphotography by J.\&E. Sejkora.

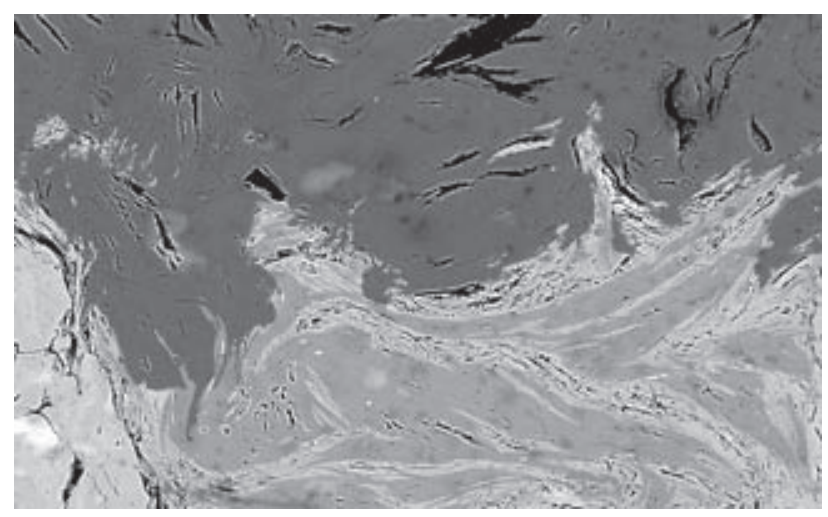

Fig. 72 Morinite (dark) intergrown with fluorapatite (light fibrous and compact) and phosphosiderite (medium grey). $5^{\text {th }}$ level of the Huber shaft, Krásno. Width of photo $400 \mu \mathrm{m}$. Cameca SX100, BSE photograph by J. Sejkora and R. Škoda.

Table 24 Unit-cell parameters of morinite (for monoclinic space group $P 2_{1} / m$ )

\begin{tabular}{|l|cc|}
\hline & this paper & Hawthorne (1979) \\
\hline $\mathrm{a}[\AA]$ & $9.465(4)$ & $9.454(3)$ \\
$\mathrm{b}[\AA]$ & $10.691(5)$ & $10.692(4)$ \\
$\mathrm{c}[\AA]$ & $5.459(2)$ & $5.444(2)$ \\
$\beta\left[{ }^{\circ}\right]$ & $105.58(3)$ & $105.46(2)$ \\
$\mathrm{V}\left[\AA^{3}\right]$ & $532.1(4)$ & 530.4 \\
\hline
\end{tabular}

observed deficit in this site $(0.02-0.20 \mathrm{pfu})$ may correspond to vacancy. In the $B$-site (Fig. 73), dominating $\mathrm{Ca}$ is accompanied by $\mathrm{Fe}$ (up to 0.16 ) and $\mathrm{Mg}$ (to $0.16 \mathrm{apfu}$ ), which positively correlate with $\mathrm{F}$ content (Fig. 74). A presence of $\mathrm{Fe}$ in the $C$-site, seemingly indicated by lower 
totals in this position (1.83-2.01 apfu), is not probable with regard to the absence of $\mathrm{Fe} / \mathrm{Al}$ correlation. Phosphorus predominates in the tetrahedral sites, minor and irregular contents of $\mathrm{Si}, \mathrm{S}$ and As attain only 0.01-0.02 apfu. Fluorine contents (Fig. 75) correspond to entry of this element (up to $0.44 \mathrm{apfu}$ ) in the $(\mathrm{OH})$-site. The published chemical analyses of morinite from various localities (Palache et al. 1951; Ficher - Runner 1958; Fischer 1960) do not show such high F contents. The empirical formulas for representative spot analyses of morinte from Krásno, based on $(\mathrm{P}+\mathrm{As}+\mathrm{S}+\mathrm{Si})=2$, are given in Table 25.

Table 25 Chemical composition of morinite (in wt. \%)

\begin{tabular}{|c|c|c|c|c|c|c|c|}
\hline & 1 & 2 & 3 & 4 & 5 & 6 & 7 \\
\hline $\mathrm{Na}_{2} \mathrm{O}$ & 5.40 & 6.01 & 5.02 & 5.75 & 6.27 & 6.28 & 5.12 \\
\hline $\mathrm{K}_{2} \mathrm{O}$ & 0.02 & 0.01 & 0.01 & 0.08 & 0.01 & 0.02 & 0.01 \\
\hline $\mathrm{CaO}$ & 21.82 & 21.70 & 21.83 & 22.84 & 22.84 & 23.29 & 23.02 \\
\hline $\mathrm{SrO}$ & 0.00 & 0.11 & 0.02 & 0.00 & 0.00 & 0.00 & 0.00 \\
\hline $\mathrm{BaO}$ & 0.17 & 0.06 & 0.00 & 0.00 & 0.02 & 0.00 & 0.07 \\
\hline $\mathrm{MgO}$ & 1.35 & 0.80 & 0.27 & 0.15 & 0.09 & 0.15 & 0.21 \\
\hline $\mathrm{MnO}$ & 0.78 & 0.65 & 0.34 & 0.26 & 0.10 & 0.18 & 0.20 \\
\hline $\mathrm{FeO}$ & 0.99 & 1.32 & 2.35 & 0.57 & 0.35 & 0.32 & 0.32 \\
\hline $\mathrm{ZnO}$ & na & 0.12 & 0.16 & 0.03 & 0.06 & 0.00 & 0.19 \\
\hline $\mathrm{PbO}$ & 0.02 & 0.08 & 0.02 & 0.01 & 0.00 & 0.00 & 0.08 \\
\hline $\mathrm{Al}_{2} \mathrm{O}_{3}$ & 19.14 & 20.30 & 20.26 & 20.22 & 20.60 & 20.40 & 21.27 \\
\hline $\mathrm{TiO}_{2}$ & 0.00 & 0.03 & 0.09 & 0.05 & 0.01 & 0.03 & 0.01 \\
\hline $\mathrm{SiO}_{2}$ & 0.00 & 0.00 & 0.00 & 0.26 & 0.03 & 0.04 & 0.04 \\
\hline $\mathrm{P}_{2} \mathrm{O}_{5}^{2}$ & 28.97 & 29.10 & 28.85 & 28.81 & 29.28 & 29.50 & 29.41 \\
\hline $\mathrm{As}_{2} \mathrm{O}_{5}$ & 0.01 & 0.21 & 0.00 & 0.00 & 0.00 & 0.00 & 0.00 \\
\hline $\mathrm{SO}_{3}$ & 0.14 & 0.21 & 0.01 & 0.16 & 0.01 & 0.24 & 0.06 \\
\hline $\mathrm{Cl}$ & 0.01 & 0.01 & 0.00 & 0.02 & 0.00 & 0.01 & 0.00 \\
\hline $\mathrm{F}$ & 17.30 & 16.42 & 15.87 & 15.29 & 14.89 & 14.97 & 15.17 \\
\hline $\mathrm{O}=\mathrm{F}, \mathrm{Cl}$ & -7.28 & -6.92 & -6.68 & -6.44 & -6.27 & -6.30 & -6.39 \\
\hline$* \mathrm{H}_{2} \mathrm{O}(\mathrm{C}$ & 0.91 & 1.52 & 1.62 & 1.93 & 2.19 & 2.25 & 2.13 \\
\hline$* \mathrm{H}_{2} \mathrm{O}$ & 7.29 & 7.44 & 7.31 & 7.34 & 7.40 & 7.47 & 7.46 \\
\hline total & 97.02 & 99.17 & 97.31 & 97.31 & 97.88 & 98.93 & 98.37 \\
\hline $\mathrm{Na}^{+}$ & 0.850 & 0.935 & 0.796 & 0.900 & 0.980 & 0.966 & 0.795 \\
\hline $\mathrm{K}^{+}$ & 0.002 & 0.001 & 0.001 & 0.008 & 0.001 & 0.002 & 0.001 \\
\hline subtotal & 0.852 & 0.937 & 0.797 & 0.908 & 0.981 & 0.969 & 0.796 \\
\hline $\mathrm{Ca}^{2+}$ & 1.898 & 1.867 & 1.914 & 1.976 & 1.972 & 1.982 & 1.974 \\
\hline $\mathrm{Sr}^{2+}$ & 0.000 & 0.005 & 0.001 & 0.000 & 0.000 & 0.000 & 0.000 \\
\hline $\mathrm{Ba}^{2+}$ & 0.005 & 0.002 & 0.000 & 0.000 & 0.001 & 0.000 & 0.002 \\
\hline $\mathrm{Mg}^{2+}$ & 0.164 & 0.096 & 0.033 & 0.018 & 0.011 & 0.018 & 0.025 \\
\hline $\mathrm{Mn}^{2+}$ & 0.053 & 0.044 & 0.024 & 0.018 & 0.007 & 0.012 & 0.013 \\
\hline $\mathrm{Fe}^{2+}$ & 0.067 & 0.089 & 0.161 & 0.038 & 0.024 & 0.021 & 0.021 \\
\hline $\mathrm{Zn}^{2+}$ & 0.000 & 0.007 & 0.010 & 0.002 & 0.003 & 0.000 & 0.011 \\
\hline $\mathrm{Pb}^{2+}$ & 0.001 & 0.002 & 0.000 & 0.000 & 0.000 & 0.000 & 0.002 \\
\hline $\mathrm{Al}^{3+}$ & 1.832 & 1.922 & 1.954 & 1.924 & 1.957 & 1.910 & 2.006 \\
\hline $\mathrm{Ti}^{4+}$ & 0.000 & 0.002 & 0.005 & 0.003 & 0.000 & 0.002 & 0.000 \\
\hline subtotal & 4.019 & 4.035 & 4.102 & 3.979 & 3.975 & 3.945 & 4.056 \\
\hline $\mathrm{Si}^{4+}$ & 0.000 & 0.000 & 0.000 & 0.021 & 0.002 & 0.003 & 0.003 \\
\hline $\mathrm{P}^{5+}$ & 1.991 & 1.979 & 1.999 & 1.969 & 1.998 & 1.983 & 1.993 \\
\hline $\mathrm{As}^{5+}$ & 0.001 & 0.009 & 0.000 & 0.000 & 0.000 & 0.000 & 0.000 \\
\hline $\mathrm{S}^{6+}$ & 0.008 & 0.012 & 0.001 & 0.009 & 0.000 & 0.014 & 0.004 \\
\hline subtotal & 2.000 & 2.000 & 2.000 & 2.000 & 2.000 & 2.000 & 2.000 \\
\hline $\mathrm{F}^{-}$ & 4.441 & 4.171 & 4.107 & 3.905 & 3.796 & 3.759 & 3.840 \\
\hline $\mathrm{Cl}^{-}$ & 0.001 & 0.001 & 0.000 & 0.003 & 0.000 & 0.001 & 0.000 \\
\hline$* \mathrm{OH}^{-}$ & 0.287 & 0.771 & 0.859 & 0.875 & 1.091 & 1.023 & 1.075 \\
\hline subtotal & 4.730 & 4.944 & 4.966 & 4.784 & 4.887 & 4.783 & 4.915 \\
\hline$* \mathrm{H}_{2} \mathrm{O}$ & 2 & 2 & 2 & 2 & 2 & 2 & 2 \\
\hline
\end{tabular}

1-7 - spot analyses of morinite from Krásno; $\mathrm{H}_{2} \mathrm{O}^{*}$ and $(\mathrm{OH})^{*}$ calculated from the theoretical content of $\mathrm{H}_{2} \mathrm{O}=2.00$ and charge balance; empirical formulas were calculated on the basis of $(\mathrm{P}+\mathrm{As}+\mathrm{S}+\mathrm{Si})=2$.

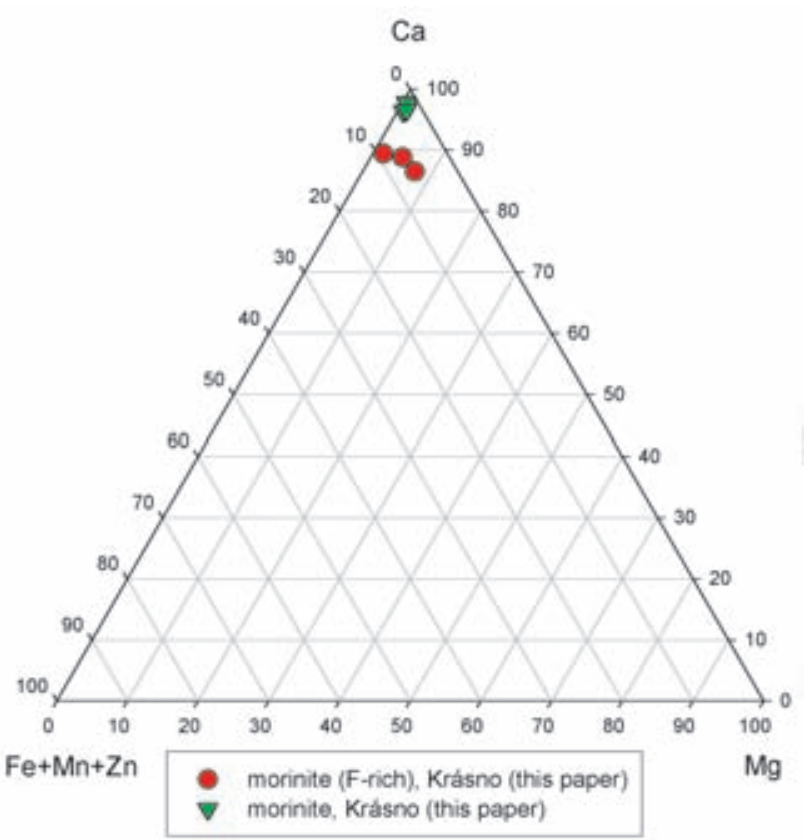

Fig. 73 Ternary plot of the $B^{2+}$-sites occupancy (atomic ratio) in morinite. $5^{\text {th }}$ level of the Huber shaft, Krásno.

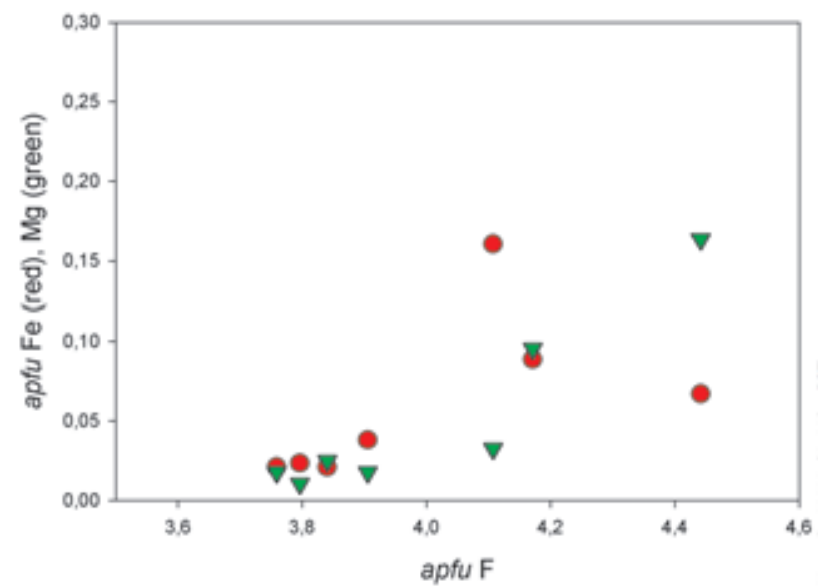

Fig. 74 A plot of apfu $\mathrm{F} v s$. apfu $\mathrm{Fe}$ and $\mathrm{Mg}$ for morinite from the $5^{\text {th }}$ level of the Huber shaft, Krásno.

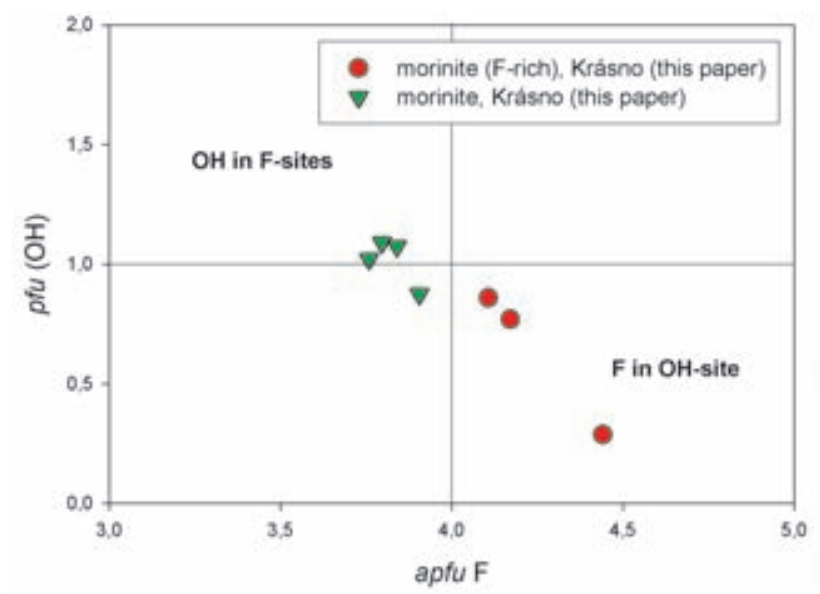

Fig. 75 A plot of apfu F vs. pfu $(\mathrm{OH})$ in $F, O H$-sites for morinite from the $5^{\text {th }}$ level of the Huber shaft, Krásno. 
Natrodufrénite $\mathrm{NaFe}^{2+} \mathrm{Fe}^{3+}{ }_{5}\left(\mathrm{PO}_{4}\right)_{4}(\mathrm{OH})_{6} \cdot 2 \mathrm{H}_{2} \mathrm{O}$ Mn-rich dufrénite $(\mathrm{o}, \mathrm{Na}, \mathrm{Ca}) \mathrm{Mn}^{2+} \mathrm{Fe}^{3+}{ }_{5}\left(\mathrm{PO}_{4}\right)_{4}(\mathrm{OH})_{6}$. $2 \mathrm{H}_{2} \mathrm{O}$

Dufrénite-related minerals of microscopic size have been found only in several specimens of strongly altered phosphate accumulation collected at the $5^{\text {th }}$ level of the $\mathrm{Hu}-$ ber shaft. Relatively more abundant natrodufrénite forms irregular aggregates, up to $100 \mu \mathrm{m}$ long, intergrown typically with frondelite and $U N K 9$, in close association with fluorapatite, Mn-rich dufrénite, fluorite and K-Mn oxides. The rare Mn-rich dufrénite forms fibrous to radiating aggregates (Fig. 76), up to $200 \mu \mathrm{m}$ across, in close association with fluorite, natrodufrénite, UNK9, phosphosiderite and beraunite.

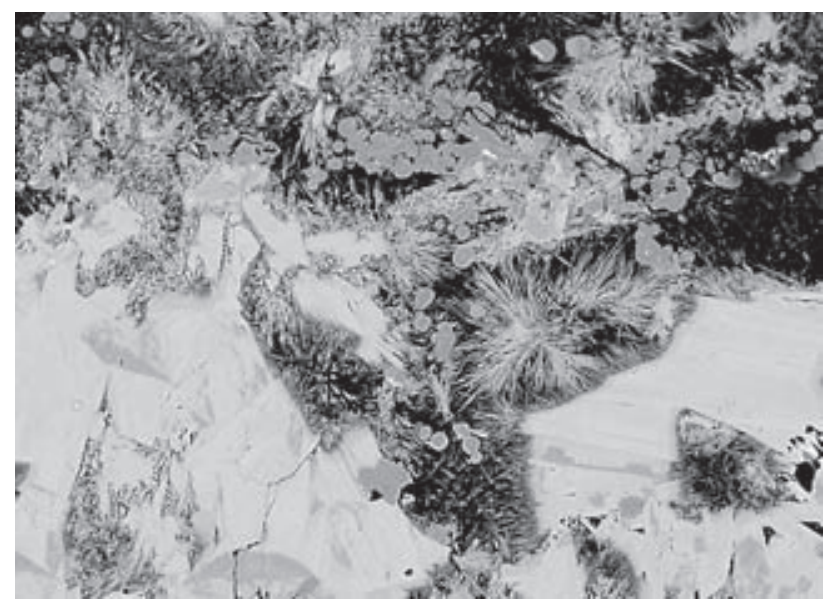

Fig. 76 Compact aggregate composed of natrodufrénite (darker) and UNK9 (lighter parts); the rich acicular aggregates are Mn-rich dufrénite, grey spheroidal aggregates are fluorite. $5^{\text {th }}$ level of the Huber shaft, Krásno. Width of photo $400 \mu \mathrm{m}$. Cameca SX100, BSE photograph by J. Sejkora and R. Škoda.

Because of the small size of natrodufrénite and Mnrich dufrénite aggregates the minerals were confirmed only by electron microprobe (Table 26). The relatively low totals of Mn-rich dufrénite analyses are probably due to the very finely fibrous character of the analyzed samples. The general formula of dufrénite-related minerals can be presented as $\mathrm{ABC}_{5}\left(\mathrm{PO}_{4}\right)_{4}(\mathrm{OH})_{6} .2 \mathrm{H}_{2} \mathrm{O}$, with $\mathrm{Na}$, $\mathrm{K}, \mathrm{Ca}$ and vacancies in the $A$-site; $B$-site is occupied by $\mathrm{M}^{2+}$ elements such as $\mathrm{Fe}, \mathrm{Mn}, \mathrm{Mg}, \mathrm{Mn}$ and $\mathrm{Zn}$ and $\mathrm{C}$-site is filled dominantly by $\mathrm{Fe}^{3+}$ or $\mathrm{Al}^{3+}$ (Fontan et al. 1982; Selway et al. 1997; Anthony et al. 2000). At present, natrodufrénite $\left(\mathrm{A}=\mathrm{Na}, \mathrm{B}=\mathrm{Fe}^{2+}, \mathrm{C}=\mathrm{Fe}^{3+}\right)$, dufrénite $\left(\mathrm{A}=\right.$ vacancy and $\left.\mathrm{Ca}, \mathrm{B}=\mathrm{Fe}^{2+}, \mathrm{C}=\mathrm{Fe}^{3+}\right)$ and burangaite $\left(\mathrm{A}=\mathrm{Na}, \mathrm{B}=\mathrm{Fe}^{2+}, \mathrm{C}=\mathrm{Al}^{3+}\right)$ are the valid mineral species in this group.

In the studied natrodufrénite from Krásno, $\mathrm{Na}(0.65-$ 0.98 apfu) predominates over $\mathrm{Ca}(0.12-0.23 \mathrm{apfu})$ in the $A$-site. This composition corresponds to the data published for natrodufrénite and burangaite (Fig. 77). In the studied Mn-rich dufrénite, Ca (0.07-0.10 apfu) and $\mathrm{Na}$ contents (0.04-0.32 apfu) are low and the site is domi- nantly vacant $(0.57-0.88 p f u)$. The $B$-site in samples from Krásno is characterized by unusually high Mn content (Fig. 78), 0.27-0.41 apfu in natrodufrénite (accompanied by $0.36-0.56$ apfu Fe and 0.17-0.23 apfu Mg), and 0.780.95 apfu Mn in Mn-rich dufrénite (with up to 0.17 apfu Fe and up to 0.07 apfu $\mathrm{Zn}$ ). Formally, the studied material could be considered as new mineral species - Mn analogue of dufrénite and natrodufrénite. However, on the basis of obtained analyses and published data it is not possible to exclude the possibility that $\mathrm{Mn}$ enters the $C$-site of crystal structure. In the $C$-site of both phases from Krásno (Fig. 79) $\mathrm{Fe}^{3+}$ (4.43-5.28 apfu) strongly pre-

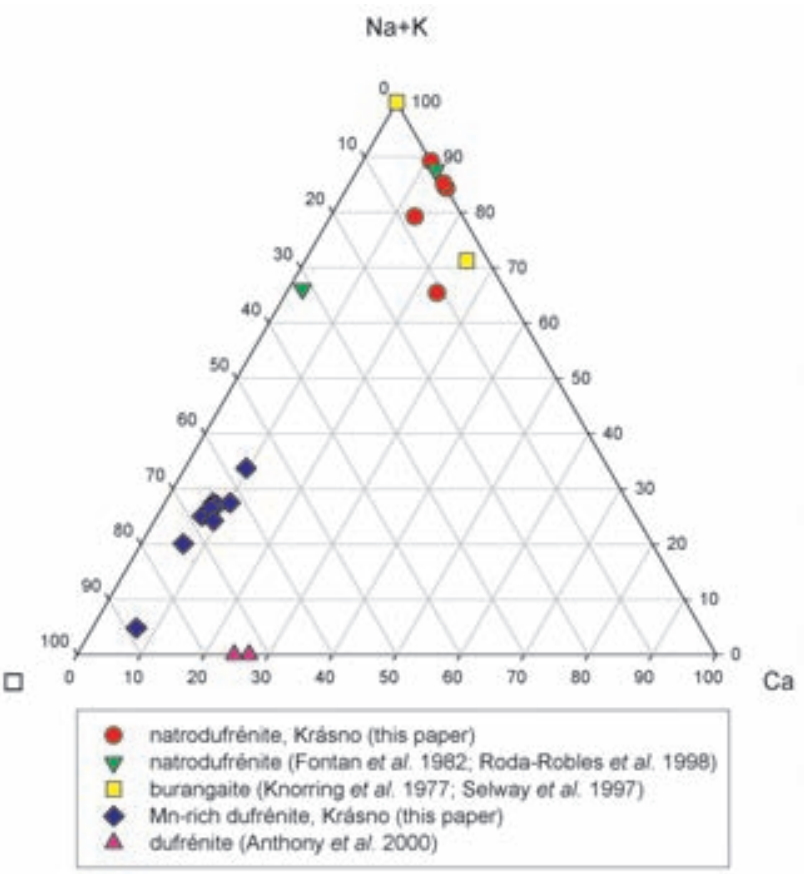

Fig. 77 Ternary plot of $A$-site occupancy (atomic ratio) in dufréniterelated minerals. $\square$ - vacancy in $A$-site.

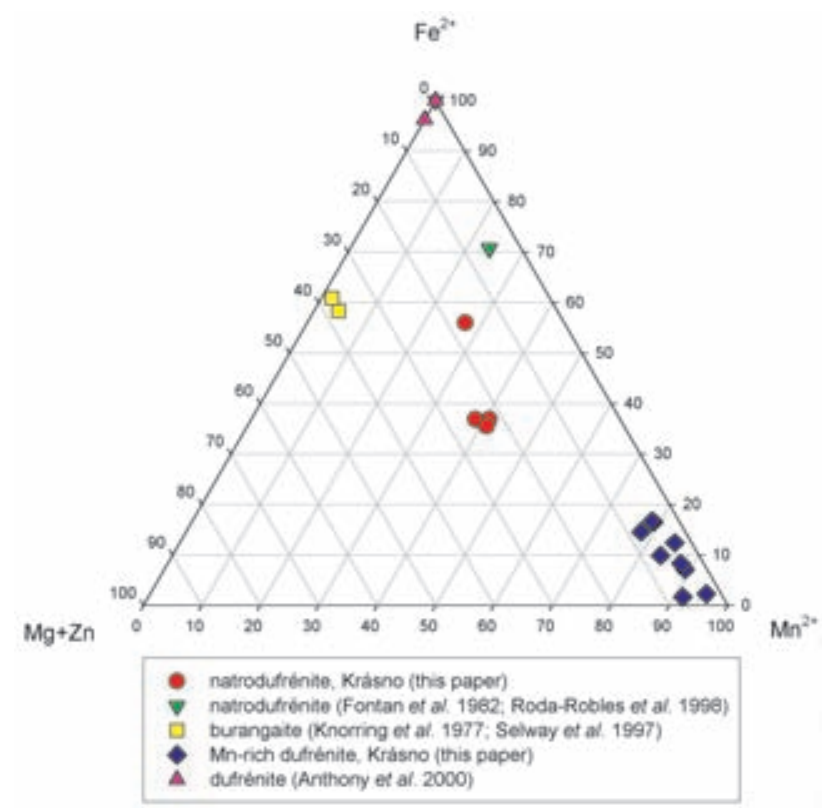

Fig. 78 Ternary plot of occupation of $B$-site (in molar unit) in dufréniterelated minerals. 
Table 26 Chemical composition of natrodufrénite and Mn-rich dufrénite (in wt. \%)

\begin{tabular}{|c|c|c|c|c|c|c|c|c|}
\hline & \multicolumn{4}{|c|}{ natrodufrénite } & \multicolumn{4}{|c|}{ Mn-rich dufrénite } \\
\hline & 1 & 2 & 3 & 4 & 5 & 6 & 7 & 8 \\
\hline $\mathrm{Na}_{2} \mathrm{O}$ & 2.98 & 2.33 & 3.08 & 3.52 & 0.78 & 0.66 & 0.16 & 0.76 \\
\hline $\mathrm{K}_{2} \mathrm{O}$ & 0.01 & 0.00 & 0.00 & 0.00 & 0.05 & 0.05 & 0.02 & 0.07 \\
\hline $\mathrm{CaO}$ & 1.03 & 1.52 & 1.03 & 0.77 & 0.49 & 0.41 & 0.44 & 0.55 \\
\hline $\mathrm{FeO}^{*}$ & 3.36 & 4.62 & 3.06 & 2.95 & 0.79 & 1.33 & 1.18 & 0.13 \\
\hline $\mathrm{BaO}$ & 0.00 & 0.00 & 0.00 & 0.00 & 0.06 & 0.13 & 0.17 & 0.04 \\
\hline $\mathrm{MgO}$ & 0.98 & 0.78 & 1.09 & 1.02 & 0.03 & 0.01 & 0.01 & 0.06 \\
\hline $\mathrm{CuO}$ & 0.00 & 0.00 & 0.00 & 0.00 & 0.09 & 0.00 & 0.00 & 0.06 \\
\hline $\mathrm{MnO}$ & 3.05 & 2.20 & 3.16 & 3.36 & 6.57 & 6.19 & 6.26 & 6.97 \\
\hline $\mathrm{ZnO}$ & 0.12 & 0.00 & 0.13 & 0.16 & 0.37 & 0.39 & 0.67 & 0.47 \\
\hline $\mathrm{Al}_{2} \mathrm{O}_{3}$ & 1.19 & 0.10 & 1.29 & 1.78 & 0.45 & 0.16 & 1.25 & 0.44 \\
\hline $\mathrm{Fe}_{2} \mathrm{O}_{3} *$ & 43.18 & 44.44 & 43.57 & 42.61 & 43.70 & 44.52 & 46.00 & 44.21 \\
\hline $\mathrm{SiO}_{2}$ & 0.00 & 0.00 & 0.00 & 0.00 & 0.09 & 0.03 & 0.03 & 0.05 \\
\hline $\mathrm{TiO}_{2}$ & 0.09 & 0.00 & 0.10 & 0.03 & 0.15 & 0.17 & 0.05 & 0.19 \\
\hline $\mathrm{As}_{2} \mathrm{O}_{5}$ & 0.03 & 0.00 & 0.09 & 0.06 & 0.10 & 0.14 & 0.16 & 0.17 \\
\hline $\mathrm{P}_{2} \mathrm{O}_{5}$ & 32.81 & 32.57 & 32.76 & 32.80 & 30.67 & 31.19 & 31.97 & 30.25 \\
\hline $\mathrm{SO}_{3}$ & 0.00 & 0.00 & 0.00 & 0.00 & 0.06 & 0.18 & 0.05 & 0.10 \\
\hline $\mathrm{H}_{2} \mathrm{O}^{*}$ & 10.23 & 10.05 & 10.46 & 10.40 & 9.63 & 9.59 & 10.35 & 9.92 \\
\hline total & 99.06 & 98.60 & 99.81 & 99.46 & 94.06 & 95.13 & 98.76 & 94.44 \\
\hline $\mathrm{Na}^{+}$ & 0.832 & 0.654 & 0.859 & 0.981 & 0.230 & 0.191 & 0.044 & 0.229 \\
\hline $\mathrm{K}^{+}$ & 0.001 & 0.001 & 0.000 & 0.000 & 0.009 & 0.010 & 0.004 & 0.014 \\
\hline $\mathrm{Ca}^{2+}$ & 0.160 & 0.236 & 0.160 & 0.119 & 0.081 & 0.066 & 0.069 & 0.092 \\
\hline$\square$ & 0.007 & 0.109 & 0.000 & 0.000 & 0.680 & 0.733 & 0.883 & 0.665 \\
\hline$A$-site & 1.000 & 1.000 & 1.019 & 1.099 & 1.000 & 1.000 & 1.000 & 1.000 \\
\hline $\mathrm{Fe}^{2+}$ & 0.404 & 0.560 & 0.368 & 0.355 & 0.100 & 0.167 & 0.146 & 0.017 \\
\hline $\mathrm{Ba}^{2+}$ & 0.000 & 0.000 & 0.000 & 0.000 & 0.004 & 0.007 & 0.010 & 0.002 \\
\hline $\mathrm{Mg}^{2+}$ & 0.211 & 0.169 & 0.234 & 0.218 & 0.006 & 0.003 & 0.003 & 0.015 \\
\hline $\mathrm{Cu}^{2+}$ & 0.000 & 0.000 & 0.000 & 0.000 & 0.010 & 0.000 & 0.000 & 0.007 \\
\hline $\mathrm{Mn}^{2+}$ & 0.372 & 0.271 & 0.385 & 0.410 & 0.852 & 0.787 & 0.779 & 0.914 \\
\hline $\mathrm{Zn}^{2+}$ & 0.013 & 0.000 & 0.014 & 0.017 & 0.042 & 0.043 & 0.073 & 0.054 \\
\hline$B$-site & 1.000 & 1.000 & 1.000 & 1.000 & 1.014 & 1.007 & 1.010 & 1.009 \\
\hline $\mathrm{Al}^{3+}$ & 0.203 & 0.017 & 0.219 & 0.301 & 0.081 & 0.028 & 0.216 & 0.081 \\
\hline $\mathrm{Fe}^{3+}$ & 4.676 & 4.851 & 4.721 & 4.613 & 5.030 & 5.031 & 5.088 & 5.154 \\
\hline $\mathrm{Ti}^{4+}$ & 0.010 & 0.000 & 0.011 & 0.004 & 0.017 & 0.019 & 0.005 & 0.022 \\
\hline$C$-site & 4.889 & 4.868 & 4.950 & 4.918 & 5.128 & 5.077 & 5.310 & 5.257 \\
\hline $\mathrm{Si}^{4+}$ & 0.000 & 0.000 & 0.000 & 0.000 & 0.013 & 0.005 & 0.004 & 0.008 \\
\hline $\mathrm{As}^{5+}$ & 0.002 & 0.000 & 0.007 & 0.005 & 0.008 & 0.011 & 0.012 & 0.013 \\
\hline $\mathrm{P}^{5+}$ & 3.998 & 4.000 & 3.993 & 3.995 & 3.971 & 3.965 & 3.978 & 3.967 \\
\hline$S^{6+}$ & 0.000 & 0.000 & 0.000 & 0.000 & 0.007 & 0.020 & 0.005 & 0.012 \\
\hline T-site & 4.000 & 4.000 & 4.000 & 4.000 & 3.987 & 3.995 & 3.996 & 3.992 \\
\hline $\mathrm{H}^{+}$ & 9.822 & 9.725 & 10.045 & 9.981 & 9.826 & 9.605 & 10.148 & 10.252 \\
\hline $\mathrm{OH}^{*}$ & 5.828 & 5.731 & 6.039 & 5.975 & 5.822 & 5.612 & 6.141 & 6.243 \\
\hline $\mathrm{H}_{2} \mathrm{O} *$ & 1.997 & 1.997 & 2.003 & 2.003 & 2.002 & 1.996 & 2.004 & 2.004 \\
\hline
\end{tabular}

natrodufrénite, Krásno: 1 - mean of 5 spot analyses, 2-4 - representative spot analyses; Mn-rich dufrénite, Krásno: 5- mean of 9 spot analyses, 6-8 - representative spot analyses. FeO* a $\mathrm{Fe}_{2} \mathrm{O}_{3} *$ calculated from the proposed general formula; $\mathrm{H}_{2} \mathrm{O}^{*}$ and $(\mathrm{OH})^{*}$ calculated from the theoretical content of $\mathrm{H}_{2} \mathrm{O}=2.00$ and charge balance; empirical formulas were calculated on the basis of $(\mathrm{P}+\mathrm{As}+\mathrm{S}+\mathrm{Si})=4$. dominates over $\mathrm{Al}$ content with the maximum value of $0.30 a p f u$. Phosphorus is the major element in tetrahedral sites of both phases, As, $\mathrm{S}$ and Si contents reach 0.01-0.02 apfu. The empirical formula of natrodufrénite from Krásno calculated on the basis of $(\mathrm{P}+\mathrm{As}+\mathrm{S}+\mathrm{Si})=4$ is presented as $\left(\mathrm{Na}_{0.83} \mathrm{Ca}_{0.16} \square_{0.01}\right)_{\Sigma 1.00}$ $\left(\mathrm{Fe}_{0.40} \mathrm{Mn}_{0.37} \mathrm{Mg}_{0.21} \mathrm{Zn}_{0.01}\right)_{\Sigma 0.99}\left(\mathrm{Fe}_{4.68} \mathrm{Al}_{0.20} \mathrm{Ti}_{0.01}\right)_{\Sigma 4.89}$ $\left(\mathrm{PO}_{4}\right)_{400}(\mathrm{OH})_{5.82} .2 \mathrm{H}_{2} \mathrm{O}$. For Mn-rich dufrénite the empirical formula calculated on the same basis is $\left(\square_{0.68} \mathrm{Na}_{0.23} \mathrm{Ca}_{0.08}\right)_{\Sigma 1.00}\left(\mathrm{Mn}_{0.85} \mathrm{Fe}_{0.10} \mathrm{Zn}_{0.04}\right.$ $\left.\mathrm{Cu}_{0.01}\right)_{\Sigma 1.00}\left(\mathrm{Fe}_{5.03} \mathrm{Al}_{0.08} \mathrm{Ti}_{0.02}\right)_{\Sigma 5.13}\left[\left(\mathrm{PO}_{4}\right)_{3.97}\left(\mathrm{AsO}_{4}\right)_{0.01}\right.$ $\left.\left(\mathrm{SO}_{4}\right)_{0.01}\left(\mathrm{SiO}_{4}\right)_{0.01}\right]_{\Sigma 4.00}(\mathrm{OH})_{5.82} \cdot 2.00 \mathrm{H}_{2} \mathrm{O}$.

\section{Phosphosiderite $\mathrm{Fe}^{3+} \mathrm{PO}_{4} \cdot 2 \mathrm{H}_{2} \mathrm{O}$}

Phosphosiderite is a relatively common mineral in phosphate accumulations from the $5^{\text {th }}$ level of the Huber shaft. It forms irregular aggregates, up to $2 \mathrm{~mm}$ across, and veinlets to $5 \mathrm{~mm}$ thick (Fig. 80). Phosphosiderite has characteristic bluish grey colour and a weak lustre. It is intergrown with frondelite (Fig. 81), rockbridgeite, UNK9, beraunite, morinite, fluorapatite, and Mn-rich dufrenite. Beran (1999) reported from the same locality phosphosiderite as brown to black compact aggregates up to $10 \mathrm{~cm}$ long. The latter type of material was not available in the present study.

Phosphosiderite was identified by X-ray powder diffraction; refined unit-cell parameters (Table 27) are in good agreement with data published for this species. The chemical composition of phosphosiderite (Table 28) is close to the ideal formula - Fe (0.91-0.98 apfu), with limited substitution by Al (up to 0.04) and Mn (up to $0.02 a p f u$ ). Phosphorus dominates in the anion group, $\mathrm{S}$ and As are very low (0.004 apfu). The empirical formula of phosphosiderite can be presented on the basis of $(\mathrm{P}+\mathrm{As}+\mathrm{S})=1$ as $\left(\mathrm{Fe}_{0.95} \mathrm{Mn}_{0.01} \mathrm{Al}_{0.02}\right)_{\Sigma 0.98}\left(\mathrm{PO}_{4}\right)_{1.00}$ . $2 \mathrm{H}_{2} \mathrm{O}$.

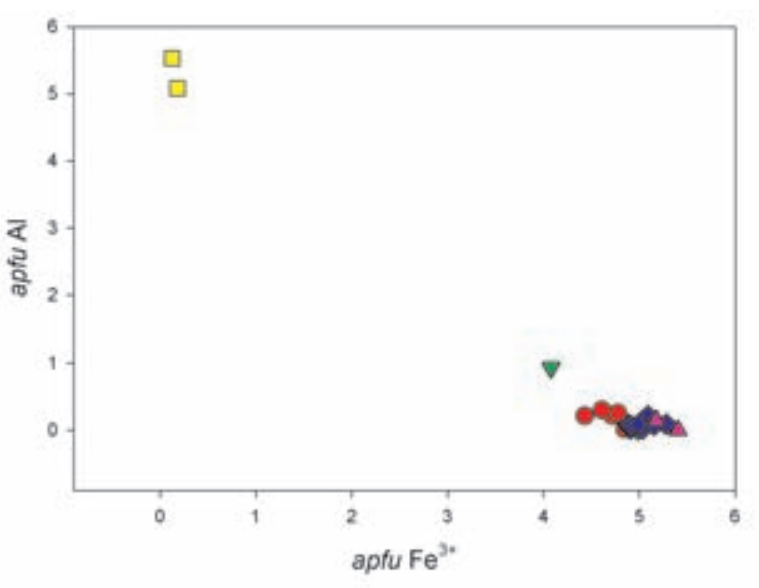

- natrodufrénite, Krásno (this paper)

natrodufrénite (Fontan et al. 1982, Roda-Robles et al. 1998)

burangaite (Knorring ef al, 1977; Selway of al. 1997)

Mn-rich dutrénite, Kralsno (this paper)

dufrénite (Anthony et al. 2000)

Fig. 79 A plot of apfu $\mathrm{Fe}^{3+} v s$. apfu $\mathrm{Al}$ in $C$-site for dufrénite-related minerals. 


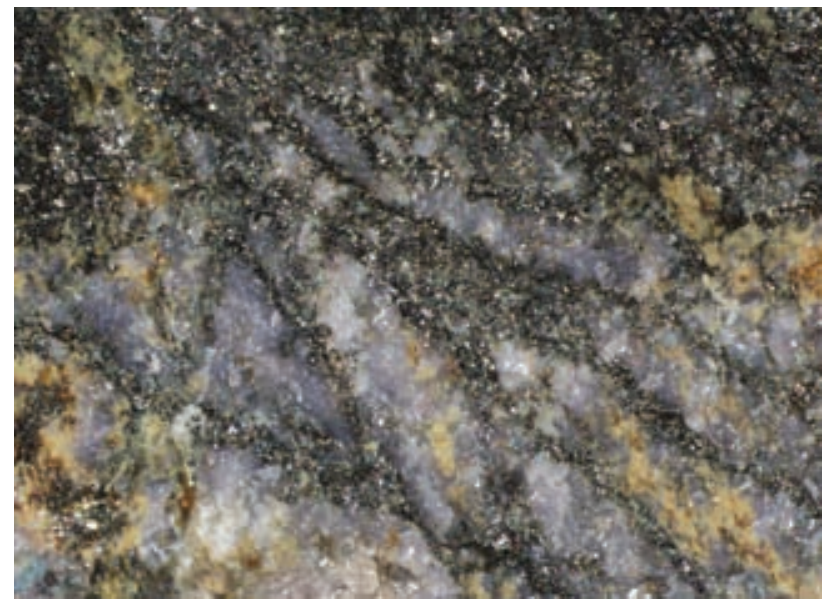

Fig. 80 Bluish grey phosphosiderite aggregates intergrown with dark aggregates of frondelite. $5^{\text {th }}$ level of the Huber shaft, Krásno. Width of photo $3.5 \mathrm{~mm}$. Nicon SMZ1500 microphotography by J. \& E. Sejkora.

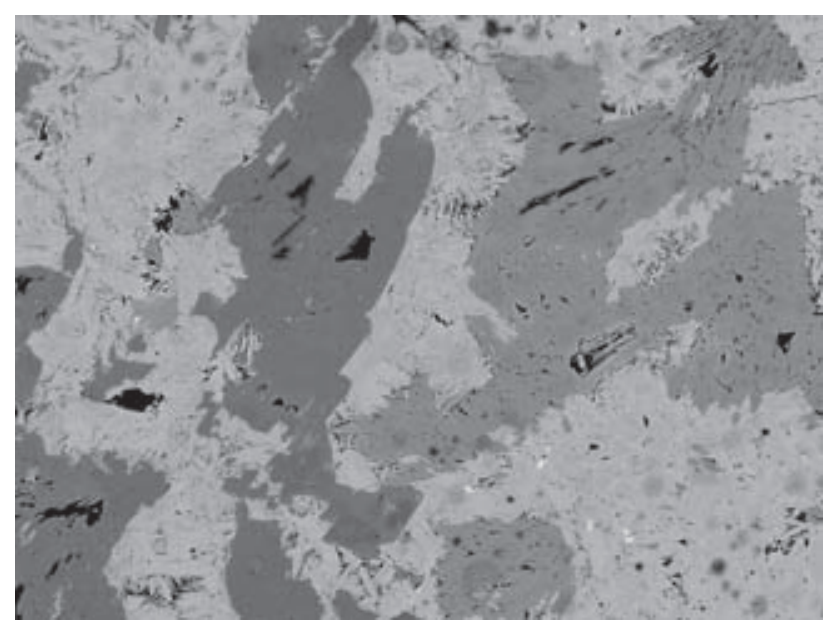

Fig. 81 Frondelite aggregates (light) replaced by beraunite (grey) and phosphosiderite (dark); $5^{\text {th }}$ level of the Huber shaft, Krásno. Width of photo $1 \mathrm{~mm}$. Cameca SX100, BSE photograph by J. Sejkora and R. Škoda.

Table 27 Unit-cell parameters of phosphosiderite (for monoclinic space group $\left.P 2_{1} / n\right)$

\begin{tabular}{|l|ccc|}
\hline & this paper & Fanfani - Zanazzi (1966) & Borensztajn (1966) \\
\hline $\mathrm{a}[\AA]$ & $5.317(8)$ & $5.330(3)$ & $5.32(5)$ \\
$\mathrm{b}[\AA]$ & $9.84(9)$ & $9.809(4)$ & $9.75(5)$ \\
$\mathrm{c}[\AA]$ & $8.673(4)$ & $8.714(5)$ & $8.65(5)$ \\
$\beta\left[{ }^{\circ}\right]$ & 90.1 & $90.6(1)$ & 90.6 \\
$\mathrm{~V}\left[\AA^{3}\right]$ & 453.8 & 455.6 & 448.7 \\
\hline
\end{tabular}

Table 28 Chemical composition of phosphosiderite (in wt. \%)

\begin{tabular}{|c|c|c|c|c|c|c|}
\hline & 1 & 2 & 3 & 4 & 5 & 6 \\
\hline $\mathrm{CaO}$ & 0.09 & 0.17 & 0.11 & 0.03 & 0.08 & 0.05 \\
\hline $\mathrm{BaO}$ & 0.04 & 0.00 & 0.18 & 0.01 & 0.07 & 0.00 \\
\hline $\mathrm{MgO}$ & 0.02 & 0.02 & 0.00 & 0.03 & 0.03 & 0.04 \\
\hline $\mathrm{PbO}$ & 0.06 & 0.19 & 0.00 & 0.00 & 0.00 & 0.00 \\
\hline $\mathrm{MnO}$ & 0.52 & 0.15 & 0.47 & 0.58 & 0.56 & 0.80 \\
\hline $\mathrm{ZnO}$ & 0.05 & 0.09 & 0.11 & 0.00 & 0.02 & 0.05 \\
\hline $\mathrm{Al}_{2} \mathrm{O}_{3}$ & 0.42 & 0.53 & 0.16 & 0.55 & 0.46 & 0.61 \\
\hline $\mathrm{Fe}_{2}^{2} \mathrm{O}_{3}$ & 39.97 & 39.99 & 40.34 & 41.07 & 40.70 & 40.60 \\
\hline $\mathrm{As}_{2} \mathrm{O}_{5}$ & 0.06 & 0.00 & 0.11 & 0.06 & 0.05 & 0.08 \\
\hline $\mathrm{P}_{2} \mathrm{O}_{5}$ & 37.51 & 38.50 & 37.55 & 38.12 & 37.84 & 37.55 \\
\hline $\mathrm{SO}_{3}$ & 0.04 & 0.06 & 0.06 & 0.02 & 0.00 & 0.00 \\
\hline $\mathrm{TiO}_{2}$ & 0.07 & 0.00 & 0.00 & 0.03 & 0.16 & 0.00 \\
\hline $\mathrm{H}_{2} \mathrm{O}^{*}$ & 19.08 & 19.57 & 19.12 & 19.38 & 19.23 & 19.09 \\
\hline total & 97.94 & 99.26 & 98.20 & 99.87 & 99.20 & 98.86 \\
\hline $\mathrm{Ca}^{2+}$ & 0.003 & 0.005 & 0.004 & 0.001 & 0.003 & 0.002 \\
\hline $\mathrm{Ba}^{2+}$ & 0.001 & 0.000 & 0.002 & 0.000 & 0.001 & 0.000 \\
\hline $\mathrm{Mg}^{2+}$ & 0.001 & 0.001 & 0.000 & 0.001 & 0.001 & 0.002 \\
\hline $\mathrm{Pb}^{2+}$ & 0.000 & 0.002 & 0.000 & 0.000 & 0.000 & 0.000 \\
\hline $\mathrm{Mn}^{2+}$ & 0.014 & 0.004 & 0.012 & 0.015 & 0.015 & 0.021 \\
\hline $\mathrm{Zn}^{2+}$ & 0.001 & 0.002 & 0.003 & 0.000 & 0.000 & 0.001 \\
\hline $\mathrm{Al}^{3+}$ & 0.016 & 0.019 & 0.006 & 0.020 & 0.017 & 0.023 \\
\hline $\mathrm{Fe}^{3+}$ & 0.945 & 0.922 & 0.952 & 0.957 & 0.955 & 0.960 \\
\hline $\mathrm{Ti}^{4+}$ & 0.002 & 0.000 & 0.000 & 0.001 & 0.004 & 0.000 \\
\hline subtotal & 0.983 & 0.955 & 0.979 & 0.995 & 0.996 & 1.008 \\
\hline $\mathrm{As}^{5+}$ & 0.001 & 0.000 & 0.002 & 0.001 & 0.001 & 0.001 \\
\hline $\mathrm{P}^{5+}$ & 0.998 & 0.999 & 0.997 & 0.999 & 0.999 & 0.999 \\
\hline$S^{6+}$ & 0.001 & 0.001 & 0.001 & 0.000 & 0.000 & 0.000 \\
\hline subtotal & 1.000 & 1.000 & 1.000 & 1.000 & 1.000 & 1.000 \\
\hline $\mathrm{H}_{2} \mathrm{O}$ & 4.000 & 4.000 & 3.999 & 4.001 & 4.001 & 4.000 \\
\hline
\end{tabular}

1 - mean of 18 spot analyses; $2-6$ - representative spot analyses. $\mathrm{H}_{2} \mathrm{O} *$ calculated on the basis of theoretical content $\mathrm{H}_{2} \mathrm{O}=2.00$, empirical formulas were calculated on the basis of $(\mathrm{P}+\mathrm{As}+\mathrm{S})=1$.

\section{Rockbridgeite}

see minerals of the frondelite - rockbridgeite series

\section{Strengite $\mathrm{Fe}^{3+} \mathrm{PO}_{4} \cdot 2 \mathrm{H}_{2} \mathrm{O}$}

Very rare strengite occurs in cavities of phosphate accumulations at the $5^{\text {th }}$ level of the Huber shaft on minute crystals of rockbridgeite - frondelite or fluorapatite as perfect elongated crystals up to $4 \mathrm{~mm}$ long (Fig. 82), with a striking purple red colour and an intense vitreous lustre. Strengite of the same colour in $1 \mathrm{~mm}$ long grains intergrown with morinite aggregates and fluorapatite was very rare. It has been identified by X-ray powder diffraction; its refined unit-cell parameters correspond closely the published data (Table 29). A semiquantitative study of chemical composition of strengite confirmed major contents of $\mathrm{Fe}$ and $\mathrm{P}$, contents of other elements (Al, Mn, As, etc.) were below detection limit of the used method (c. $0.2-0.5$ wt. $\%$ ). 


\section{Minerals of the triplite - zwieselite series $\mathrm{Mn}_{2}{ }_{2}\left(\mathrm{PO}_{4}\right)(\mathrm{F}, \mathrm{OH})-\mathrm{Fe}^{2+}{ }_{2}\left(\mathrm{PO}_{4}\right)(\mathrm{F}, \mathrm{OH})$}

Minerals of the triplite group were reported from the Krásno ore district in numerous publications from $19^{\text {th }}$ century (see Beran 1999). Later on, Fisher (1957) studied the mineral in samples collected at the dumps near the Schnöd stock. The paper contains X-ray powder diffraction data and results of approximate, semiquantitative analysis. Fisher (1957) recognized two forms of triplite - dark and light triplite. Based on analogy with Hagendorf pegmatite (older dark triplite in feldspar, younger light triplite in quartz) he considered the possibility that the two forms of triplite may represent two independent generations. Beran (1999) described from samples of phosphate accumulations collected at the $5^{\text {th }}$ level of the Huber shaft occurrence of zwieselite and triploidite in addition to predominating triplite. However, these descriptions are not confirmed by the present study.

We have studied a large number of samples of minerals from the triplite group, collected in the Huber open pit, in phosphate accumulation at the $5^{\text {th }}$ level of the Huber shaft and for comparison several historical specimens collected before 1830, probably in the Gellnauer vein system. Triplite from the Huber stock forms irregular aggregates, up to $10 \mathrm{~cm}$ across, which are usually partly replaced by younger fluorapatite and isokite (open pit and

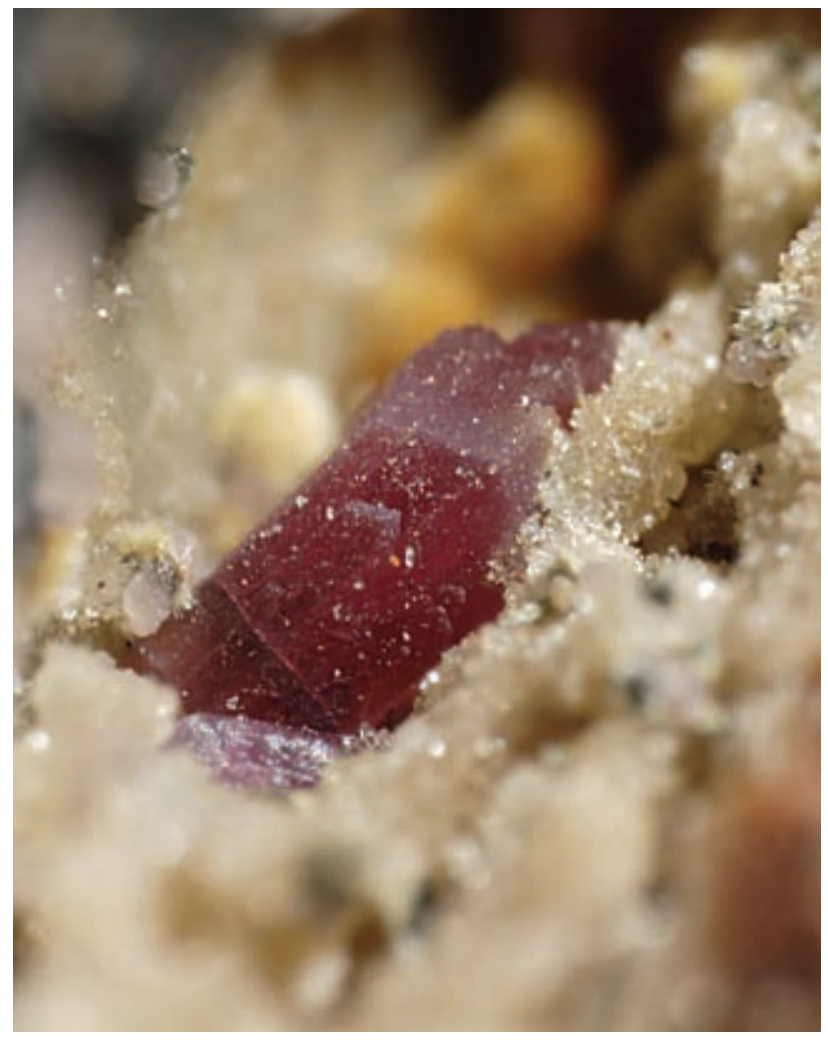

Fig. 82 Purple-red strengite crystal on aggregates of light-coloured fluorapatite. $5^{\text {th }}$ level of the Huber shaft, Krásno. Width of photo $3.1 \mathrm{~mm}$. Nicon SMZ1500 microphotography by J. \& E. Sejkora.

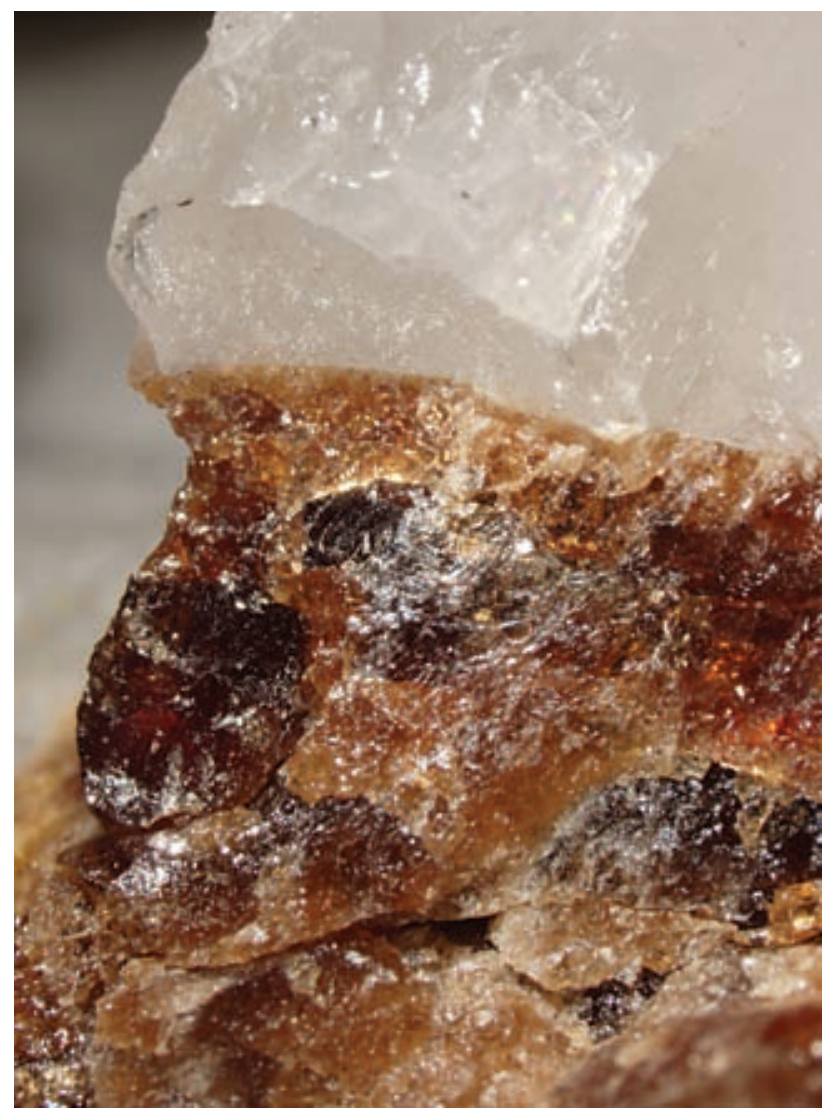

Fig. 83 Triplite aggregates with white quartz, $5^{\text {th }}$ level of the Huber shaft, Krásno. Width of photo $9 \mathrm{~mm}$. Microphotography Nicon SMZ1500 by J. \& E. Sejkora.

Table 29 Unit-cell parameters of strengite (for orthorhombic space group $\mathrm{Pbca}$ )

\begin{tabular}{|l|cc|}
\hline & this paper & Taxer - Bartl (2004) \\
\hline $\mathrm{a}[\AA]$ & $8.750(6)$ & $8.722(3)$ \\
$\mathrm{b}[\AA]$ & $9.821(7)$ & $9.878(2)$ \\
$\mathrm{c}[\AA]$ & $10.126(7)$ & $10.119(1)$ \\
$\mathrm{V}\left[\AA^{3}\right]$ & $870.2(6)$ & 871.79 \\
\hline
\end{tabular}

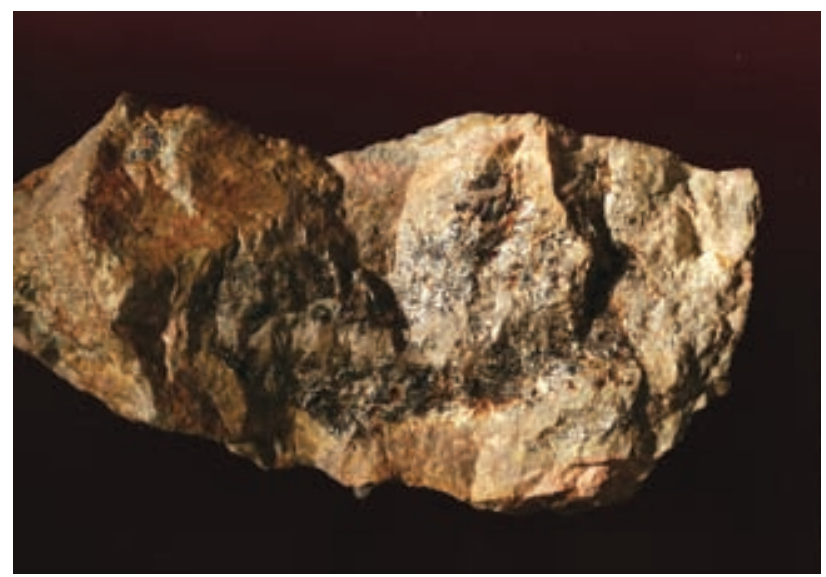

Fig. 84 Aggregates of Mn-rich zwieselite; Gellnauer vein system, Krásno. Width of photo $9 \mathrm{~cm}$. Macrophotography Canon DS1 by J. \& E. Sejkora. 
$5^{\text {th }}$ level) or fluorapatite and minerals of the series rockbridgeite - frondelite (only $5^{\text {th }}$ level of the Huber shaft). Triplite aggregates are light or dark brown (Fig. 83), they have a characteristic vitreous to greasy lustre and are partly transparent with red colour in small splinters. The differences in colour of triplite do not indicate existence of two generations, but rather the extent of alteration or weathering of individual samples. Dark triplite is coloured by oxides and hydroxides of Fe and Mn. All triplite occurrences are associated with compact or coarsegrained quartz in greisens. Samples from the Gellnauer vein system contain Mn-rich zwieselite in dark brown aggregates larger than $10 \mathrm{~cm}$ (Fig. 84). The aggregates are strongly replaced by compact fluorapatite from margin (Fig. 85) and this fluorapatite is succesively strongly replaced by fine-grained isokite. Triplite (or zwieselite) in all samples studied is compositionaly quite homogeneous, except rare and weak zoning in Fe/Mn ratio. Dur-

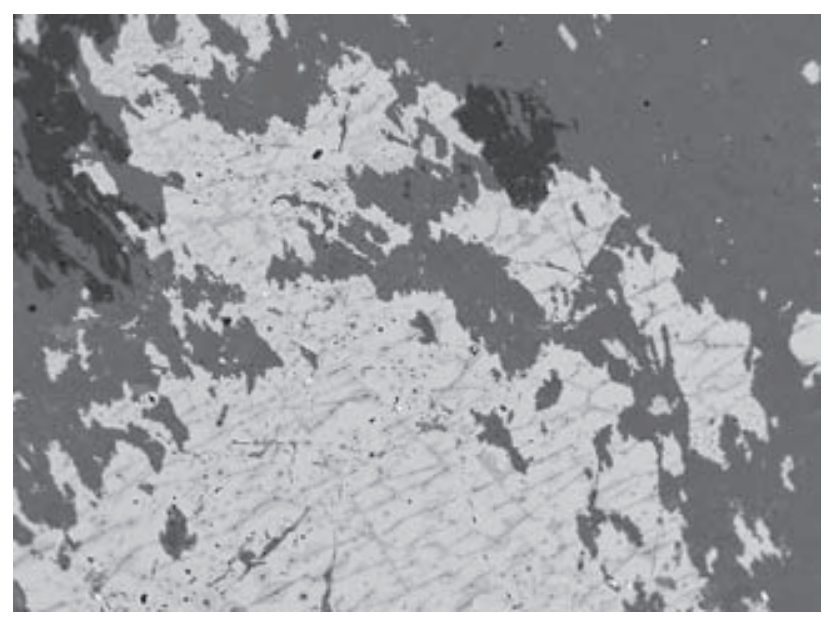

Fig. 85 Zwieselite aggregates (light) intensively replaced by fluorapatite (grey), fluorapatite is in turn replaced by isokite aggregates (dark). Gellnauer vein system, Krásno. Width of photo $1.2 \mathrm{~mm}$. Cameca SX100, BSE photograph by J. Sejkora and R. Škoda. ing late alteration, resulting in corrosion cavities in phosphate accumulations, triplite appeared to be one of the most stable minerals. Various samples show fresh triplite aggregates and minute, lustrous triplite grains protruding into the cavities.

X-ray powder diffraction data for triplite from Krásno correspond to the published data for minerals of the triplite - zwieselite series. Owing to chemical composition falling in between triplite and zwieselite (see below), it is not possible to recognize these minerals by X-ray patterns. Refined unit-cell parameters (Table 30) correspond to minerals of this group. With regard to extensive substitutions in $M$ - and $Z$-sites and polytypism (Chopin et al. 2004), it is not possible to separate intermediate members of this group on the basis of unit-cell parameters.

The chemical composition of minerals of the triplite group can be expressed by the general formula $\mathrm{M}_{2}\left(\mathrm{TO}_{4}\right)(\mathrm{Z}) . \mathrm{Mn}^{2+}, \mathrm{Fe}^{2+}, \mathrm{Mg}$ and $\mathrm{Ca}$ enter the octahdral $M$-sites, tetrahedra $\mathrm{TO}_{4}$ are occupied by $\mathrm{P}, \mathrm{As}, \mathrm{V}$ and $\mathrm{Si}$ and $Z$-site is dominated by $\mathrm{F}$ or $\mathrm{OH}$ (Waldrop 1969). Triplite $\left(\mathrm{Mn}_{2} \mathrm{PO}_{4} \mathrm{~F}\right)$ is isostructural with zwieselite $\left(\mathrm{Fe}_{2} \mathrm{PO}_{4} \mathrm{~F}\right)$ and wagnerite $\left(\mathrm{Mg}_{2} \mathrm{PO}_{4} \mathrm{~F}\right)$ and it is structurally related to triploidite $\left(\mathrm{Mn}_{2} \mathrm{PO}_{4} \mathrm{OH}\right)$ and wolfeite $\left(\mathrm{Fe}_{2} \mathrm{PO}_{4} \mathrm{OH}\right)$. The triplite group shows a wide (probably unlimited) isomorphism among all above given end-members.

The chemical composition of the studied minerals of the triplite group (Table 31) is relatively uniform within individual localities, but there is considerable variation in $\mathrm{Mn}, \mathrm{Fe}$ a Mg contents among the localities (Fig. 86). Samples from the Gellnauer vein system correspond to $\mathrm{Mn}$-rich and $\mathrm{Mg}$-poor zwieselite. Samples from the $\mathrm{Hu}-$ ber stock contain uniform $\mathrm{Mn}$ and $\mathrm{Fe}$ abundances and correspond to Fe-rich triplite (Fig. 87), but they show variation in $\mathrm{Mg}$ content. Triplite samples from the $5^{\text {th }}$ level of the Huber shaft are Mg-poor (max. 0.01 apfu), but triplites from the Huber stock contain 0.28 to 0.31 apfu $\mathrm{Mg}$. All the studied samples contain nearly constant quantity of $\mathrm{Ca}$ in $M$-site, 0.04 to $0.08 \mathrm{apfu}$. The tetrahedral $T$-site is occupied almost exclusively by $\mathrm{P}$, contents of As, S and Si are low and irregular, always less than 0.004

Table 30 Unit-cell parameters for minerals of triplite group (for monoclinic space group $C 2 / c$ )

\begin{tabular}{|l|ccccc|}
\hline & $\begin{array}{l}\text { triplite*1 } \\
\text { this paper }\end{array}$ & $\begin{array}{l}\text { triplite*2 } \\
\text { this paper }\end{array}$ & $\begin{array}{l}\text { zwieselite*3 } \\
\text { this paper }\end{array}$ & $\begin{array}{c}\text { triplite*4 } \\
\text { Waldrop (1968) }\end{array}$ & $\begin{array}{c}\text { zwieselite*5 } \\
\text { Yakubovich } \text { et al. }(1978)\end{array}$ \\
\hline $\mathrm{a}[\AA]$ & $13.276(4)$ & $13.219(8)$ & $13.233(8)$ & $13.185(1)$ & $13.641(3)$ \\
$\mathrm{b}[\AA]$ & $6.487(1)$ & $6.461(2)$ & $6.492(2)$ & $6.454(1)$ & $6.489(1)$ \\
$\mathrm{c}[\AA]$ & $10.020(3)$ & $9.987(2)$ & $9.995(6)$ & $9.937(1)$ & $9.890(3)$ \\
$\beta\left[{ }^{\circ}\right]$ & $119.51(1)$ & $119.33(2)$ & $119.38(3)$ & $119.00(6)$ & $118.40(2)$ \\
$\mathrm{V}\left[\AA^{3}\right]$ & $750.9(5)$ & $743.6(9)$ & $748.2(9)$ & 739.6 & 733.5 \\
\hline
\end{tabular}

*1 Fe-rich triplite, $5^{\text {th }}$ level of the Huber shaft, Krásno $-\left(\mathrm{Mn}_{1.05} \mathrm{Fe}_{0.85} \mathrm{Ca}_{0.07} \mathrm{Mg}_{0.01}\right)_{\Sigma 1.98}\left(\mathrm{PO}_{4}\right)\left(\mathrm{F}_{0.67}(\mathrm{OH})_{0.31}\right)_{\Sigma 0.98}$

*2 Fe- and Mg-rich triplite, Huber open pit, Krásno - $\left(\mathrm{Mn}_{0.88} \mathrm{Fe}_{0.70} \mathrm{Mg}_{0.29} \mathrm{Ca}_{0.06}\right)_{\Sigma 1.93}\left(\mathrm{PO}_{4}\right)\left(\mathrm{F}_{0.67}(\mathrm{OH})_{0.32}\right)_{\Sigma 0.99}$

*3 Mn-rich zwieselite, Gellnauer vein system, Krásno - $\left(\mathrm{Fe}_{1.06} \mathrm{Mn}_{0.84} \mathrm{Ca}_{0.06}\right)_{\Sigma 1.96}\left(\mathrm{PO}_{4}\right)\left(\mathrm{F}_{0.66}(\mathrm{OH})_{0.32}\right)_{\Sigma 0.98}$

*4 Mg-rich triplite $\left(\mathrm{Mn}_{0.88} \mathrm{Mg}_{0.70} \mathrm{Fe}_{0.32} \mathrm{Ca}_{0.10}\right)_{\Sigma 2.00}\left(\mathrm{PO}_{4}\right) \mathrm{F}$

*5 zwieselite, synthetic Fe end-member

*6 wagnerite (= formerly magniotriplite) $\left(\mathrm{Mg}_{0.89} \mathrm{Fe}_{0.88} \mathrm{Mn}_{0.23}\right)_{\Sigma 2.00}\left(\mathrm{PO}_{4}\right) \mathrm{F}$ 
Table 31 Chemical composition of triplite group minerals from Krásno (in wt. \%)

\begin{tabular}{|c|c|c|c|c|c|c|c|c|c|}
\hline & 1 & 2 & 3 & 4 & 5 & 6 & 7 & 8 & 9 \\
\hline $\mathrm{Na}_{2} \mathrm{O}$ & 0.06 & 0.00 & 0.01 & 0.00 & 0.01 & 0.05 & 0.01 & 0.00 & 0.00 \\
\hline $\mathrm{K}_{2} \mathrm{O}$ & 0.04 & 0.00 & 0.00 & 0.00 & 0.26 & 0.19 & 0.01 & 0.00 & 0.02 \\
\hline $\mathrm{CaO}$ & 1.80 & 1.87 & 1.75 & 1.89 & 1.02 & 1.70 & 1.68 & 1.46 & 1.65 \\
\hline $\mathrm{SrO}$ & 0.00 & 0.00 & 0.02 & 0.04 & 0.00 & 0.02 & 0.00 & 0.03 & 0.01 \\
\hline $\mathrm{BaO}$ & 0.00 & 0.00 & 0.06 & 0.08 & 0.00 & 0.29 & 0.00 & 0.15 & 0.00 \\
\hline $\mathrm{MgO}$ & 0.09 & 0.06 & 0.03 & 0.19 & 5.56 & 5.46 & 0.00 & 0.03 & 0.02 \\
\hline $\mathrm{MnO}$ & 32.51 & 33.69 & 33.34 & 32.27 & 29.34 & 29.14 & 27.44 & 27.54 & 25.21 \\
\hline $\mathrm{FeO}$ & 27.96 & 27.53 & 27.40 & 27.96 & 24.85 & 24.04 & 33.21 & 33.43 & 35.69 \\
\hline $\mathrm{CuO}$ & 0.00 & 0.00 & 0.02 & 0.00 & 0.00 & 0.00 & 0.00 & 0.07 & 0.00 \\
\hline $\mathrm{ZnO}$ & 0.23 & 0.10 & 0.00 & 0.42 & 0.29 & 0.18 & 0.24 & 0.14 & 0.15 \\
\hline $\mathrm{PbO}$ & 0.07 & 0.02 & 0.17 & 0.08 & 0.01 & 0.14 & 0.00 & 0.00 & 0.23 \\
\hline $\mathrm{Al}_{2} \mathrm{O}_{3}$ & 0.00 & 0.02 & 0.00 & 0.04 & 0.00 & 0.01 & 0.00 & 0.02 & 0.02 \\
\hline $\mathrm{TiO}_{2}$ & 0.09 & 0.05 & 0.06 & 0.07 & 0.11 & 0.18 & 0.03 & 0.06 & 0.41 \\
\hline $\mathrm{SiO}_{2}$ & 0.07 & 0.03 & 0.00 & 0.03 & 0.04 & 0.00 & 0.02 & 0.00 & 0.05 \\
\hline $\mathrm{P}_{2} \mathrm{O}_{5}$ & 32.09 & 31.27 & 31.84 & 31.40 & 32.91 & 33.83 & 31.88 & 31.74 & 31.02 \\
\hline $\mathrm{As}_{2} \mathrm{O}_{5}$ & 0.00 & 0.04 & 0.00 & 0.11 & 0.09 & 0.00 & 0.00 & 0.09 & 0.00 \\
\hline $\mathrm{SO}_{3}$ & 0.03 & 0.01 & 0.09 & 0.00 & 0.02 & 0.02 & 0.00 & 0.03 & 0.00 \\
\hline $\mathrm{Cl}$ & 0.00 & 0.00 & 0.01 & 0.00 & 0.02 & 0.00 & 0.01 & 0.00 & 0.01 \\
\hline $\mathrm{F}$ & 6.37 & 6.28 & 6.44 & 5.40 & 6.76 & 6.77 & 5.80 & 5.75 & 5.31 \\
\hline $\mathrm{O}=\mathrm{F}$ & -2.68 & -2.64 & -2.71 & -2.27 & -2.85 & -2.85 & -2.44 & -2.42 & -2.23 \\
\hline $\mathrm{O}=\mathrm{Cl}$ & 0.00 & 0.00 & 0.00 & 0.00 & 0.00 & 0.00 & 0.00 & 0.00 & 0.00 \\
\hline $\mathrm{H}_{2} \mathrm{O}^{*}$ & 1.48 & 2.39 & 1.58 & 2.98 & 1.76 & 1.13 & 2.04 & 2.27 & 3.47 \\
\hline total & 100.191 & 100.71 & 100.111 & 100.701 & 100.181 & 100.27 & 99.921 & 100.381 & 101.04 \\
\hline $\mathrm{Na}^{+}$ & 0.004 & 0.000 & 0.001 & 0.000 & 0.001 & 0.003 & 0.001 & 0.000 & 0.000 \\
\hline $\mathrm{K}^{+}$ & 0.002 & 0.000 & 0.000 & 0.000 & 0.012 & 0.008 & 0.000 & 0.000 & 0.001 \\
\hline $\mathrm{Ca}^{2+}$ & 0.071 & 0.076 & 0.069 & 0.076 & 0.039 & 0.064 & 0.067 & 0.058 & 0.067 \\
\hline $\mathrm{Sr}^{2+}$ & 0.000 & 0.000 & 0.001 & 0.001 & 0.000 & 0.000 & 0.000 & 0.001 & 0.000 \\
\hline $\mathrm{Ba}^{2+}$ & 0.000 & 0.000 & 0.001 & 0.001 & 0.000 & 0.004 & 0.000 & 0.002 & 0.000 \\
\hline $\mathrm{Mg}^{2+}$ & 0.005 & 0.004 & 0.001 & 0.010 & 0.296 & 0.284 & 0.000 & 0.002 & 0.001 \\
\hline $\mathrm{Mn}^{2+\cdot \cdot}$ & 1.011 & 1.075 & 1.045 & 1.025 & 0.889 & 0.861 & 0.861 & 0.866 & 0.812 \\
\hline $\mathrm{Fe}^{2+}$ & 0.858 & 0.868 & 0.848 & 0.877 & 0.743 & 0.702 & 1.028 & 1.038 & 1.135 \\
\hline $\mathrm{Cu}^{2+}$ & 0.000 & 0.000 & 0.001 & 0.000 & 0.000 & 0.000 & 0.000 & 0.002 & 0.000 \\
\hline $\mathrm{Zn}^{2+}$ & 0.006 & 0.003 & 0.000 & 0.012 & 0.008 & 0.005 & 0.007 & 0.004 & 0.004 \\
\hline $\mathrm{Pb}^{2+}$ & 0.001 & 0.000 & 0.002 & 0.001 & 0.000 & 0.001 & 0.000 & 0.000 & 0.002 \\
\hline $\mathrm{Al}^{3+}$ & 0.000 & 0.001 & 0.000 & 0.002 & 0.000 & 0.000 & 0.000 & 0.001 & 0.001 \\
\hline $\mathrm{Ti}^{4+}$ & 0.003 & 0.001 & 0.002 & 0.002 & 0.003 & 0.005 & 0.001 & 0.002 & 0.012 \\
\hline$M$-site & 1.960 & 2.027 & 1.970 & 2.006 & 1.991 & 1.937 & 1.964 & 1.974 & 2.034 \\
\hline $\mathrm{Si}^{4+}$ & 0.002 & 0.001 & 0.000 & 0.001 & 0.001 & 0.000 & 0.001 & 0.000 & 0.002 \\
\hline $\mathrm{P}^{5+}$ & 0.997 & 0.998 & 0.998 & 0.997 & 0.997 & 1.000 & 0.999 & 0.997 & 0.998 \\
\hline $\mathrm{As}^{5+}$ & 0.000 & 0.001 & 0.000 & 0.002 & 0.002 & 0.000 & 0.000 & 0.002 & 0.000 \\
\hline$S^{6+}$ & 0.001 & 0.000 & 0.002 & 0.000 & 0.000 & 0.000 & 0.000 & 0.001 & 0.000 \\
\hline$T$-site & 1.000 & 1.000 & 1.000 & 1.000 & 1.000 & 1.000 & 1.000 & 1.000 & 1.000 \\
\hline $\mathrm{F}^{-}$ & 0.739 & 0.748 & 0.753 & 0.640 & 0.764 & 0.748 & 0.679 & 0.675 & 0.638 \\
\hline $\mathrm{Cl}^{-}$ & 0.000 & 0.000 & 0.001 & 0.000 & 0.001 & 0.000 & 0.001 & 0.000 & 0.001 \\
\hline$* \mathrm{OH}^{-}$ & 0.178 & 0.309 & 0.192 & 0.376 & 0.209 & 0.125 & 0.247 & 0.278 & 0.452 \\
\hline$Z$-site & 0.917 & 1.057 & 0.946 & 1.016 & 0.975 & 0.873 & 0.928 & 0.953 & 1.091 \\
\hline
\end{tabular}

Representative spot analyses: $1-4-$ triplite, $5^{\text {th }}$ level of the Huber shaft; 5-6 - Huber open pit; 7-9 - zwieselite, Gellnauer vein system.

$\mathrm{H}_{2} \mathrm{O}^{*}$ and $(\mathrm{OH})^{*}$ calculated on the basis of charge balance, empirical formulas were calculated on the basis of $(\mathrm{P}+\mathrm{As}+\mathrm{S}+\mathrm{Si})=1$.

apfu. There is a limited variation in Z-site occupancy among individual localities (Fig. 88). Fluorine is always the dominant anion (0.53 to 0.77 apfu), irregular $\mathrm{Cl}$ contents do not exceed 0.002 apfu. The empirical formulas calculated on the basis of $(\mathrm{P}+\mathrm{As}+\mathrm{S}+\mathrm{Si})=1$ for representative spot analyses of triplite group minerals from Krásno are given in Table 31.

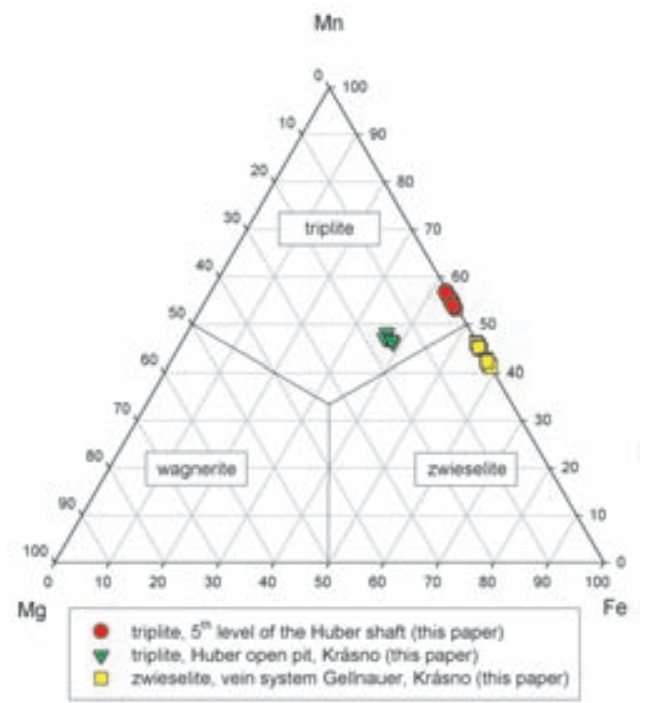

Fig. 86 Ternary plot of $M$-site occupancy (atomic ratio) in triplite group minerals from Krásno.

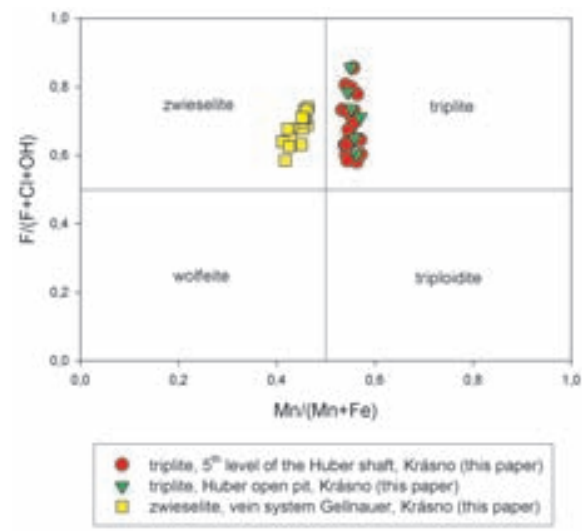

Fig. 87 Diagram $\mathrm{Mn} /(\mathrm{Mn}+\mathrm{Fe}) v s . \mathrm{F} /(\mathrm{F}+\mathrm{Cl}+\mathrm{OH})(p f u)$ for minerals of the triplite group from Krásno.

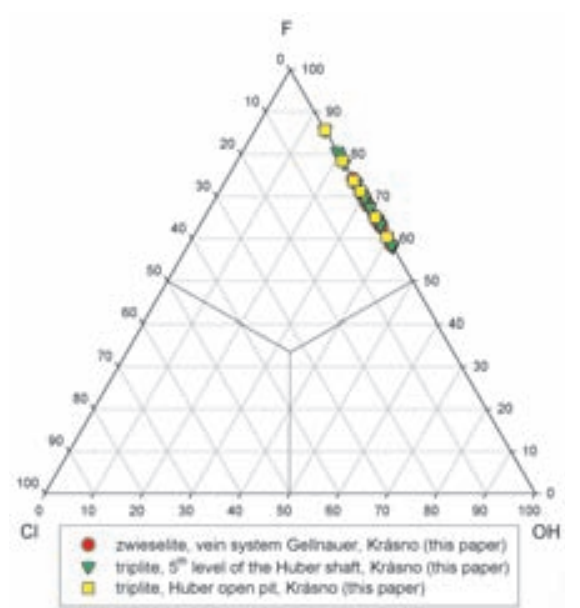

Fig. 88 Ternary plot of $Z$-site occupancy in triplite group minerals from Krásno. 


\section{Turqouise}

see chalcosiderite

$$
\text { Vivianite } \mathrm{Fe}_{3}^{2+}\left(\mathrm{PO}_{4}\right)_{2} \cdot 8 \mathrm{H}_{2} \mathrm{O}
$$

This mineral has been found in the Huber open pit as blue grey spheroidal aggregates of lens-shaped crystals deposited on crystals of hydrothermal quartz. The size of the aggregates is up to $5 \mathrm{~mm}$. In this case, no other secondary minerals accompany vivianite. The mineral was identified by X-ray powder diffraction.

\section{Wavellite $\mathrm{Al}_{3}\left(\mathrm{PO}_{4}\right)_{2}(\mathrm{OH}, \mathrm{F})_{3} .5 \mathrm{H}_{2} \mathrm{O}$}

Presence of wavellite in the Krásno ore district is known for a long time (see Beran 1999). Korbel (1991) gave a spectral analysis and X-ray powder diffraction data. He identified two forms of wavellite in material from the Huber stock. The first type forms white radiating aggregates with fibers, up to $5 \mathrm{~mm}$ long. The second type occurs as grey white radiating spheroidal aggregates, up to $3 \mathrm{~mm}$ in diameter.

The present study confirmed the existence of both morphological types of wavellite described by Korbel (1991) in samples from the Huber open pit. Radiating aggregates of wavellite, rarely up to $1 \mathrm{~cm}$ long, occur in cavities together with beraunite, fluellite and siderite. In addition, radiating aggregates of wavellite longer than $1 \mathrm{~cm}$ (Fig. 89) with a weak colour zoning across the fibres have been found. The occurrence of wavellite was confirmed by X-ray powder diffraction.

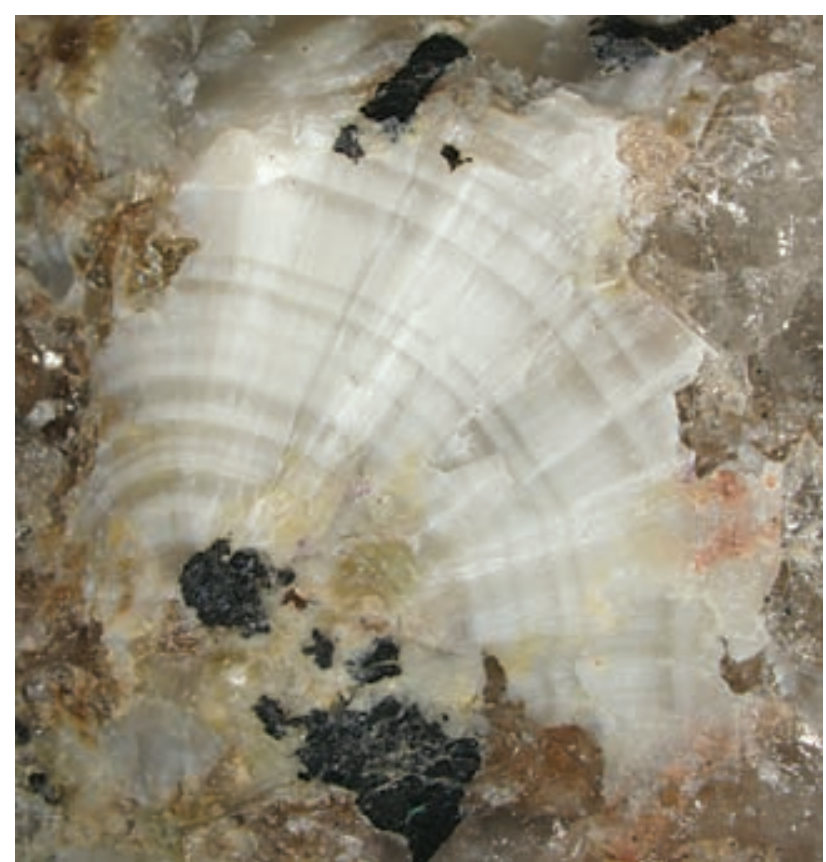

Fig. 89 Radiating aggregate of wavellite. Huber open pit, Krásno. Width of photo $16 \mathrm{~mm}$. Nicon SMZ1500 microphotography by J. \& E. Sejkora.

\section{Waylandite}

see minerals of the crandallite group

\section{Whitmoreite}

see earlshannonite and whitmoreite (arthurite group)

\section{Zwieselite}

see minerals of the triplite - zwieselite series

\section{Formation of mineral associations in phosphate accumulations in the Huber stock}

Mineral associations and chemical composition of minerals at two localities in Krásno, i.e., Huber open pit and the $5^{\text {th }}$ level of the Huber shaft, show numerous similarities, but there are also some differences. Consenquently, their evolution is discussed separately. In addition to the minerals described in this paper the discussion concerns also probable new mineral species (Sejkora et al. 2006) occurring in these associations.

\section{Huber open pit}

Phosphates exposed in the Huber open pit evolved in the apical part of the stock, which was probably completely greisenized and contains local bodies of coarse-grained or compact quartz. The studied samples come from level c. 20 to $40 \mathrm{~m}$ below the contact of the upper part of the stock with host rocks. This corresponds approximately to the position about $50-80 \mathrm{~m}$ below the original land surface. Accurate vertical positions are difficult to determine, as the structure was affected by extensive collapse caused by historical mining. The primary phosphates occur in masses of white compact quartz in greisens, whereas younger re-mobilized phosphates originated in cavities of coarse-grained quartz gangue.

Abundant triplite and compact fluorapatite I (Fig. 90) were identified as the primary phosphates. Replacement of triplite by younger fluorapatite II, starting from margins of aggregates and along fractures, was initiated probably in early hydrothermal stage. During the following stage, this newly formed fluorapatite II and partly primary fluorapatite I were extensively replaced by aggregates of isokite. Isokite formation is preferentially restricted on in fluorapatite domains. At the rarely observed isokite/ triplite boundary triplite shows no replacement features.

The formation of abundant isokite aggregates requires import of $\mathrm{Mg}$, because solubility of $\mathrm{Mg}$ in highly evolved peraluminous systems is low (Puziewicz - Johannes 1988, 1990). Magnesium was likely imported by aqueous fluids from rocks of the metamorphic envelope or perhaps from altered micas in underlying granite. Opening of the system as early as the beginning stage of phosphate accumulation is indicated by the increased contents 


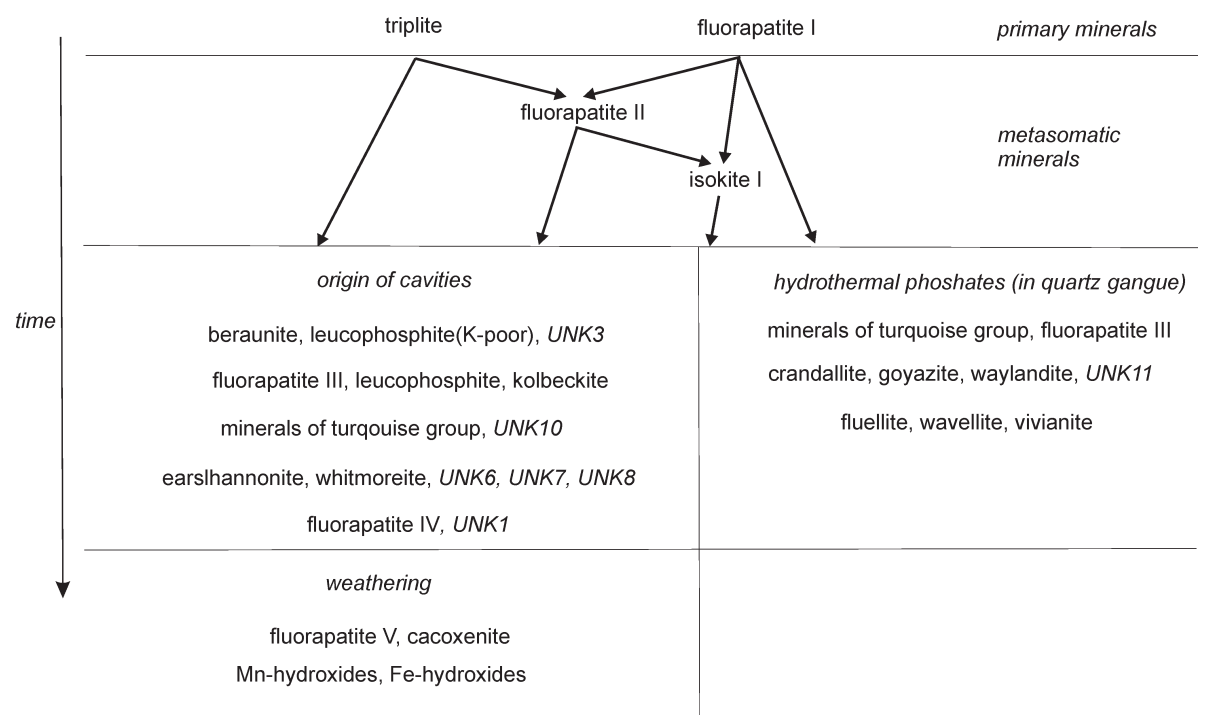

Fig. 90 Schematic presentation of the evolution of phosphate mineral associations in the Huber open pit, Krásno. of $\mathrm{Mg}$ in primary triplite from the Huber open pit $(\mathrm{Mg} /(\mathrm{Mg}+\mathrm{Fe}+\mathrm{Mn})$ about 0.16$)$, whereas triplite formed at a minimal depth of $200 \mathrm{~m}$ of the contact $\left(5^{\text {th }}\right.$ level of the Huber shaft) has $\mathrm{Mg} /(\mathrm{Mg}+\mathrm{Fe}+\mathrm{Mn})$ only about 0.004 . The high fluorine contents in fluorapatite, triplite and isokite suggest F-rich environment. The following stage of the evolution of phosphate accumulations is characterized by selective dissolution of fine-grained or compact fluorapatite associated with formation of incoherent isokite aggregates and abundant corrosion cavities from several $\mathrm{mm}$ up to $10 \mathrm{~cm}$ in size. In the process of fluorapatite dissolution, isokite remains stable, or may be partly dissolved and removed; however, triplite was not affected by these processes.

During the next stage crystallization of beraunite, K-poor leucophosphite and UNK3, fluorapatite, leucophosphite and kolbeckite in corrosion cavities took place. Later on, minerals of the turqouise group (chalcosiderite, turquoise, UNK10) and arthurite group (earlshannonite, whitmoreite, UNK6, UNK7, UNK8) crystallized. Remarkable compositional zoning on microscale is characteristic for this stage. The youngest minerals in cavities include fluorapatite in finely crystallized aggregates and locally abundant phase UNK1. The crystallization of these cavity minerals was accompanied by local introduction of $\mathrm{As}^{5+}, \mathrm{Sc}^{3+}, \mathrm{Zn}^{2+}$ a $\mathrm{Cu}^{2+}$, i.e. elements, which are probably derived from altered primary sulphides, arsenides (chalcopyrite, sphalerite, arsenopyrite, tetrahedrite, tennantite) and wolframite, abundant in the apical part of the stock (Beran - Sejkora 2006).

Specific mineral association includes re-mobilized phosphates in cavities of coarse-grained quartz gangue, which are not related in their distribution to phosphate accumulations described above. Minerals of the turqouise group (chalcosiderite - turquoise), fluorapatite, minerals of the crandallite group (dominant goyazite, crandallite, waylandite and UNK11), vivianite, fluellite and wavellite are involved. Phosphates in cavities are accom- panied by fluorite, topaz and minerals of kaolinite group. The relative time of crystallization of this association is somewhat uncertain. Based on indirect indications we assume that it may be approximately coeval with crystallization of younger phosphates in corrosional cavities of phosphate accumulations.

The latest stage of phosphate formation in the Huber open pit domain (filling of corrosion cavities and re-mobilized phosphates in cavities of quartz gangue) was characterized by exceptionally high fluorine activity as well. This is indicated by crystallization of the youngest fluorapatites and the abundant occurrence of a F-analogue of perhamite - mineral UNK1 in cavities of phosphate accumulations, or the high $\mathrm{F}$ content in minerals of the crandallite group and locally rich occurrence of fluellite in quartz gangue cavities. Elevated contents of $\mathrm{Sr}$, derived probably from dissolution of older generations of fluorapatite containing minor $\mathrm{Sr}$, are interesting. Sr-dominated goyazite is the most common species among minerals of the crandallite group and $\mathrm{Sr}$ is also important as a regular minor element in $U N K 1$.

\section{$5^{\text {th }}$ level of the Huber shaft}

The mineral association of phosphates at the $5^{\text {th }}$ level of the Huber shaft evolved (Fig. 91) in the environment of greisenized granite stock with local development of extensive horizons of compact quartz, c. $200 \mathrm{~m}$ below contact with overlying gneisses and at about a similar depth below the present land surface.

The primary phosphates occur as large aggregates of triplite and compact fluorapatite. During the early hydrothermal stage triplite was extensively replaced by younger fluorapatite. This fluorapatite (together with a part of primary fluorapatite) was extensively selectively replaced by isokite, replacement of triplite by isokite was not observed. Subsequent extensive replacement of both generations of fluorapatite, and less commonly triplite, by 
Fig. 91 Schematic presentation of the evolution of phosphate mineral associations at the $5^{\text {th }}$ level of the Huber shaft, Krásno.

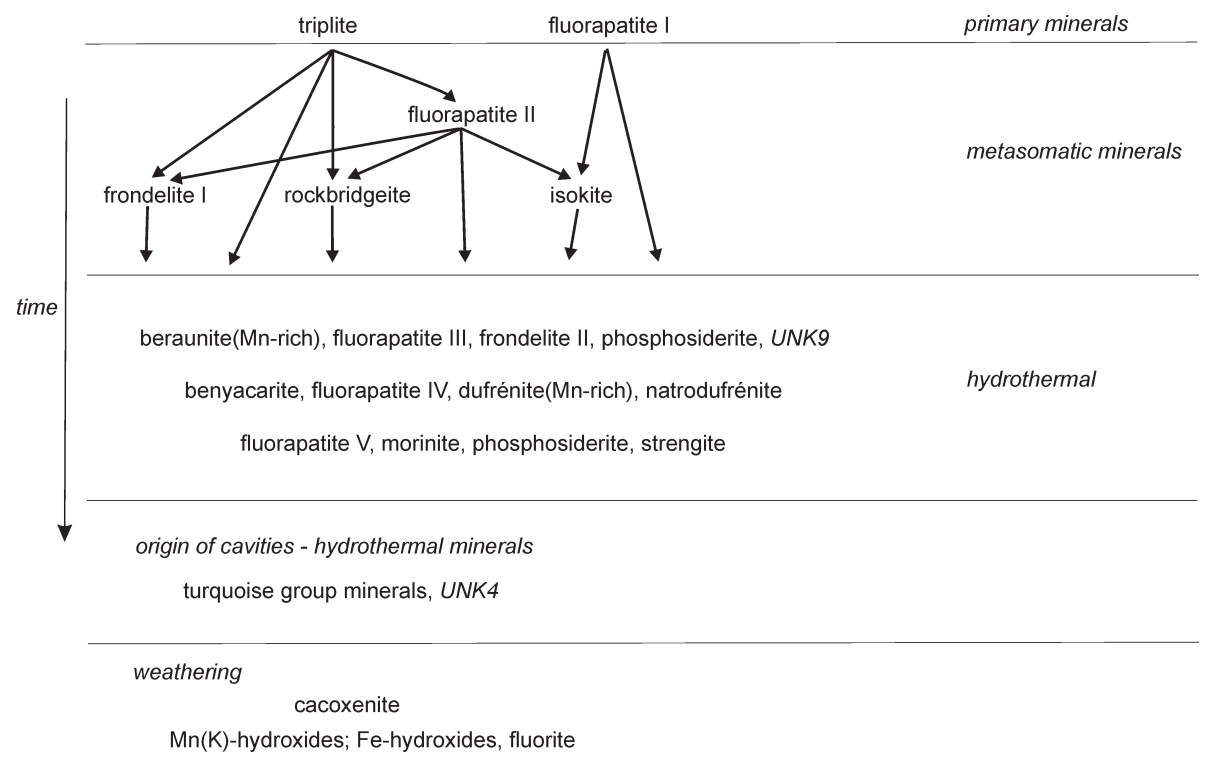

minerals of the rockbridgeite - frondelite (I) series resulted in formation of their large accumulations, up to $10 \mathrm{~cm}$ in size. Formation of abundant isokite aggregates during this stage indicates significant import of $\mathrm{Mg}$ (probably from rocks of the metamorphic envelope - see above). Fluorine contents in triplite, fluorapatite and isokite and their abundance indicate F-rich environment. Formation of minerals of the rockbridgeite - frondelite series points to locally significant import of Fe, $\mathrm{Mn}$ and some $\mathrm{Zn}$.

During a later hydrothermal stage (or several overlapping stages) extensive alteration of Fe-Mn phosphates proceeded, whereas older triplite, fluorapatite and isokite were altered only exceptionally. The aggregates of FeMn phosphates (predominating frondelite I and rare rockbridgeite) were first replaced by frondelite II, UNK9, Mn-rich beraunite and to a lesser extent by fluorapatite and phosphosiderite. This stage was followed by formation of Mn-rich dufrénite, natrodufrénite, fluorapatite and rare benyacarite crystals in small cavities. During the latest stage aggregates of abundant phosphosiderite formed in addition to fluorapatite, less common morinite and strengite as one of the latest phases.

The hydrothermal phosphates contain remarkably increased $\mathrm{Mn}$, frondelite is more abundant than rockbridgeite, and UNK9, Mn-rich beraunite and dufréniterelated minerals occur, all indicating environment with a high $\mathrm{Mn} / \mathrm{Fe}$ ratio. This high ratio is probably one of the general geochemical characteristics of the Huber stock. The increased Mn content in the studied apatites is remarkable. The enrichment in $\mathrm{Mn}$ is even higher in the nearby Schnöd stock as indicated by the occurrences of carpholite, rodochrosite, hübnerite etc.

During a following stage, dissolution of compact fluorapatite and its removal, accompanied by partial removal of isokite, resulted in formation of corrosion cavities 5$10 \mathrm{~cm}$ across, within the phosphate accumulations. However, the extent of this process and abundance of corro- sion cavities at the $5^{\text {th }}$ level of the Huber shaft is significantly lower, relative to the situation in the Huber open pit. Minerals of the turquoise group (chalcosiderite and turquoise), fluorapatite and local rich aggregates of UNK4 crystallized in the cavities.

The environment during all stages of evolution of the phosphate accumulations was rich in fluorine. This is indicated by several successive generations of fluorapatite, the presence of F-rich morinite, UNK4 and by abundance of small fluorite aggregates in the mineral associations.

Acknowledgements. We thank the following colleagues for their cooperation - Jiří Litochleb (National Museum, Prague), František Veselovský and Stanislav Vrána (Czech Geological Survey, Prague), Miroslava Novotná and Jana Ederová (Institute of Chemical Engineering, Prague), Jakub Plášil, Martin Mazuch and Oldřich Fatka (Faculty of Science, Charles University, Prague) and Jaromír Tvrdý and Zdeněk Mach (Karlovy Vary).

This work was supported by Grants from the Ministery of Culture of the Czech Republic (Project MK00002327201) and the Granting Agency of the Czech Republic (Grant No. 205/03/D004).

Submitted June 9, 2006

\section{References}

Anthony, J. W. - Bideaux, R. A. - Bladh, K. W. - Nichols, M. C. (2000): Handbook of Mineralogy. Volume IV. Arsenates, Phosphates, Vanadates. Mineral Data Publishing, Tucson, 680 pp.

Baldwin, J. R. - Hill, P. G. - von Knorring, O. - Oliver, G. J. H. (2000): Exotic aluminium phosphates, natromontebrasite, brazilianite, goyazite, gorceixite and crandallite from rare-element pegmatites in Namibia. - Min. Mag., 64: 1147-1164.

Bayliss, P. (1986): X-ray powder data for nissonite and waylandite. - Powder Diffr., 1: 331-333.

Beran, P. (1999): Minerals of tin-tungsten deposits in the Slavkovský les area. - Regional Museum and Library in Sokolov, Sokolov, 287 pp., (in Czech). 
Beran, P. - Sejkora, J. (2006): The Krásno Sn-W ore district near Horní Slavkov: mining history, topographical, geological and mineralogical characteristics. - J. Czech Geol. Soc., 51: 3-42

Blass, G. - Witternn, A. (1994): Neue Mineralien von der Rubocin Mine bei Karibib, Namibia. - Mineral. Welt, 5:25-31.

Borensztajn, J. (1966): Structure cristallines de la metavariscite et de la metastrengite. - Bull. Soc. Franc. Min. Crist., 89: 428-438.

Clark, A. M. - Couper, A.G. - Embrey, P. G. - Fejer, E. E. (1986): Waylandite: new data, from an occurrence in Cornwall, with a note of agnesite. - Miner. Mag., 50: 731-733.

Chen, N. - Pan, Y. - Weil, J., A. (2002): Electron paramagnetic resonance spectroscopic study of synthetic fluorapatite: Part I. Local structural environment and substitution mechanism of $\mathrm{Gd}^{3+}$ at the $\mathrm{Ca} 2$ site. Amer. Mineral., 87: 37-46.

Chopin, C.-Armbruster, T. - Baronnet, A. - Grew, E. S. (2004): Polytypism in the wagnerite-triplite group, $(\mathrm{Mg}, \mathrm{Fe}, \mathrm{Mn})_{2} \mathrm{PO}_{4}(\mathrm{~F}, \mathrm{OH})$, and discreditation of magniotriplite. $-5^{\text {th }}$ International conference "Mineralogy and Museums", Paris. Collected abstracts.

Deans, T. - McConnell, J. D. C. (1955): Isokite, a new mineral from Nothern Rhodesia. - Miner. Mag., 30: 681-691.

Demartin, F. - Gay, H. D. - Gramaccioli, C. M. - Pilati, T. (1997): Benyacarite, a new titanium-bearing phosphate mineral species from Cerro Blanco, Argentina. - Can. Mineral., 35: 707-712.

Demartin, F. - Pilati, T. - Gay, H. D. - Gramaccioli, C. M. (1993): The crystal structure of a mineral related to paulkerrite. - Zeit. Krist., 208: 57-71.

Dick, $S$. Zeiske, T., (1997): Leucophosphite $\mathrm{K}\left[\mathrm{Fe}_{2}\left(\mathrm{PO}_{4}\right)_{2}(\mathrm{OH})\left(\mathrm{H}_{2} \mathrm{O}\right)\right] . \mathrm{H}_{2} \mathrm{O}$ : Hydrogen Bonding and Structural Relationships. - Journ. Solid State Chemistry, 133: 508-515.

di Cossato, M. F. Y. - Orlandi, P. - Pasero, M. (1989): Manganese-bearing beraunite from Mangualde, Portugal: mineral data and structure refinement. - Can. Mineral., 27: 441-446.

Fanfani, L. - Zanazzi, P. F. (1966): La struttura cristallina della metastrengite. - Atti della Accademia Nazionale dei Lincei, Classe di Scienze Fisiche, Matematiche e Naturali, Rendiconti, 8, 40: 889-889.

- (1967): The crystal structure of beraunite. - Acta Cryst. 22: 173-181.

Farmer, V. C. (ed.) (1974): The infrared spectra of minerals. - Mineralogical Society Monograph., 4: 1-539.

Fischer, J. D. (1957): Isokite and triplite from Bohemia. - Miner. Mag., 31: 587-602.

- (1960): Morinite-apatite-whitlockite. - Amer. Mineral., 45: 645-667.

Fischer, J. D. - Runner, Ju. J. (1958): Morinite from the Black Hills. Amer. Mineral., 43: 585-594.

Fontan, F. - Pillard, F. - Permingeat, F. (1982): La natrodufrénite $(\mathrm{Na}, \square)\left(\mathrm{Fe}^{+++}, \mathrm{Fe}^{++}\right)\left(\mathrm{Fe}^{+++}, \mathrm{Al}\right)_{5}\left(\mathrm{PO}_{4}\right)_{4}(\mathrm{OH})_{6} .2 \mathrm{H}_{2} \mathrm{O}$, une nouvelle espece minérale du groupe de la dufrenite. - Bull. Minéral., 105: 321-326.

Foord, E. E. - Taggart, J. E. Jr. (1998): A reexamination of the turquoise group: the mineral aheylite, planerite (redefined), turquoise and coeruleolactite. - Miner. Mag., 62: 93-111.

Fransolet, A.-M. - Oustriere, P. - Fontan, F. - Pillard, F. (1984): La mantiennéite, une nouvelle espece minérale du gisement de vivianite d'Anloua, Cameroun. - Bull. Minéral., 107: 737-744.

Guy, B. B. - Jeffrey, G. A (1966): The crystal structure of fluellite, $\mathrm{Al}_{2} \mathrm{PO}_{4} \mathrm{~F}_{2}(\mathrm{OH})\left(\mathrm{H}_{2} \mathrm{O}\right)_{7}$. - Amer. Mineral., 51: 1579-1592.

Hawthorne, F. C. (1979): The crystal structure of morinite. - Can. Mineral., 17: 93-102.

Hey, M. H. - Milton, C. - Dwornik, E. J. (1982): Eggonite (kolbeckite, sterrettite), $\mathrm{ScPO}_{4} .2 \mathrm{H}_{2} \mathrm{O}$. - Mineral. Mag., 46: 493-497.

Hochleitner, R. - Fehr, K. T. (2005): Isokite, $\mathrm{CaMg}\left[\mathrm{F} \mid \mathrm{PO}_{4}\right]$, from Senhora de Assunçao, Portugal: new find and new data. - N. Jb. Miner. Abh., 182: $103-108$.

Hughes, J. M. - Ertl, A. - Bernhardt, H., J. -Rossman, R. - Rakovan, J. (2004): Mn-rich fluorapatite from Austria: Crystal structure, chemical analysis, and spectroscopic investigations. - Amer. Mineral., 89: 629-632.

Isaacs, M. A., Peacor, D. P. (1981): Panasqueiraite, a new mineral: the OH-equivalent of isokite. Can. Mineral., 19: 389-392.
Jaffe, H. W. - Hall, L. M. - Evans, H. T. (1992): Wagnerite and isokite from Benson Mines, west-central Adirondack Highlands, New York. - Miner. Mag., 56: 227-233.

Knorring von, O. - Lehtinen, M. - Sahama, T. G. (1977): Burangaite, a new phosphate mineral from Rwanda. - Bull. Geol. Soc. Finland, 49:33-36.

Knorring von, O. - Mrose, M. E. (1963): Westgrenite and waylandite, two new bismuth minerals from Uganda. - Geol. Soc. Amer. Spec. Paper 73, 256A.

Korbel, P. (1991): Supergene minerals from Horní Slavkov. - Sbor. Nár. Muz. (Praha); B47: 1-24.

Kydryashova, V. I. - Rozhdestvenskaya, I. V. (1991): New minerals XLV. - Zap. Vses. Mineral. Obshch., 120: 100-115 - reference of book Chesnokov, B. V. - Vilisov, V. A. - Polakov, V. O. - Bushmakin, A. F.: Mineraly i mineralnoe syre gorno-promyshlennykh rajonov Urala; see also-Vasil'ev, E., Chesnokov, B. (1991): Institute of the Earth's crust, Lermontov, Irkutsk, Russia, private communication in ICDD card No. 44-1404.

Leroy, N. - Bres, E. (2001): Structure and substitutions in fluorapatite. European Cells and Materials, 2: 36-48.

Lindberg, M. L. (1949): Frondelite and frondelite-rockbridgeite series. Amer. Mineral., 34: 541-549.

- (1957): Leucophosphite from the Sapucaia pegmatite mine, Minas Gerais, Brazil. - Amer. Mineral., 42: 214-221.

Lindberg, M. L. - Frondel, C. (1950): Zincian rockbridgeite. - Amer. Mineral., 35: 1028-1034.

Lottermoser, B. G. - Lu, J. (1997): Petrogenesis of rare-element pegmatites in the Olary Block, South Australia, part 1. Mineralogy and chemical evolution. - Mineral. Petrol., 59: 1-19.

Mach, Z. (1979): Chalkosiderite and Ba-pharmacosiderite from Krásno near Horní Slavkov - a find report. - Čas. Mineral. Geol., 79: 90-91, (in Czech).

Marincea, Ş. - Dumitras, D. - Gibert, R. (2002): Tinsleyite in the "dry" Cioclovina Cave (Sureanu Mountains, Romania): the second occurrence. - Eur. J. Mineral., 14: 157-164.

McKie, D. (1962): Goayzite and florencite from two African carbonatites. - Miner. Mag. 33: 281-297.

Medrano, M. D. - Piper, D. Z. (1997): Fe-Ca-phosphate, Fe-silicate, and Mn-oxide minerals in concretion fron the Monerey Formation. Chemical Geology, 138, 9-23.

Moore, P. B. (1970): Crystal chemistry of the basic iron phosphates. Amer. Mineral., 55: 135-169.

- (1972): Octahedral tetramer in the crystal structure of leucophosphite, $\mathrm{K}_{2}\left[\mathrm{Fe}_{4}^{3+}(\mathrm{OH})_{2}\left(\mathrm{H}_{2} \mathrm{O}\right)_{2}\left(\mathrm{PO}_{4}\right)_{4}\right] .2 \mathrm{H}_{2} \mathrm{O}$. - Amer. Mineral., 57, 397-410.

Moore, P. B. (1982): Pegmatite minerals of P(V) and B(III). - In: Černý, P. ed.: Granitic pegmatite in science and industry. - MAC Short course, 8: 267-291.

Moore, P. B. - Kampf, A. R. (1992): Beraunite: refinement, comparative crystal chemistry, and selected bond valences. - Zeit. Krist., 201: 263-281.

Mrázek, Z. (1981): Crandallite and mixite from Horní Slavkov. - Sbor. Vys. Šk. chem.-technol., mineral., G 20: 43-47, (in Czech).

Novák, F. -Jansa, J. - Prachař. I. (1994): Classification and nomenclature of alunite - jarosite and related mineral groups. - Věst. Čes. geol. úst., 69: 51-58.

Novák, F. - Pauliš, P. - Süsser, C. (2001): Chemical composition of crandallite, goyazite and waylandite from Krásno near Horní Slavkov. - Bull. mineral. - petrolog. Odd. Nár. Muz. (Praha), 9: 230-234, (in Czech).

Ondruš, P. (1993): ZDS - A computer program for analysis of X-ray powder diffraction patterns. - Materials Science Forum, 133-136: 297300, EPDIC-2. Enchede.

Ondruš, P. - Skála, R. (1997): New quasi-empirical channel Search/Match algorithm for ICDD PDF2 Database: A tool for qualitative phase analysis integrated in the ZDS-System software package for X-ray powder diffraction analysis - Fifth European Powder Diffraction Conference EPDIC-5, 193. Parma. 
Palache, Ch. - Berman, H. - Frondel, C. (1951) Dana's System of Mineralogy. $7^{\text {th }}$ edition, vol. II, J. Wiley and Sons, $920 \mathrm{pp}$.

Peacor, D. R. - Dunn, P. J. - Simmons, W. B. (1984): Paulkerrite, a new titanium phosphate from Arizona. - Min. Record: 303-306.

Pe-Piper, G. - Dolansky, L. M. (2005): Early diagenetic origin of Al phosphate-sulfate minerals (woodhouseite and crandallite series) in terrestrial sandstones, Nova Scotia, Canada. - Amer. Mineral., 90: 1434-1441.

Pollmann, H. - Witzke, T. - Keck, E. - Steins, M. - Friese, K. - Goske, J. (1998): Martin-Luther-Univ. Halle, Wittenberg, Germany; ICDD Grant-in-Aid (ICDD card 50-1552).

Pouchou, J. L. - Pichoir, F. (1985): "PAP" procedure for improved quantitative microanalysis. - Microbeam Analysis, 20: 104-105.

Povarennykh, A. S. (1972): Crystal Chemical Classification of Minerals. (English Edition). Plenum Press, New York. pp 349.

Puziewicz, J. - Johannes, W. (1988): Phase equilibria and composition of $\mathrm{Fe}-\mathrm{Mg}-\mathrm{Al}$ minerals and melts in water-saturated peraluminous granitic system. - Contr. Miner. Petr., 100: 156-168.

- (1990): Experimental study of biotite-bearing granitic system under water-saturated and water-unsaturated conditions. - Contr. Miner. Petr., 104: 397-406.

Raudsep, M. (1995): Recent advances in the electron-probe analysis of minerals for the light elements. - Can. Mineral., 33: 203-218.

Roda-Robles, E. - Fontan, F. - Pesquera Pérez, A. - Keller, P. (1998): The Fe-Mn phosphate associations from the Pinilla de Fermoselle pegmatite, Zamora, Spain: occurrence of kryzhanovskite and natrodufrénite. - Eur. J. Mineral., 10: 155-167.

Rodríguez-Carvajal, J. (2005): Computer Program FullProf, ver. December 2005. - Laboratoire Leon Bril-louin (CEA-CNRS), France.

Scott, K. M. (1987): Solid solution in, and classification of, gossan-derived members of the alunite-jarosite family, northwest Queensland, Australia. - Amer. Mineral., 72: 178-187.

Sejkora, J. - Škoda, R. - Ondruš, P. (2006d): New naturally occurring mineral phases from the area Krásno - Horní Slavkov, western
Bohemia, Czech Republic. - Journ. Czech Geol. Soc., 51: 159188

Selway, J. B.-Cooper, M. A. - Hawthorne, F. C. (1997): Refinement of the crystal structure of burangaite. - Can. Mineral., 35:15151522 .

Schwab, R. G. - Pimpl, T. - Schukow, H. - Stolle, A. - Breitinger, D. K. (2004): Compounds of the crandallite-type: Synthesis, properties and thermodynamic data of pure crandallite and woodhouseite. $-\mathrm{N}$. Jb. Miner. Mh., 385-409.

Tadini, C. (1981): Magniotriplite: its crystal structure and relation to the triplite-triploidite group. - Bull. Soc. Franc., Miner. Crist., 104: 677680.

Taxer, K. - Bartl, H. (2004): On the dimorphy between the variscite and clinovariscite group: refined finestructural relationship of strengite and clinostrengite, $\mathrm{Fe}\left(\mathrm{PO}_{4}\right)$. 2( $\left.\mathrm{H}_{2} \mathrm{O}\right)$. - Crystal Research Technol., 39: 1080-1088.

Waldrop, L. (1968): The crystal structure of triplite. - Naturwissenschaften, 55: 178.

- (1969): Study of minerals with the formula type $\mathrm{ABXO}_{4}(\mathrm{Z})$, with special attention to the crystal structures of the triplite-triploidite group. - PhD. thesis, Massachusetts Institute of Technology. $136 \mathrm{pp}$.

Wambeke van, L. (1975): La zairite, un nouveau minéral appartenant à la série de la crandallite. - Bull. Soc. fr. Minéral., 98: 351-353.

Wilson, M. J. - Bain., D. C. (1976): Occurence of leucophosphite in a soil from Elephant Island, Brithis Antarctic Territory. - Amer. Mineral., 61, 1027-1028.

- (1986): Sphenicsidite, a new phosphate mineral from Elephant Island, British Antarctic Territory. - Miner. Mag., 50, 291-293.

Yakubovich, O. V. - Simonov, M. A. - Matvienko, E. N. - Belov, N. V. (1978): The crystal structure of the synthetic finite Fe-term of the series triplite - zwieselite $\mathrm{Fe}_{2}\left(\mathrm{PO}_{4}\right) \mathrm{F}$. - Dokl. Akad. Nauk SSSR, 238, $576-579$.

\section{Mineralogie akumulací fosfátů oblasti Huberova pně, rudní revír Krásno, Slavkovský les, Česká republika}

Podrobný výzkum byl zaměřen na minerály fosfátových akumulací, zjištěných v povrchovém lomu na Huberově pni a na 5. patře dolu Huber v Sn-W rudním revíru Krásno, Slavkovský les (Česká republika). Na studovaných lokalitách byly zjištěny výskyty benyacaritu, beraunitu, chalkosideritu, crandallitu, dufrénitu, earlshannonitu, fosfosideritu, fluellitu, fluorapatitu, frondelitu, goyazitu, isokitu, kakoxenu, kolbeckitu, leukofosfitu, morinitu, natrodufrénitu, rockbridgeitu, strengitu, triplitu, tyrkysu, vivianitu, wavellitu, waylanditu, whitmoreitu a zwieselitu. Pro jednotlivé zjištěné minerální druhy je podána makro- i mikroskopická charakteristika, rentgenová prášková data a/nebo vypřesněné parametry základní cely a výsledky kvantitativních chemických analýz. Zjištěná data jsou podrobně diskutována v porovnání s publikovanými údaji pro jednotlivé minerální druhy.

Součástí článku je i přehled vývoje minerálních asociací fosfátů na obou studovaných lokalitách. 